\title{
Conodonts from the Upper Ordovician - Lower Silurian carbonate platform of North Greenland
}

Howard A. Armstrong

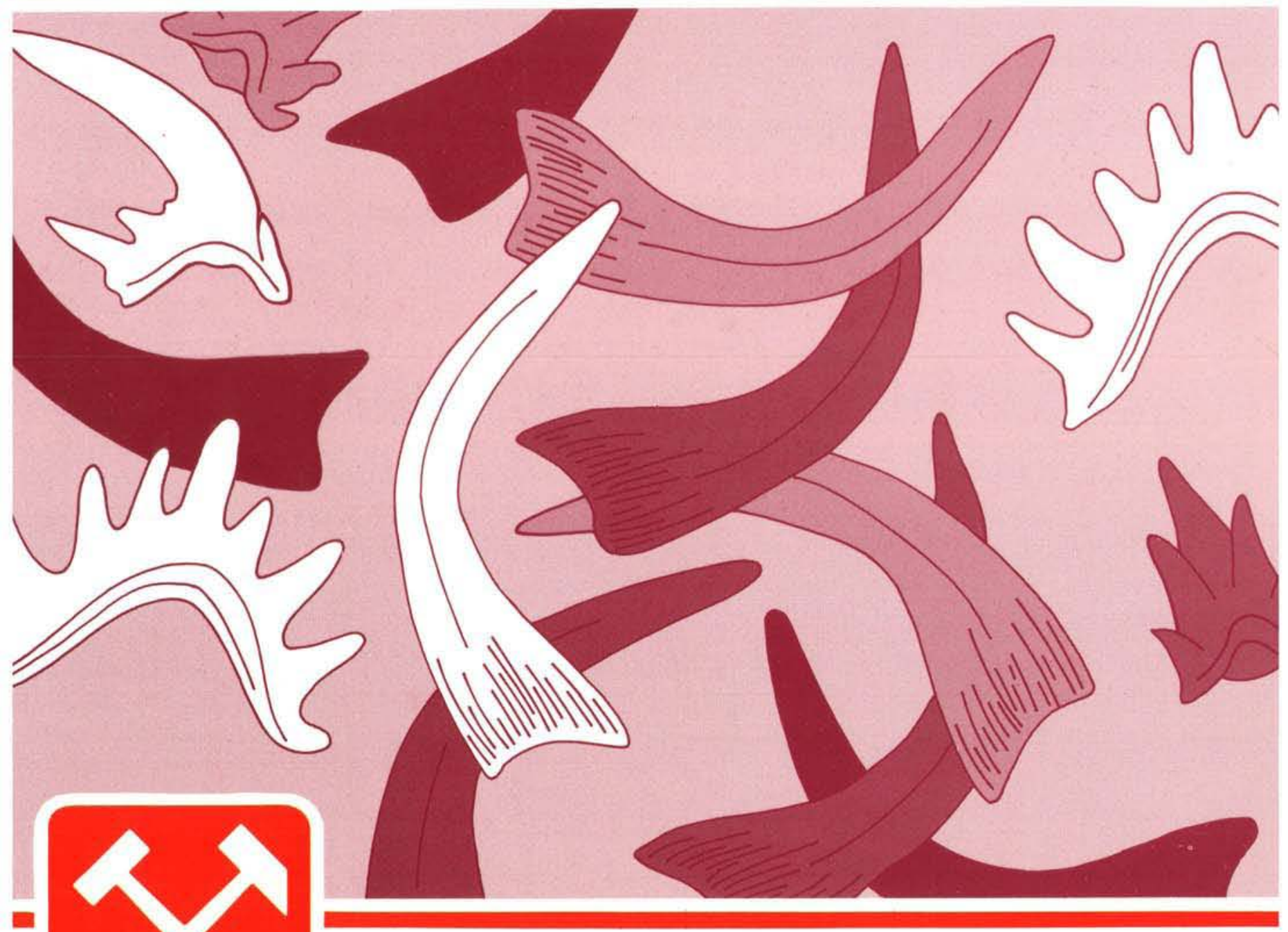

GGU Bulletin 159 
GRØNLANDS GEOLOGISKE UNDERS $\emptyset$ GELSE

Bulletin 159

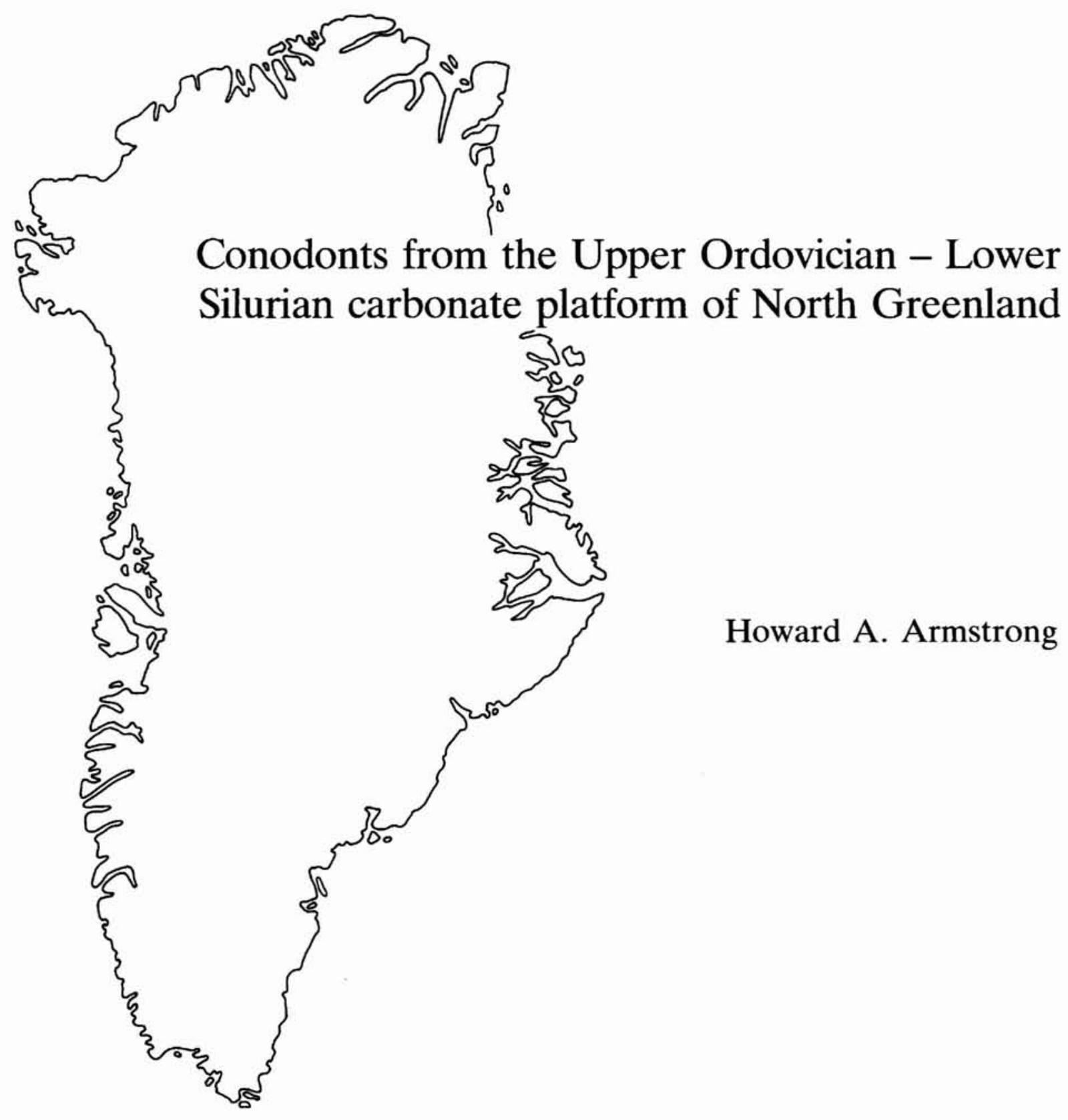


Abstract

\begin{abstract}
Samples from Upper Ordovician and Lower Silurian strata of the North Greenland carbonate platform have yielded approximately 16500 identifiable conodont elements referable to 25 multi-element genera and 71 species and subspecies. A single genus, Pseudobelodella and 17 species and subspecies are new. In addition, 8 informal groups of indeterminate species of Oulodus are described.

The Upper Ordovician conodont species can be referred to 'Fauna 12' of the American Midcontinent Province where the presence of Rhipodognathus symmetrius in the late Richmondian is typical of shallow water deposits. The Ordovician-Silurian boundary is difficult to place in this study using conodonts. New
\end{abstract}

conodont zonations are proposed for Lower Silurian shelf and slope biofacies; two new early Llandovery conodont zones are erected in the slope biofacies, the Aspelundia expansa Biozone (?earliest Rhuddanian to early Aeronian) and the Aspelundia fluegeli Biozone (early Aeronian to early Telychian). The Pterospathodus celloni Biozone is shown to be particularly valuable in the correlation of strata of late Llandovery age throughout North Greenland.

\section{Author's address:}

Department of Geology, The University, Newcastle upon Tyne NE1 7RU, England.

\section{Dansk sammendrag}

I øvre ordoviciske og nedre silure bjergarter i Nordgrønland er der fundet ca. 16500 identificerbare conodont-elementer, som kan placeres i 25 multielement slægter og 71 arter eller underarter. Der opstilles og beskrives en ny slægt, Pseudobelodella, og 17 nye arter eller underarter. Herudover beskrives 8 taxonomisk uformelle grupper af ubestemmelige arter af slægten Oulodus.

De $ø$ vre ordoviciske conodonter kan stratigrafisk sammenlignes med 'Fauna 12' fra den 'Amerikanske Midtkontinent Provins'. Her er tilstedeværelsen af Rhipodognathus symmetricus i det øverste Richmondian typisk for lavvandsaflejringer og arten antages at vise samme aflejringsmiljø for de nordgrønlandske faunaer og sedimenter. Grænsen mellem Ordovicium og Silur i Nordgrønland er vanskelig af identificere præcist på grundlag af conodonter alene.

Der defineres to nye conodont-biozoner af nedre Llandovery alder: Aspelundia expansa Zone (?tidligste Rhuddanian til tidlig Aeronian) og Aspelundia fluegeli Zone (tidlig Aeronian til tidlig Telychian). De indgår i en ny conodont-biozonering opstillet for kontinentalsokkel og -skrænt facies i Nedre Silur. Det dokumenteres, at Pterospathodus celloni Zonen kan følges over hele Nordgrønland i øvre Llandovery sedimenter og derfor er specielt velegnet til korrelation af disse lag. 


\section{Contents}

Geological setting $\ldots \ldots \ldots \ldots \ldots \ldots \ldots \ldots \ldots \ldots \ldots \ldots \ldots \ldots \ldots \ldots \ldots$

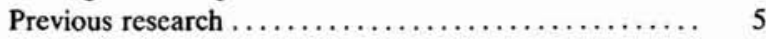

Samples and techniques $\ldots \ldots \ldots \ldots \ldots \ldots \ldots \ldots \ldots \ldots \ldots$

Lithostratigraphy and conodont biostratigraphy...... 8

Peary Land - Kronprins Christian Land ......... 8

Tures $ø$ Formation ...................... 8

Ymers Gletscher Formation .............. 9

Odins Fjord Formation $\ldots \ldots \ldots \ldots \ldots \ldots \ldots \ldots, 9$

Melville Land Member ................ 13

Bure Iskappe Member................. 13

Samuelsen $\mathbf{H} ø$ j Formation $\ldots \ldots \ldots \ldots \ldots \ldots \ldots, 13$

Peary Land Group ..................... 15

Wulff Land Formation.................. 15

Thors Fjord Member .................... 16

Lauge Koch Land Formation ............. 16

Profilfjeldet Member................. 16

J. P. Koch Fjord and Wulff Land ............. 16

J. P. Koch Fjord ........................ 16

Aleqatsiaq Fjord Formation.............. 18

Kap Ammen Member ................. 18

Store Canyon Member ................. 18

Washington Land Group................... 18

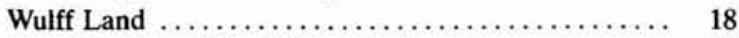

Aleqatsiaq Fjord Formation............. 18

Washington Land Group................... 19

Silurian carbonate formation $1 \ldots \ldots \ldots \ldots \ldots . \quad 19$

Silurian carbonate formation $2 \ldots \ldots \ldots \ldots \ldots . \quad 19$

Silurian carbonate formation $3 \ldots \ldots \ldots \ldots \ldots 20$

Washington Land and western Hall Land ........ 22

Morris Bugt Group ..................... 22

Aleqatsiaq Fjord Formation ............. 22

Washington Land Group.................. 22

Adams Bjerg Formation ................ 22

Petermann Halvø Formation ............... 24

Pentamerus Bjerge Formation .............. 24

Kap Godfred Hansen Formation............. 24

Bessels Fjord Formation ................ 25

Offley Island Formation $\ldots \ldots \ldots \ldots \ldots \ldots \ldots, 25$

Kap Lucie Marie Formation.............. 27

Kap Morton Formation................ 27

Kap Maynard Formation. ................. 27

Hauge Bjerge Formation ................ 27

Kap Independence Member.............. 28

Cape Tyson Member ................... 28

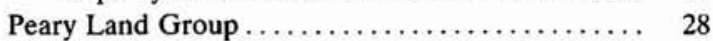

Cape Schuchert Formation ............... 28

Lafayette Bugt Formation............... 28

North Greenland conodont biozones ........... 29
Late Ordovician - middle Llandovery shelf biofa-

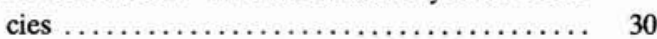

'Fauna 12' .......................... 30

'Lower Silurian Fauna' ................ 30

Early to middle Llandovery slope and outer shelf biofacies........................ 30

Late Llandovery - Pterospathodus celloni Bio-

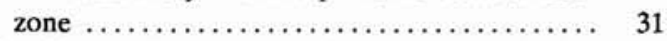

Llandovery-Wenlock boundary - Pterospathodus amorphognathoides Biozone.............. 31

Comparisons with other early Silurian conodont

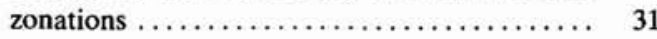

Palaeo-ecological observations............... 34

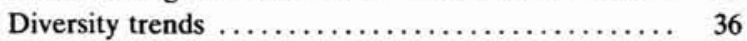

SYSTEMATIC PALAEONTOLOGY ........... 38

Conodont element terminology ........... 38

Ramiform genera ...................... 38

Coniform genera........................ 38

Silurian conodont systematic palaeontology ....... 41

Genus Apsidognathus Walliser, $1964 \ldots \ldots \ldots \ldots \ldots .41$

Apsidognathus tuberculatus tuberculatus Walliser,

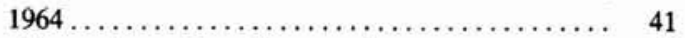

Apsidognathus tuberculatus arcticus $\mathrm{n}$. ssp....... 46

Apsidognathus n. sp.................... 47

Genus Aspelundia (Savage, 1985) .............. 49

Aspelundia expansa n. sp................ 50

Aspelundia fluegeli (Walliser, 1964) .......... 53

Aspelundia? n. sp. 1 .................... 55

Aspelundia? n. sp. A................... 55

Aspelundia? n. sp. B ................... 56

Genus Astropentagnathus Mostler, 1967 ......... 58

Astropentagnathus irregularis Mostler, $1967 \ldots \ldots . \quad 58$

Astropentagnathus irregularis irregularis Mostler, 1967

Astropentagnathus irregularis n. ssp............. 60

Genus Aulacognathus Mostler, 1967............ 62 Aulacognathus bullatus (Nicoll \& Rexroad, 1969).. 62 Aulacognathus latus (Nicoll \& Rexroad, 1969)..... 65

Genus Belodella Ethington, $1959 \ldots \ldots \ldots \ldots \ldots \ldots .65$

Belodella cooperi $\mathrm{n} . \mathrm{sp} . \ldots \ldots \ldots \ldots \ldots \ldots \ldots \ldots \ldots 6 . \ldots \ldots$

Genus Carniodus Walliser, $1964 \ldots \ldots \ldots \ldots \ldots \ldots .68$

Carniodus carnulus Walliser, $1964 \ldots \ldots \ldots \ldots \ldots 68$

Genus Dapsilodus Cooper, $1976 \ldots \ldots \ldots \ldots \ldots \ldots \ldots .70$

Dapsilodus obliquicostatus (Branson \& Mehl, 1933a) ....................... 70

Genus Decoriconus Cooper, 1975 ............. 71

Decoriconus fragilis Branson \& Mehl, 1933a ..... 71 
Genus Dentacodina Wang, 1980

Dentacodina aff. $D$. dubia (Rhodes, 1953) ........

Genus Distomodus (Branson \& Branson, 1947)......

Distomodus staurognathoides (Walliser, 1964) .....

Distomodus n. sp. .......................

Distomodus? sp.

Genus Kockelella Walliser, 1964

Kockelella manitoulinensis (Pollock, Rexroad \&

Nicoll, 1970)

Kockelella cf. K. ranuliformis (Walliser, 1964).....

Kockelella aff. K. patula (Walliser, 1964) ........

Genus Oulodus Branson \& Mehl, 1933b...........

Oulodus sp. A Aldridge, $1979 \ldots \ldots \ldots \ldots \ldots \ldots$

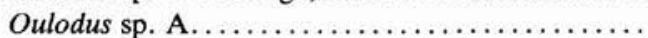

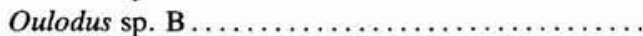

Oulodus spp. indet. group $1 \ldots \ldots \ldots \ldots \ldots \ldots$

Oulodus spp. indet. group $2 \ldots \ldots \ldots \ldots \ldots \ldots \ldots$

Oulodus spp. indet. group $3 \ldots \ldots \ldots \ldots \ldots \ldots \ldots$

Oulodus spp. indet. group $4 \ldots \ldots \ldots \ldots \ldots \ldots$

Oulodus spp. indet. group $5 \ldots \ldots \ldots \ldots \ldots \ldots$

Oulodus spp. indet. group $6 \ldots \ldots \ldots \ldots \ldots \ldots$

Oulodus spp. indet. group $7 \ldots \ldots \ldots \ldots \ldots \ldots$

Oulodus spp. indet. group 8 .

Genus Ozarkodina Branson \& Mehl, 1933a .........

Ozarkodina broenlundi Aldridge, 1979 ..........

Ozarkodina excavata (Branson \& Mehl, 1933a)....

Ozarkodina aff. O. gulletensis? (Aldridge, 1972)...

Ozarkodina cf. O. hadra (Nicoll \& Rexroad, 1969)

Ozarkodina hassi (Pollock, Rexroad \& Nicoll, 1970)

Ozarkodina aff. O. hassi (Pollock, Rexroad \&

Nicoll, 1970) .

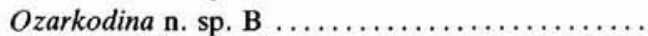

Ozarkodina n. sp. C ..................

Ozarkodina n. sp. D . . . . . . . . . . . . . . 98

Ozarkodina n. sp. E . . . . . . . . . . . . . . . . . 98

Genus Panderodus Ethington ................ 100

Panderodus cf. $P$. feulneri (Glenister, 1957) ...... 100

Panderodus greenlandensis $\mathrm{n}$. sp. .............. 102

Panderodus recurvatus (Rhodes, 1953) .......... 104

Panderodus spp. aff. P. recurvatus Rhodes, 1953. . . 107

Panderodus aff. P. spasovi Drygant, 1974c ....... 107

Panderodus unicostatus (Branson \& Mehl, 1933a). . 108

Panderodus aff. P. unicostatus (Branson \& Mehl, 1933a)

Panderodus sp. A.................... 110
Panderodus sp. B ..................... 110

Panderodus sp. C........................ 110

Panderodus sp. D........................ 111

Genus Pseudobelodella $\mathrm{n}$. gen. ................ 111

Pseudobelodella silurica $\mathrm{n}$. gen. n. sp.......... 111

Genus Pseudooneotodus Drygant, 1974c.......... 112

Pseudooneotodus cf. P. beckmanni (Bischoff \& Sannemann, 1958)...................... 112

Pseudooneotodus bicornis Drygant, 1974c....... 114

Pseudooneotodus tricornis Drygant, 1974c ....... 114

Pseudooneotodus n. sp.................... 114

Genus Pterospathodus Walliser, $1964 \ldots \ldots \ldots \ldots \ldots .115$

Pterospathodus amorphognatoides (Walliser, 1964) . 115

Pterospathodus celloni (Walliser, 1964) .......... 118

Pterospathodus pennatus Walliser, 1964 .......... 119

Pterospathodus pennatus pennatus Walliser, 1964 .. 119

Pterospathodus pennatus rhodesi (Savage, 1985) . . 120

Genus Walliserodus Serpagli, $1967 \ldots \ldots \ldots \ldots \ldots \ldots 122$

Walliserodus bicostatus (Branson \& Mehl, 1933a) .. 122

Walliserodus curvatus (Branson \& Branson, 1947) . 124

Walliserodus cf. W. sancticlairi Cooper, 1976 ..... 126

Ordovician conodont systematic palaeontology ..... 127

Genus Aphelognathus Branson, Mehl \& Branson,

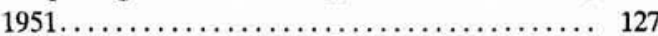

Aphelognathus pyramidalis (Branson, Mehl \& Branson, 1951) ..................... 127

Aphelognathus sp. ..................... 128

Genus Belodina Ethington, 1959............. 128

Belodina aff. B. confluens Sweet, 1979 ......... 128

Genus Drepanoistodus Lindström, 1971 .......... 130

Drepanoistodus suberectus (Branson \& Mehl, 1933b) ....................... 130

Genus Plegagnathus Ethington \& Furnish, 1959 .... 130

Plegagnathus dartoni Stone \& Furnish, 1959..... . 130

Genus Pristognathus Stone \& Furnish, 1959 ........ 131

Pristognathus bighornensis Stone \& Furnish, 1959.. 131

Genus Pseudobelodina Sweet, 1979 ............. 131

Pseudobelodina dispansa (Glenister, 1957) ....... 131

Pseudobelodina vulgaris vulgaris Sweet, 1979..... 131

Pseudobelodina sp......................... 132

Genus Rhipidognathus Branson, Mehl \& Branson,

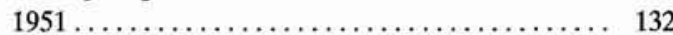

Rhipidognathus symmetricus Branson, Mehl \&

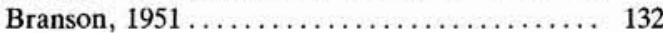

Acknowledgements ...................... 134

References........................... 135 


\section{Geological setting}

The Franklinian Basin of North Greenland represents the continuation of a geological terrane extending from Alaska through the Canadian Arctic Archipelago and Ellesmere Island into North Greenland. During the late Ordovician and early Silurian the southern margin of the basin was rimmed by an extensive carbonate platform (fig.1) with the platform margin forming a pronounced scarp-like feature. North of the scarp, slope and deep-water trough environments received clastic sediments (cf. Higgins et al., in press). The trough expanded southwards during the late Llandovery, drowning most of the carbonate platform; only isolated mound complexes survived into the early Wenlock in the Peary Land - Kronprins Christian Land area and into the late Silurian in western North Greenland.

Carbonate platform deposits of this period are assigned to the Morris Bugt and Washington Land Groups originally described in western North Greenland (Peel \& Hurst, 1980; Hurst, 1980b) but recently extended to include formations outcropping in central and eastern North Greenland (Smith et al., 1989; Sønderholm \& Harland, unpublished) (fig. 2). Slope and deep-water trough deposits are placed within the Peary Land Group (Hurst, 1980b; Hurst \& Surlyk, 1982; Larsen \& Escher, 1985, 1987).

\section{Previous research}

Conodont studies in the Arctic are as yet in their infancy. Scattered data are available, mainly from Ordovician to Devonian collections, but many reports are of a biostratigraphical nature with few taxonomic studies. A series of publications dealing with Ordovician conodont biostratigraphy has appeared as a result of regional mapping programmes in the Canadian Arctic (e.g. Barnes, 1974, 1977; Barnes et al., 1974; Brideaux et al., 1975; McGill, 1974; Mayr et al., 1978, 1980; Morrow, 1973; Tipnis \& Cecile, 1980) while an unpublished study by Mirza (1976) dealt taxonomically and biostratigraphically with sections of late Ordovician to late Silurian age from Ellesmere Island. Overshine \& Webster (1970), Savage (1985) have recorded Silurian conodonts from Alaska.

Ordovician faunas have been described from the Northwest territories, Canada by Tipnis et al. 1978 and McCracken \& Nowlan (1984). An Ordovician-Silurian boundary correlation using graptolites and conodonts for the northern Yukon was published by Lenz \& McCracken (1982); Norford \& Orchard (1983) and Over \& Chatterton (1987) described Llandovery conodonts and graptolites from the Mackenzie Mountains, Northwest Territories, Canada.

Records of conodonts from the Ordovician in Greenland include Aldridge (1982) who described a new ge- nus, Besselodus arcticus, from the Aleqatsiaq Fjord Formation of the Morris Bugt Group in Washington Land. The conodont biostratigraphy of the Morris Bugt Group is described by Smith et al. (1989). Stouge $(1977,1978)$ and Stouge et al. (1985) recorded faunas from the Lower Ordovician of Washington Land and East Greenland, while Stouge \& Peel (1979) described Ordovician conodonts from southern West Greenland. Miller \& Kurtz (1979) and Kurtz \& Miller (1981) noted the occurrence of early Ordovician faunas in East Greenland. Smith (1985) has monographed Ordovician conodont faunas from North and East Greenland. Smith \& Peel (1986), Ineson et al. (1986), Peel \& Smith (1988) and Fortey \& Peel (1989, in press) documented small Ordovician faunas from eastern North Greenland.

Aldridge (1979) and Stouge \& Stouge (1985) described small conodont faunas from the Silurian of Peary Land and Hall Land respectively. Stratigraphic reports by Hurst $(1980$ b , 1984) include unpublished conodont records supplied by $\mathrm{R}$. J. Aldridge and $\mathrm{H}$. A. Armstrong (University of Nottingham) largely summarised in Aldridge \& Armstrong (1982).

The present monograph is based on a study of late Ordovician and early Silurian conodonts from throughout North Greenland contained in an unpublished Ph.D. thesis (Armstrong, 1983). The concentration of 


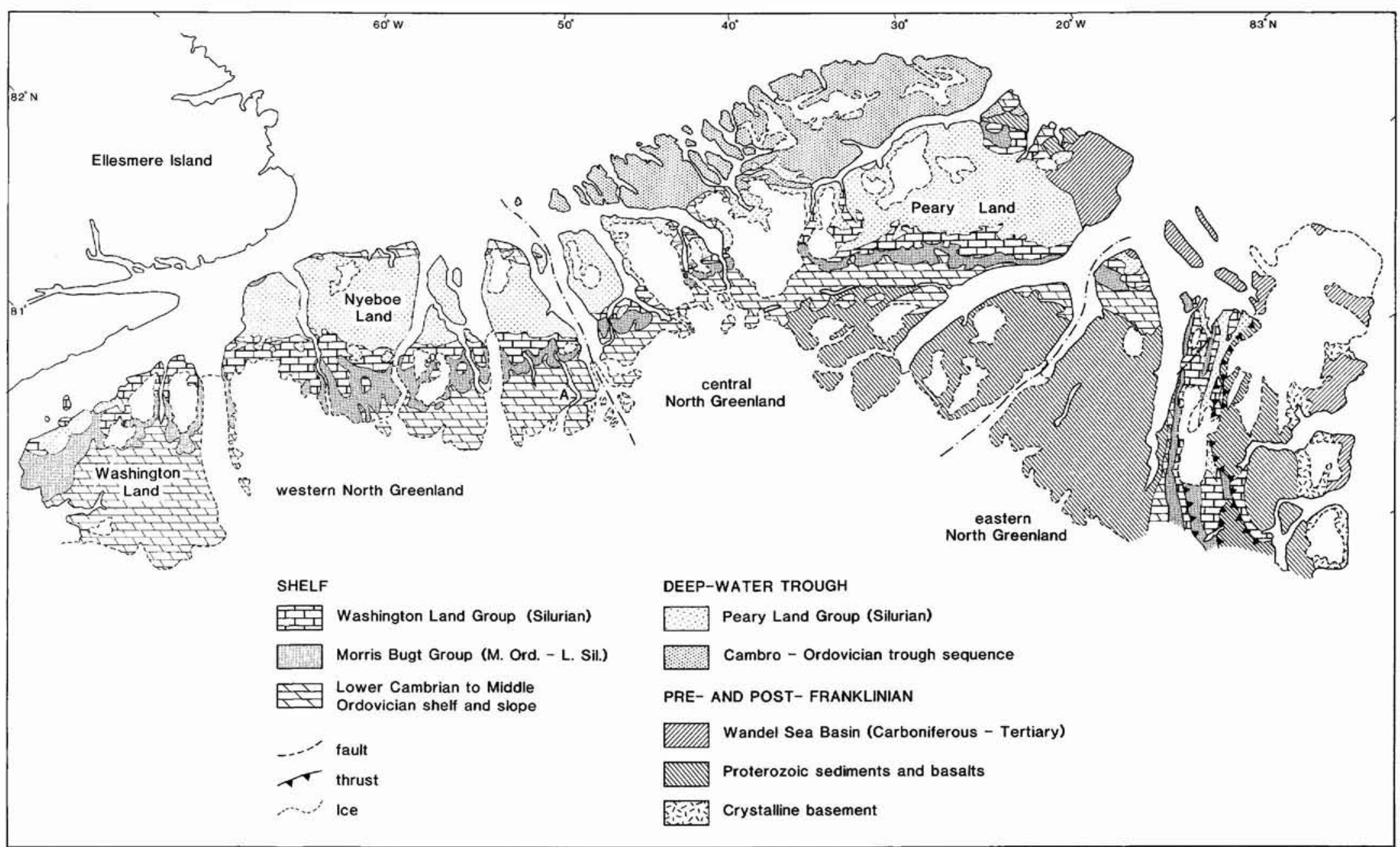

Fig. 1. Simplified geological map of Franklinian Basin sediments in North Greenland. A, 'Apollo Sø' (adapted from Smith et al., 1989). 


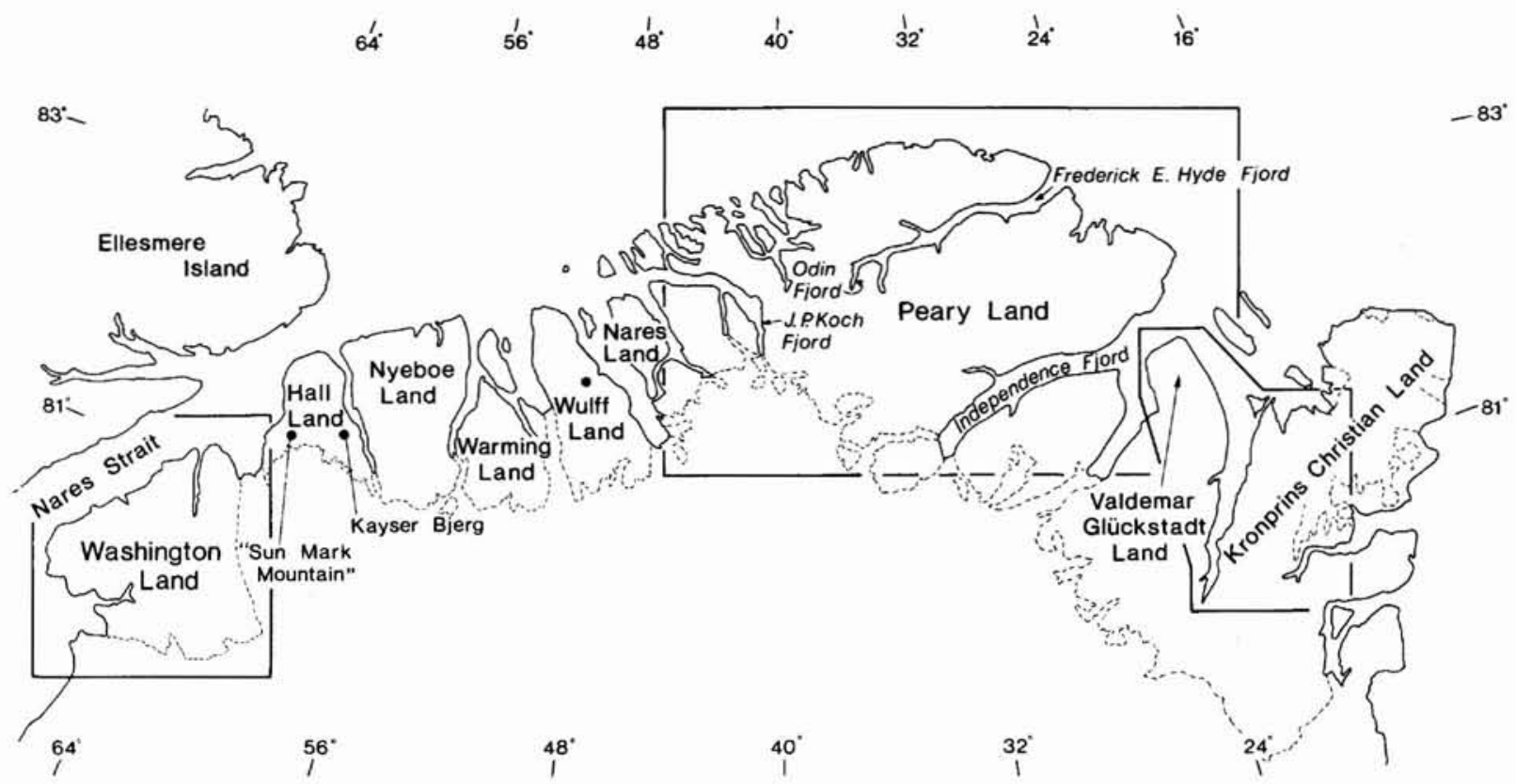

Fig. 2. General locality map. Detailed locality maps of Peary Land, Kronprins Christian Land and Washington Land are given in figs $3,4,14$.

sampling localities in more easterly areas (Peary Land, Kronprins Christian Land) and the extreme west of the region (Washington Land) reflects the distribution of field work carried out in North Greenland by the Geological Survey of Greenland (GGU) from 1974 to 1980. The intervening area (Hall Land - Freuchen Land) was visited only sporadically during this period, but Silurian strata were subsequently studied in detail by GGU during 1984 and 1985 (Larsen \& Escher, 1985, 1987; Sønderholm et al., 1987). The present monograph is based on samples collected during the first phase of GGU field work and does not include material collected in 1984 and 1985. Preliminary examination of this later material is summarised by Armstrong (1986a-c).

\section{Samples and techniques}

Samples intended for processing for conodonts were collected by a number of geologists (see acknowledgements), mainly in the course of compilation of sedimentary section logs. Generalised section logs are presented here, but full details are held by the Geological Survey of Greenland in Copenhagen.

Standard techniques of digestion in $10 \%$ acetic acid and separation of residues in bromoform were employed to recover conodonts from calcareous rock sam- ples. Indurated shale samples from the Wulff Land Formation (Thors Fjord Member) of Peary Land were crushed, dry sieved at $75 \mu \mathrm{m}$ and separated in bromoform. Scanning electron photomicrographs were taken on a Cambridge MK II stereoscan, using Ilford FP4 35 $\mathrm{mm}$ film. Specimens were coated with aluminium which was subsequently removed with a $5 \%$ solution of sodium hydroxide. 


\section{Lithostratigraphy and conodont biostratigraphy}

Formations are briefly described in ascending order within each geographical area. More detailed descriptions are given by Hurst $(1979,1980$ a,b, 1984; Hurst \& Surlyk, 1982), but see also Higgins et al. (in press), Larsen \& Escher (1985, 1987), Sønderholm et al. (1987), Smith et al. (1989).

\section{Peary Land - Kronprins Christian Land}

This area stretches from central Peary Land in the west to Kronprins Christian Land in the east (figs 2-4). Six formations and four members with a combined thickness approaching $800 \mathrm{~m}$ extend from the latest Ordovician (Richmondian) to the early Wenlock (Silurian).

\section{Turesø Formation}

The Tures $\varnothing$ Formation (figs 5-10) is between $115 \mathrm{~m}$ and $150 \mathrm{~m}$ thick in Peary Land increasing to some $200 \mathrm{~m}$ in Kronprins Christian Land (Hurst, 1984; Peel et al., 1981). It is characterised by medium to thick-bedded dolomite and limy dolomite with a distinctive alternation of light and dark grey beds. The beds are commonly strongly bioturbated as reflected by conspicuous mottling of the sediments. Rounded to irregular, calcite filled vugs are common; intraformational, flat-pebble conglomerates are found in the lower half of the formation (Armstrong \& Lane, 1981). The sediments of the Tures $\emptyset$ Formation suggest deposition in shallow subtidal to peritidal environments (Hurst, 1984).

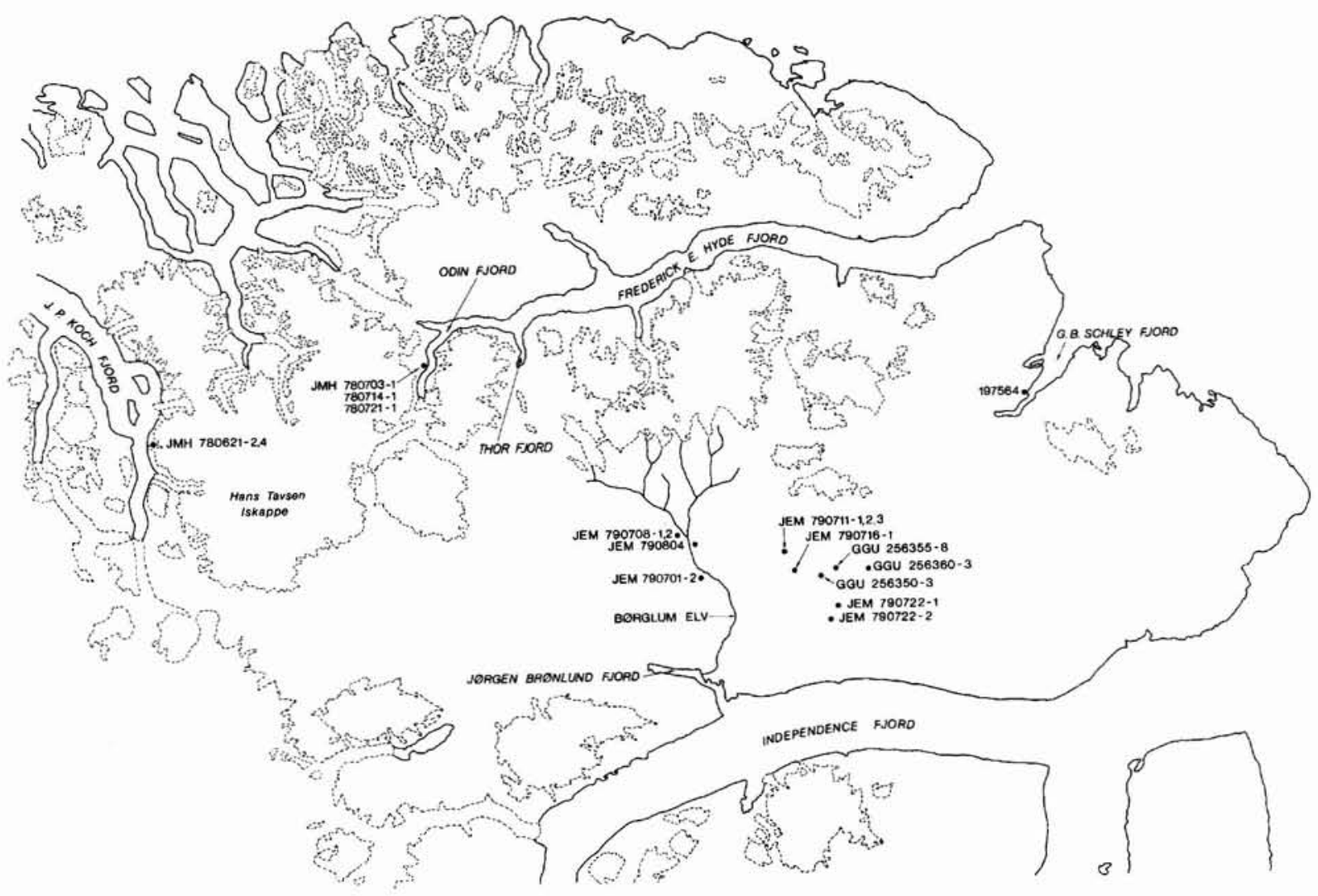

Fig. 3. Geological sections and spot sample localities in Peary Land. Sections are prefixed by the initials of the author (JEM, J. E. Mabillard; JMH, J. M. Hurst). Spot samples have GGU prefix. JMH 780703-1, see Hurst (1984, fig. 32); JMH 780714-1, see Hurst (1984, fig. 9); JMH 780721-1, see Hurst (1984, fig. 8). JEM 790701, see Hurst (1984, fig. 13); JEM 790708-1, see Hurst (1984, fig. 34, in part). 


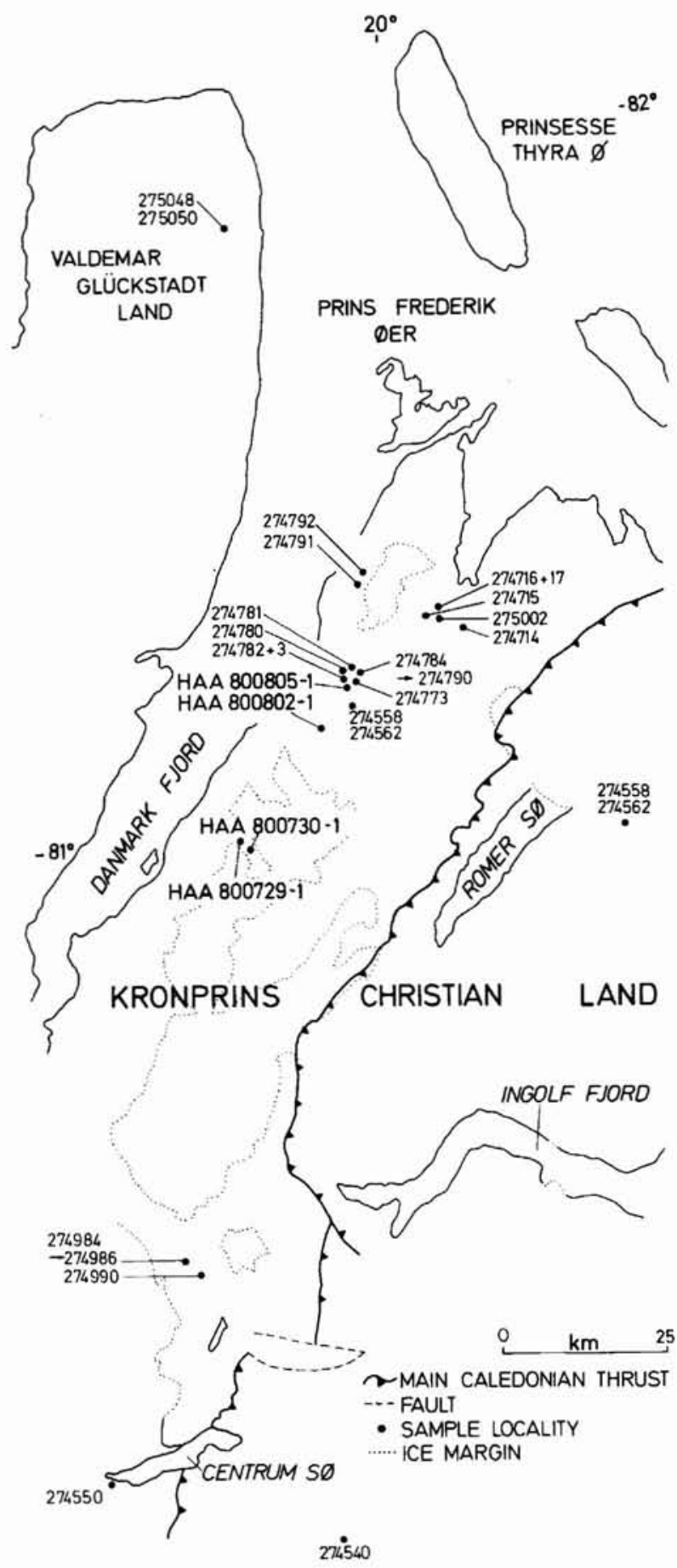

Fig. 4. Section and spot sample localities in Valdemar Glückstadt Land and Kronprins Christian Land. Spot samples are indicated by 6 -figure GGU numbers. Section localities with prefix of name of author (HAA, Howard A. Armstrong).
Cephalopods and Maclurites occur rarely in the lower part of the formation; the upper part contains coquinas dominated by virgianid brachiopods.

The lower $40-50 \mathrm{~m}$ of this formation in Peary Land contain a moderately diverse though sparse conodont fauna which includes Rhipidognathus symmetricus, Aphelognathus pyramidalis, Drepanoistodus suberectus, Plegagnathus dartoni, Oulodus sp. indet. 1 and Panderodus species. This fauna indicates a late Ordovician (Richmondian) age and can be referred to Fauna 12 of Sweet $e$ t al. (1971).

The succeeding $20-30 \mathrm{~m}$ of strata contain only rare Panderodus and are followed by Ozarkodina excavata and $O$. hassi; both the latter species are indicative of the early Silurian. The Ordovician-Silurian boundary cannot be accurately placed but lies at approximately $65 \mathrm{~m}$ above the base of the formation. Strata below this level lacking age-diagnostic species and could correlate with the Gamachian of Anticosti Island (McCracken \& Barnes, 1981). The remainder of the Tures $\varnothing$ Formation contains only sparse conodonts which typically have long ranges; they are considered, however, to be early to middle Llandovery.

\section{Ymers Gletscher Formation}

The Ymers Gletscher Formation (figs 5-7, 10) comprises $25-45 \mathrm{~m}$ of pale, thin to medium-bedded, welllaminated limestones, cryptalgalaminites and dark, laminated mudstones, suggesting that this formation was deposited in low-energy supratidal to shallow subtidal environments. Virgianid brachiopod coquinas and ostracode wackestones occur rarely and provide the only macrofossil data. Sparse conodonts including Aspelundia fluegeli from the type section at Odin Fjord and reference sections by Børglum Elv (figs $5,6,10$ ) indicate a middle to late Llandovery age.

\section{Odins Fjord Formation}

The Odins Fjord Formation (figs 5-10) is between 200 $\mathrm{m}$ and $350 \mathrm{~m}$ thick and appears to thicken from south to north in Peary Land. It is characterised by medium to thick-bedded dark weathering skeletal limestones.

Hurst (1984) interpreted the lower part of the formation to be indicative of low-energy shallow subtidal environments; temporary low-energy peritidal environments recur in central and eastern Peary Land (Melville Land Member). In the north, around Odin Fjord and Thor Fjord (fig. 2), low-energy, possibly subphotic environments predominate in the upper part of the formation. Occasionally anoxic bottom conditions occur (Bure Iskappe Member). Detailed sedimentological 




JEM 790804-1
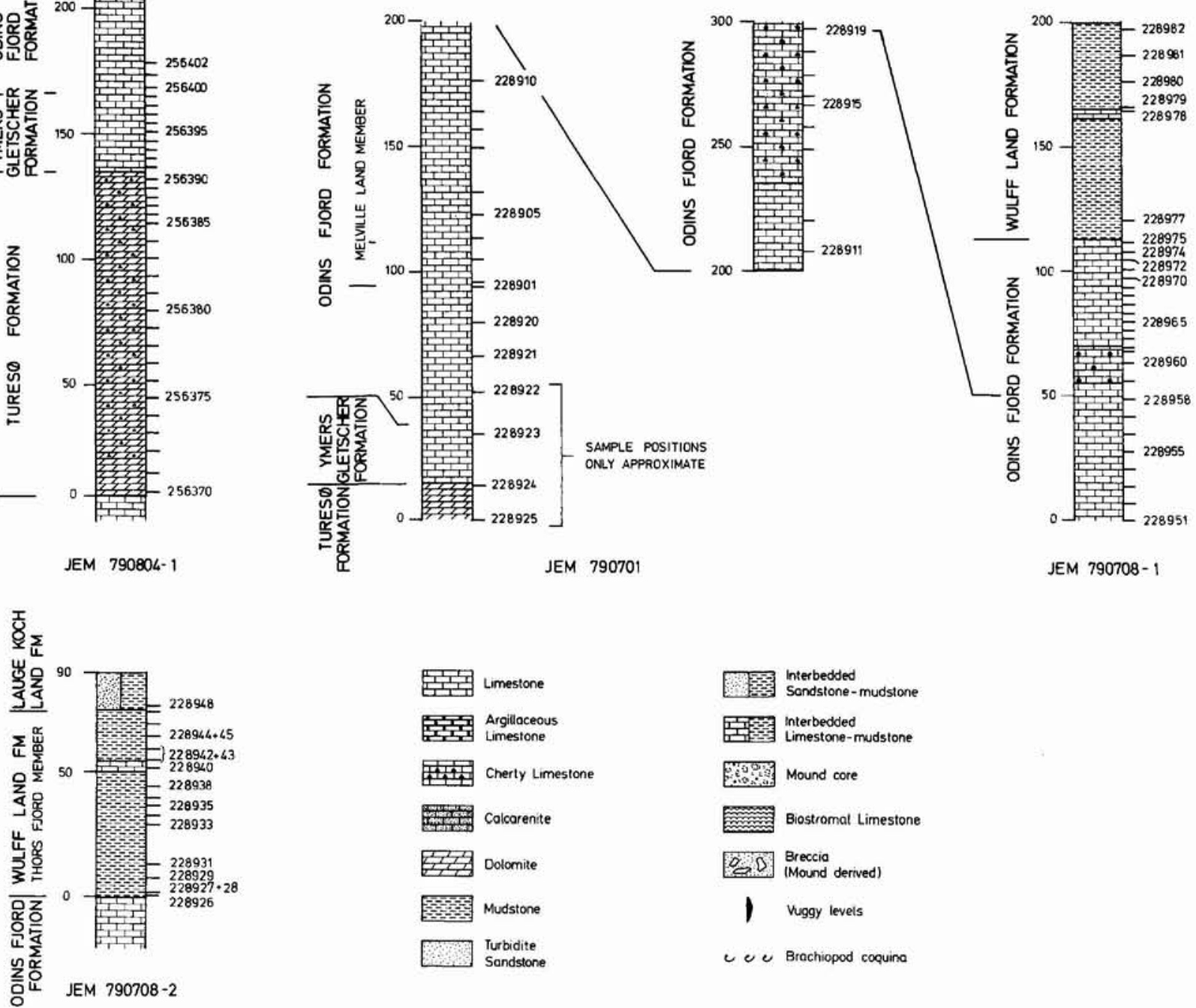

Fig. 5. Generalised section logs for localities in the valley of Børglum Elv, central Peary Land. For location of sections see fig. 3. Legend for all figures.

data are not available for Kronprins Christian Land; the available evidence suggests shallow subtidal depositional environments.

In the type section at Odin Fjord (Hurst 1984, fig. 9) Virgianella sp. and Kulumbella sp. occur $50-60 \mathrm{~m}$ above the base of the formation, suggesting a middle Llandovery age. Harpidium occurs $110 \mathrm{~m}$ above the base of the formation in a reference section to the north of the type section (Hurst, 1984, fig. 32) and is indicative of the late Aeronian and Telychian stages. Corals $110 \mathrm{~m}$ above the base of the formation at Børglum Elv suggest a similar age (Saied, 1979).

Conodonts are generally scarce in this formation, with taxa continuing from the Tures $\emptyset$ and Ymers
Gletscher Formations. Aspelundia fluegeli occurs $110 \mathrm{~m}$ above the base of the formation at Odin Fjord (fig. 10) and suggests a late Llandovery age. The upper part of the formation, however, contains abundant and diverse conodont faunas indicative of the Pterospathodus celloni Biozone. In the type section P. celloni occurs $2 \mathrm{~m}$ below the top of the formation; in sections to the south this species first appears progressively lower in the formation ( $5 \mathrm{~m}$ below the top at southern Odin Fjord, $15 \mathrm{~m}$ at Børglum Elv and $25 \mathrm{~m}$ in eastern Peary Land). $P$. celloni has also been recorded approximately $1 \mathrm{~m}$ below the top of the formation at G. B. Schley Fjord (sample GGU 197564, Table 3). This evidence may suggest that the top of the Odins Fjord Formation in Peary Land is 


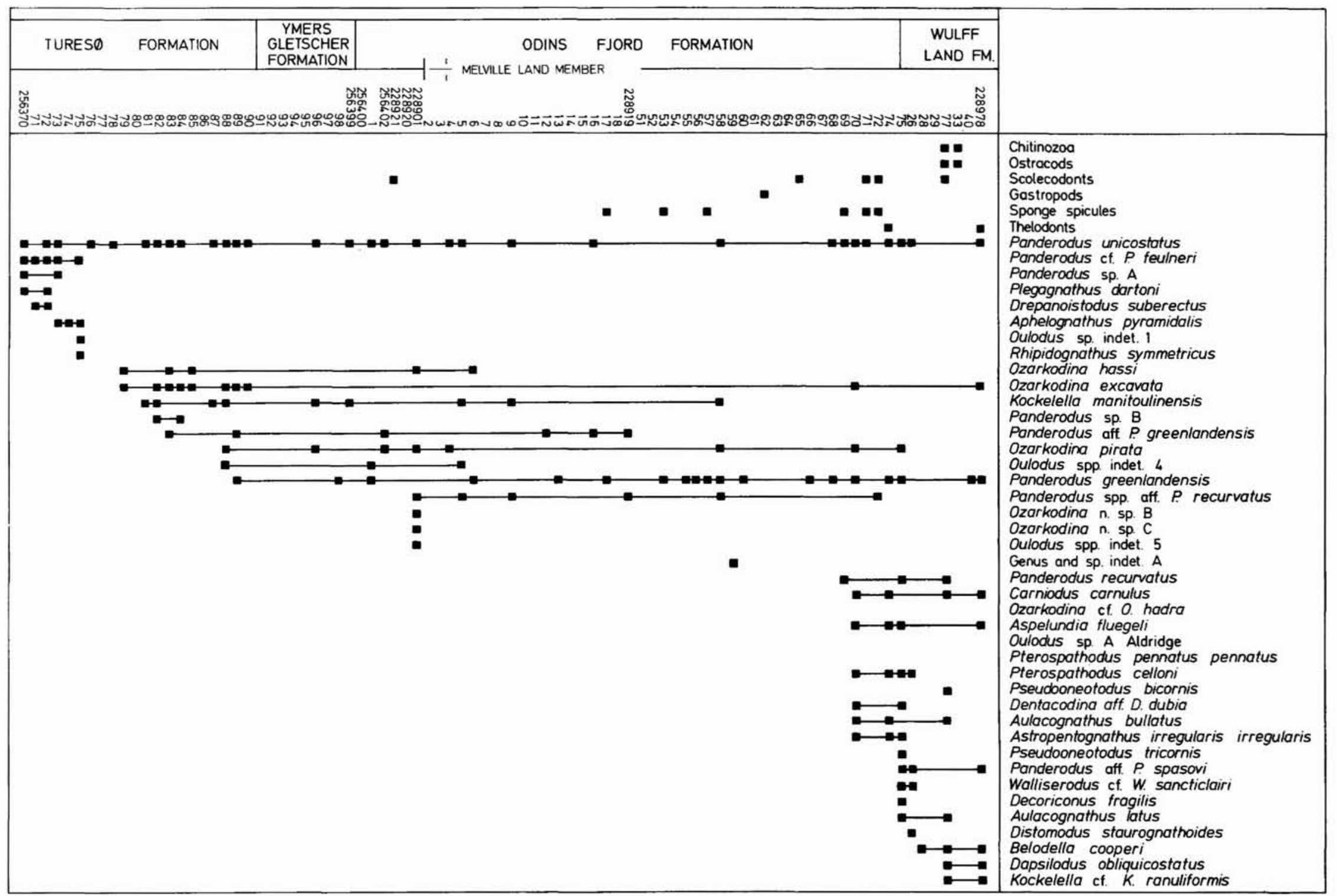

Fig. 6. Conodont range chart for central Peary Land. For location of samples see figs 3, 5 . 


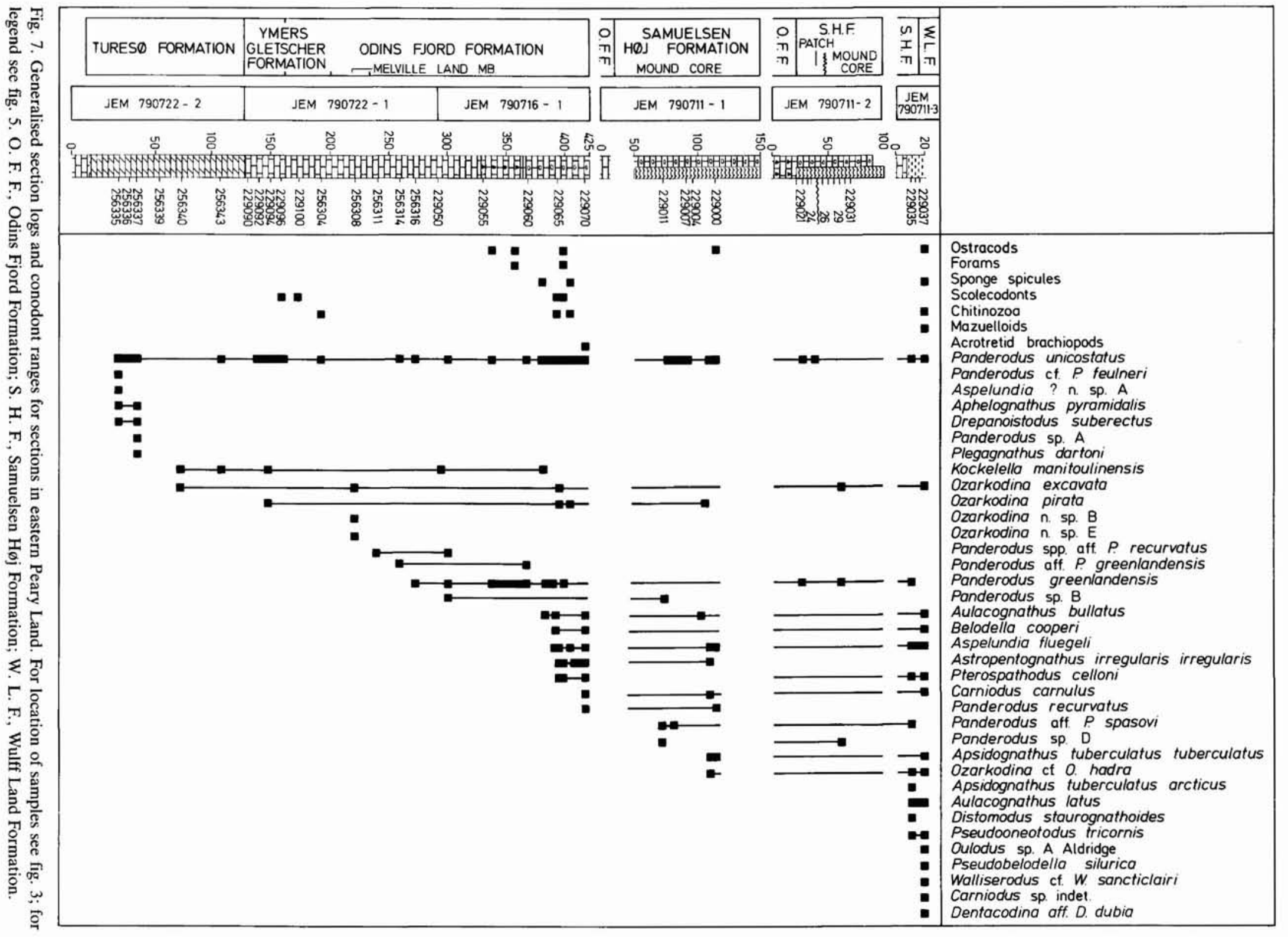


Fig. 8. Generalised section logs and location of conodont samples in Kronprins Christian Land. See fig. 4 for localities and fig. 5 for legend.

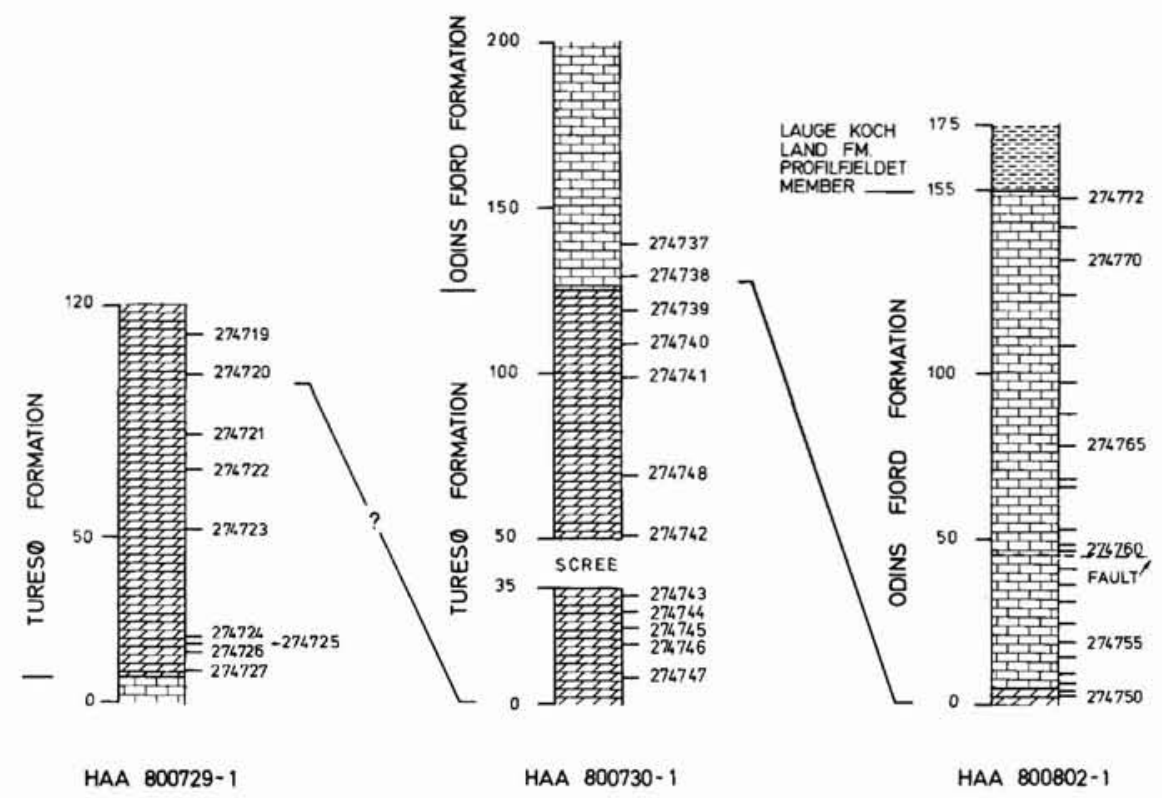

diachronous, younging south (refer also to Hurst, 1984, p. 46).

Other species typical of the Pterospathodus celloni Biozone include $P$. pennatus, Aulocognathus bullatus, Astropentagnathus irregularis irregularis, Apsidognathus tuberculatus, Aspelundia fluegeli, Distomodus staurognathoides, Belodella cooperi, Walliserodus curvatus and several species of Panderodus. A. bullatus occurs some $30 \mathrm{~m}$ below the top of the formation (in GGU sample 274769) in Kronprins Christian Land (fig. 9 ), but with no other $P$. celloni Biozone species. $P$. celloni first occurs $20 \mathrm{~m}$ below the top of the formation along with a moderately diverse fauna including $A$. bullatus, Ast. irregularis irregularis, Asp. fluegeli and Panderodus species. This first appearance correlates well with those at Børglum Elv and eastern Peary Land suggesting little diachroneity from Børglum Elv southeast to Kronprins Christian Land.

\section{Melville Land Member}

This member is between $15 \mathrm{~m}$ and $30 \mathrm{~m}$ thick thinning from cast to west and from south to north (Hurst, 1984). The Melville Land Member is absent at Odin Fjord and G. B. Schley Fjord and has not been described from Kronprins Christian Land or Valdemar Glückstadt Land. It contains rare ostracodes and brachiopods (Christie \& Peel, 1977) considered to be middle Aeronian in age. The conodont fauna from this member is extremely poor yielding rare Ozarkodina excavata, $O$. n. sp. B and $O$. n. sp. E from East Peary Land (figs 5, 6, 7).

\section{Bure Iskappe Member}

This member consists of characteristically thin to medium bedded skeletal limestones suggestive of deposition in low-energy, possibly anoxic, deep-shelf environments (Hurst, 1984).

Conodonts from Odin Fjord (fig. 10) and the brachiopod Harpidium sp. from the middle of the formation in its type section suggests middle to late Llandovery (Aeronian-Telychian).

\section{Samuelsen Høj Formation}

Hurst (1984) erected this formation to include the isolated carbonate mounds of Peary Land, Valdemar Glückstadt Land and Kronprins Christian Land. This formation does not occur west of central Peary Land. Isolated mounds vary in thickness from $50 \mathrm{~m}$ to $300 \mathrm{~m}$. Core facies consist of massive lime mudstone and flank deposits of thick-bedded skeletal limestones. In Kronprins Christian Land the carbonate mound complexes are embedded in thinly-bedded black lime mudstones. The mounds were deposited in high-energy environments well within the photic zone, while the surrounding mudstones possibly represent hemipelagic deposition after mound development had terminated (Hurst, 1984). 


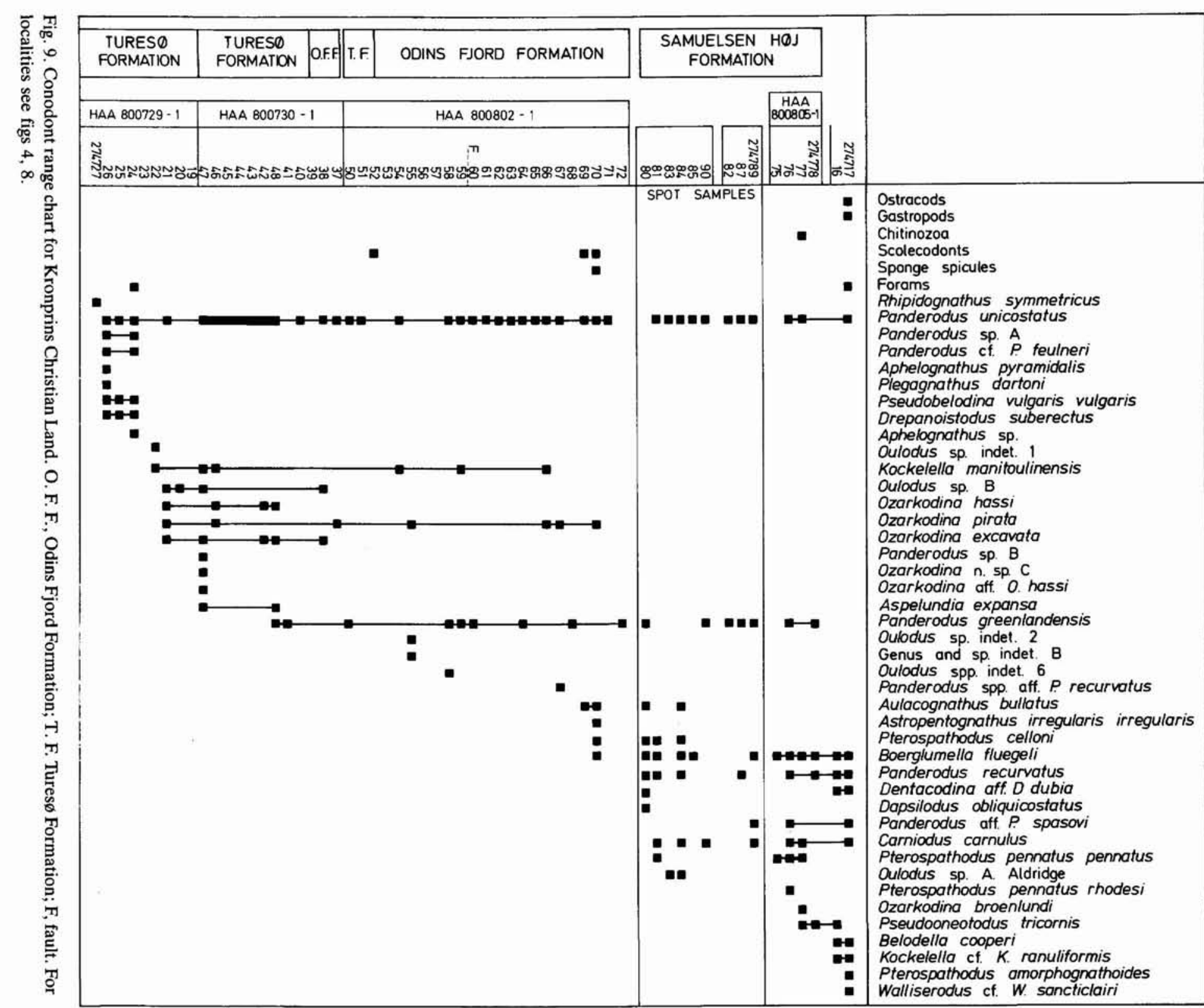


Fig. 10. Generalised section logs and conodont ranges near Odin Fjord, Peary Land (fig. 3). See fig. 5 for legend.

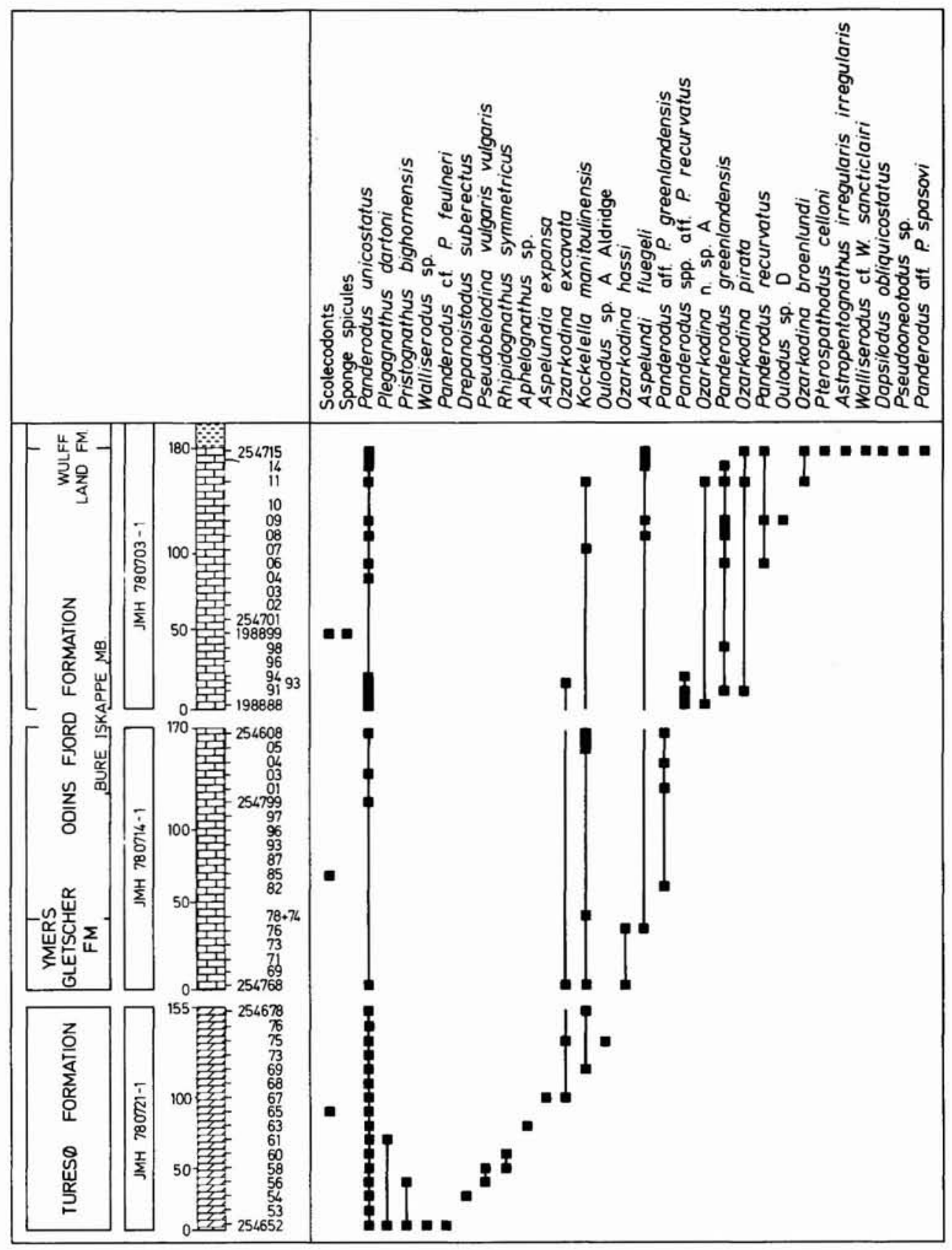

abundant and diverse late $P$. celloni Biozone to lower $P$. amorphognathoides Biozone fauna. It would appear that the Samuelsen $\mathrm{H} \varnothing \mathrm{j}$ Formation was deposited in an extremely short period of time within the P. celloni Biozone.

\section{Peary Land Group}

\section{Wulff Land Formation}

This formation (figs 5,6 ) is $12-300 \mathrm{~m}$ thick and dominated by black mudstone, with subordinate siltstone and sandstone, considered to have been deposited in a lower slope and basin-plain margin setting (Hurst \& Surlyk, 1982). 


\section{Thors Fjord Member}

The Thors Fjord Member (12-150 m) is characterised by mudstone with starved ripples, thin fine sandstone or siltstone and turbidites (Hurst \& Surlyk, 1982). Graptolites from the south of the outcrop suggest that this member ranges in age from the late Llandovery spiralis Biozone to the middle Wenlock flexilis or linnarssoni Biozones; in the north the member is contained within the late Llandovery spiralis Biozone (Hurst \& Surlyk, 1982). In Peary Land conodonts from thin argillaceous limestone beds within the lowest $5 \mathrm{~m}$ of this member contain Pterospathodus celloni, Apsidognathus tuberculatus arcticus, Aulocognathus latus, Distomodus staurognathoides, Pseudooneotodus tricornis, Pseudobelodella silurica, Walliserodus cf. W. sancticlairi and Dentacodina aff. D. dubia.

\section{Lauge Koch Land Formation}

The Lauge Koch Land Formation $(850-c .1500 \mathrm{~m})$ extends right across North Greenland from Kronprins Christian Land in the east to northern Hall Land in the west (Hurst \& Surlyk, 1980; Larsen \& Escher, 1985, 1987). In Kronprins Christian Land and north-eastern Valdemar Glückstadt Land, the formation rests on Silurian platform carbonates, farther to the east it overlies the Wulff Land Formation. The formation is dominated by sandstone and siltstone turbidites separated by mudstones.

\section{Profilfjeldet Member}

The Profilfjeldet Member is restricted to Kronprins Christian Land and Valdemar Glückstadt Land and includes discontinuous black mudstone and siltstone with the overlying sandstone turbidites (Hurst \& Surlyk, 1982).

In north-east Kronprins Christian Land graptolites date the base of this member as griestoniensis Biozone or very low spiralis Biozone (Telychian). In western Kronprins Christian Land graptolites of the spiralis Biozone occur and in Valdemar Glückstadt Land graptolites of the late Llandovery sakmaricus-laqueus Biozone occur close to the base of this member (Hurst \& Surlyk, 1982). Hurst \& Surlyk thus concluded that the base of the Profilfjeldet Member was diachronous, oldest in the east, younging slightly northwards and westwards. Graptolite data from Lane (1972) indicate that the base of this member in southern Kronprins Christian Land is middle Wenlock; thus the member also youngs to the south.

Two samples collected from thin limestones in the lower part of the Profilfjeldet member contained abundant and diverse conodont faunas. The lowest (GGU sample 274716) yields a Pterospathodus celloni Biozone fauna with, unusually, Belodella cooperi and Kockelella cf. $K$. ranuliformis. The upper sample (GGU 274717), collected $0.5 \mathrm{~m}$ higher, yields a $P$. amorphognathoides Biozone fauna with $P$. amorphognathoides and Walliserodus cf. W. sancticlairi (fig. 9). GGU sample 275048 from Valdemar Glückstadt Land (again from the lower part of the Profilfjeldet Member) contains $P$. pennatus rhodesi and $P$. amorphognathoides.

\section{J. P. Koch Fjord and Wulff Land}

Only scattered reconnaissance data were available from this general area of North Greenland, although subsequent field work during 1984-85 has permitted a full evaluation of the Upper Ordovician and Silurian sequences (Larsen \& Escher, 1985, 1987; Sønderholm $e t$ al., 1987; Smith et al., 1989; Higgins et al., in press).

\section{J. P. Koch Fjord}

A full section through strata of the Franklinian Basin is seen in the walls of the prominent fjord, J. P. Koch Fjord, which marks the western extremity of Peary Land (fig. 3). Hurst (1979), on whose collections of samples the following comments are based, formally divided uppermost Ordovician to Upper Silurian carbonates in the southern fjord area into three formations which have been correlated by Sønderholm et al. (1987) with the formal lithostratigraphic schemes employed in Washington Land and Peary Land. Lithological descriptions are given by Hurst (1979), see also Sønderholm et al. (1987).

The J. P. Koch Fjord region is a transition region in terms of stratigraphy of the Morris Bugt Group, and strata can be assigned either to the units recognised further east in Peary Land (Børglum River and Tures $\emptyset$ Formations) or to those recognised in more westerly regions (Kap Jackson and Aleqatsiaq Fjord Formations). Although the boundary between the latter two formations has lost its clarity at J. P. Koch Fjord on account of the easterly disappearance of the intervening Cape Calhoun Formation, they can be distinguished on outcrop near the section described by Hurst (1979; see present figs 3,11 ). Thus, in a recent map compilation, the western terminology of Kap Jackson and Aleqatsiaq Fjord Formations has been employed as far east as Hans Tavsen Iskappe (J. S. Peel, personal communication, 1988).

The Børglum River Formation of Peary Land east of Hans Tavsen Iskappe is thus equivalent to the Kap 


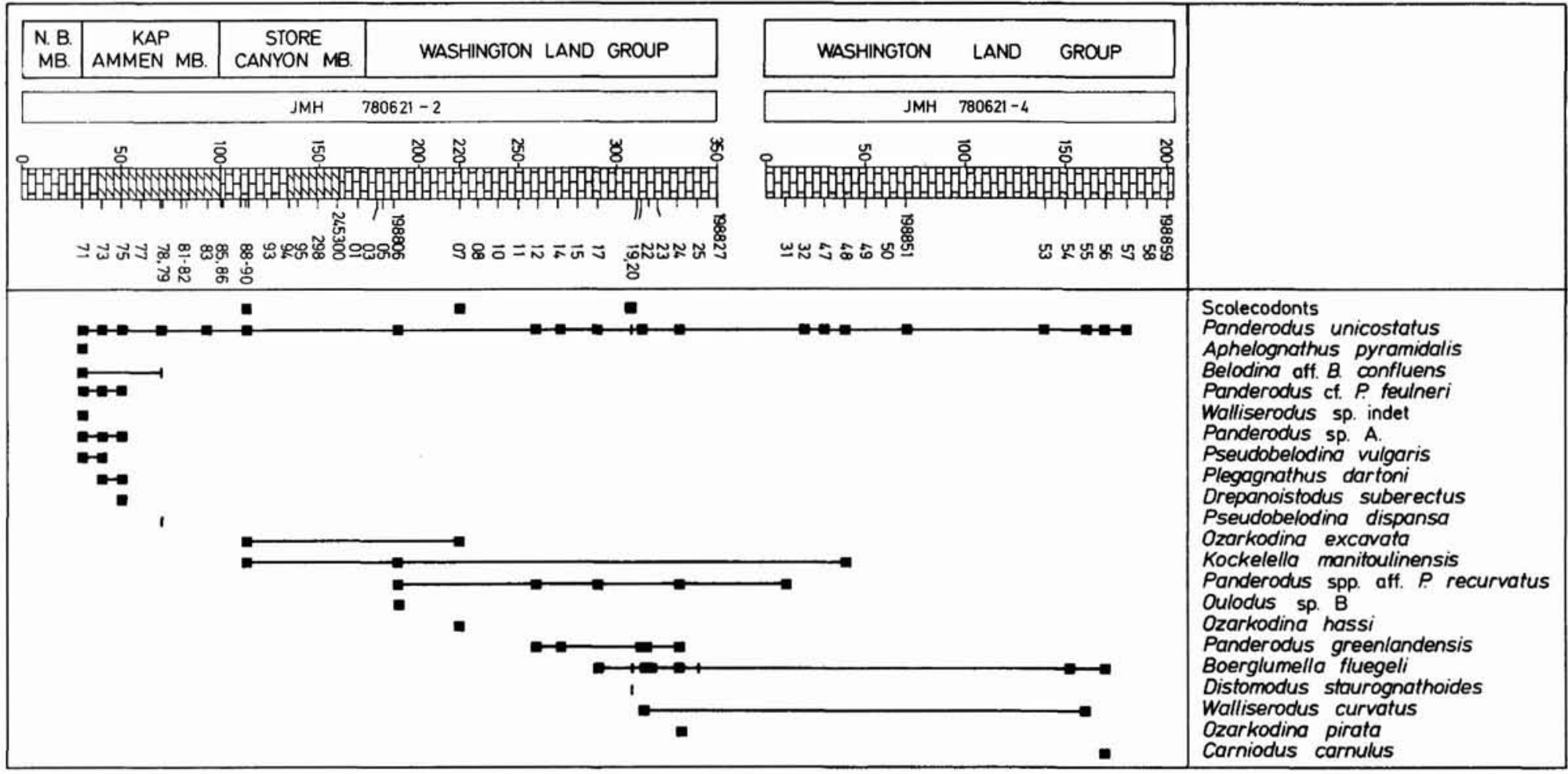


Jackson Formation and the overlying lower member of the Aleqatsiaq Fjord Formation (AF1 of Sønderholm $e t$ al., 1987; Newman Bugt Member of Smith et al., 1989).

In the following section, the original units of Hurst (1979) are re-interpreted in terms of this more recently available stratigraphic information.

\section{Aleqatsiaq Fjord Formation}

\section{Kap Ammen Member}

This corresponds to the Dolomite formation of Hurst (1979), and unit AF2 of Sønderholm et al. (1987). It consists of some $70 \mathrm{~m}$ of thin to medium-bedded dark grey, limy dolomite and conformably overlies the Newman Bugt Member (unit AF1) of the Aleqatsiaq Fjord Formation. The lower part contains a moderately diverse fauna including Rhipidognathus symmetricus, Aphelognathus pyramidalis, Belodina aff. B. confluens, Pseudobelodina vulgaris vulgaris, Plegagnathus dartoni, Drepanoistodus suberectus and Panderodus species (fig. 11). The presence of Pl. dartoni and Ps. vulgaris vulgaris indicates a middle to late Richmondian age (Sweet, 1979).

The upper $25 \mathrm{~m}$ yield only rare Panderodus unicostatus. Macrofossils include recrystallised tabulate corals (Favosites and Halysites), stromatoporoids and orthocone cephalopods.

\section{Store Canyon Member}

This variable sequence of fossiliferous limestones with subordinate limy dolomites is $80 \mathrm{~m}$ thick and was referred to the Dark limestone formation by Hurst (1979). The basal beds contain coquinas of virgianid brachiopods, along with tabulate corals, cephalopods and stromatoporoids. A bed approximately $5 \mathrm{~m}$ from the base of the formation contains Maclurites, indicating an Ordovician age (J. S. Peel, personal communication, 1987). Ozarkodina excavata and Kockelella manitoulinensis occur $10 \mathrm{~m}$ above the base and indicate a Silurian age. The juxtaposition of these faunas restricts the Ordovician-Silurian boundary to within $5 \mathrm{~m}$ of strata, at the top of the barren horizon (a horizon found throughout Peary Land). If Fauna 12 as developed in North Greenland is equivalent in age to the Fauna 12 of Sweet et al. (1971), then the barren horizon may be coeval with the Gamachian Stage, defined on Anticosti Island (McCracken \& Barnes, 1981).

The upper part of the formation is barren of cono- donts though stromatoporoids and large ostracodes occur.

\section{Washington Land Group}

Strata placed here equate with the 'White limestone formation' of Hurst (1979). Hurst (1979) recorded rare favositids and Harpidium sp., together with brachiopods, trilobites, ostracodes and corals from near the top of these $380 \mathrm{~m}$ of homogeneous light grey limestone. GGU sample 198807 close to the base contains Ozarkodina hassi suggesting an early to middle Llandovery age.

The upper $100 \mathrm{~m}$ contain relatively abundant conodonts including Aspelundia fluegeli, Distomodus staurognathides, Ozarkodina pirata, Panderodus greenlandensis, $P$. unicostatus, Walliserodus curvatus and Ozarkodina $\mathrm{n}$. sp. B., D. staurognathoides is not known from pre-mid Aeronian strata (fig. 24) Carniodus carnulus occurs $20 \mathrm{~m}$ from the top and indicates a probable Telychian age. From these data it appears that the 'White limestone formation' of the J. P. Koch Fjord area can be directly correlated with typical Washington Land Group as developed in Washington Land and the Odins Fjord Formation in Peary Land (see also Sønderholm et al., 1987). Transition to clastic deposition occurs within the Telychian.

\section{Wulff Land}

The lithostratigraphy of the area around 'Apollo $\$ \varnothing$ ' in eastern Wulff Land (fig. 2) was first described by Hurst \& Peel (1980). The basinal clastic sequence has subsequently been assigned to the Peary Land Group (Hurst \& Surlyk, 1982; Larsen \& Escher, 1985, 1987) while the upper part of the Silurian carbonate platform sequence is now known to be part of the Washington Land Group (Sønderholm et al., 1987). The latter, however, was only informally subdivided into mapping units east of Washington Land by Sønderholm et al. (1987) and hence the original informal stratigraphic scheme of Hurst \& Peel (1979) is used in this paper. Descriptions of the regional setting of the units can be found in Hurst (1980a), Sønderholm et al. (1987) and Higgins et al. (in press).

\section{Aleqatsiaq Fjord Formation}

The Aleqatsiaq Fjord Formation which straddles the Ordovician-Silurian boundary was defined in Washington Land (Peel \& Hurst, 1980) where it reaches a thickness of $360 \mathrm{~m}$ in the environs of Bessels Fjord (fig. 14). Subsequently the formation has been divided into three units (AF1-3) by Sønderholm et al. (1987) which were 


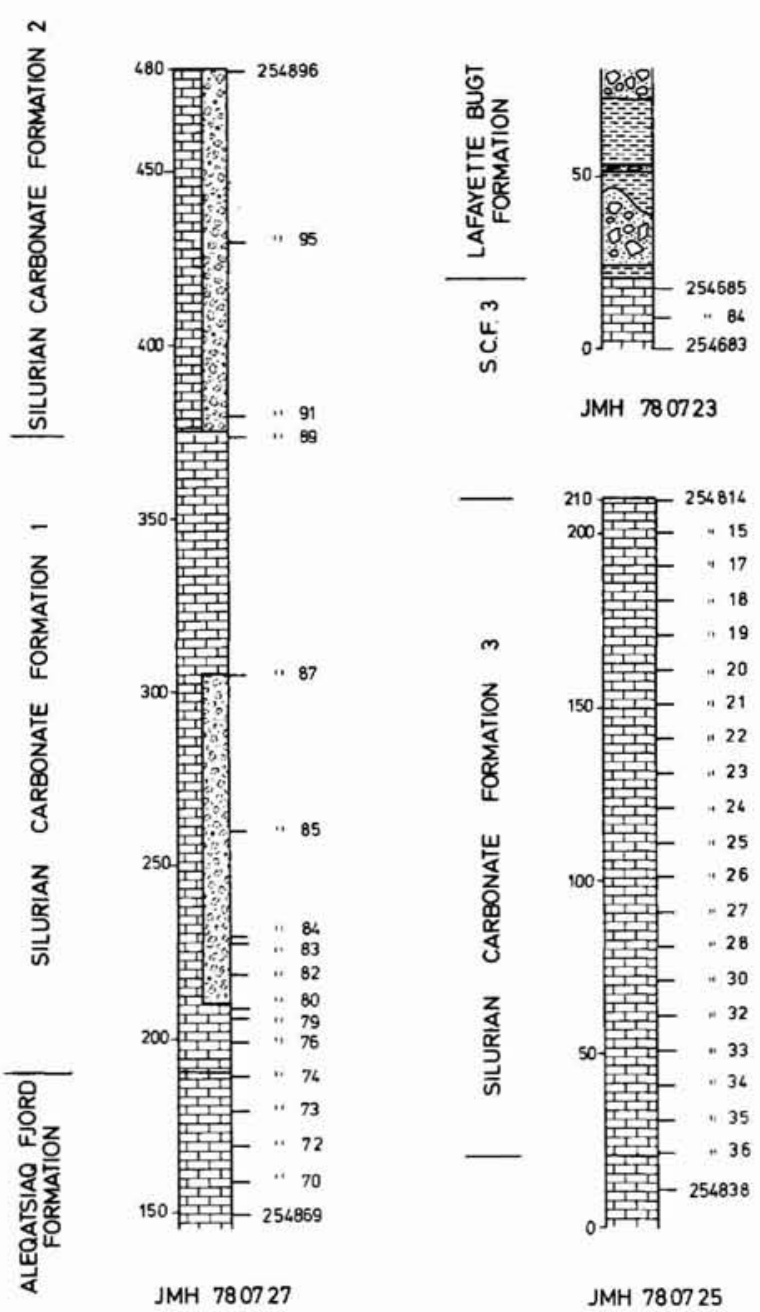

Fig. 12. Generalised section logs and conodont sample localities for sections north of Apollo Sø in Wulff Land (figs 1, 2). S. C. F. 3, Silurian carbonate formation 3. For legend see fig. 5.

given the names Newman Bugt, Kap Ammen and Store Canyon Members by Smith et al. (1989). These members can be followed across North Greenland and have also been recognised in Wulff Land where the formation has a measured thickness of $320 \mathrm{~m}$ at the northern end of 'Apollo S $\varnothing$ ' (M. Sønderholm, personal communication, 1987). This figure is at variance with the thickness of $130 \mathrm{~m}$ recorded some kilometres north of 'Apollo S $\emptyset$ ' by Hurst \& Peel (1979). Examination of their figure 10, however, where the Aleqatsiaq Fjord Formation is exposed on an $850 \mathrm{~m}$ high hillside, shows that the $130 \mathrm{~m}$ must be an underestimate and that the formation is approximately $250 \mathrm{~m}$ thick at this locality. This means that the stratigraphical position of samples within the formation (fig. 12) is somewhat obscured, and that results must be treated with care.
The formation consists of generally dark weathering, mottled, skeletal limestones which are patchily dolomitised. Hurst \& Peel (1979) recorded only a poor macrofauna from 'the upper part of the formation' consisting of tabulate corals, actinocerid cephalopods and Maclurites.

A single sample $30 \mathrm{~m}$ from the top of the formation contains Belodina aff. B. confluens, considered to be late Ordovician in age. A $10 \mathrm{~m}$ section with only Panderodus unicostatus follows; Ozarkodina n. sp. C and Walliserodus curvatus, $20 \mathrm{~m}$ from the top indicate an early Silurian age. Allowing for minor regional diachronism, the upper Aleqatsiaq Fjord Formation in Wulff Land correlates with that in Washington Land and Hall Land.

\section{Washington Land Group}

\section{'Silurian carbonate formation 1'}

This unit conformably overlies the Aleqatsiaq Fjord Formation and consists of a variable sequence of limestones and dolomites, approximately $185 \mathrm{~m}$ thick. It corresponds to the combined units WG1 and WG2 of Sønderholm et al. (1987); the oldest level of carbonate build-ups occurs within this formation (fig. 12).

The presence of Aspelundia expansa in GGU sample $254879,20 \mathrm{~m}$ above the base of the formation and directly beneath the carbonate build-up, suggests a preearly Aeronian age for the lower part of this formation which yields poor faunas, with the upper $140 \mathrm{~m}$ barren. Ozarkodina hassi occurs in GGU sample 254883, $42 \mathrm{~m}$ above the base, suggesting a pre-Telychian age for this part of the formation.

The conodont evidence suggests this mound complex was in part coeval with those found in the Adams Bjerg Formation, Pentamerus Bjerge Formation and Hauge Bjerge Formation (Kap Independence Member) of Washington Land.

\section{'Silurian carbonate formation 2'}

This unit consists of a variable sequence of limestone up to $180 \mathrm{~m}$ thick, containing a carbonate build-up complex (Hurst \& Peel, 1979); it is referred to unit WG3 of Sønderholm et al. (1987). The carbonate mound originates close to the base of the formation and reaches $100 \mathrm{~m}$ in thickness in its core facies. Along strike and towards the south the mound complex grades into a monotonous sequence of thin-bedded, dark weathering, black, nodular lime mudstones. The formation only contains a poor macrofauna of disarticulated 


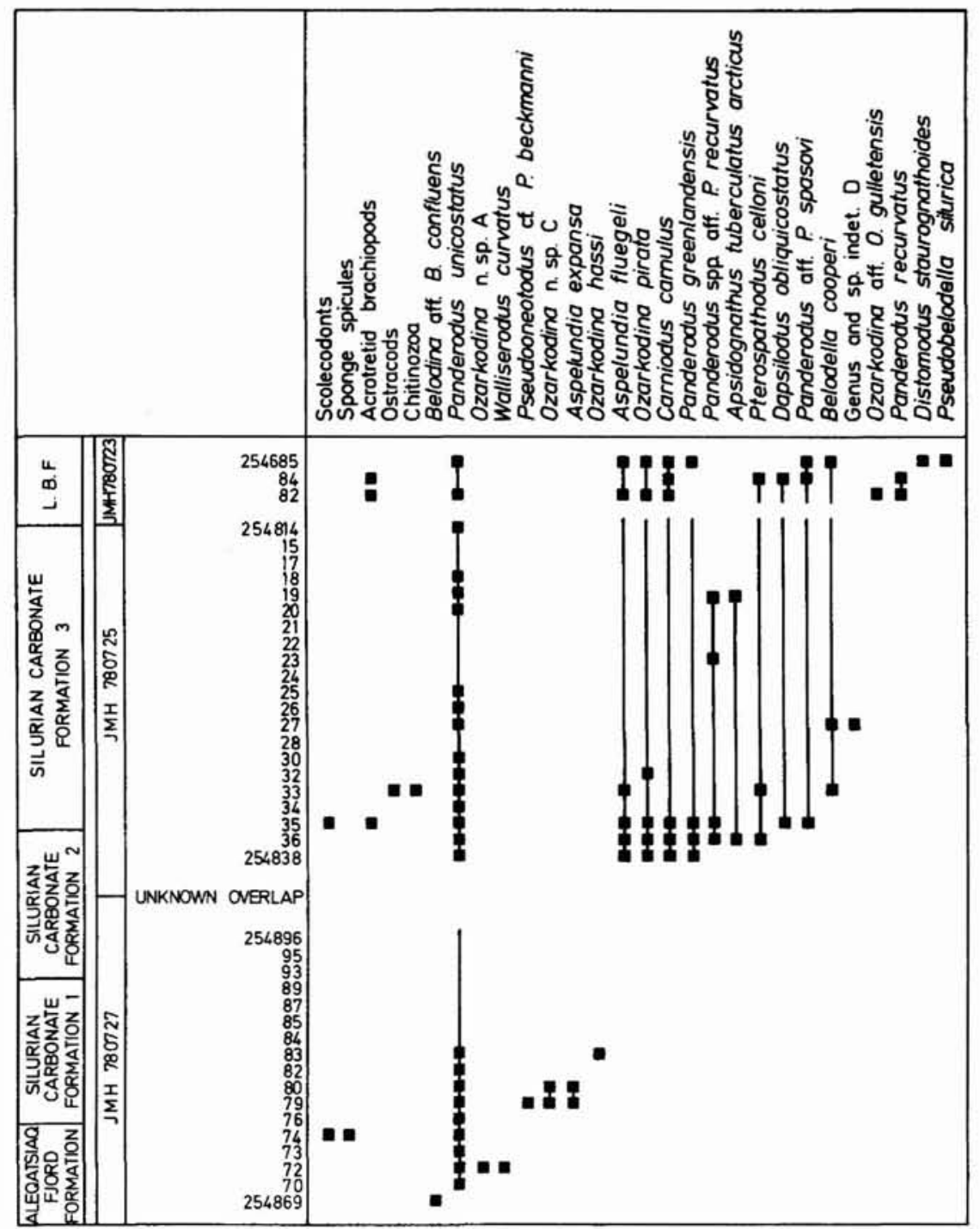

Fig. 13. Conodont range chart for sections north of Apollo Sø in Wulff Land (see figs 1, 2,12 and fig. 5 for legend). L. B. F., Lafayette Bugt Formation; this is the shale and breccia formation of Hurst \& Peel $(1979$, figs 9, 10), termed the Lafayette Bugt Formation by Hurst \& Surlyk (1982).

pentamerids (Harpidium sp. ?) stromatoporoids and tabulate corals, suggesting a middle Aeronian age.

The unit is barren of conodonts until the top, where GGU sample 254836 contains a possible Pterospathodus celloni Biozone consisting of Carniodus carnulus, Aspelundia fluegeli, Ozarkodina pirata and Panderodus greenlandensis (fig. 13). P. celloni does not occur until $5.5 \mathrm{~m}$ above this sample, suggesting that the base of the P. celloni Biozone in Wulff Land occurs at or close to the boundary between Silurian carbonate formations 2 and 3 .

\section{'Silurian carbonate formation 3'}

Silurian carbonate formation 3 of Hurst \& Peel
(1979), equivalent to unit WG4 of Sønderholm et al. (1987), consists of a monotonous sequence of massively bedded skeletal limestones and mudstones some $200 \mathrm{~m}$ thick. The base of the formation is marked by a thick intraformational conglomerate. The formation contains a rich macrofauna of trilobites, corals, stromatoporoids, brachiopods and crinoid debris, suggested by Hurst \& Peel (1979) to be of Aeronian or Telychian aspect.

Conodonts are moderately abundant and the whole formation yields a standard Pterospathodus celloni Biozone fauna (fig. 13). Conodonts are particularly abundant and diverse at the top of the formation in section JMH 780723 (figs 12, 13). The presence of Pseudobelodella silurica in GGU sample 254685 , suggests a late Pterospathodus celloni Biozone age (latest Telychian). 


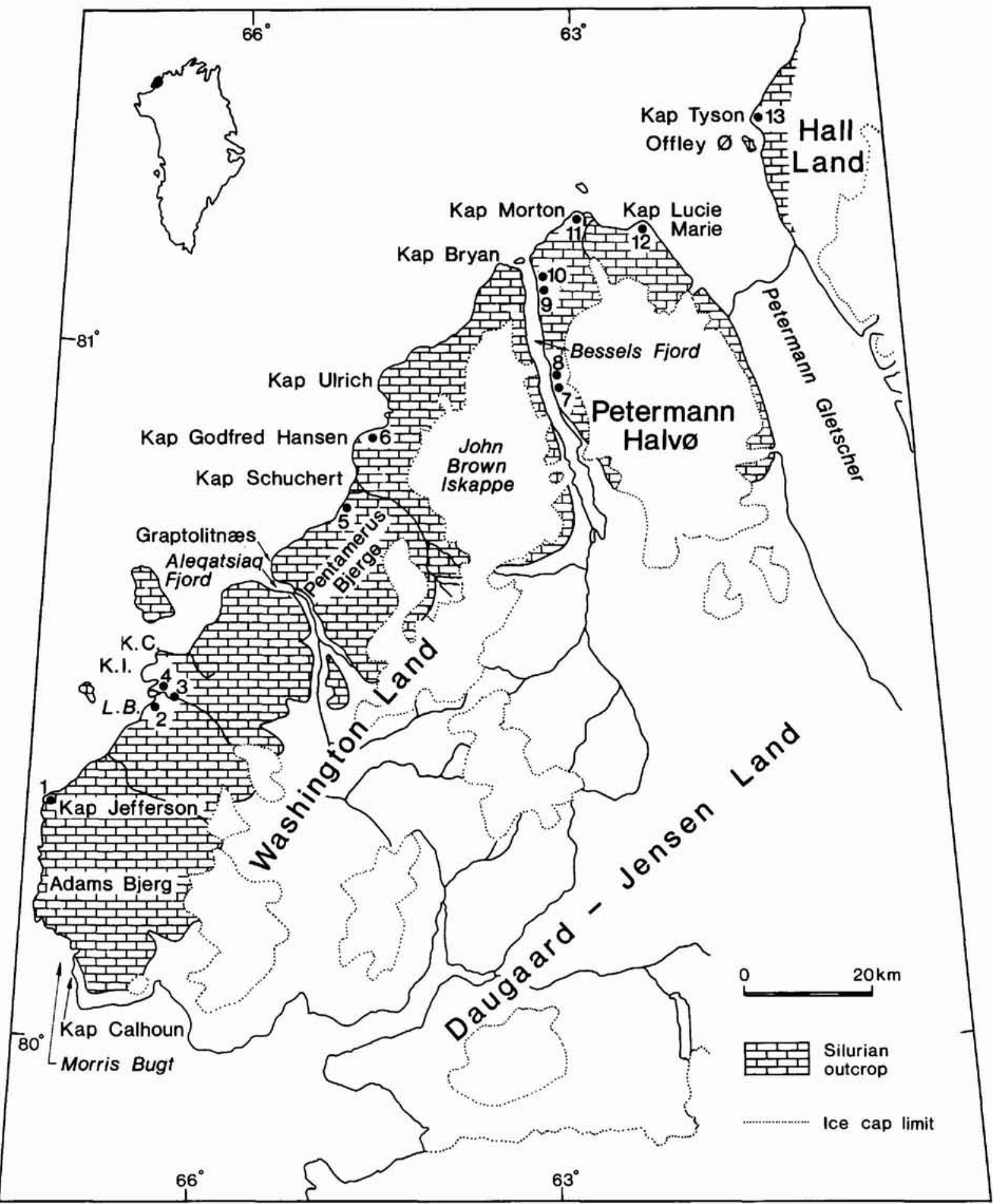

Fig. 14. Conodont localities in Washington Land and western Hall Land. Locality numbers refer to sections in figs 16-20. K. I., Kap Independence; K. C., Kap Constitution; L. B., Lafayette Bugt. 


\section{Washington Land and western Hall Land}

Silurian sediments in Washington Land and western Hall Land (fig. 14) were deposited in two major environments (Hurst, 1980b). Platform carbonates are referred to the Morris Bugt Group (Peel \& Hurst, 1980; Smith et al., 1989) and the Washington Land Group (Hurst, 1980b), while slope deposits are refered to the Peary Land Group (Hurst, 1980b). Facies changes within and between these environments are complex and abrupt (fig. 15).

All formations, except the Pentamerus Bjerge and Kap Lucie Marie Formations, have yielded conodonts. Generally conodonts from this region are better preserved (Conodont Alteration Index 1-2) than those from Peary Land, but the majority of samples are small and species diversity is low in both environments. The stratigraphical distribution of conodont species in this region is summarised in fig. 16 .

\section{Morris Bugt Group}

\section{Aleqatsiaq Fjord Formation}

This is the youngest formation in the predominantly Ordovician Morris Bugt Group. Hurst (1980b) considered these strata to represent deposition on an open marine, shallow shelf. Lithologically the formation consists of dolomitised massive lime mudstones and wack- estones. Hurst (1980b) reported Ordovician conodont species identified by R. J. Aldridge to within $40 \mathrm{~m}$ of the top of this formation at Aleqatsiaq Fjord and at Kap Independence.

At Kap Jefferson (figs 14, 17) GGU samples 216719-29 within the upper Aleqatsiaq Fjord Formation (conformably beneath the Adams Bjerg Formation) contain Aspelundia fluegeli, Dapsilodus obliquicostatus, Oulodus spp., Walliserodus bicostatus and Panderodus spp., a fauna indicating an middle Aeronian age. Elsewhere the top of the Aleqatsiaq Fjord Formation lies close to the Rhuddanian-Aeronian boundary (fig. 23), suggesting either misidentification of this formation at Kap Jefferson or unusual local circumstances which allowed the continuation of Aleqatsiaq Fjord Formation 'facies' into the Aeronian.

\section{Washington Land Group}

\section{Adams Bjerg Formation}

The Adams Bjerg Formation (130-200 m, fig. 17) consists predominantly of white, creamy dolomite with stromatolitic laminae. At Kap Jefferson a mound-like build-up is developed, from the top of which Hurst (1980b) reported a single specimen of Virgiana sp., considered a pre-middle Aeronian form. The formation contains only undiagnostic Panderodus unicostatus. As pelundia fluegeli in the underlying Aleqatsiaq Fjord Formation suggests a post middle Aeronian age.

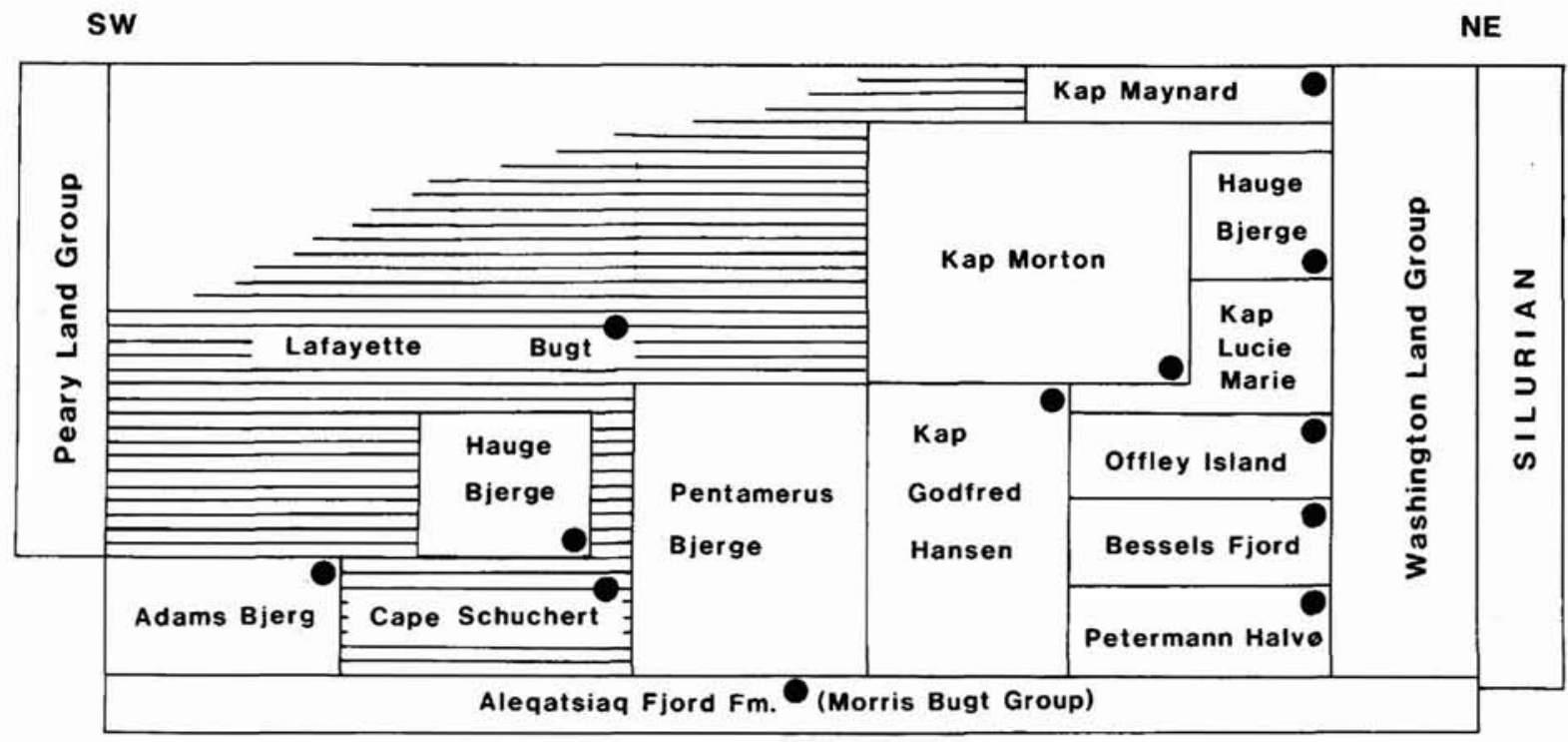

Fig. 15. Silurian stratigraphy in Washington Land and western Hall Land. Formations yielding conodonts are indicated by filled circles (from Peel, 1982, after Hurst, 1980b). 


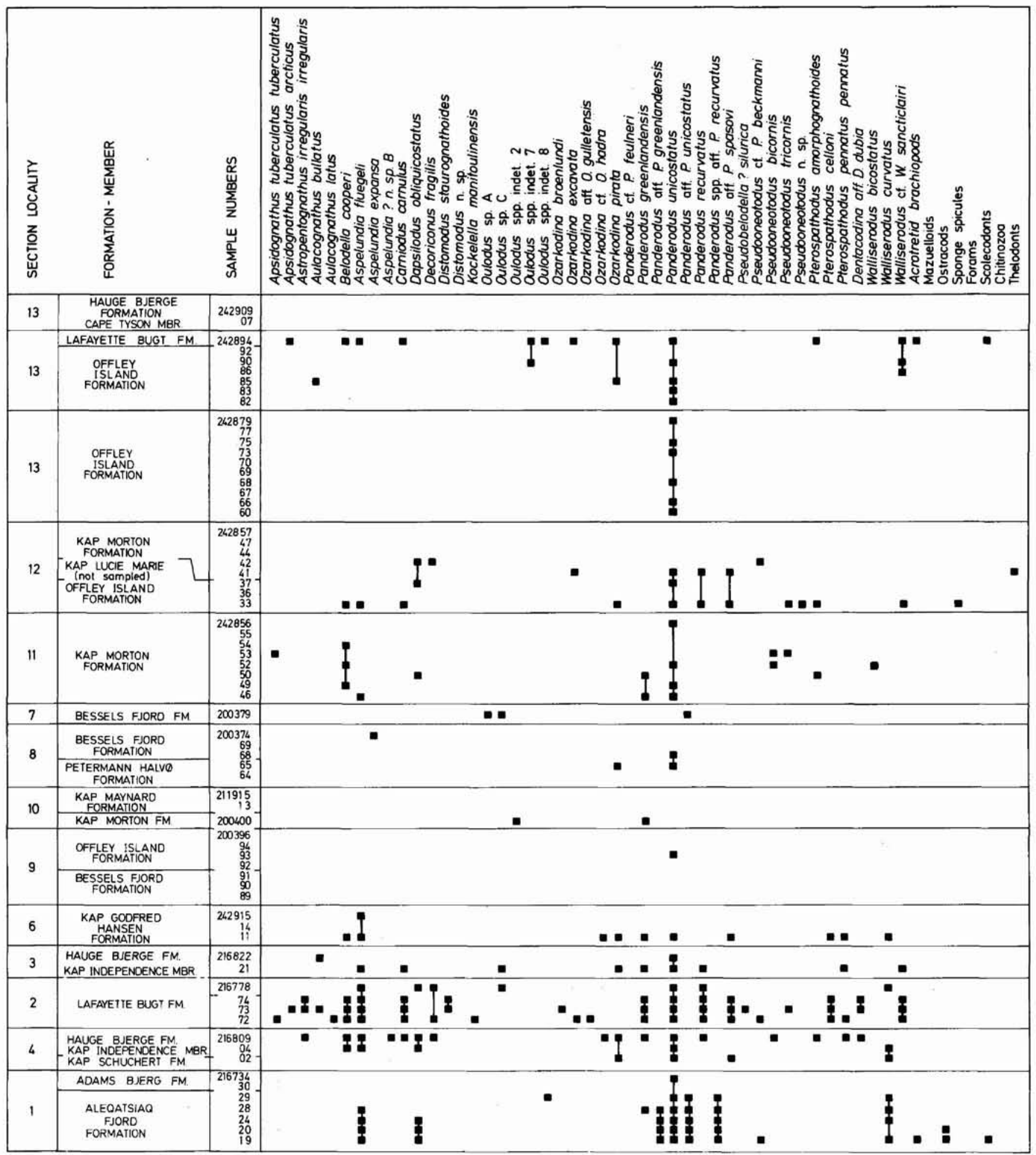

Fig. 16. Stratigraphical distribution of conodonts in Washington Land and western Hall Land. For localities and geological sections see figs 14, 17-20. GGU 216778 is from the Lafayette Bugt Formation at Kap Independence (fig. 14), see Hurst (1980b, fig. 61 , section height $107 \mathrm{~m}$. 

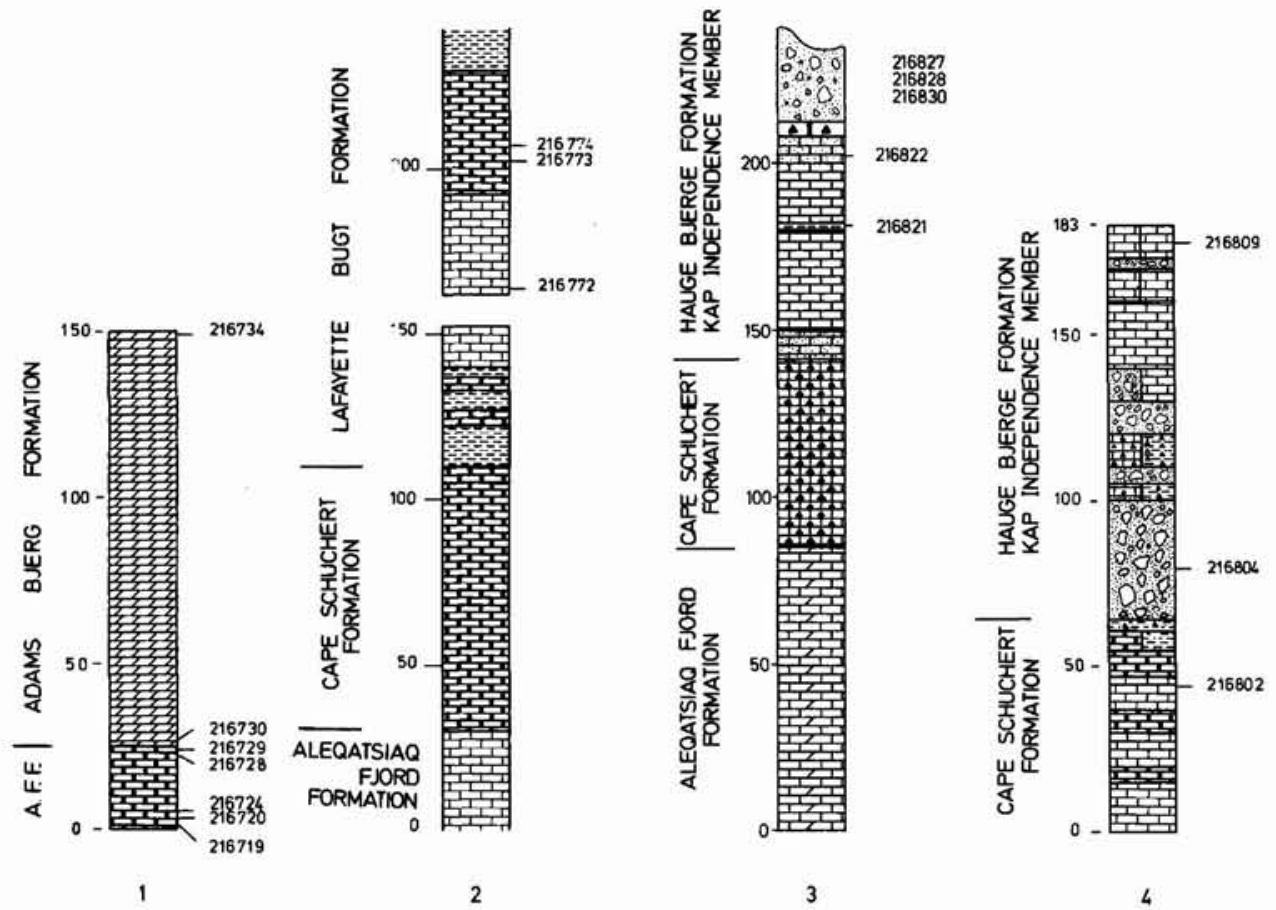

Fig. 17. Generalised section logs for localities $1-4$ (fig. 14) in Washington Land. For legend see fig. 5. Derivation of logs: 1, Hurst (1980, fig. 16); 2, Hurst (1980b, fig. 58, in part); 3, J. M. Hurst (unpublished); 4, Hurst (1980b, fig. 56). GGU samples 216827, 216828 and 216830 were collected from loose blocks of Kap Independence Member lithologies.

\section{Petermann Halvø Formation}

In the type section the lower $20 \mathrm{~m}$ of the formation are composed of cream-yellow dolomite, the remaining $75 \mathrm{~m}$ are light grey massive dolomite with rare, calcareous pebble breccias and laminated crinoidal calcarenites (fig. 18). Hurst (1980b) interpreted these rocks as having been deposited on the shelf in marginal to open marine areas.

Diagnostic macrofossils have not been recorded from this formation and only few conodonts occur. If the top of the Aleqatsiaq Fjord Formation is synchronous, then the base of the Petermann Halvø Formation is late Rhuddanian to early Aeronian. Ozarkodina pirata and Distomodus sp. indet. are not age diagnostic forms but the former is found along with Kockelella manitoulinensis and $O$. excavata in the pre-Telychian strata of Peary Land.

\section{Pentamerus Bjerge Formation}

This formation represents a fringing reef complex located at the platform-slope boundary (Hurst 1980b; Hurst \& Surlyk, 1983b). Conodonts provide indirect evidence for a maximum age of this formation in that blocks occurring in breccia beds within the Lafayette Bugt Formation (fig. 21) derived from the Pentamerus Bjerge Formation contain a late Pterospathodus celloni or $P$. amorphognathoides Biozone fauna representing a Llandovery-Wenlock boundary age. This formation lies conformably above the Aleqatsiaq Fjord Formation and would therefore appear to range from the middle Llandovery into the Wenlock.

\section{Kap Godfred Hansen Formation}

The Kap Godfred Hansen Formation (250-300 m) consists of thick units of resedimented carbonate conglomerates derived from the Pentamerus Bjerge Formation and is interpreted to form part of a large submarine fan complex (Hurst 1980b; Hurst \& Surlyk, 1983a). The formation conformably follows the Aleqatsiaq Fjord Formation in the type section. In the reference section (fig. 18, loc. 6) GGU sample 242911 yielded Pterospathodus celloni, $P$. pennatus pennatus, Walliserodus $\mathrm{cf} . W$. sancticlairi, Pseudobelodella silurica, Dentacodina aff. D. dubia and Ozarkodina species (fig. 16). These suggest a late Telychian age. (fig. 16). From 50 to $130 \mathrm{~m}$ above this level, where the Lafayette Bugt and Kap Godfred Hansen Formations interdigitate, Hurst 
Fig. 18. Generalised section logs for localities 6-8 (fig. 14) in Washington Land. For legend see fig. 5. Derivation of logs: 6, Hurst (1980b, fig. 26 , in part); 7 , Hurst (1980b, fig. $36 \mathrm{D}$ in part); 8 , Hurst (1980b, fig. 36C).

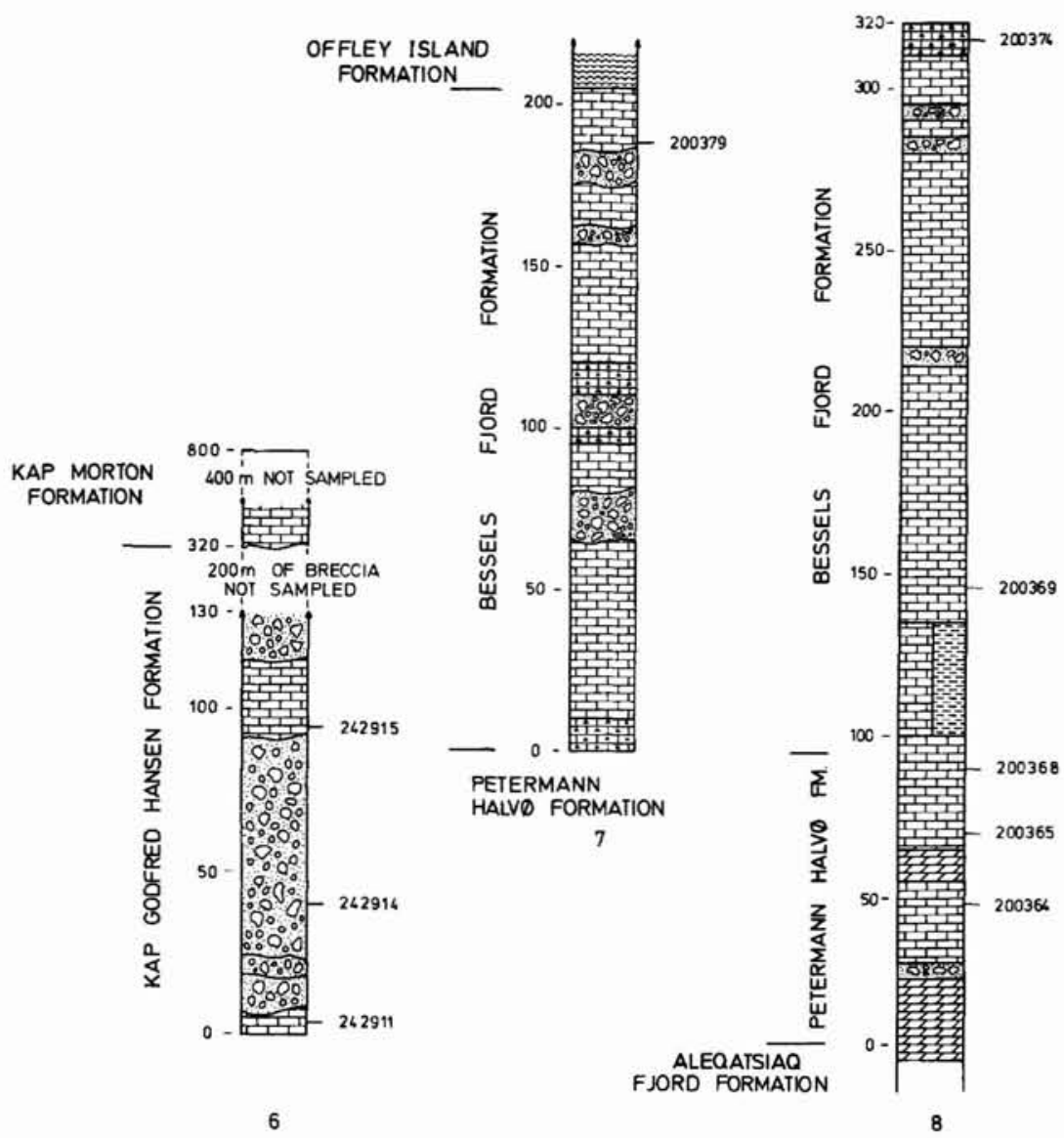

(1980b) reported graptolites of latest Llandovery to early Wenlock age. At the top of the formation in the type section coquinas of Kirkidium (Khodalovechia) sp. occur, a genus not known elsewhere in strata older than middle Wenlock. The overlying Kap Morton Formation has elsewhere yielded conodonts of Wenlock age (see below); hence the Kap Godfred Hansen Formation ranges in age from early middle Llandovery to middle Wenlock.

\section{Bessels Fjord Formation}

The Bessels Fjord Formation (550-600 m, figs 18-20) is a complex unit of dark inter-mound sediments containing isolated carbonate build-ups. The build-ups consist of massive lime mudstones; intermound sediments are lithologically complex, comprising black, laminated, dolomitic limestone, chert, shale, dark lime mudstone and poorly laminated mudstone.

The formation has not yielded diagnostic conodont faunas, but lithostratigraphic evidence and the presence of Harpidium sp. suggest a middle-late Llandovery age (Hurst, 1980b).

\section{Offley Island Formation}

The Offley Island Formation is a dominantly biostromal unit up to $450 \mathrm{~m}$ thick showing rapid lateral facies variations (figs 19,20) representing an open, shallow marine shelf (Hurst, 1980b). The formation is conformably overlain by the Kap Lucie Marie Formation in Washington Land and by the Hauge Bjerge Formation (Cape Tyson Member) or Lafayette Bugt Formation in Hall Land.

Abundant macrofossil data are available from this formation indicating a late Llandovery age (Hurst, $1980 \mathrm{~b})$. Some $10 \mathrm{~m}$ above its base at Kap Lucie Marie (figs 14, 19), the formation contains a Pterospathodus celloni Biozone fauna (section 12, fig. 16). GGU sample 242894 (section 13, fig. 16), in the Lafayette Bugt Formation at Kap Tyson (fig. 20), contains P. amorphognathoides. Microfossil data thus suggest that the whole of this formation is of late Llandovery age. 

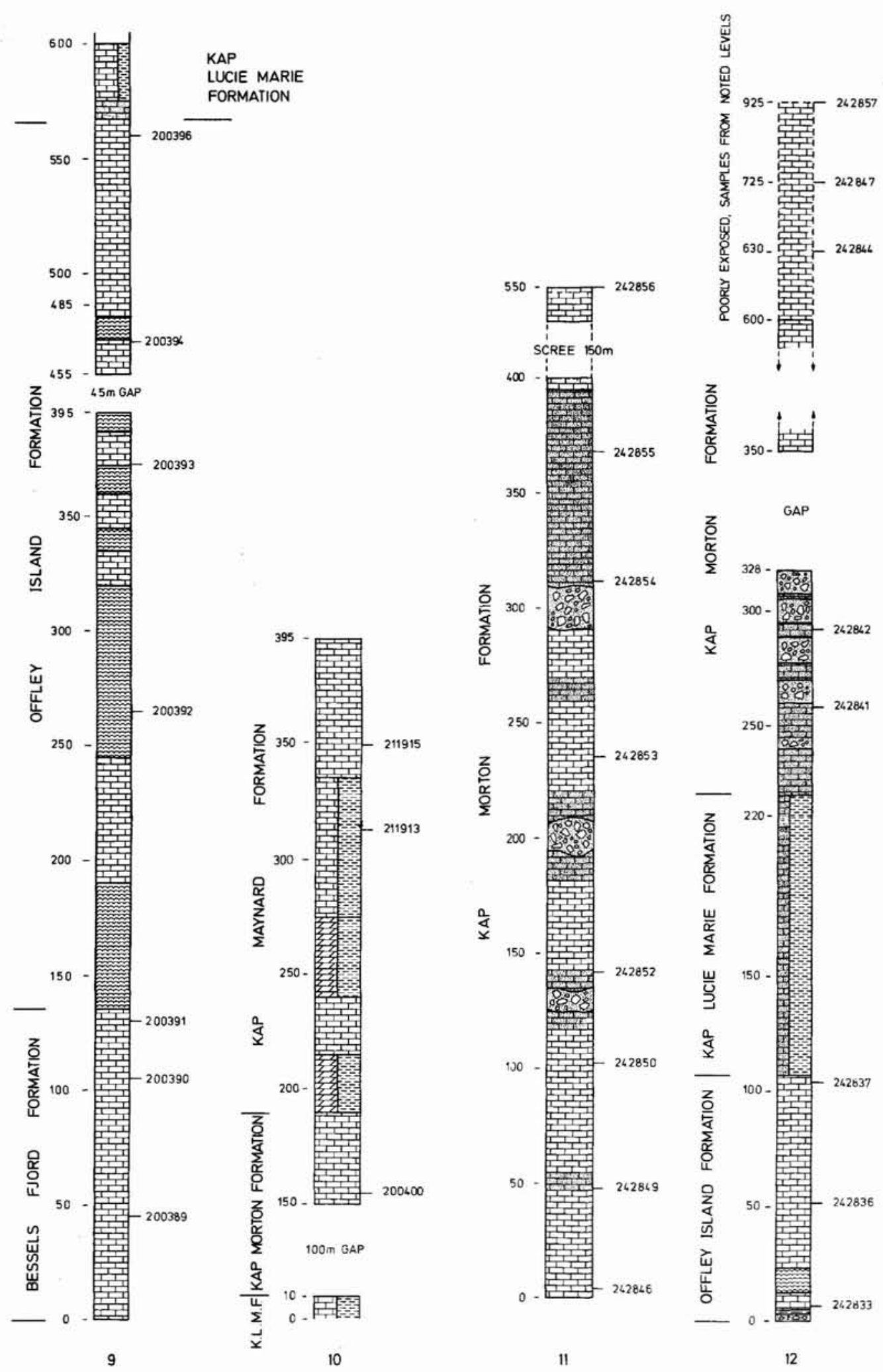

Fig. 19. Generalised section logs for localities 9-12 (fig. 14) in Washington Land. For legend see fig. 5. Derivation of logs: 9, Hurst (1980b, fig. 36A $\mathrm{A}_{1}$ ); 10, Hurst (1980b, fig. 36B $\mathrm{B}_{1}$ ); 11, Hurst (1980b, fig. 49); 12, Hurst (1980b, fig. 46). 
Fig. 20. Generalised section logs for locality 13 (fig. 14) in Hall Land. For legend see fig.

5. See also Hurst (1980b, fig. 43).

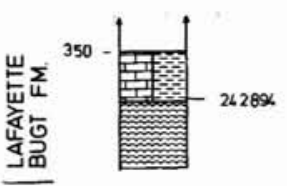

$70 \mathrm{~m}$ NOT ACCESSIBLE
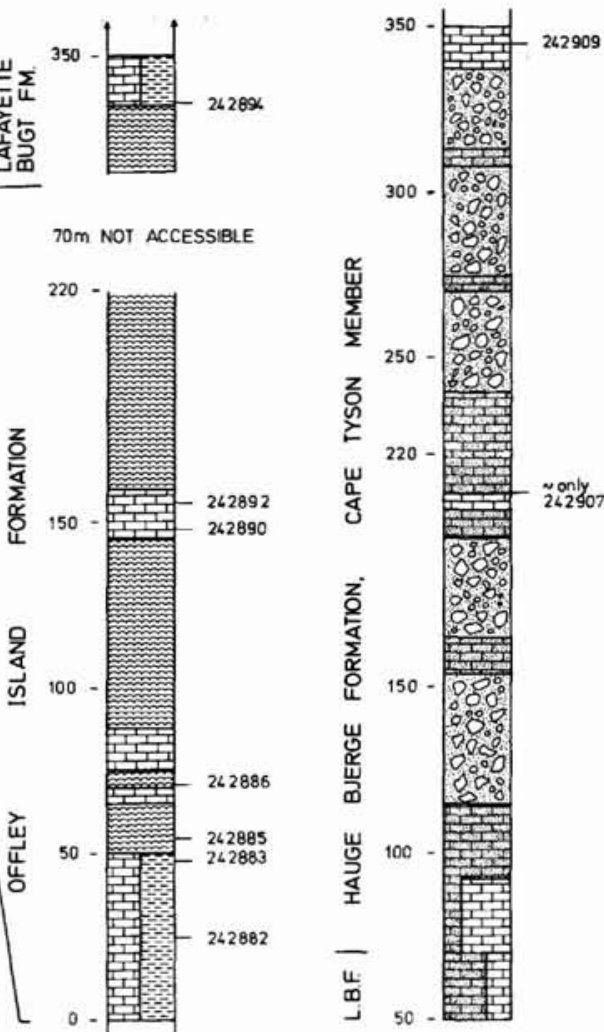

\section{Kap Lucie Marie Formation}

This formation consists of a $25-135 \mathrm{~m}$ thick sequence of faintly laminated mudstones, silty, limy mudstones and, towards the top, graded calcarenites (fig. 19). Graptolites occurring $35 \mathrm{~m}$ above the base of the formation indicate the $M$. spiralis Biozone of late Llandovery age (Bjerreskov, 1981). Samples have not yielded conodonts.

\section{Kap Morton Formation}

The Kap Morton Formation varies in thickness from 150 to $700 \mathrm{~m}$, and mainly consists of massive, light grey, lime mudstones (fig. 19). It was interpreted by Hurst (1980b) as deposited in open shelf to slope environments.

The Kap Morton Formation follows conformably upon the Kap Lucie Marie or Kap Godfred Hansen Formations and is conformably overlain by the Kap Maynard Formation. The presence of Kirkidium (Khodalovechia) sp. in the Kap Godfred Hansen Formation below suggests that the whole of the Kap Morton Formation is post-middle Wenlock in age (Hurst, 1980b).
A low diversity conodont fauna is present throughout the formation, containing mainly coniform species assigned to Dapsilodus obliquicostatus, Decoricornus fragilis, Panderodus recurvatus, $P$. unicostatus $P$. aff. $P$. spasovi, Pseudooneotodus cf. Ps. beckmanni, Ps. bicornis, Ps. tricornis, with elements of $O$. excavata (fig. 16).

\section{Kap Maynard Formation}

This formation consists of dolomites and light grey limestones, mudstones and green, limy shales (Hurst, $1980 \mathrm{~b}$ ) and is up to $200 \mathrm{~m}$ thick (fig. 19). Available conodont samples from Bessels Fjord were barren, but brachiopods assigned to Kirkidium (Kirkidium) sp. by Hurst (1980b) suggest a mid Wenlock to Ludlow age for the lower part of the formation. The upper age limit of the formation is unknown.

\section{Hauge Bjerge Formation}

This formation contains large carbonate mound complexes including core and flank deposits and was divided into two geographically separated members; the Kap 
Independence and Cape Tyson Members by Hurst (1980b).

\section{Kap Independence Member}

This member overlies the Cape Schuchert Formation. Loose blocks of core facies collected in the Kap Independence area (fig. 17) contain a Pterospathodus celloni Biozone fauna. The age span of this member appears to be middle to late Llandovery; there is no internal faunal evidence of a middle Llandovery age but, considering facies relationships, it appears likely that some of the member is of that age.

\section{Cape Tyson Member}

Conodont samples collected at Kap Tyson (fig. 20) were barren. A reconnaissance sample (GGU 82687, Table 10) collected from Kayser Bjerg, Hall Land by P. R. Dawes contains a single Pterospathodus amorphognathoides $\mathrm{Pa}$ element and abundant $P$. pennatus pennatus. This confirms a late Llandovery to early Wenlock age for this member. Graptolites found in a small shale outcrop at the side of a carbonate mound are assigned to the M. spiralis Biozone (Hurst, 1980b; Norford, 1972).

\section{Peary Land Group}

This group was erected by Hurst (1980b) to contain slope and basinal sediments of Silurian - earliest Devonian? age deposited all across North Greenland (Hurst \& Surlyk, 1982). In this paper only the slope deposits of the Cape Schuchert and Lafayette Bugt Formations in the Washington Land - Hall Land area will be dealt with. In Washington Land the Peary Land Group conformably rests on the Aleqatsiaq Fjord Formation and interdigitates with formations of the Washington Land Group: Adams Bjerg, Pentamerus Bjerge, Kap Godfred Hansen and Hauge Bjerge (Kap Independence Member) Formations (fig. 15). In Hall Land the group rests conformably upon the Offley Island Formation, and interdigitates with the Hauge Bjerge Formation (Cape Tyson Member).

\section{Cape Schuchert Formation}

The Cape Schuchert Formation $(55-80 \mathrm{~m})$ is dominated by thin-bedded black, bituminous, cherty limestones and mudstones. Shale beds are common and increase in thickness and abundance upwards. The Cape Schuchert Formation follows conformably upon the Aleqatsiaq Fjord Formation and is conformably overlain by the Lafayette Bugt Formation and the Kap Independence Member of the Hauge Bjerge Formation (fig. 15). Hurst (1980b) suggested that it probably interdigitates with the Adams Bjerg Formation to the south, with the Pentamerus Bjerge Formation to the east and with the Kap Godfred Hansen Formation to the north.

Conodonts from the reference section (fig. 21) are abundant and well preserved, allowing the subdivision of this formation into two conodont biozones, a lower Aspelundia expansa Biozone and an upper Aspelundia fluegeli Biozone. The boundary between the two occurs at approximately $20 \mathrm{~m}$ above the base of the reference section. Associated conodonts are long-ranging, coniform species.

Graptolites collected in the type section were described by Bjerreskov (1981) as part of the $M$. argenteus Biozone (eqivalent to the early Aeronian). This level is equivalent to $10-20 \mathrm{~m}$ above the base of the reference section (J. M. Hurst, personal communication, 1982) and allows independent dating of the $A$. expansa $-A$. fluegeli Biozone boundary. In the type section, graptolites $2 \mathrm{~m}$ above the top of the formation are indicative of the $M$. convolutus Biozone (middle Aeronian, $\mathrm{B}_{2}$ of Jones, 1925). Some $10 \mathrm{~m}$ below the top of the formation in the reference section (fig. 21) graptolites indicative of the $M$. turriculatus Biozone of late Aeronian age were described by Bjerreskov (1981).

The Cape Schuchert Formation is thus apparently of early Aeronian age in the general area of the type locality (although the lower beds may be of Rhuddanian age). Away from this area the formation ranges up into the late Aeronian.

\section{Lafayette Bugt Formation}

The Lafayette Bugt Formation (up to $300 \mathrm{~m}$ exposed) consists dominantly of thick shale units interbedded with poorly-laminated lime mudstones and limestone conglomerate beds, up to $20 \mathrm{~m}$ thick. A thin string of probable stromatoporoid mounds and associated flank breccias at Kap Schuchert were included in this formation by Hurst (1980b).

The Lafayette Bugt Formation conformably follows the Cape Schuchert Formation and interdigitates with the Hauge Bjerge Formation (Kap Independence and Cape Tyson Members), Pentamerus Bjerge Formation and Kap Godfred Hansen Formation (fig. 15). The lower part of the formation yielded a Aspelundia fluegeli Biozone fauna (fig. 21). Standard Pterospathodus celloni Biozone species are present $35 \mathrm{~m}$ above the base, and at $50 \mathrm{~m}$ species indicative of the Pterospathodus amorphognathoides Biozone occur. Graptolites from 
Fig. 21. Generalised section log and conodont ranges for locality 5 (fig. 14) in Washington Land.

For legend see fig. 5.

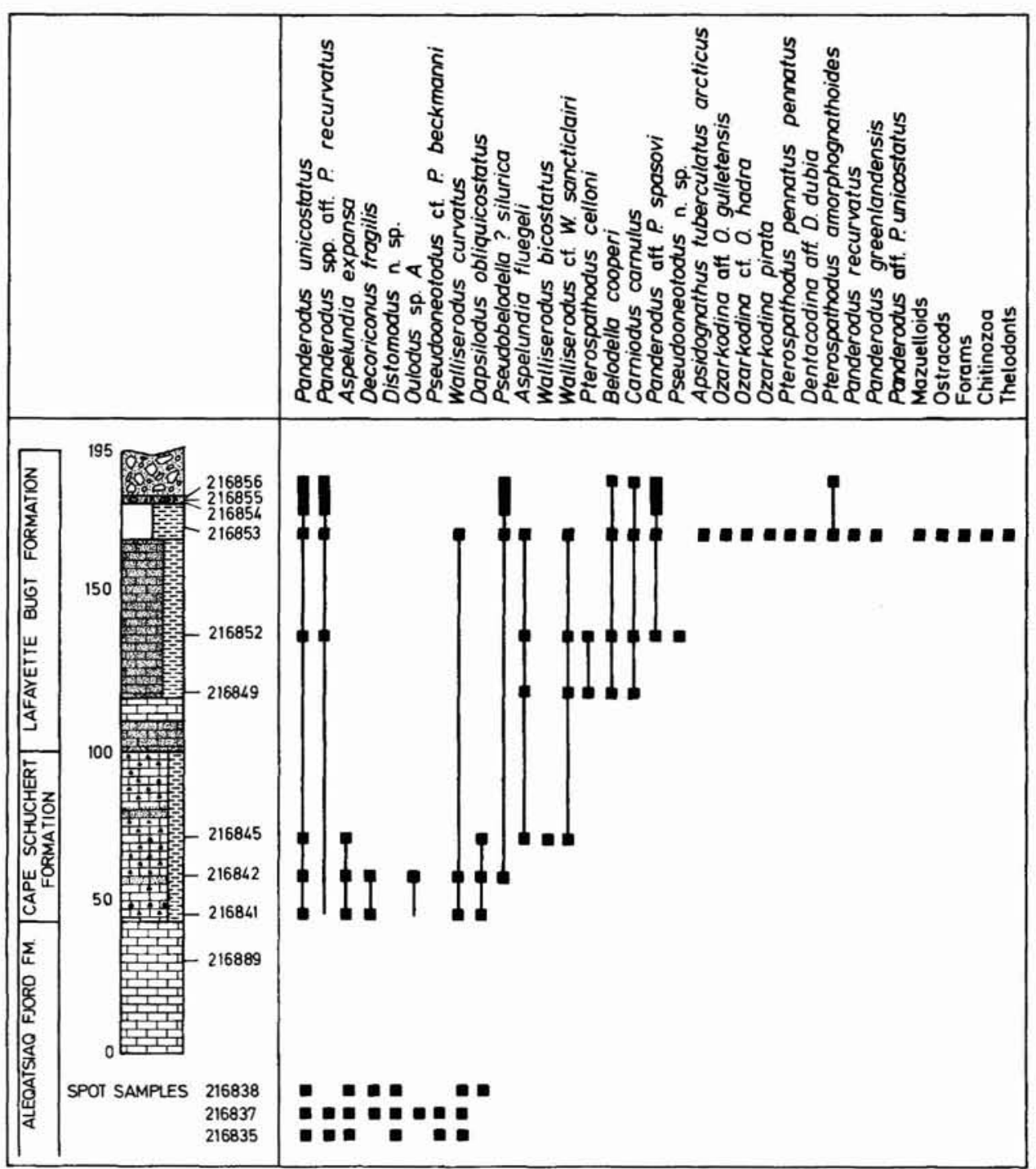

the Lafayette Bugt Formation (Bjerreskov, 1981) indicate a midddle Llandovery age for the base of the formation and an age range from Wenlock up into the Ludlow. The majority of outcrops are of late Llandovery age (Hurst, 1980b).

\section{North Greenland conodont biozones}

The work of Walliser $(1964,1972)$ in the Carnic Alps of Austria stimulated worldwide examination of Silurian faunas, and numerous zonal schemes have since been proposed. These have been assessed and discussed by Cooper (1980, p. 209) who concluded that no simple zonation is at present suitable as a standard reference scheme. He proposed the use of datum planes based on index taxa whose phylogeny is well understood, and whose appearance and extinction can be documented throughout the world.

Cooper (1980) documented only two datum planes in the early Silurian. The Distomodus staurognathoides appearance datum has only been recognised reliably within the Washington Land Group at J. P. Koch Fjord. The Pterospathodus amorphognathoides appearance datum of Llandovery - Wenlock boundary strata is recognised in Washington Land, Valdemar Glückstadt Land and Kronprins Christian Land.

Silurian conodont faunas from North Greenland lack species which have proved biostratigraphically useful in other parts of the world. For example, D. kentuckyensis is absent and D. staurognathoides is rare, both taxa being important in the zonation of American Midcontinent Silurian strata. Icriodella species, important as 


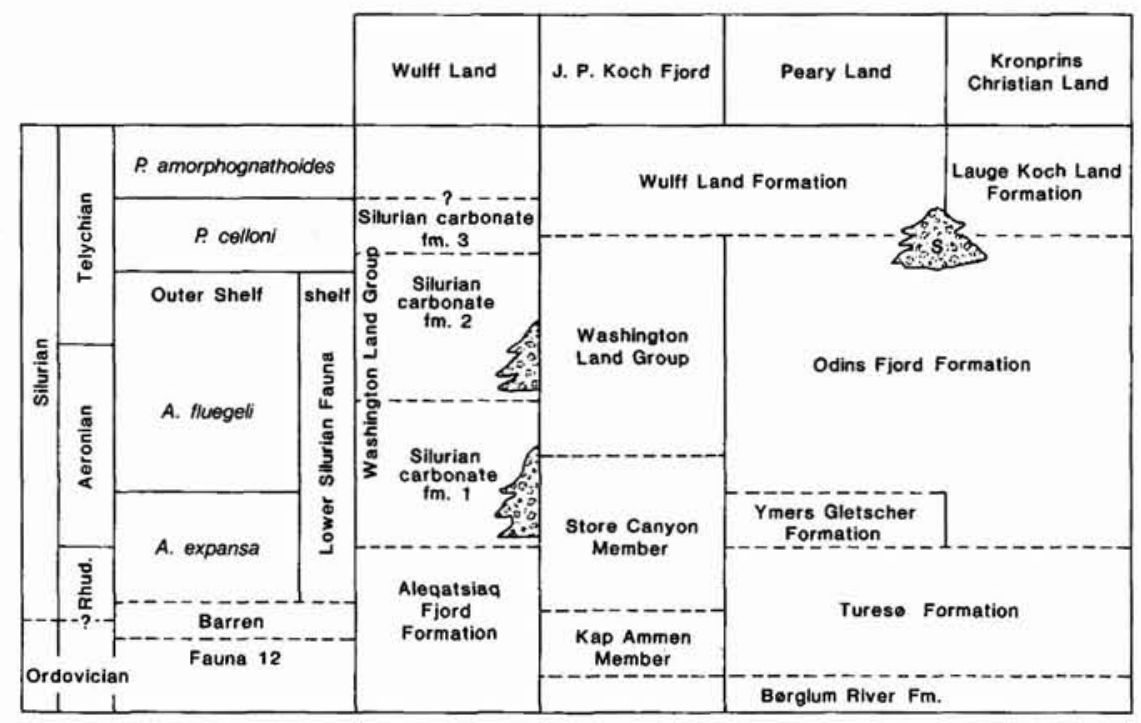

Fig. 22. Summary of section correlation and conodont biostratigraphy in the Wulff Land Kronprins Christian Land region. Carbonate mounds are indicated schematically;

S, Samuelsen Høj Formation.

zonal indices in part of the Welsh Borderland zonation proposed by Aldridge $(1972,1975)$, are also absent. Consequently a local conodont zonation is proposed herein for North Greenland (figs 22, 23).

\section{Late Ordovician - middle Llandovery shelf biofacies}

\section{'Fauna 12'}

A conodont fauna attributable to 'Fauna 12' of Sweet et al. (1971) occurs at the base of studied sections from Wulff Land eastwards to Kronprins Christian Land. The species present are typical of shallow water deposits in the American Midcontinent Province. Sweet (1979) described in detail the Late Ordovician conodonts and conodont biostratigraphy of the western part of the Midcontinent Province, and species ranges are taken from this work. Of the species recorded in Greenland Aphelognathus pyramidalis, Rhipidognathus symmetricus, Drepanoistodus suberectus, Pseudobelodina vulgaris vulgaris, Pristognathus bighornensis and Plegognathus dartoni are restricted to the Richmondian Stage but are, as yet, unknown from strata in the type area (Sweet, 1979). Barnes (1974) also recorded P. dartoni in strata of the Canadian Arctic Islands thought to be Maysvillian-Richmondian in age.

\section{'Lower Silurian Fauna'}

In shelf biofacies the Ordovician-Silurian boundary can be restricted to within $5 \mathrm{~m}$ of strata at J. P. Koch
Fjord. In this area 'Fauna 12' is succeeded by barren strata prior to the first appearance of Ozarkodina hassi. If the first appearance of $O$. hassi provides a reasonable basis for correlation, the underlying barren zone, which occurs throughout Peary Land, may be equivalent in part to the Gamachian Stage as defined on Anticosti Island (McCracken \& Barnes, 1981).

In the shelf biofacies, pre-Pterosphathodus celloni Biozone strata are characterised by Kockelella manitoulinensis, Ozarkodina hassi, O. excavata and Panderodus unicostatus; these species have long ranges from the earliest Silurian. The most common pectiniform element in this biofacies is $K$. manitoulinensis which ranges into the P. celloni Biozone. The presence of Aspelundia expansa and $A$. fluegeli in small numbers in collections from Wulff Land, J. P. Koch Fjord and Kronprins Christian Land allows correlation with strata in the slope biofacies.

\section{Early to middle Llandovery slope and outer shelf biofacies}

The pre-Pterospathus celloni Biozone in this biofacies can be subdivided into a lower Aspelundia expansa Biozone and an upper Aspelundia fluegeli Biozone. The most abundant and characteristic member of each is the nominate species; these occur together with long ranging coniform species.

In Washington Land the earliest occurrence of $A$. expansa corresponds with the base of the Cape Schuchert Formation of slope aspect (fig. 23). It appears close to the Ordovician-Silurian boundary in outer shelf sequences in Wulff Land, at J. P. Koch Fjord and in 


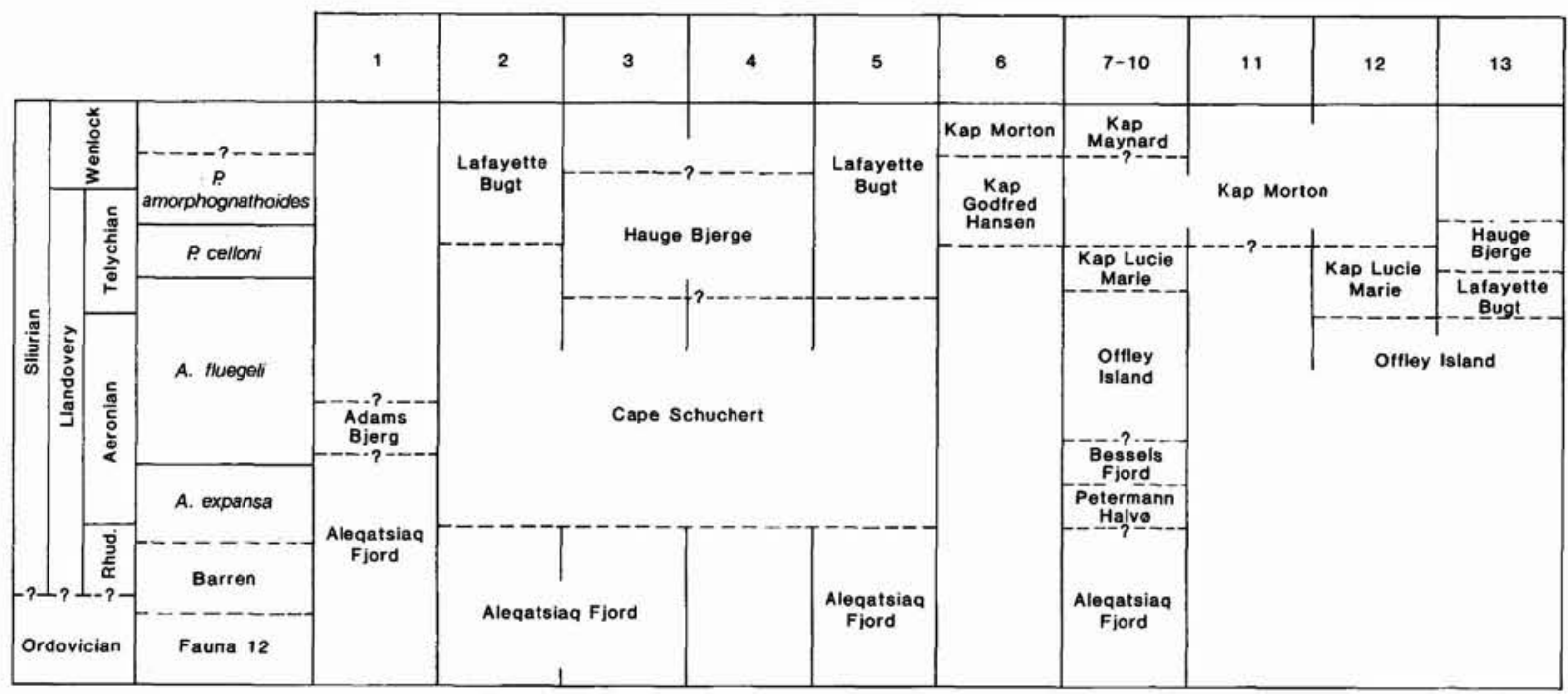

Fig. 23. Summary of section correlation and conodont biostratigraphy Washington Land and Hall Land (localities 1-13 in fig. 14).

Kronprins Christian Land. The upper limit of this biozone is defined at Kap Schuchert (fig. 21) by the first appearance of $A$. fluegeli, an event dated independently by graptolites as lower Aeronian, $B_{1-2}$ of Jones (1925).

The upper limit of the $A$. fluegeli Biozone is defined at Kap Schuchert by the first appearance of $P$. celloni of the $P$. celloni Biozone. The nominate species ranges into post- $P$. amorphognathoides Biozone strata.

\section{Late Llandovery - Pterospathodus celloni Biozone}

The base of this biozone is recognised throughout North Greenland at the first appearance of Pterospathodus celloni. The upper limit is drawn at the appearance datum of $P$. amorphognathoides. At Kap Schuchert $P$. celloni first appears between graptolite assemblages assigned to the $M$. turriculatus Biozone and the $M$. spiralis Biozone (Telychian as defined by Cocks et al., 1984). In east Peary Land Aulacognathus bullatus occurs approximately $10 \mathrm{~m}$ below the first occurrence of $P$. celloni, though elsewhere their first appearances coincide. $A$. bullatus is restricted to the $C_{5}$ subdivision of the Telychian in Britain (Aldridge, 1975) and to the P. celloni Biozone in the Carnic Alps (Walliser, 1964). On Anticosti Island $A$. bullatus occurs beneath the first occurrence of Icriodella inconstans (Uyeno \& Barnes, 1981), a zonal index species confined to the Telychian in Britain where it first appears before $P$. celloni (Aldridge, 1975 , p. 153). A. bullatus is recorded in small numbers almost everywhere and may be of use locally in identifying strata of late Aeronian age in Greenland.

\section{Llandovery-Wenlock boundary - Pterospathodus amorphognathoides Biozone}

The base of this biozone is recognised within the Lafayette Bugt Formation at Kap Schuchert in Washington Land. The nominate species also occurs in the lower part of the Profilfjeldet Member in Valdemar Glückstadt Land and Kronprins Christian Land. The upper limit of the biozone has not been recognised in Greenland.

\section{Comparisons with other early Silurian conodont zonations}

Pre-Pterospathodus celloni Biozone collections from Greenland have little in common with those described elsewhere (fig. 24). At the classic section of Cellon Mountain in the Carnic Alps Walliser (1964) described an all-embracive Bereich I fauna, the exact age of which is uncertain. Serpagli (1967) and Schönlaub (1971) suggested that it was in part late Ordovician in age and Schönlaub (1980) subsequently considered the Ordovician-Silurian boundary to occur within sample 5 of Walliser (1964, pl. 1, Table 2). Conodont fragments assigned to Icriodina irregularis by Walliser (1964) occur in samples $6-8$ but cannot definitely be assigned to the Silurian, as similar specimens from the Upper Ordovician have been figured by Orchard (1980, pl. 1, figs 22, 27). The base of the $P$. celloni Biozone occurs beneath sample 10 allg. of Walliser (1964), an horizon considered by Rexroad (in Craig, 1969) to be an unconform- 


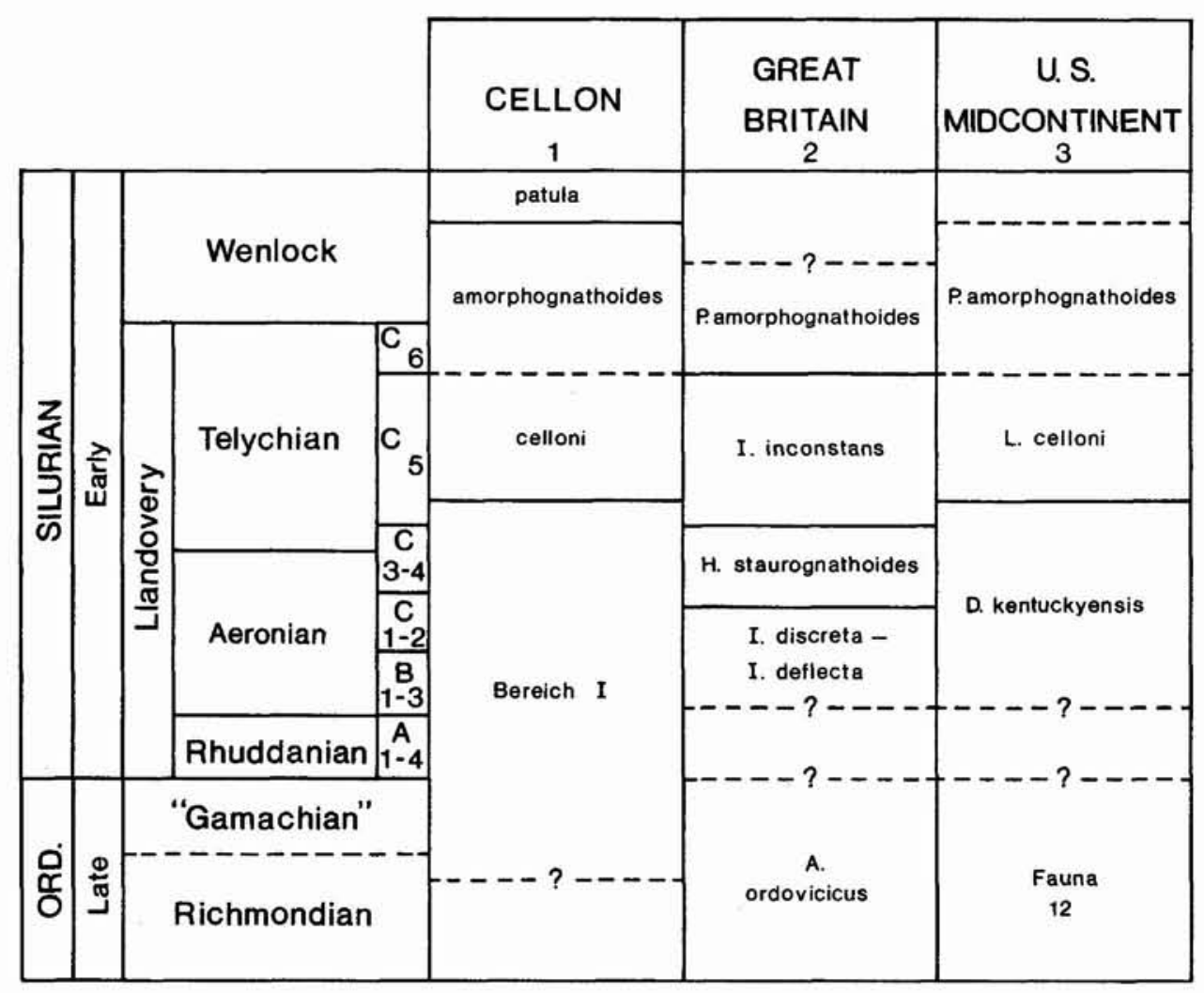

Fig. 24. Approximate relationships between Silurian conodont zonations. 1, from Walliser (1964); 2, in part from Aldridge (1972, 1975); 3, in part from Nicoll \& Rexroad (1969), Pollock et al. (1970), Cooper (1975); 4, from McCracken \& Barnes (1981); 5, from Uyeno \& Barnes (1981). Ordovician conodont zonation from Nowlan (1981).

ity; if this is the case then much of the Llandovery is missing at Cellon.

In Britain, Aldridge $(1972,1975)$ divided pre- $P$. celloni Biozone strata of the Welsh Borderland into three conodont assemblage zones (fig. 24). His Hadrognathus staurognathoides assemblage zone occurs within the late Aeronian and can be correlated with the upper part of the Aspelundia fluegeli Biozone in Greenland (fig. 24). Aldridge (1972) noted few distinctive species present in this assemblage zone apart from the common occurrence of $A$. fluegeli which ranges from older strata in Greenland. He used the Icriodella lineage as the basis for his Llandovery zonation, but Icriodella is absent from the Greenland collections. The $I$. inconstans assemblage zone of Aldridge (1972) is restricted to $C_{5}$ strata in Britain and contains the first appearance of $P$. celloni.

Aldridge (1975, p. 609) reported an Aeronian fauna including Ozarkodina hassi, O. abrupta (questionably a junior synonym of Kockelella manitoulinensis) and $O$. oldhamensis along with $M$. convolutus Biozone graptolites from the Hamperly borehole, Church Stretton, in the Welsh Borderland. Apart from the presence of $O$. oldhamensis this fauna closely resembles the shelf biofacies 'Lower Silurian Fauna' from Greenland.

Lower Llandovery strata from the Oslo graben have yielded a conodont sequence similar to that on Anticosti Island (Aldridge \& Mohamed, 1982) with Distomodus and Oulodus? being common. Ozarkodina hassi is present close to the base of the Silurian, and is considered to be Rhuddanian (O.? nathani Biozone) in age.

A comprehensive study of the conodonts from an apparently continuous upper Ordovician to Silurian (lower Wenlock) sequence on Anticosti Island has yielded large amounts of new information regarding the distribution of conodonts through the Llandovery (Nowlan \& Barnes, 1981). They described a Richmondian conodont fauna (Fauna 12) similar to that in Greenland from the Vaureal Formation. It includes Aphelognathus pyramidalis and Plegagnathus dartoni which Nowlan \& Barnes considered to be typical of nearshore environments. The overlying Ellis Bay Formation contains species in common with Greenland, Drepanoistodus suberectus, Rhipidognathus symmetri- 


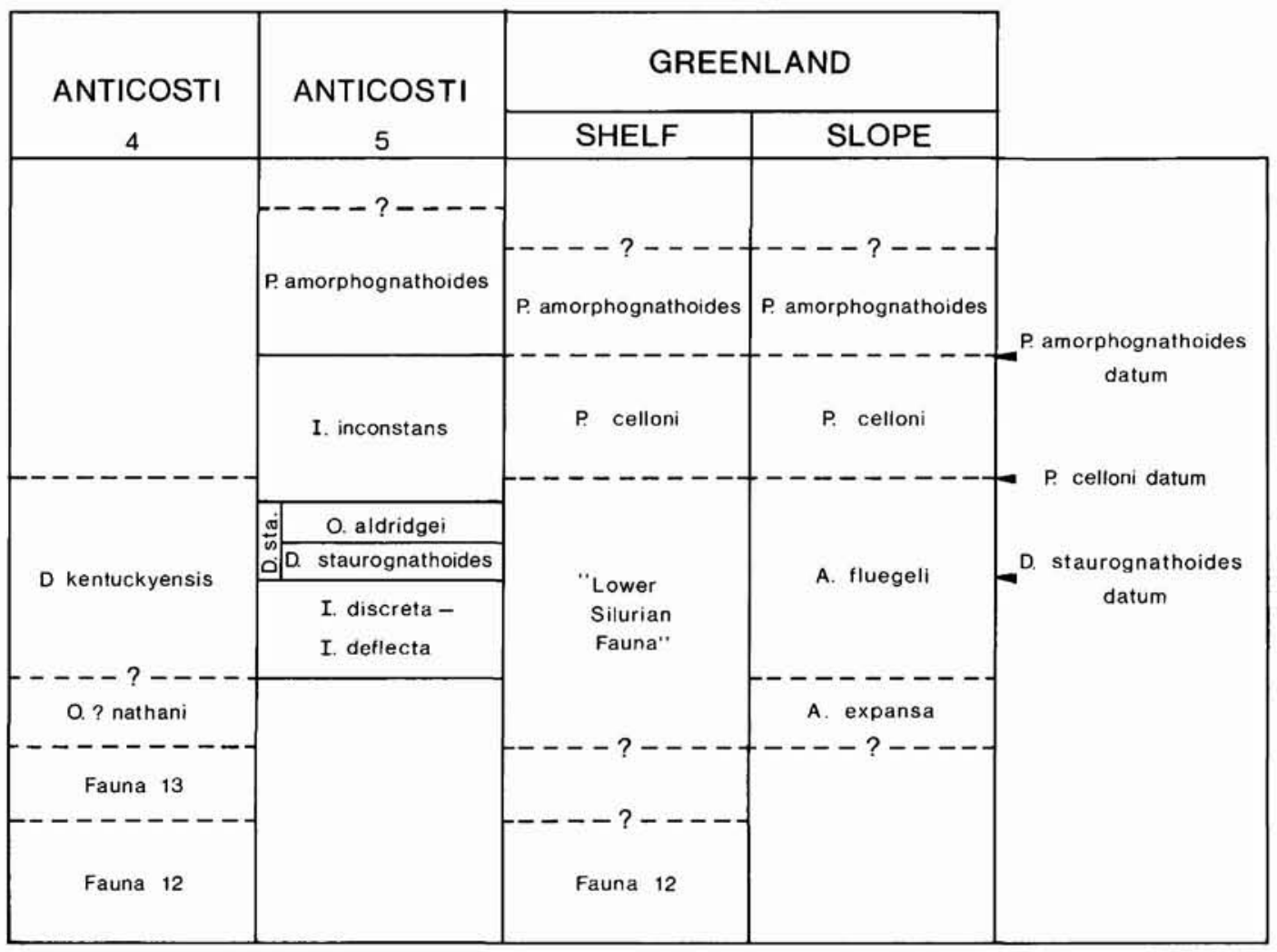

Fig. 24 cont.

cus, A. pyramidalis and various Panderodus species, but it also includes Gamachignathus, a genus not recognised in Greenland (S. Tull, personal communication, 1988). In terms of the informal conodont faunas of Sweet et al. (1971) and Sweet \& Bergström (1971), McCracken \& Barnes (1981) considered the fauna in the Ellis Bay Formation to be significantly different from that in the underlying Vaureal Formation and consequently erected a new Fauna 13, characterised by the presence of Gamachignathus ensifer and G. hastatus.

Sections across the Ordovician-Silurian boundary yielding conodonts are rare. The newly defined stratotype at Dob's Linn (Cocks, 1985) is in graptolitic facies and has not yet yielded age diagnostic Silurian conodonts. On Anticosti Island, however, conodonts are moderately abundant and Barnes \& McCracken (1980) drew the Ordovican-Silurian boundary at the first appearance of Ozarkodina hassi, O. oldhamensis, Oulodus? nathani and Oulodus kentuckyensis. McCracken \& Barnes (1981) erected the O.? nathani Biozone as the lowest conodont zone of the Silurian, and this biozone ranges up into the late Rhuddanian (Nowlan, 1981).
The Distomodus kentuckyensis Biozone, above, ranges from the late Rhuddanian to the Telychian. Based on the occurrence of graptolites in the Greenland sections, it would appear that the Aspelundia expansa-A. fluegeli Biozone boundary lies within the lower part of the $D$. kentuckyensis Biozone.

Other species recorded throughout the Ellis Bay, Becscie and Gun River Formations on Anticosti Island include Icriodella discreta, I. deflecta, Spathognathodus elibatus, Ozarkodina hassi, $O$. oldhamensis and Walliserodus curvatus (Fåhraeus \& Barnes, 1981; McCracken \& Barnes, 1981). The conodont zonations utilised for this part of the section (Uyeno \& Barnes, 1981, 1983) compares closely with that proposed for the Welsh Borderland by Aldridge (1972).

Generally, faunas from the North American Midcontinent are similar to those described from elsewhere. However, Nicoll \& Rexroad (1969) and Pollock et al. (1970) noted differences in faunas from the Cincinnati Arch and north Michigan-Ontario areas of the Midcontinent. The dominant taxon in the former area is Distomodus, and in the latter Icriodella and Ozarkodina 
predominate. The northern area also yields abundant Ozarkodina hassi, O. excavata and Kockelella manitoulinensis and is similar to the shelf biofacies 'Lower Silurian faunas' of Greenland. These authors considered that these differences within the Midcontinent reflected provincialism. Distomodus and Icriodella, however, occur commonly together (e.g. Aldridge, 1972, in the Welsh Borderland), and the occurrence of a diverse Ozarkodina assemblage may be palaeo-ecologically controlled, as suggested by its distribution in Greenland (fig. 26).

Pterospathodus celloni Biozone faunas are widespread. The base of the $P$. celloni Biozone can be well defined in all sections in North Greenland where it provides the best datum for correlation. P. celloni ranges through the late Telychian (see Cooper, 1980, for a review). At Cellon, the $P$. celloni and $P$. amorphognathoides Biozones have mutually exclusive ranges and an unconformity has been suspected between them (Rexroad in Craig, 1969). Elsewhere the ranges of $P$. celloni and $P$. amorphognathoides overlap (Nicoll \& Rexroad, 1969; Craig, 1969).

The Pterospathodus amorphognathoides appearance datum is important in worldwide correlation, occurring in Llandovery-Wenlock boundary strata in Britain (AIdridge, 1972), and in the Carnic Alps (Walliser, 1964; Schönlaub, 1971). Elsewhere in Europe the datum has been located in the Oslo graben (Aldridge, 1974; Aldridge \& Mohamed, 1982), and it is reported from the USSR (Mashkova, 1977, 1979). P. amorphognathoides is also recorded widely in the United States and Canada (refer to Cooper, 1980; Uyeno \& Barnes, 1981; Nowlan, 1981 for recent reviews). The $P$. amorphognathoides Biozone at Cellon extends into the middle Wenlock (Walliser, 1964; Cooper, 1980).

A conodont fauna of post middle Wenlock in the Kap Morton Formation contains predominantly simple cone species which cannot be correlated with coeval sections elsewhere.

\section{Palaeo-ecological observations}

The Greenland collections do not lend themselves to statistical analysis. Sections, particularly from Washington Land, have not been collected systematically, are widely separated and conodont yields are generally less than twenty five specimens per sample. Without the support of statistical comparisons it is difficult to hypothesise about conodont palaeo-ecology, but some major distributional differences within the North Greenland conodont fauna are discussed below. Analysis is restricted to the comparison of conodont distributions (figs 25-27) and diversity changes through time. Previously published interpretations of conodont distri- butional patterns are used to elucidate those found in Greenland.

Late Ordovician faunas from North Greenland are characteristic of the American Midcontinent Province which was close to the equator (Spjeldnæs, 1961; Bergström, 1973). Limestones within this province are often closely associated with extensive evaporite deposits, and Barnes \& Fåhraeus (1975) concluded that late Ordovician seas in this province would have tended towards hypersalinity and increased temperature.

Various shelf communities have been distinguished for the late Ordovician (Barnes \& Fåhraeus, 1975; Le Fèvre et al., 1976); several of these occur in Greenland. Rhipidognathus has been reported in abundance from tidal flat deposits in the Cincinnati Arch area (Kohut \& Sweet, 1968) and in evaporite deposits (Barnes \& Munro, 1973). The monogeneric sample at the base of the Turesø Formation in Kronprins Christian Land may therefore indicate extremely shallow water.

Plegagnathus, Drepanoistodus, Oulodus, Rhipidognathus and Panderodus are widespread in North Greenland. They are common genera in shallow, subtidal deposits (Barnes \& Fåhraeus, 1975) and appear to have formed a widespread 'shelf' community.

On limited data, the association of Walliserodus, Pristognathus and Pseudobelodina at Odin Fjord and J. P. Koch Fjord may represent a deeper shelf community in Greenland.

Two regressive-transgressive cycles were documented in Upper Ordovician strata from the Hudson Bay Basin by Barnes \& Fåhraeus (1975). The second regressive phase (resulting from the late Ordovician Gondwana glaciation during the latest Ordovician) is recorded elsewhere in the world (Berry \& Boucot, 1973) and resulted in widespread extinction within the Conodonta. The North Greenland conodont fauna underwent a major crisis, with only a few coniform genera continuing into the Silurian. Currently, the only diverse conodont faunas described from this interval ('Gamachian') are from the deeper water sediments of the Gaspé Peninsula (Nowlan, 1981) and Anticosti Island (Nowlan \& Barnes, 1981).

Conodonts during the early Silurian were generally low in abundance and diversity. During this time a well defined nearshore community comprising Icriodella, Distomodus and Ozarkodina species existed (Aldridge, 1976; Le Fèvre et al., 1976). This may in part correlate with the shelf biofacies in Greenland; but major differences in the assemblage (absence of Icriodella and Distomodus) suggest that either these taxa did not reach Greenland until later in the Silurian or that environmental conditions were somewhat different from those in Europe and Canada. The closest correlative to the 

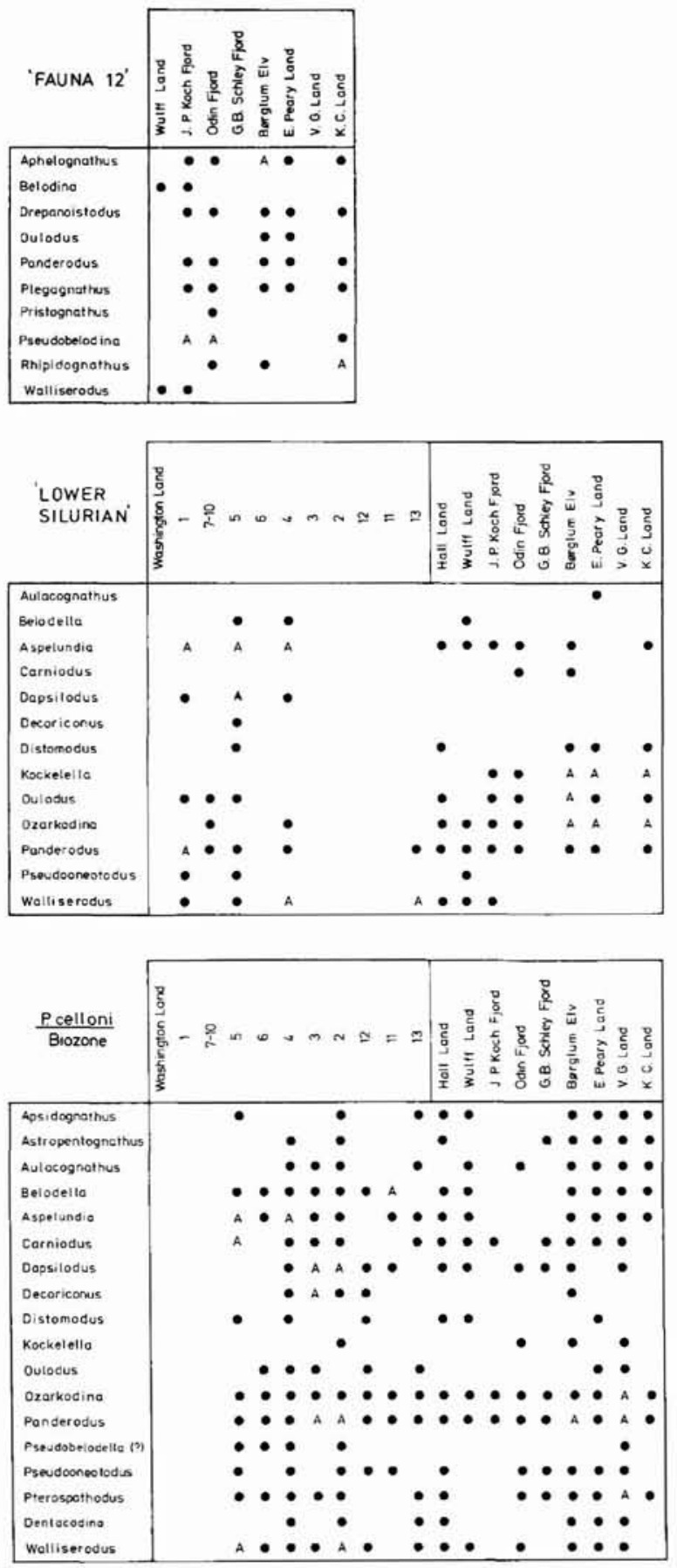

Fig. 25. Geographical and stratigraphical distribution of conodont genera in North Greenland. A, abundance greater than $25 \%$ of conodont fauna.

shelf biofacies in Greenland may be found in the fauna of the Manitoulin Island dolomites of Canada (Pollock et al., 1970). In possibly more outer shelf sequences at $\mathrm{J}$.
P. Koch Fjord and Kronprins Christian Land, a shelf biofacies fauna of simple cones and diminuitive Ozarkodina species dominate lower to middle Llandovery strata. In Wulff Land an apparent mixture of shelf and slope genera occurs (fig. 25).

The slope biofacies of lower-middle Llandovery age, represented at Kap Schuchert, yields prolific, low diversity conodont faunas containing Aspelundia, Dapsilodus and Decoriconus almost to the exclusion of other genera. A similar biofacies has not previously been described, although Aldridge \& Mabillard (1981) documented the preference of Dapsilodus and Decoriconus for shelf margin to slope environments in the Welsh Borderland. The Pterospathodus celloni Biozone from Greenland contains cosmopolitan species (fig. 25), suggesting uniform environmental conditions for eurytopic species.

Aulacognathus, Astropentagnathus and Apsidognathus are relatively more abundant in Greenland than in the majority of described Silurian collections, but the significance of this observation is obscure. Similar abundances occur, however, in the Lee Creek Member of the Brassfield Limestone (Nicoll \& Rexroad, 1969) and in Silurian collections from Ellesmere Island (Mirza, 1976). Coniform species are particularly abundant and diverse in the Greenland collections.

Pterospathodus celloni Biozone strata in other parts of the world witness the rapid increase in abundance and diversity of the Conodonta, and this increase is also readily distinguished in Greenland (fig. 27). Le Fèvre $e t$ al. (1976) considered the increase on the American midcontinent to be the result of migration of 'European' conodonts into the area which reflected the establishment of more open marine conditions. A European ancestral stock for many of the species recorded cannot be discounted; but it is difficult to conceive how the virtually instantaneous worldwide migration of these species into shelf habitats could have been accomplished unless all had a pelagic mode of life. An alternative hypothesis is that this fauna originally occupied slope or deeper shelf (lower salinity, cooler water) environments and subsequently migrated into shelf environments as the result of worldwide transgression.

A distinct littoral biofacies comprising Icriodella, Ozarkodina, Distomodus and Lonchodina has been documented from P. celloni Biozone strata (Aldridge, 1976) though this is not present in Greenland.

Coniform species are abundant and diverse throughout the Llandovery in Greenland and show apparent increase in diversity (fig. 27) during the P. celloni Biozone. This is mirrored in coeval strata in the Welsh Basin (Mabillard \& Aldridge, 1985). 


\section{EARLY SILURIAN}

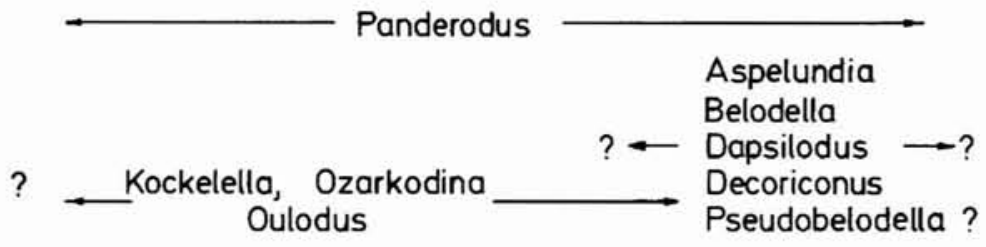

FAUNA 12

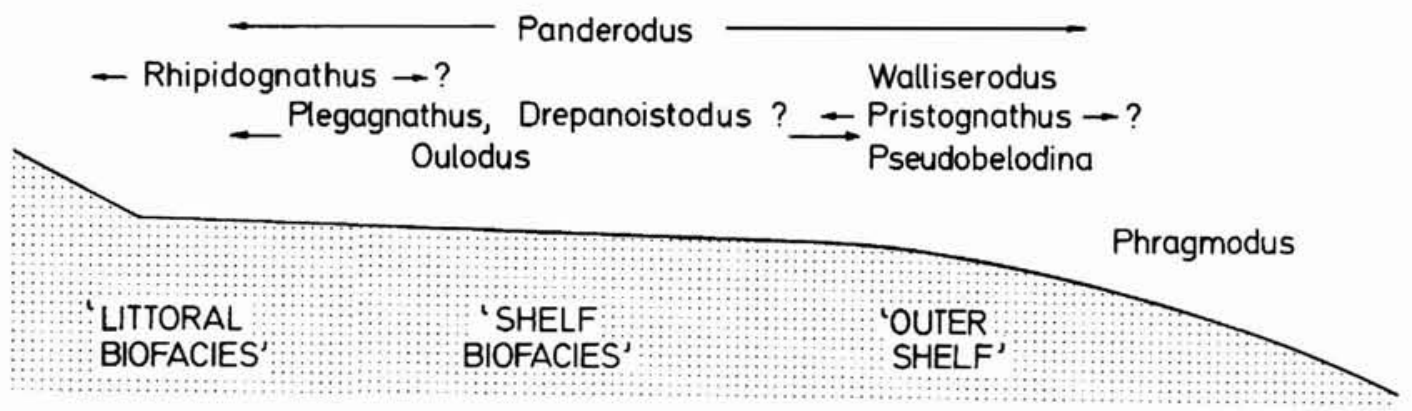

Fig. 26. Generalised palaeoecological distribution of conodont genera in North Greenland during the late Ordovician (Fauna 12) and early Silurian.

\section{Diversity trends}

A method of comparing the relative diversity of samples containing a variable number of individuals from a randomly sampled population is provided by an index formulated by Fisher et al. (1943):

$$
\mathrm{S}=\mathrm{a} \log \mathrm{e}(1+\mathrm{N} / \mathrm{a})
$$

$\mathrm{S}$ is the number of species, $\mathrm{N}$ the number of individuals, and $\mathrm{a}$ is the index of diversity. The number of individuals within each species is not taken into account (Aldridge, 1976). In the present context measurement of conodont diversity is based entirely on multi-element species; changes in diversity are plotted in fig. 27. In all but the shelf biofacies at Børglum Elv in southern Peary Land and the slope biofacies at Kap Schuchert, the specimen abundances are too low to allow separate calculation for ramiform and coniform genera. Where possible, samples from each lithostratigraphical member or formation have been grouped to increase the effective sample size. At Kap Schuchert specimen abundances per sample are large enough to trace diversity trends between each sample. The low specimen abundances in Wulff Land, at J. P. Koch Fjord and at Odin
Fjord may in part reflect low sample sizes rather than palaeo-ecological factors.

Diversities measured in Upper Ordovician samples are moderately high and compare with the values for Pterospathodus celloni Biozone strata. In the Børglum Elv area of southern Peary Land and Kronprins Christian Land diversity decreases through the Tures $ø$ Formation reaching a low in the upper part of the formation. Above this, diversity increases only gradually. Typical of this part of the succession are occasional samples with high yields (e.g. GGU 228901, fig 6, Table 1). Le Fèvre et al. (1976) recorded a similar low diversity with occasional prolific horizons which they related to oscillation between intertidal (low diversity) and peri-reefal/subtidal conditions (higher diversity). Comparable environmental oscillation may account for variation in conodont abundance also in the Odin Fjord Formation.

The slope biofacies in Washington Land also displays a reduction in diversity within the upper Aspelundia expansa Biozone; this correlates with the reduction in the upper parts of the Tures $ø$ Formation in Peary Land. At Kap Schuchert, however, the fall in diversity is due to a massive increase in the number of specimens of Dapsilodus obliquicostatus which may represent the 
Fig. 27. Changes in conodont diversity through time at Børglum Elv and Kap Schuchert.
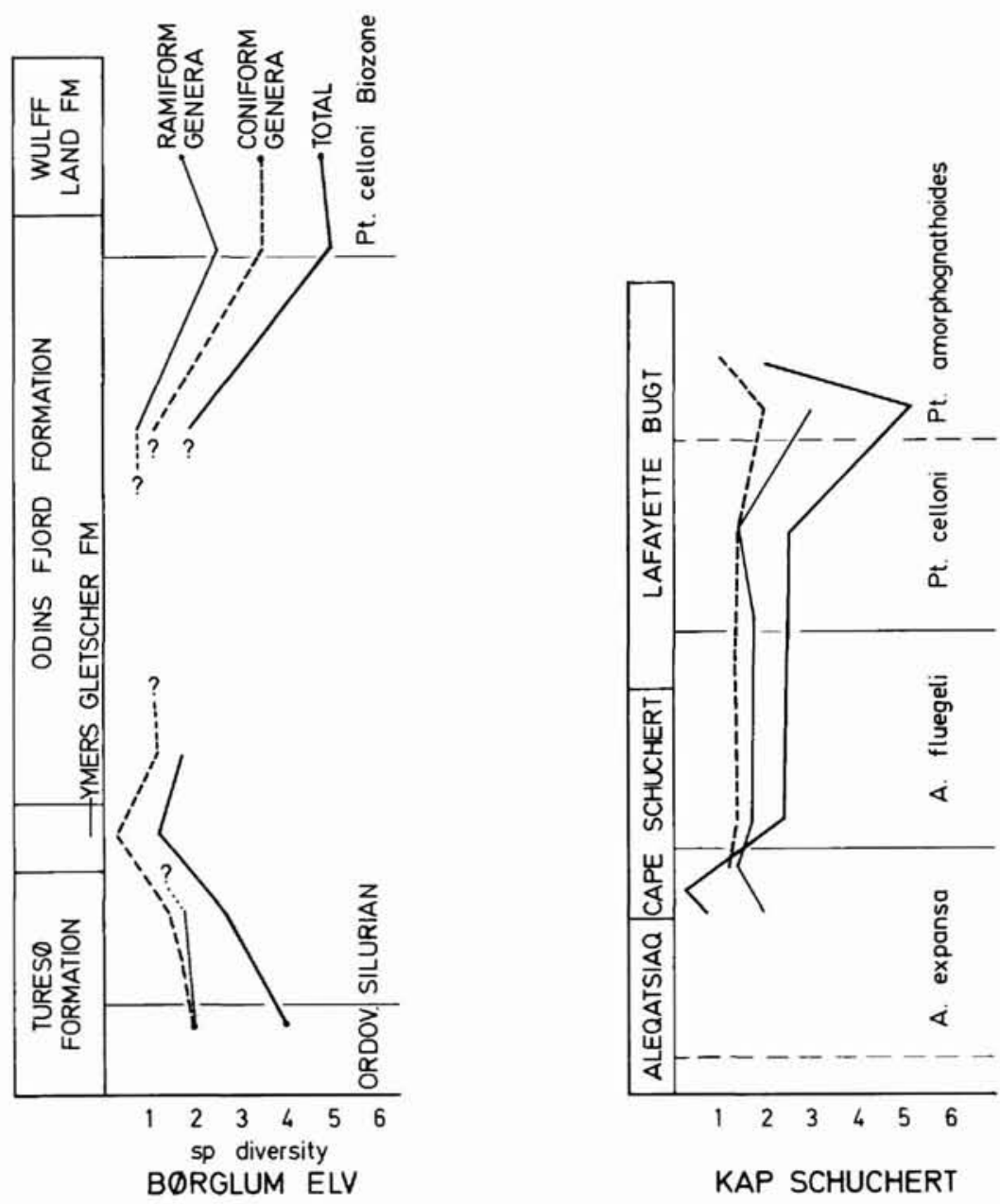

temporary colonisation of the area by a low diversity, specialised, deeper water community. Diversity throughout the $A$. fluegeli Biozone remains constant at Kap Schuchert, with values comparable to those in coeval strata in Peary Land.

The late Ordovician worldwide regression has been correlated with the Gondwana glacial event (Berry \& Boucot, 1970; McCracken \& Barnes, 1981, for a review). The resultant shallowing would have led to a fall in the number of shelf habitats and a fall in species diversity. The diversity trend in the Turesø Formation mirrors this, with the reduction continuing into the earliest Silurian. Following the regression and mass extinctions the shelf fauna might be expected to be of low diversity, comprising a restricted number of opportunistic species, and a stable environment would inhibit rapid diversification (Valentine, 1973). The general similar- ities between the diversity values in shelf and slope biofacies would initially suggest that the late Ordovician extinction event affected the whole conodont fauna.

The increase in diversity at the base of the Pterospathodus celloni Biozone is more difficult to interpret. Other authors have noted that there is no evidence for increased conodont diversity with depth (Aldridge, 1976; Barnes \& Fåhraeus, 1975). Similarly, Aldridge (1976) noted no general correlation between diversity and lithology though, in some situations, lithological changes may be concurrent with changes in conodont faunal composition and diversity. Coniform genera, however, show increased abundance in offshore environments in Greenland, supporting the postulation of Seddon \& Sweet (1971), Aldridge (1972) and Barnes \& Fåhraeus (1975) that distribution patterns may be correlated with water-depth related factors. 


\section{SYSTEMATIC PALAEONTOLOGY}

\section{Conodont element terminology}

\section{Ramiform genera}

The application of a more biological multi-element taxonomy has led to the development of a large number of notational schemes relating element shape and morphology to presumed position in the conodont apparatus (Sweet, 1981b, pp. W17-20). The notational scheme proposed by Sweet \& Schönlaub (1975) modified by Cooper (1975), is adopted in this study as it is the most widely used amongst Silurian conodont workers. Apparatuses containing more than the standard six elements occur in the Greenland section e.g. Astropentagnathus and Aspelundia. Distinct multiple pairs of elements in this type of apparatus, which apparently occupied similar locations, are denoted by subscripts, e.g. $\mathrm{Pa}_{1}$ and $\mathrm{Pa}_{2}$. The major shape categories and morphological terminology employed herein are as described by Sweet (1981b).

\section{Coniform genera}

There is at present no widely accepted descriptive terminology for homologous elements within coniform multi-element apparatuses. Prior to the work of Barrick (1977) few attempts were made to reconstruct Silurian coniform apparatuses. Cumbersome generically derived terminology, applied at that time to many non-coniform apparatuses, was adapted for use with coniform taxa (Lindström, 1964, 1971; Bergström \& Sweet, 1966). This terminology had many problems associated with it (Barrick, 1977) and has largely been abandoned.

In an attempt to make coniform apparatus nomenclature more 'natural' Barrick (1977) applied the national scheme proposed by Sweet \& Schönlaub (1975). This assumed the elemental positions in coniform and nonconiform apparatuses are directly comparable, which cannot be confirmed. The system also demands easily recognisable elemental positions within and between apparatuses. Inadequately known coniform 'bauplans' and intergrading element morphotypes cannot be adequately classified with this system. In addition, until the apparatuses of coniform and non-coniform genera can be shown to have analogous functions and similar origins, a separate notational system is advocated.

Barnes et al. (1979) classified coniform apparatuses into 'types' based upon the degree of elemental upperlower compression, cross-sectional symmetry and curvature (fig. 28). This scheme is preferred as it is flexible, it highlights homologous elements, which leads to a greater understanding of phylogeny and may lead to a 'natural' supragenetic classification.

The Greenland collections contain a large number
A. Panderodus

\begin{tabular}{|c|c|c|c|}
\hline Barrick (1977) & Sweet (1979) & Barnes et al (1979) & Greenland \\
\hline S a & similiform & $p$ & sym.p \\
Sb & asimiliform & & aq \\
Sc & arcuatiform & & $r$ \\
M & falciform & $q$ & sq \\
& tortiform & & tp \\
\hline
\end{tabular}

B. Walliserodus

\begin{tabular}{|l|c|c|c|c|}
\hline Form taxa & Cooper (1975) & Barrick (1977) & Barnes et al (1979) & Greenland \\
\hline P dyscritus & costate el & Sa & $\mathrm{u}$ & symp \\
P debolti & costate el. & $\mathrm{M}$ & $? \mathrm{t}$ & ap \\
A. unicostatus & acodiform & Sd & $\mathrm{t}$ & aq \\
A. curvatus & costate el. & $\mathrm{Sc}$ & $\mathrm{s}$ & sq \\
P. migratus & costate el. & \multicolumn{2}{|c|}{ Not previously described } \\
\cline { 2 - 3 } & \multicolumn{3}{|c}{} \\
\hline
\end{tabular}

Fig. 28. Apparatus nomenclature applied to Panderodus and Walliserodus. 


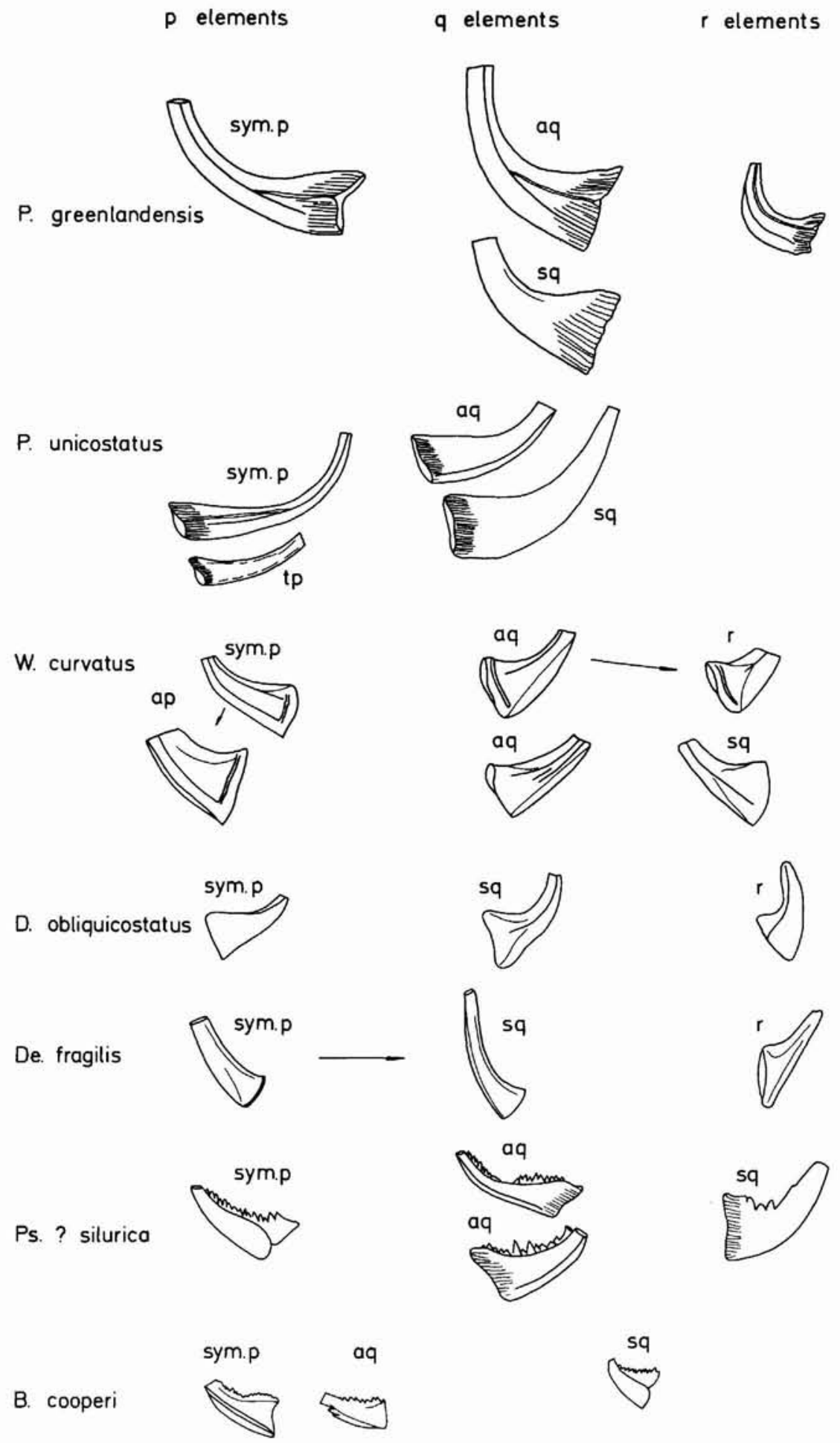

Fig. 29. Homologies between elements of coniform conodont genera encountered in the Greenland collections. Arrows indicate symmetry transition with intermediate forms. 


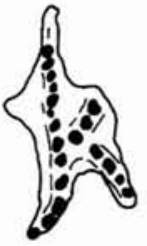

$\mathrm{Pa}_{1}$

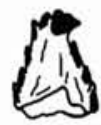

M

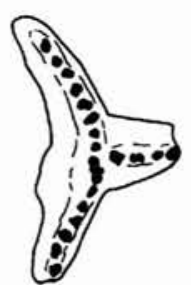

$\mathrm{Pa}_{2}$

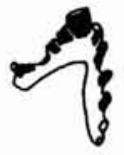

$\mathrm{Sb}$
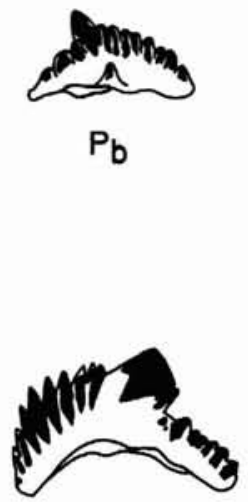

Sc
Fig. 30. The apparatus of Astropentagnathus irregularis irregularis Mostler. The shaded area represents the distribution of white matter. All figures are camera lucida drawings of the numbered specimens, $\times 30$ unless otherwise stated. $\mathrm{Pa}_{1}$, MGUH 17.632; $\mathrm{Pa}_{2}$, MGUH $17.633 \times 20 ; \mathrm{Pb}$, MGUH 17.634; M, MGUH 17.636; Sb, MGUH 17.638; Sc, MGUH 17.639.

and variety of coniform elements, and early in this study it was found that the morphological variation between the elements of a single apparatus could not be adequately covered by the simple $\mathrm{p}, \mathrm{q}$ and $\mathrm{r}$ notation of Barnes et al. (1979). Modification of the scheme as outlined below solves this problem and is applicable to all Silurian coniform taxa (fig. 29).

Erect elements with a long base and short proclined cusp ( $p$ elements) can be subdivided into symmetrical $p$ elements (sym. p) which are more or less bilaterally symmetrical and commonly develop antero-lateral and postero-lateral costae; asymmetrical p elements (ap) which are asymmetrical with respect to the location of the inner-lateral costa or costae; twisted p elements (tp; the tortiform element defined by Sweet, 1979), in which the cusp is laterally twisted with respect to the base, are commonly upper-lower compressed with a lenticular cross-section. This element has only been recorded rarely from the Panderodus apparatus.

From the more strongly recurved $q$ elements two shape categories can be distinguished. Symmetrical q elements (sq) which are laterally compressed and have a cusp with a lenticular cross-section. Asymmetrical q elements (aq) which are strongly asymmetrical, commonly bearing only a single inner-laterally directed costa on the lower edge. This element is generally the most abundant and exhibits the greatest intra-elemental variation.
The highly recurved r elements are commonly morphologically transitional from the aq element by increased curvature of the cusp, costa distribution is also similar. This shape category in all Silurian genera (except Panderodus) is acodontan in style, rather than oistodontan as found in Upper Ordovician coniform apparatuses.

The elemental notation employed in this study does not presuppose a locational position within an apparatus. Very few coniform natural assemblages are known (Aldridge, 1982) and the apparatus structure of many is poorly understood. Ratios of elements within a single apparatus suggest that multiple pairs of each element category may have occurred, for example ratios of elements in Dapsilodus obliquicostatus from Greenland are $p, 1: q, 10: r, 5$. This suggests that as many as 32 single elements may have occurred within the $D$. obliquicostatus apparatus. Aldridge (1982) described a coniform cluster Besselodus arcticus from the Upper Ordovician which contained several sq elements and one $r$ element. Close study of this cluster shows the sq elements to differ slightly in minor detail, i.e. slight difference in the twisting and inclination of the cusp or slightly different positions of the lateral costae, characters also seen to differ in large collections of discrete elements. The significance of such minor changes cannot adequately be assessed until additional clusters are isolated. If found to be significant, these differences can be accommodated in the proposed scheme by the use of subscripts.

Denticulate coniform genera from the Ordovician, Pseudobelodina Sweet (1979) and Plegagnathus Ethington \& Furnish (1959) are described using the nomenclature of Sweet (1979). Pseudooneotodus Drygant (1974c) cannot be described using existing nomenclatural schemes, and a descriptive morphological terminology is applied to the elements of its apparatus.

It is considered somewhat premature to firmly accept any familial classification (Clark, 1981) before a fuller understanding of apparatus structure and phylogeny of coniform genera can be achieved. Using the modified Barnes scheme it is possible to compare directly the apparatus structures of lower Silurian coniforms which may form the basis for a suprageneric classification.

Attempts have been made to study all relevant holotypes, though this was not always possible. Where available, topotype material within the University of Nottingham, Department of Geology, Micropalaeontology Unit collections has been examined to support taxonomic conclusions.

Synonymy lists for Silurian species are comprehensive and annotated as recommended by Matthews (1973, after Richter, 1948). Ordovician collections are small and synonymy lists for these species have been short- 
ened to include: the original species designation; any subsequent important taxonomic changes; the most recent full synonymy list.

\section{Silurian conodont systematic palaeontology}

\section{Genus Apsidognathus Walliser, 1964}

1964 Apsidognathus 1964, p. 29.

1964 Astrognathus 1964, p. 30.

Type species. Apsidognathus tuberculatus Walliser, 1964 , p. 29.

Emended diagnosis. Apparatus comprised of a broad pastiniscaphate platform element, with variable platform ornament; a lenticular element with an inner-laterally extended platform and reduced or absent outer platform; an anguliscaphate ambalodontan element; a cruciform, astrognathodan element with a narrow laterally restricted basal cavity; a strongly arched and highly characteristic lyriform element; a laterally compressed element and a coniform element which develops short rudimentary lateral processes and a costa on the posterior edge.

Remarks. All elements are distinctive and species are characterised particularly by the variable ornament of the platform element and the shape and ornament of the lyriform element.

Apsidognathus contains similar elements to the $\mathrm{Pa}_{1}$ and $\mathrm{Pa}_{2}$ elements of Astropentagnathus (plate 3, figs 1-2); the platform develops multiple inner and outer processes and the lenticular element with a single lateral process. The ambalodontan element of Apsidognathus can be homologised with the $\mathrm{Pb}$ element of Amorphog. nathus (sensu Bergström, 1971, p. 132, fig. 13, N-T) though sinistral and dextral morphotypes are identical in Apsidognathus. The M elements in Amorphognathus and Astropentagnathus and the coniform element of Apsidognathus are tertiopedate and develop rudimentary lateral processes; additionally all three are rare in known collections. Assuming these similarities represent true homologies in the platform complex of these genera the remaining elements should represent the ramiform complex. In order to understand the possible homologies of these elements an a priori decision as to the location of the astrognathodan element has to be made. This element is bilaterally symmetrical and quadriramate and could occupy either the Sa or Sd positions in the apparatus. If the former is correct, then the logical homology would be to have the lyriform as the
$\mathrm{Sb}$ and the compressed element equivalent to the $\mathrm{Sc}$ element. The direction of compression thus changes between $\mathrm{Sb}$ and $\mathrm{Sc}$ elements, a feature of the symmetry transition series in better known apparatuses.

If the astrognathodan, however, represents the Sd element in a ramiform complex similar to that of Amorphognathus, it is then likely that the lyriform element either occupied both $\mathrm{Sa}$ and $\mathrm{Sb}$ positions or that no Sa element has yet been found. It is pertinent to note that the squat conical element of $A$. ruginosus (sensu Mabillard \& Aldridge, 1983) is bilaterally symmetrical and may be the Sa element of this species. As currently perceived Apsidognathus could have an apparatus plan intermediate between that of Amorphognathus and Astropentagnathus, having the platform structure of the latter and the ramiform structure of the former.

\section{Apsidognathus tuberculatus tuberculatus Walliser, 1964}

Plate 1, figs $12-16$; plate 2 , figs $1-4$

1962 n. gen B n. sp. Walliser, p. 282, fig. 1, no. 4.

v*1964 Apsidognathus tuberculatus Walliser, p. 29, pl. 5, fig. 1 ; pl. 12 , figs $16-22$; pl. 13 , figs $1-5$.

v1964 Ambalodus galerus Walliser, p. 27, pl. 6, fig. 1; pl. 12, figs 1-7.

v1964 Astrognathus tetractis Walliser, p. 30, pl. 5, fig. 4 ; pl. 14 , figs 1,2 .

v1964 Pygodus lyra Walliser, p. 68, pl. 5, fig. 5; pl. 12, figs 8-14.

v1964 Pygodus lenticularis Walliser, p. 67, pl. 4, fig. 17; pl. 12, fig. 15.

1965 Apsidognathus tuberculata; Brooks \& Druce, p. 375 , pl. 1 , figs $1,9,10$.

v1969 Apsidognathus tuberculatus; Nicoll \& Rexroad, p. 24 , pl. 3 , fig. 8 .

1970 Apsidognathus tuberculatus; Moskalenko, pl. 1, figs $4,5,6 a, 6 b$.

1970 Pygodus lyra; Moskalenko, pl. 1, figs 9, 10.

1970 Ambalodus galerus; Moskalenko, pl. 1, fig. 3.

1971 Astrognathus tetractis; Schönlaub, p. 46, pl. 2, fig. 15 .

1971 Pygodus lenticularis; Schönlaub, p. 48, pl. 2, figs $13,14$.

v1972 Apsidognathus tuberculatus; Aldridge, p. 165, pl. 2 , figs 7,9 .

v1972 Ambalodus galerus; Aldridge, p. 166, pl. 3, figs 6,8 .

v1972 Astrognathus tetractis; Aldridge, p. 166, pl. 3, fig. 1 .

v1972 Pygodus? lyra; Aldridge, p. 210, pl. 3, fig. 2.

v1975 Apsidognathus tuberculatus; Aldridge, pl. 1, figs 1,2 .

v1975 Ambalodus galerus; Aldridge, pl. 3, fig. 9.

v1975 Pygodus? lenticularis; Aldridge, pl. 3, figs 22, 23.

1980 Apsidognathus tuberculatus; Helfrich, pl. 1, figs $25,29$.

1981 Apsidognathus tuberculatus; Nowlan, pl. 7, figs 7, 12-14, figs 7, 12-14, 17.

1981 Apsidognathus tuberculatus; Uyeno \& Barnes, pl. 1, figs 14-17.

1983 Apsidognathus tuberculatus; Nowlan, figs 4A, 4B.

1985 Apsidognathus tuberculatus; Aldridge, pl. 3.2, figs $20-24$. 
1985 Apsidognathus tuberculatus; Savage, p. 715, figs $5 \mathrm{~A}-\mathrm{N}$.

p1986 Apsidognathus tuberculatus tuberculatus; Bischoff, p. 150 , pl. 1 , figs $1-7,11-13,22,25-28$; pl. 2 , figs $1-4$.

1987 Apsidognathus tuberculatus; Over \& Chatterton, pl. 4 , figs $8, ? 9,10-14,20, ? 21$.

Holotype. Apsidognathus tuberculatus Walliser, 1964, p. 28, pl. 5, fig. 1; pl. 12, fig. 18. Pa element from Cellon, layer 10D, Carnic Alps, Austria.

Emended diagnosis. The lyriform is diagnostic of the apparatus and has a short free anterior blade, its posterior platform is flattened-oval in outline with a straight posterior margin. The anterior and lateral platform margins are raised and bear an ornament of reticulate or transverse rugae. The platform element has a short free blade and nodose ridges which radiate from the centre of the element.

Description. Platform element. Falls within the range of morphology illustrated by Walliser (1964, pl. 13, figs 1, 2).

Lyriform element. Arched, planate element which is more or less bilaterally symmetrical longitudinally. Anterior free blade is short and slender, triangular in upper view with a reticulate ornament of low, sinuous rugae. A transverse ridge or swelling may separate the free blade from the main platform. The platform is narrow and has rounded anterior 'shoulders'; it flares towards the posterior and may be slightly inwardly curved. Its upper surface displays raised marginal ridges which bear an ornament similar to that of the free blade. The ornament extends for approximately two-thirds of the length of the platform. Centrally the platform has a broad depression which is narrow anteriorly and broadens rapidly towards the posterior. The lateral faces of this depression are shallowly concave to convex and are unornamented. Towards the posterior a low medial ridge may be developed; this can extend up to the midlength of the platform. The posterior margin is smoothly concave when this medial ridge is absent, often indented when it is present.

In lower view the undersides of the marginal ridges are steeply inclined upwards and inwards. The basal cavity is restricted to a broad groove in the centre of the lower surface. It is deeply excavated, and surrounded by a narrow raised zone of recessive basal margin. Anteriorly the cavity terminates beneath the junction of the free blade and the platform, though the lower surface of the former may be shallowly excavated; posteriorly the basal cavity extends almost to the posterior margin of the element. Commonly the cavity is partially infilled with a thin layer of basal material, in these specimens the posterior eighth of the cavity is completely infilled and the remaining basal material develops a narrow slit-like depression in its lower surface (plate 2, fig. 2).

Ambalodontan element. Arched, anguliscaphate, with a prominent cusp at the apex of the element. The anterior process is longer and taller than the posterolateral and has a more or less straight upper edge. The postero-lateral process forms an angle of $170^{\circ}-175^{\circ}$ to the anterior process, and is steeply inclined distally. This element has a widely flared base which is roughly oval in outline, the basal edge on several specimens bears small irregular nodes. The basal cavity commonly contains basal material.

Astrognathodan element. Cruciform, stelliplanate element comprising a slightly arched blade and more

\section{Plate 1}

Figs 1-11. Apsidognathus tuberculatus arcticus n. ssp.

1, upper view of platform element, $\times 40$; MGUH 17.640 from GGU 216773.

2 , upper view of lenticular element, $\times 40 ;$ MGUH 17.641 from GGU 275048.

3 , oblique upper view of ambalodiform element, $\times 40$; MGUH 17.642 from GGU 229035.

4 , outer-lateral view of compressed element, $\times 40$; MGUH 17.643 from GGU 229035.

5 , posterior view of astrognathiform element, $\times 60$; MGUH 17.644 from GGU 275048.

6 , upper view of lyriform element, $\times 40$; MGUH 17.645 from GGU 216773.

7, upper view of lyriform element $\times 40$; MGUH 17.646 from GGU 229035.

8,9 , upper and lower views of lyriform element, $\times 40$; MGUH 17.647 from GGU 229035 (holotype).
10 , upper view of lyriform element, $\times 40 ;$ MGUH 17.648 from GGU 229035.

11, upper view of lyriform element, $\times 40$; MGUH 17.649 from GGU 229035.

Figs 12-16. Apsidognathus tuberculatus tuberculatus Walliser. All specimens from GGU 82687.

12, upper view of platform element, $\times 40$; MGUH 17.650.

13 , inner-lateral view of ambalodiform element, $\times 40$; MGUH 17.651 .

14 , posterior view of astrognathiform element, $\times 40$; MGUH 17.652 .

15 , inner-lateral view of coniform element, $\times 60$; MGUH 17.653.

16, upper view of lyriform element, $\times 40$; MGUH 17.654. 


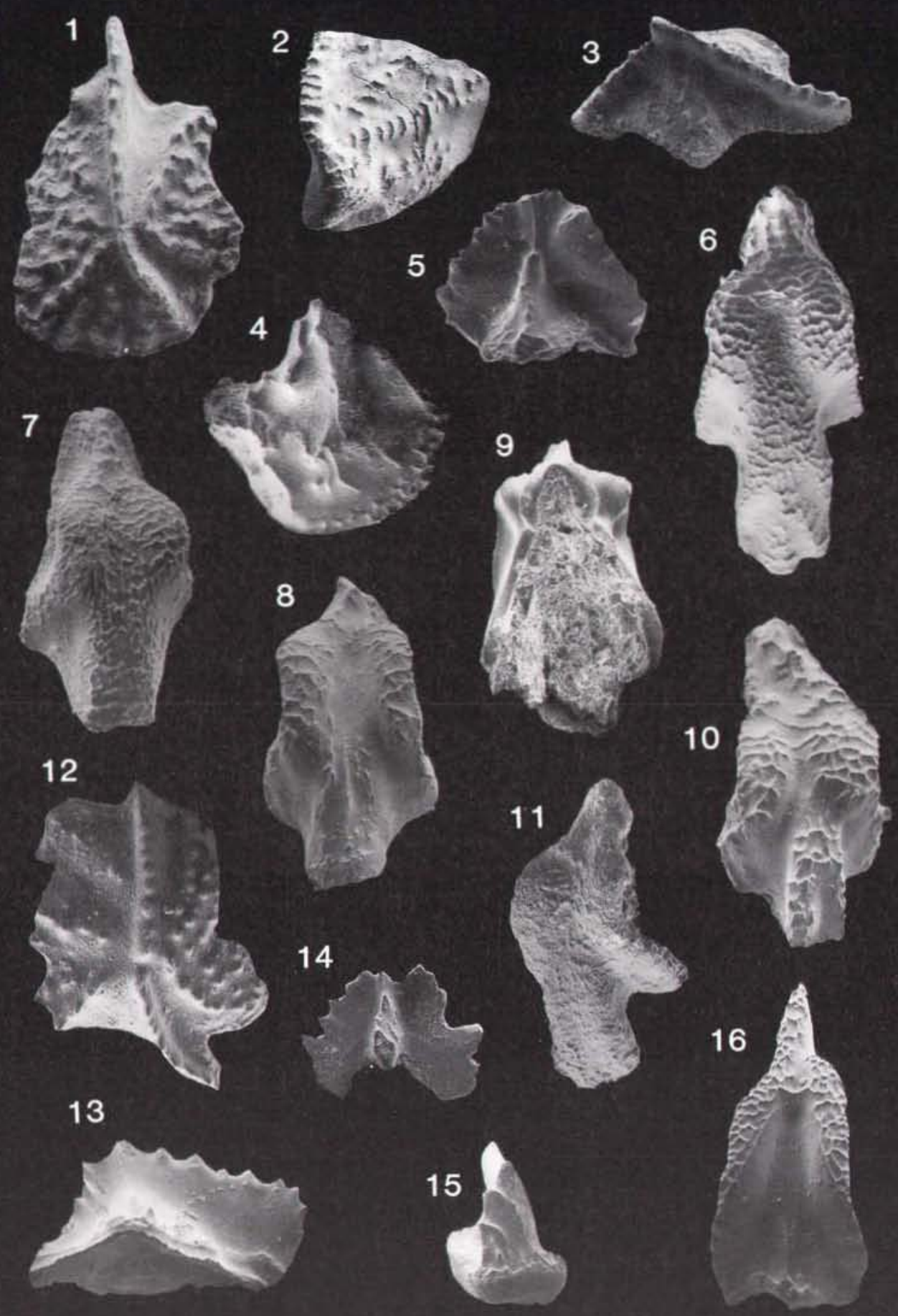


strongly arched lateral processes; all the processes are denticulate. The anterior process is approximately twice as long as the posterior; the upper edge of the posterior process is steeply inclined downwards to the posterior. Both anterior and posterior processes bear up to five completely fused nodose denticles. The lateral processes are of similar length, normal to the blade and juxtaposed. The basal cavity is deeply excavated and slightly enlarged beneath the junction of the processes. The cavity extends as a narrow groove along the anterior and posterior processes, but not under the lateral processes.

Compressed element. Laterally compressed with a much deeper outer than inner face. Rounded triangular in lateral view the anterior and posterior edges are sharp and irregular. The posterior edge is concave and extended, basally to form a rudimentary posterior process; the basal margin is broadly convex downwards. The outer face is almost vertical and ornamented by longitudinal and oblique low rugae. Centrally two subparallel main rugae extend downwards from the apex; the anterior of the two extends to the basal margin. The posterior ruga terminates slightly below midheight where a series of short radiating rugae extend along the posterior process. Below the midheight short inclined rugae are situated along the anterior edge of the outer face, and are separated from the anterior longitudinal ruga by an unornamented gap. Inter-rugae areas are commonly smooth, but rarely bear discrete slender nodes. The inner face is again almost vertical with a narrow ledge of thickening at approximately one-third the height of the face. Beneath the thickening the face is inwardly inclined. The basal cavity is narrow and deeply excavated, with commonly a thin lining of basal material.

Coniform element. Tall slender tertiopedate element with a conspicuous ledge-like lower margin. The cusp is tall, approximately twice as high as broad and triangular in cross section. Its edges are extended to form short postero-lateral processes, its posterior face is shallowly concave and bears a central longitudinal costa. The inner postero-lateral process is longer than the outer and bears three to four nodose denticles, which are fused almost to their tips; the outer process is little more than a thickened flange. In posterior view the upper edges of the lateral processes are inclined steeply downwards. The base of the cusp is expanded laterally to form a heart-shaped platform, narrow interiorly and broad posteriorly with a concave indentation on the inner side just posterior of the inner-lateral process. The platform is ornamented by low discrete to coalescing nodes. Below the upper surface of the platform the lateral edges are steep with a deep, centrally situated, $v$-shaped groove which runs around the element. The entire lower surface is excavated and commonly has a thin layer of basal material within it.

Remarks. The majority of specimens of the platform element develop rows of nodes (as in Walliser, 1964, pl. 12, fig. 21) which differ from those of the holotype of $A$. walmsleyi Aldridge (1974, fig. 1A) by being well spaced; the inner and outer platforms are subequally developed in the Greenland specimens, and deep vshaped depressions are developed between the processes.

The ambalodontan element compares closely with that previously described as A. galerus Walliser (1964), and specimens referred to that taxon by Aldridge (1974, p. 299) were regarded by him to be part of the A. walmsleyi apparatus. The Greenland specimens differ from those from Norway in possessing a more or less straight upper edge to the anterior process, thus approaching the morphology of Walliser's specimen (1964, pl. 2, fig. 6).

The lyriform element from the Greenland collection has a slightly more restricted basal cavity than the specimens figured by Walliser as P. lyra and the specimens of P.? lyra Walliser (Aldridge, 1972, p. 210, pl. 3, fig. 2). The prominence of the postero-central ridge varies from

\section{Plate 2}

Figs 1-4. Apsidognathus tuberculatus tuberculatus Walliser. All specimens from GGU $82687, \times 40$.

1, upper view of lyriform element; MGUH 17.655.

2, lower view of lyriform element; MGUH 17.656.

3 , outer-lateral view of compressed element; MGUH 17.657.

4 , inner-lateral view of compressed element; MGUH 17.658.

Figs 5-13. Apsidognathus n. sp.

All specimens from GGU 275048.
5 , upper view of platform element, $\times 20$; MGUH 17.659.

6 , oblique upper view of ambalodiform clement, $\times 40 ;$ MGUH 17.660 .

7. upper view of lyriform element, $\times 20$; MGUH 17.661.

8 , upper view of astrognathiform element, $\times 40$; MGUH 17.662 .

9. outer-lateral view of coniform element, $\times 40 ; \mathrm{MGUH}$ 17.663.

10,11 , upper and lower views of lenticular element, $\times 40$; MGUH 17.664.

12, 13, outer-lateral and inner-lateral views of compressed element. Fig. 12, × 25, fig. 13, × 40; MGUH 17.665. 

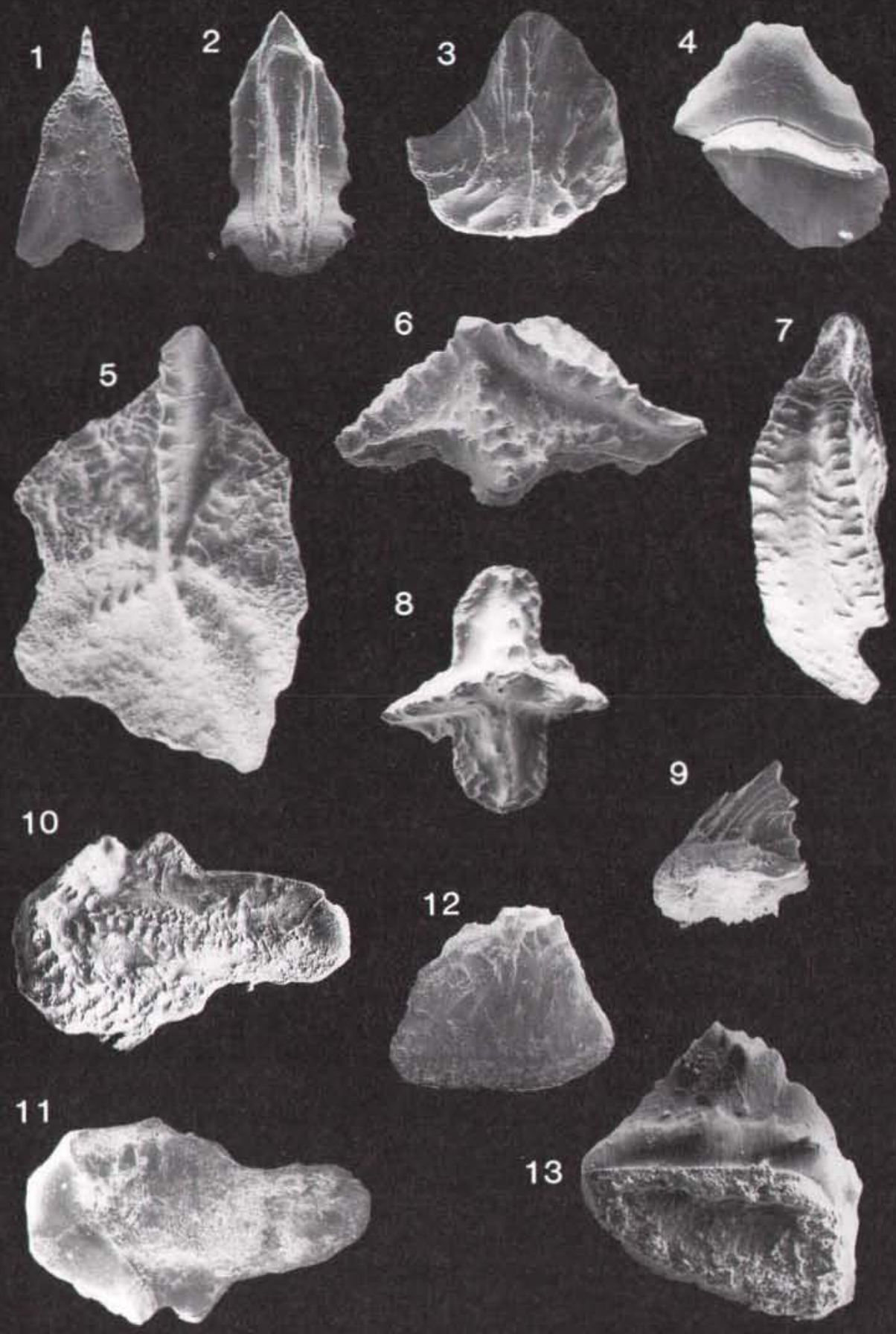
absent to barely prominent in the Greenland collections, the former being the most abundant. A range in the degree of prominence in this ridge is also shown by specimens from Gullet 4 (compare specimens, Aldridge 1972, pl. 3, fig. 2, with Aldridge 1975, pl. 1, fig. 2). The significance of this variation as a taxonomic criterion is unknown, and it does not appear to be ontogenetic as specimens of similar size occur with the ridge present or absent. The lyriform element of $A$. walmsleyi Aldridge (1975, figs 1C, 1D) has a strongly developed median posterior ridge and lobate antero-marginal ridges.

The astrognathodan elements of A. tuberculatus tuberculatus, $A$. tuberculatus arcticus and $A$. walmsleyi are similar, differing only in the relative lengths of the lateral, anterior and posterior processes; those of the former are more or less equal in length. That of $A$. walmsleyi has shorter, poorly denticulate anterior and posterior processes (Aldridge \& Mohamed, 1982).

Occurrence. Found abundantly in GGU sample 82687 of $P$. celloni Biozone age from Hall Land, less abundantly in the uppermost $P$. celloni Biozone of Peary Land.

Apsidognathus tuberculatus arcticus n. ssp. Plate 1, figs 1-11

Name derivation. From its apparent geographical restriction to Arctic Greenland.

Holotype. Specimen MGUH 17.646, a lyriform element from GGU 229035, plate 1, figs 8, 9.

Diagnosis. Characterised by the lyriform element which is robust, strongly arched and bears prominent marginal ridges and medial-posterior process.

Description. Platform element. Indistinguishable from that of A. tuberculatus tuberculatus (Walliser).

Lenticular element. Scaphate, platform well developed inner-laterally, narrow or absent outer-laterally. In upper view the platform is heart-shaped to spatulate in outline, narrowing inner-laterally. A low curved carina forms the outer-lateral margin; anteriorly this has steeply inclined lateral faces and a weakly serrate to irregular upper edge. Posteriorly the carina broadens and its midlength is inwardly curved, forming an angle of $140^{\circ}-170^{\circ}$ between the anterior and posterior processes. The posterior process is broadly rounded, lobate in large specimens and bears an ornament of low sinuous rugae which may coalesce to form a reticulum.
Outwardly the posterior process may be flared slightly to form a narrow outer-lateral process. In small specimens the posterior process does not extend to the steeply inclined posterior edge of the platform. On the inner side the narrow platform extends up to twice the longitudinal length. Centrally a broad, rounded ridge extends at $90^{\circ}$ from the point of maximum curvature of the carina. The ridge has the same ornament as the posterior process. Its anterior and posterior faces are shallowly inclined and weakly ornamented to smooth. The posterior edge of the inner-lateral platform is upturned slightly and bears a narrow, outwardly tapering zone of ornament. The entire lower surface of the element is shallowly excavated; a deep groove beneath the carina may be differentiated. Commonly the lower surface is infilled with basal material.

Ambalodontan element. Arched, pyramidal, pastiniscaphate element with a prominent apical denticle. The anterior process maintains a constant height though inclined downwards; it bears eight to ten, low almost completely fused, nodose denticles. The postero-lateral process, forming an angle of $160^{\circ}-170^{\circ}$ with the anterior process, is shorter and more steeply downwards inclined than the anterior process. It is also only weakly denticulate; its lateral faces are steeply inclined and have a broad, outwardly convex lower margin. The inner-lateral face of this element may develop a broad, lobate, inner-lateral process. This arises centrally from the base of the apical denticle, is directed slightly antero-laterally and broadens distally. When this process is present, the lower margin of the element is indented between the processes. The inner-lateral process may bear a weak ornament of low nodes or sinuous rugae and nodes. The entire lower surface is deeply excavated.

Astrognathodan element. Cruciform, stelliplanate element with a prominent apical denticle. The anterior process is slightly longer than the posterior, and both are slightly longer than the lateral processes. Both anterior and posterior processes are straight. The former bears four to six nodose, fused denticles, and decreases in height distally. The posterior process bears one or two discrete short nodes and is steeply inclined downwards towards the posterior. Basally the posterior process flares forming a narrow platform which is ornamented by a weak reticulum of low sinuous rugae. The lateral processes are subequal in length and are orientated normal to the 'blade'. They are tall proximally and are inclined steeply downwards distally. Each bears four to six low, fused nodes. Basally the lateral processes may be arched, slightly more strongly downwards than the blade. A narrow zone of recessive basal margin surrounds the basal cavity, which is restricted to a narrow, deeply excavated groove beneath the anterior and 
posterior processes. The basal cavity tapers distally and terminates before the tips of the processes.

Lyriform element. Longitudinally arched, robust, scaphate element. More or less bilaterally symmetrical about its long axis, though rare asymmetrical forms occur (plate 1, fig. 11). Anterior free blade is short and broad with an ornament of irregular nodes or short sinuous rugae, which are usually concentrated along a rounded central ridge. The lateral faces of the free blade are steeply inclined and occasionally bear an ornament of discrete nodes. A low transverse ridge or zone of ornament separates the free blade from the main platform. The platform is elongate with a rounded anterior margin. Two strongly posteriorly arched marginal ridges extend from the anterior margin; at approximately the platform midlength they are directed steeply downwards. Commonly the inner marginal ridge is slightly shorter than the outer. Both marginal ridges are ornamented with a low reticulum of sinuous rugae, the prominent elements of which run transversely. The ornament decreases in prominence posteriorly, in several specimens ornament is absent from the posterior half of the marginal ridges. The centre of the platform is shallowly depressed, varying from smooth to developing a similar ornament to the marginal ridges. A broad, rounded to rectangular posterior process arises from the centre of the platform and is free from the platform for the greater part of its length. The posterior process has a similar ornament to the marginal ridges and free blade, the distribution of this ornament varies from covering the entire process to being restricted to the posterior tip and lateral edges of the process. In this latter case the central area of the process may be shallowly depressed, only rarely ornamented by isolated nodes or sinuous low ridges. The lateral faces of the posterior process are almost vertical and usually devoid of ornament. The entire lower surface of the element is deeply excavated, beneath the free blade the cavity narrows and becomes shallower. The basal cavity is commonly infilled with basal material which may extend beyond the lower edge of the element. The variation within this element is illustrated in plate 1 , figs $6-11$.

Compressed element. Highly laterally compressed, scaphate element, the outer face is approximately half the length of the inner face. In inner-lateral view the element is rounded triangular in outline. The anterior edge is more or less straight with a central sinuous longitudinal costa along most of its length. The posterior edge is vertical to posteriorly inclined, posterobasally extended to form a short, rudimentary posterior process. The basal margin of the element is broadly convex downwards. The inner face bears an ornament of low, sinuous rugae. A prominent ruga extends down- wards from the apex which just below the midlength furcates into a series of radiating short rugae, each terminating before the basal margin of the element. A low reticulum of rugae may be developed on inner face of the posterior process. The anterior half of the basal margin bears a narrow zone of shallow pits or low reticulum. The outer face of this element is smooth occasionally with an ornament of scattered low sinuous rugac. The basal cavity is deeply excavated and rounded triangular in outline, it is broad posteriorly and narrows anteriorly. The outer-lateral edge of the cavity is thickened slightly to form a narrow ledge. The basal cavity is commonly infilled by basal material.

Remarks. A coniform element such as those present in Apsidognathus $\mathrm{n}$. $\mathrm{sp}$. and $A$. tuberculatus tuberculatus has not been recognised. The lyriform element of $A$. walmsleyi Aldridge $(1974$, p. 301 , figs $1 C, 1 D)$ has a similar overall morphology. It displays, however, smaller marginal ridges and develops a narrow ridgelike medial-posterior process.

The lenticular platform element of $A$. tuberculatus arcticus differs from its counterpart in Apsidognathus n. $\mathrm{sp}$. in the prominence of the lateral process and difference in upper surface ornament.

Occurrence. Found in moderate abundance in GGU 216773 from Washington Land and GGU 229035 from eastern Peary Land. In GGU 275048 it occurs with Apsidognathus n. sp. Specimens occur infrequently in the $P$. celloni Biozone strata of Wulff Land.

\section{Apsidognathus n. sp.}

Plate 2, figs 5-13

p1986 Apsidognathus tuberculatus; Bischoff, p. 150, figs $17-21,23-24$.

Description. Platform element. Scaphate with long carina, two inner-lateral processes and three outer-lateral processes. The platform is slightly longer than broad, is broadly oval in upper outline, shallowly indented between the lateral processes. Anteriorly the free blade is short, high and slightly laterally expanded; it continues posteriorly across the platform as a nodose carina. At midlength the carina is low and sharply inwardly curved, an angle of approximately $120^{\circ}$ being developed between the anterior and posterior processes. The posterior process is low and lobate and broadens distally where it becomes increasingly indistinct. Occasionally the posterior bears a central row of diffuse nodes. The inner side of the platform is approximately half the width of the outer platform. From the point of maxi- 
mum curvature of the carina two lobate processes diverge antero- and postero-laterally, the anterior process at an angle of $10^{\circ}-20^{\circ}$ from the anterior carina and the posterior process by $20^{\circ}-30^{\circ}$ from the posterior carina. Both inner-lateral processes are narrow, rounded ridges which decrease in height and broaden distally. At approximately two-thirds of their length they become difficult to distinguish. Both bear an ornament of low, sinuous, transverse rugae or nodes. The process interareas have a reticulate ornament to low sinuous rugae; the most prominent rugae join with those on the processes. On the outer side three processes diverge from the point of maximum curvature of the carina. The most anterior is lower and less prominent than the others, diverging at an angle of $30^{\circ}$ from the carina, from which it is separated proximally at an angle of $80^{\circ}-90^{\circ}$ from the posterior carina. The remaining process bisects the angle developed between the antero- and postero-lateral processes. At their midlength the outer-lateral processes broaden rapidly, occasionally developing a bifurcating distal end. The processes have an ornament of closely spaced low, transverse rugae which extend into the concentrically orientated rugae of the process interareas. The lower surface is shallowly excavated and commonly contains a thin layer of basal material.

Lenticular element. Scaphate with a well developed inner platform, the outer platform is absent or reduced to a flaring of the posterior process. In upper outline the element is a flattened oval with broadly rounded lateral ends. A low, broadly rounded carina forms the outerlateral margin, anteriorly this is weakly, inwardly bowed; at its midlength this is incurved and broadens to a rounded lobate process. Anteriorly the carina bears an ornament of low longitudinal rugae, posteriorly it bears a low reticulum of rugae; the more prominent of these are orientated transversely. On the inner side the platform is approximately twice as broad as long. Centrally it is raised to form a broadly rounded indistinct process which bears an ornament of irregular low rugae and low diffuse nodes. The entire lower surface of the inner platform is shallowly excavated and commonly contains a thin layer of basal material.

Ambalodontan element. Arched, pyramidal, pastiniscaphate element with a prominent apical denticle. The anterior process decreases in height anteriorly; it bears up to eight low partially fused denticles. The posterolateral process is directed inwards to form an angle of approximately $170^{\circ}$ with the anterior process, it is commonly lower than the anterior and bears six tall, almost completely fused denticles. An inner-lateral process diverges from the centre of the apical denticle and is anteriorly directed, forming an angle of $70^{\circ}-80^{\circ}$ with the anterior process. It is broader than the other processes, possessing an ornament of high transverse ridges. The lateral faces of the element are steeply inclined and the lower margin is strongly indented between the processes on the inner side. The entire lower margin is thickened, ornamented by coalescing nodes, whose prominence varies around the element. Scattered small nodes may develop on the lateral faces. The entire surface is deeply excavated.

Astrognathodan element. Cruciform, stelliplanate element with a prominent apical denticle. The anterior process is longer than the posterior and both are slightly longer than the lateral processes. The anterior process is straight, bearing four or five nodose, fused denticles. The posterior process is straight to inwardly curved and in all specimens has no well preserved denticles. The lateral processes are juxtaposed just posterior of the midlength of the blade. They are equal in length, tall proximally and decreasing in height distally; each bears two or three nodose denticles. Basally the anterior and posterior processes flare to form a narrow platform which in upper view is rounded rectangular in outline; it is not extended to the tips of the lateral processes. The margin of the platform is raised and bears an ornament of low sinuous rugae and small coalescing nodes. A narrow zone of recessive basal margin surrounds the basal cavity thus restricting it to a narrow, deeply excavated groove beneath the anterior and posterior processes. The cavity tapers distally and terminates before the tips of the processes.

Lyriform element. Arched, scaphate element, which is more or less bilaterally symmetrical, longitudinally. Anterior free blade is short and broad with an ornament of irregular nodes to low sinuous rugae. A low transverse ridge separates the blade from the main platform. The platform is narrow and consists of two, narrow raised marginal ridges separated by a broad central depression. The platform flares posteriorly and is strongly arched; it may be slightly inwardly curved. The marginal ridges decrease in height and flare slightly at their midlength. Both bear an ornament of low transverse rugae; posterior of midlength these are reduced in length rarely extending beyond the midpoint of the marginal ridge. On larger specimens short inner and outer transverse rugae alternate along the posterior half of the marginal ridges, and larger rugae may extend across the whole platform. Posteriorly the platform margin is weakly concave and ornamented by a narrow zone of small, low discrete to coalescing nodes. The lower surface has a marginal, narrow zone of recessive basal margin, centrally the lower surface is deeply excavated, under the free blade the cavity is narrow and groove-like, but still deep.

Compressed element. Laterally compressed, scaphate 
element, rounded triangular in lateral view with a broadly rounded apex. The anterior edge is broadly convex, the posterior edge anteriorly inclined and postero-basally extended to form a short rudimentary process. The basal margin may be more or less straight to convex downwards. The inner face is approximately twice as long as the outer and bears an ornament of irregular, low, sinuous rugae. These tend to become oblique towards the edges of the face and on larger specimens may be more common here. The lower margin of the inner face is ornamented with a narrow zone of discrete and coalescing nodes which becomes more diffuse and disappears upwards. The outer face is basally thickened and bears occasional scattered nodes. Above this edge the face is steep and commonly smooth, but rarely bearing isolated, low nodes. In outer-lateral view the basal cavity has a rounded-triangular outline, tapering along the posterior process. The cavity is deeply excavated and commonly has a thin layer of basal material.

?Coniform element. A single poorly preserved, scaphate pyramidal element. Laterally compressed; innerlaterally it has a tall rounded triangular outline, posterobasally extended as a short postero-lateral process; this has a serrated upper edge. The inner face is ornamented by up to eight longitudinal costae. On the outer side a short flange-like postero-lateral process diverges from the anterior edge of the element. The lower margin of the element is thickened, broadly rounded and rarely has an ornament of scattered isolated nodes. The entire lower surface is excavated.

Remarks. All elements of Apsidognathus n. sp. differ from those of previously described species of Apsidognathus though there is some morphological similarity to A. ruginosus Mabillard \& Aldridge (1983), particularly in the platform and lyriform elements. The platform element of Apsidognathus n. sp. typically has an ornament of concentrically arranged low rugae only on the outer side of the platform, whereas the whole platform of $A$. ruginosus has this ornament. The lyriform element of both species has a similar upper outline, but that of Apsidognathus n. sp. has narrower marginal ridges and a moderately broad central depression which is generally unornamented.

The astrognathodan and ambalodontan elements of Apsidognathus $\mathrm{n}$. sp. have a thickened and ornamented basal margin, which is absent in their counterparts in $A$. ruginosus. Additionally the ambalodontan element of the former is much narrower and more strongly pyramidal and develops an inner-lateral process; that of $A$. ruginosus is flattened, almost circular in upper outline and lacks an inner-lateral process. These characters also distinguish the ambalodontan and astrognathodan elements from their counterparts in $A$. tuberculatus arcticus, $A$. tuberculatus tuberculatus and $A$. walmsleyi.

Mabillard \& Aldridge (1983) included slender conical and squat conical elements in the apparatus of $A$. ruginosus. The squat element is comparable with that named Pseudooneotodus n. sp. by Cooper (1977a, pl. 2, figs 12,13$)$. The coniform(?) element of Apsidognathus n. sp. differs from both of the conical elements of $A$. ruginosus in possessing two short postero-lateral processes and an inner face ornamented by up to eight longitudinal costae.

Until larger collections of $A$. ruginosus and Apsidognathus $\mathrm{n}$. $\mathrm{sp}$. are available, the intraspecific variation of their constituent elements cannot be assessed. Apsidognathus $\mathrm{n}$. sp. may prove to be synonymous with, or a geographical subspecies of, A. ruginosus.

Occurrence. Occurs with abundant Pterospathodus pennatus rhodesi, P. amorphognathoides and A. tuberculatus arcticus in GGU 275048 Valdemar Glückstadt Land.

\section{Genus Aspelundia Savage, 1985}

Type species, Aspelundia capensis Savage, 1985, p. 725.

Emended diagnosis. Septimembrate comprising digyrate $(\mathrm{Pa})$ and angulate $(\mathrm{Pb})$ elements with twisted processes; dolabrate, alate, tertiopedate, modified tertiopedate and bipennate elements form the ramiform complex. All elements are highly compressed.

Remarks. Savage (1985, p. 725) erected Aspelundia n. gen. to include elements of late Pterospathodus amorphognathoides Biozone age which had pronounced lateral processes, small or no basal cavity and a high degree of lateral compression. Within the apparatus of the type species, $A$. capensis, he placed a digyrate $\mathrm{Pa}$ (figs $19 \mathrm{~A}, \mathrm{~B}$ ), digyrate $\mathrm{Pb}$ (figs 19E,F), digyrate $\mathrm{M}$ (figs 19G-I), tertiopedate Sb (figs $19 \mathrm{M}, \mathrm{N}$ ) and a digyrate Sc (fig. 19L). He also figured and described an alate Sa element (figs 19Q-T) though did not include this in the diagnosis.

Based upon the large collections from the Pterospathodus celloni Biozone of North Greenland and the lower P. amorphognathoides Biozone of the McKenzie Mountains (Over \& Chatterton, 1987) it is apparent that species attributable to Aspelundia had a septimembrate apparatus, by virtue of bearing elements with strong lateral compression, variably twisted lateral processes, small basal cavity and similar white matter distribution.

The emended generic concept can be illustrated by 
comparing homologous elements in A. fluegeli (herein) and 'Aspelundia' n. sp. 1 Over \& Chatterton, 1987. The platform complex comprised a digyrate $(\mathrm{Pa})$ element (plate 3 , fig. 1 with plate 5 , figs 11,14 ) and an angulate $(\mathrm{Pb})$ element (plate 3 , fig. 2 with plate 5 , fig 1 ). The ramiform complex contained a dolabrate (M) element (plate 3, fig 3 with plate 5, fig. 13), an alate (Sa) element (plate 3 , fig. 4 with plate 5 , fig. 17), tertiopedate (Sb) elements (plate 3 , figs 5-7 with plate 5, fig. 16) and bipennate $(\mathrm{Sc})$ elements (plate 3 , figs 11,12 with plate 5 , fig. 15). A. fluegeli also possessed a modified tertiopedate (Sd) element (plate 3, figs 8-9) which has not been described for the other species.

Using the revised concept for the genus it is apparent that Savage (1985) only figured a partial reconstruction for the type species, Pa (figs 19A-L), ?Sa (figs 19Q-T) and Sb (figs 19M-P). Samples 3, 17 and 19 from the Heceta Limestone contain abundant $A$. capensis and Pandorinellina plana elements. The latter has an identical apparatus plan to that proposed for Aspelundia. The $\mathrm{Pa}$ element (figs 18B, ?D-E; non fig. $18 \mathrm{C}$ which is an Sc element) has the root of a lateral process just to the posterior of a prominent cusp, a characteristic of the $\mathrm{Pa}$ element of 'Aspelundia' ?n. sp. 2 Over \& Chatterton (1987, plate 5, fig. 19). The Pb element (Savage, 1985, figs $18 \mathrm{~F}, \mathrm{H}$ ) is large, robust, has rounded denticles and possesses a narrow ledge-like platform beneath the denticle row. This may be an element of Oulodus, a gerontic Aspelundia $\mathrm{Pb}$ element or an aberrant form. The remaining elements, M (figs $18 \mathrm{H}-\mathrm{J}$ ), Sa (figs $18 \mathrm{~V}-\mathrm{Y}$ ) and Sc (figs 180-Q) are typical of Aspelundia species. From the illustrations it is difficult to decide whether or not these elements belong to $A$. capensis sensu Savage. This species is a partial reconstruction based upon common occurrence of the elements in the Heceta Limestone and which may have had vicariously shared $\mathrm{Pb}$,
M, Sa and Sc elements with 'Aspelundia' n. sp. 2 Over \& Chatterton, 1987.

It is apparent from Pa morphology that the evolution of Aspelundia involved a reduction in the size of the basal cavity and an increase in the twisting of the processes and the number of denticles on the $\mathrm{Pa}, \mathrm{Pb}$ and $\mathrm{Sa}$ elements. Aspelundia and some species of Ozarkodina appear to be closely related, particularly with $O$. polinclinata (Nicoll \& Rexroad) sensu Oulodus Cooper (1977a, p. 1058) and $O$. pirata McCracken \& Barnes (O. aff. O. polinclinata sensu Aldridge, 1979) which have almost indistinguishable $\mathrm{M}$ and $\mathrm{Sc}$ elements from Aspelundia species.

Aspelundia expansa n. sp.

Plate 3, figs 13-20

Name derivation. 'expansa' refers to the broadly expanded basal cavity present in all elements of the apparatus of this species.

Holotype. Specimen MGUH 17.687, plate 3, fig. 13; a Pb element from sample GGU 216837, Cape Schuchert Formation, Kap Schuchert, Washington Land. western North Greenland.

Diagnosis. Aspelundia species in which the elements have compressed robust denticles and a broad, shallowly excavated basal cavity. Modified angulate $\mathrm{Pa}$ element.

Description. Pa element. Modified angulate element consisting of a prominent cusp and anterior and outwardly twisted and occasionally bowed posterior process. The cusp is laterally compressed, posteriorly in-

\section{Plate 3}

Figs 1-9. Aspelundia fluegeli (Walliser).

All specimens from GGU 216852, $\times 60$.

1, inner-lateral view of $\mathrm{Pb}$ element; MGUH 17.675.

2, inner-lateral view of $\mathrm{Pa}$ element; MGUH 17.676.

3 , inner-lateral view of M element; MGUH 17.677.

4 , lower view of Sa element; MGUH 17.678.

5 , posterior view of $\mathrm{Sb}_{2}$ element; MGUH 17.679.

6 , posterior view of $\mathrm{Sb}_{1}$ element; MGUH 17.680.

7 , posterior view of $\mathrm{Sb}_{1}$ element; MGUH 17.681.

8, posterior view of Sd element; MGUH 17.682.

9. posterior view of Sd element; MGUH 17.683.

Fig. 10. Aspelundia n. sp. 1 (Over \& Chatterton). MGUH 17.684, from GGU 216852, × 60 .

10 , lower view of $\mathrm{Pa}$ element.
Figs 11-12. Aspelundia fluegeli (Walliser).

11, inner-lateral view of Sc element; MGUH 17.685.

12, inner-lateral view of Sc element; MGUH 17.686.

Figs 13-20. Aspelundia expansa n. sp.

All specimens from GGU $216837, \times 60$.

13, oblique lower view of $\mathrm{Pb}$ element; MGUH 17.687 (holotype).

14, inner-lateral view of $\mathrm{Pa}$ element; MGUH 17.688.

15, inner-lateral view of M element; MGUH 17.689.

16, inner-lateral view of Sc element; MGUH 17.690.

17, lower view of Sa element; MGUH 17.691.

18, posterior view of $\mathrm{Sb}_{2}$ element; MGUH 17.692.

19, posterior view of $\mathrm{Sb}_{1}$ element; MGUH 17.693.

20, posterior view of $\mathrm{Sb}_{1}$ element; MGUH 17.694. 

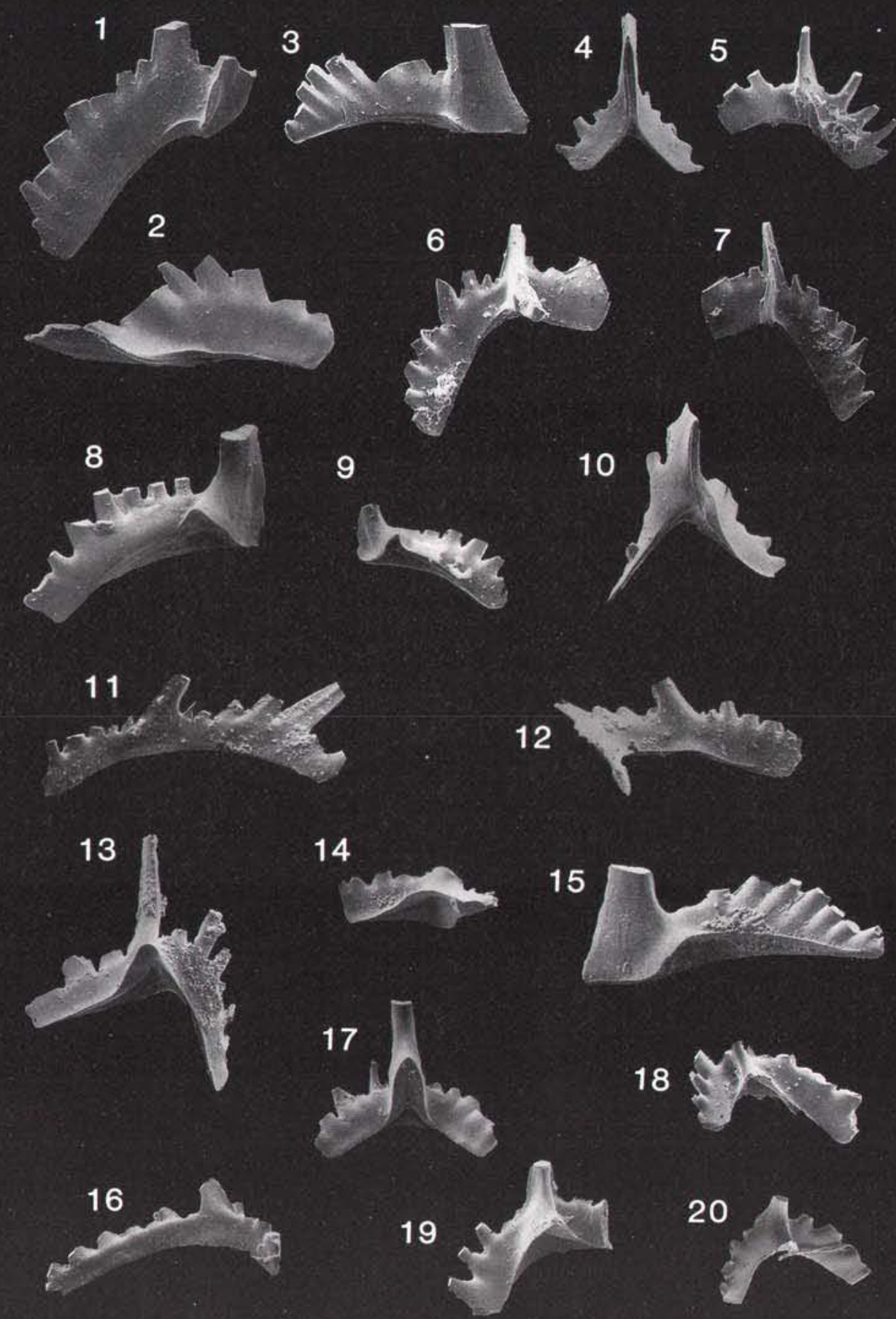
clined and lenticular in cross section. The anterior process lies in the plane of the cusp, is shorter than the posterior process and bears up to three laterally compressed, partially fused, posteriorly inclined denticles. The posterior process bears up to four compressed, posteriorly inclined denticles, separated by v-shaped spaces. The basal cavity is broadly excavated beneath the cusp and oval in lower outline, extending as a broad, tapering groove to the tips of the processes. White matter forms blocks completely filling each denticle and the cusp.

$\mathrm{Pb}$ element. Digyrate element consisting of a small cusp and two denticulated lateral processes; the inner process is the shorter and is twisted anteriorly. Occasionally a short adenticulate inwardly directed projection is present beneath the first proximal denticle of the inner-lateral process. The cusp is small, rarely broader than the denticles, laterally compressed and inclined slightly towards the inner-lateral process. It has a flattened lenticular cross section. The outer-lateral process is straight and downturned, forming an angle of $100^{\circ}$ with the lateral edge of the cusp. It bears four to ten laterally compressed, partially fused denticles, these are inclined towards the cusp. The inner-lateral process bearing up to ten compressed denticles, of which the two most proximal are smaller than the others. The basal cavity is broadly expanded beneath the cusp, its lower posterior edge is upturned and asymetrically inclined towards the inner-lateral process. In lower view it is rounded in outline and tapers rapidly to a narrow groove which extends to the tips of the processes.

$M$ element. Dolabrate, with large laterally compressed, posteriorly inclined cusp and a long inwardly bowed posterior process. The cusp is separated slightly from the posterior process and is inwardly twisted; its anterior edge is sharp, its posterior edge rounded. The posterior process is compressed, directed outwardly and bowed inwardly. It bears six to eight compressed, posteriorly inclined denticles, which are separated from the cusp. The denticles increase in size towards the centre of the process. The basal cavity is shallowly excavated beneath the cusp, its inner, lower edge is upturned and flares laterally beneath the posterior edge of the cusp and process.

Sa element. Alate, the cusp is oval in outline and is highly inclined to the posterior. Compressed lateral processes of equal length arise from the antero-lateral edges of the cusp; these are bowed posteriorly and downwardly directed, in posterior view forming an angle of $160^{\circ}$ between their lower edges. Each bears up to five compressed partially fused, tall denticles. The basal cavity is laterally expanded, extending as a broad groove beneath the cusp and as a narrower groove along the processes.

$S b_{\text {I }}$ element. Tertiopedate element with a short posterior projection at the base of the cusp. The cusp is laterally compressed with a broadly rounded anterior and sharp costate posterior edge; it is rounded triangular in midheight cross section and inclined towards the inner-lateral process. The lateral processes diverge, antero-laterally and arch downwards, the outer is longer and more steeply inclined than the inner. An asymmetrical arch of some $110^{\circ}$ is produced between the lower edges of the processes, both bearing up to five, compressed, discrete, but closely packed denticles which are inclined away from the cusp. Denticles on the outer-lateral process are more closely packed than those on the inner-lateral process. The posterior edge of the basal cavity is posteriorly expanded and upturned beneath the cusp, where it is laterally restricted; extending as a rapidly tapering groove to the tips of the processes. In lower view the cavity beneath the cusp is triangular.

$\mathrm{Sb}_{2}$ element. Similar to but much rarer than the $\mathrm{Sb}_{1}$ element. Differing only in the morphology of the cusp and basal cavity outline. Both the anterior and posterior edges of the cusp are rounded, the posterior edge lacking the costa of the $\mathrm{Sb}_{1}$ element. Accordingly the basal cavity margin is broadly rounded, oval in outline beneath the cusp. The basal cavity extends as a tapering groove to the tips of the lateral processes.

Sc element. Bipennate element consisting of a short anterior and a long posterior process. The cusp is laterally compressed, posteriorly inclined, and rounded lenticular in cross section. The anterior process is directed downwards, forming an angle of $110^{\circ}$ to the anterior edge of the cusp, and slightly inwardly bowed along its length. It bears up to six compressed, closely packed denticles. The straight posterior process is also directed slightly downwards and bears six to eight compressed, posteriorly inclined denticles. The basal cavity is expanded beneath the cusp extending as a narrow groove to the tips of the element.

Remarks. The apparatus structure is similar to $A$. fluegeli, although no Sd element has been found in the Greenland collections.

Occurrence. Common in the middle Llandovery of Washington Land, found infrequently in Wulff Land and Kronprins Christian Land. 
Aspelundia fluegeli (Walliser, 1964)

Plate 3, figs $1-9,11,12$

v*1964 Lonchodina fluegeli, p. 44, pl. 6, fig. 4; pl. 32, figs $22-24$.

v1964 Neoprioniodus planus Walliser, p. 51, pl. 4, fig. 10 ; pl. 6 , fig. 3 ; pl. 29 , figs $12,13,15$.

v1964 ?Roundya trichonodelloides Walliser, p. 72, pl. 6, fig. 2 ; pl. 31, figs 22-25.

1966 Lonchodina fluegeli Spasov \& Filipović, p. 42, pl. 2 , fig. 10.

1968 Roundya? sp. D Igo \& Koike, p. 18, pl. 3, fig. 29.

p1968 Trichonodella symmetrica; Igo \& Koike; p. 19, pl. 3 , fig. 10 ; non fig. 11 .

1968 Plectospathodus extensus; Igo \& Koike, p. 15, pl. 3, fig. 12 .

?1968 Roundya sp. B Igo \& Koike, p. 17, pl. 1, figs 1, 2.

?1968 Neoprioniodus planus; Igo \& Koike, p. 12, pl. 1, figs 15,18 ; pl. 3 , fig. 21 .

v1972 Hibbardella? trichonodelloides; Aldridge, p. 182, pl. 6 , figs 17,18 .

v1972 Lonchodina detorta; Aldridge, p. 190, pl. 8, fig. 6 .

v1972 Lonchodina fluegeli; Aldridge, p. 190 , pl. 8, fig. 7.

v1972 Neoprioniodus planus; Aldridge, p. 195, pl. 5, fig. 23 .

p1975 Ozarkodina plana; Sweet \& Schönlaub, p. 52, pl. 1, figs 1, 3, 4, ?5, 6 only; non fig. 2 .

v1979 Oulodus? fluegeli; Aldridge, p. 14, pl. 2, figs $6-11$

1980 Gen. and sp. indet. A Helfrich, p. 568, pl. 1, figs $7-12$.

1982 Oulodus? fluegeli; Aldridge \& Mohamed, pl. 11, figs 26,27 .

1983 Oulodus? cf. O.? fluegeli; Uyeno \& Barnes, p. 19 , pl. 1 , figs $1-6$.

v1983 Oulodus? fluegeli; Mabillard \& Aldridge, pl. 2, figs 15,16 .

v1985 Oulodus? fluegeli; Aldridge, p. 80, pl. 3.1, figs 18-23.

1985 Oulodus? fluegeli; Norford \& Orchard, p. 11, pl. 1, figs 2, 9, 10, 12-14, 16-18, 20, 21.

1986 Oulodus planus planus; Bischoff, p. 80 , pl. 19, figs $39-41$; pl. 20 , figs $1-7,17-44$; pl. 21 , figs $1-12$.

1987 Oulodus? fluegeli; Over \& Chatterton, p. 23, pl. 1 , figs $30-38$.

Holotype. Lonchodina fluegeli Walliser, 1964, p. 44, pl. 6 , fig. 4 ; pl. 32, fig. 24. From the Llandovery of Cellon in the Carnic Alps (Austria).

Emended diagnosis. A species of Aspelundia in which all the elements are characterised by a narrowly expanded basal cavity and compressed denticles; the $\mathrm{Pa}$, $\mathrm{Pb}, \mathrm{M}$ and $\mathrm{Sc}$ elements have variably twisted and flexed processes.

Description. Pa element. Modified angulate, pectiniform element, with two laterally compressed denticulated processes. The cusp is posteriorly inclined, laterally compressed and lenticular in cross section. The anterior process is generally shorter than the posterior and bears four or five discrete, though closely packed, denticles. The inclination of these varies from vertical to slightly posteriorly inclined. The posterior process has four or five denticles, its upper edge is twisted outwards, almost becoming horizontal in some specimens. Distally the posterior process may be slightly inwardly bowed. The basal cavity is only slightly flared beneath the cusp and extends as narrow grooves to the tips of the processes. In lateral view white matter, in the form of regular separate blocks, completely fills and is restricted to each denticle and the cusp. The base of these white matter blocks never extends below the midheight of the processes.

$\mathrm{Pb}$ element. Digyrate element with two lateral processes and occasionally a short posterior or postero-lateral process. The cusp is tall and slender, rarely broader than the denticles; it is laterally compressed and has a lenticular midheight cross section. The outer-lateral process is straight and downturned forming an angle of approximately $120^{\circ}$ with the outer lateral edge of the cusp. It bears up to ten compressed partially fused denticles, which are inclined slightly towards the cusp. The inner-lateral process is usually the shorter of the two and is downturned and sharply anteriorly twisted. Maximum twisting occurs beyond the first proximal denticle. This process bears up to five closely packed compressed denticles which are inclined away from the cusp. Beneath the cusp or under the first proximal denticle on the outer-lateral process, a short posterior or posterolateral denticulate process is occasionally developed; this is broken in all specimens. The basal cavity is shallowly excavated, broadest beneath the cusp and tapering rapidly to a groove which extends to the tips of the processes. White matter is distributed as in the Pa element.

$M$ element. Dolabrate with a tall, laterally compressed, posteriorly inclined cusp and posterior process. The anterior edge of the cusp is sharp, the posterior variously rounded to sharp. The cusp is offset from the plane of the posterior process, rotated slightly inwards. The posterior process is compressed and flexed, and bears six to eight closely packed denticles. These are commonly fused to midheight and increase in height towards the centre of the process. The lower edge of the element steps up to beneath the posterior edge of the cusp and posterior process. The lower margin is slightly flared inwards. The basal cavity is shallowly excavated and most widely flared beneath the posterior edge of the cusp; it extends as a narrow groove to the tip of the posterior process. White matter distribution is comparable with that in the Pa element.

Sa element. Symmetrically arched, alate element, 
comprising a long, compressed posteriorly inclined cusp, two long anterior-lateral processes and a much reduced posterior process. The cusp is strongly compressed, flattened lenticular in midheight cross section. Compressed, antero-lateral processes, equal in length, diverge from the anterior edge of the cusp; these are arched antero-laterally forming an angle of $90^{\circ}$. Each process bears up to eight small, compressed denticles, which are only partially fused. The basal cavity is deepest beneath the cusp, extending posteriorly as a long, narrow groove; beneath the lateral processes the cavity is narrower, the cavity extends to the tips of all the processes.

$\mathrm{Sb}$ elements. $\mathrm{Sb}_{1}$-tertiopedate element with a short posterior process. The cusp is inclined inwards, laterally compressed and lenticular in midheight cross section; it is extended posteriorly at its base as a prominent longitudinal costa, which may develop into a short posterior process, bearing two or three compressed denticles (plate 3, fig. 6). Alternatively this process may be absent $\left(\mathrm{Sb}_{2}\right)$ (plate 3, fig. 5) in which case the posterior edge of the basal cavity is arched upwards, laterally restricted and inclined towards the inner process. Two compressed antero-lateral processes diverge from the anterior edge of the cusp The inner of the two is shorter and bears up to four broad partially fused denticles, the outer process bears up to seven denticles. The basal cavity is shallowly excavated beneath the cusp and extends as a broad groove beneath the processes. White matter distribution is as described for the $\mathrm{P}$ elements.

$S c$ element. Bipennate with a short, inwardly bowed anterior process and longer posterior process. The cusp and denticles are laterally compressed and posteriorly inclined, the cusp is lenticular in cross section. The denticles are closely packed, usually fused on the anterior process; there are up to six denticles on the anterior process and six to eight on the posterior process. The distal tip of the posterior process is commonly twisted inwards, occasionally recurved to be directed anteriorly (plate 3, fig. 12). The basal cavity is wide beneath the cusp, extending as a narrow groove to the tips of the processes. A secondary widening of the cavity may occur beneath the distal flexure of the posterior process.

?Sd element. Modified tertiopedate element, consisting of a laterally compressed, posteriorly expanded cusp and long, downwardly arched outer-lateral process. The lateral edges of the cusp are sharp. The outer process diverges from the base of the cusp, forming an angle of $100^{\circ}-120^{\circ}$ with the edge of the cusp; it bears up to eight compressed denticles which are separated from the cusp by a narrow gap. The posterior edge of the basal cavity is posteriorly extended and broadly arched. The basal cavity is broad beneath the cusp, shallowly excavated, extending beneath the outer process as a narrow groove. White matter distribution is similar to that of the outer elements.

Remarks. A. fluegeli differs from the stratigraphically older $A$. expansa $\mathrm{n}$. sp. in the morphology of the $\mathrm{Pb}$ and $\mathrm{Sb}$ elements and the narrower basal cavity of all elements. The Sd element described herein is rare, occurring only in large collections. This may be a separate member of the apparatus or an aberrant M/Sb element. Two Sb morphotypes are associated with $A$. fluegeli elements, differing on the presence or absence of a posterior process.

Apparatus bauplans with multiple Sb elements are not uncommon. From the Upper Silurian, Kuwano (1982) has recorded two Sb elements in the apparatus of Ozarkodina excavata excavata (Branson \& Mehl) and Sparling (1981, p. 304) has suggested that Oulodus elegans (Walliser) may have had a seventh element assignable to a second $\mathrm{Sb}$ position. The Devonian Oulodus angulatus (Hinde), described by Nicoll (1977) from a natural assemblage in the fish gut of a palaeoniscoid fish, contains two Sb elements which compare closely in postero-basal cusp morphology with the two Sb morphotypes of Aspelundia fluegeli. By the Carboniferous apparatus structures with two $\mathrm{Sb}$ elements appear to have become extremely common (Norby, 1976). Over \& Chatterton (1987, pl. 5, figs 22-23) figure two similar Sb morphotypes in their reconstruction of Oulodus? n. sp. 2 a species probably synonomous with $A$. capensis.

As first revisors Sweet \& Schönlaub (1975) included within their concept of Ozarkodina plana a mixture of elements attributable to A. fluegeli and Ozarkodina excavata (Aldridge, 1979, p. 15). Subsequently, Aldridge (1979) erected a new species Oulodus? fluegeli placing in synonomy the $\mathrm{Pb}, \mathrm{Sb}$ and $\mathrm{M}$ elements of Ozarkodina plana. The planiform M element formerly referred to Neoprioniodus planus of Walliser (1964) is extremely difficult to distinguish from the $\mathrm{M}$ element of Ozarkodina polinclinata (Nicoll \& Rexroad), reconstructed by Cooper (1977, p. 1058). Consequently, the specific name planus may be considered a nomen dubium and the action of Aldridge (1979) is supported, this species bearing the name $A$. fluegeli rather than $A$. plana.

Occurrence. Extremely abundant in middle-upper Llandovery samples at Kap Schuchert (fig. 21). Here $A$ fluegeli is associated with abundant Dapsilodus obliquicostatus almost to the exclusion of other species. In Peary Land $A$. fluegeli is restricted to the $P$. celloni Biozone. The $\mathrm{M}$ and $\mathrm{Sc}$ elements of this species are indistinguishable from those of Ozarkodina pirata and, 
when the two species occur together these elements may have been misindentified.

\author{
Aspelundia n. sp. 1 (Over \& Chatterton, 1987) \\ Plate 3, fig. 10.
}

1969 Diadelognathus spp. Nicoll \& Rexroad, p. 29-31, pl. 6, figs 1-10.

1983 Oulodus? fluegeli subsp. A. Uyeno in Uyeno \& Barnes, p. 18-19, pl. 7, figs 11-20, ?22.

1983 Oulodus? fluegeli; Mabillard \& Aldridge, pl. 2, figs $15-16$.

1987 Oulodus? n. sp. 1 Over \& Chatterton, p. 23, pl. 5, figs $11-17$.

Diagnosis. Refer to Over \& Chatterton (1987, p. 23).

Remarks. This species occurs rarely in late $P$. celloni Biozone samples from Washington Land, In these collections it can be distinguished from $A$. fluegeli only by its $\mathrm{Pa}$ element which bears a large compressed cusp, an undenticulated process over the basal cavity and a narrow basal cavity. This species differs from Oulodus planus borenorensis Bischoff $(1986$, p. 84$)$ in which the $\mathrm{Pa}$ element has an additional denticulated process above the basal cavity.

Aspelundia? n. sp. A

Plate 4, figs 1-5

Description. Only a single specimen of each element occurs in the Greenland collection.

Pa element. Carminate, laterally compressed element with large denticle and a small cusp situated just posterior to the midlength. The cusp is posteriorly inclined, laterally compressed and lenticular in cross section. The posterior process is shorter and shallower than the anterior and bears three discrete, laterally compressed triangular denticles; the most proximal of these is fused to the cusp below its midheight. The most distal denticle on the posterior process is much smaller and separated from the central denticle by a 'u-shaped' rather than ' $v$-shaped' gap. The anterior process bears four triangular, pointed denticles which are fused to midheight. These are smaller than those on the posterior process. The lower edge of the element is higher beneath the cusp and posterior process than the anterior process. The basal cavity is expanded slightly beneath the cusp, extending as a rapidly tapering narrow groove, to the tips of the processes.

$\mathrm{Pb}$ element. Digyrate, comprising compressed lateral processes and an antero-posteriorly compressed cusp. The outer-lateral process is broken, though directed slightly towards the anterior and bears the remains of two laterally compressed denticles. The inner-lateral process is complete and bears five tall, laterally compressed, partially fused denticles. The basal cavity flares posteriorly beneath the cusp, and is asymmetrically inclined towards the outer-lateral process. The cavity extends as a rapidly narrowing groove to the tips of the lateral processes.

$M$ element. A dolabrate element, consisting of a laterally compressed cusp and a short denticulate posterior process, occurs with the $\mathrm{Pa}$ element. The cusp is inclined posteriorly with a straight posterior edge and flexed anterior edge. The posterior process projects at an angle of $90^{\circ}$ from the base of the cusp and bears four posteriorly inclined, laterally compressed, completely fused denticle stubs; the most proximal of which is much smaller than the others from which it is separated by a gap. The basal cavity is expanded slightly beneath the posterior edge of the cusp, extending posteriorly as a rapidly tapering groove to the tip of the posterior process.

$? S b_{2}$ element. Tertiopedate, in posterior view the cusp is broad and antero-posteriorly compressed; the outerlateral process bears seven compressed denticles. The most distal of these is small, peg-like and discrete from the other denticles. The inner-lateral process is broken and bears two compressed denticles. An angle of $160^{\circ}$ is developed between the lower ledges of the lateral processes. The posterior edge of the basal cavity is expanded slightly, upturned and offset towards the inner-lateral process, extending laterally, and terminates just before the tip of the inner-lateral processes.

Sc element. Bipennate with a short, inwardly curved, downturned, short anterior process; the posterior process is long and slightly downturned, it bears six compressed, discrete denticles which are separated by ' $\mathrm{v}$ shaped' spaces. The anterior process bears a single denticle which is fused to the antero-lateral edge of the cusp. The basal cavity is slightly expanded beneath the cusp, oval in lower outline and extends as a narrow groove to the tip of the anterior process, but terminates posteriorly before the tip of the posterior process.

Remarks. These elements are morphologically similar to those of Boerglumella and appear to fit the same apparatus plan. Until an $\mathrm{Sb}_{1}$ element is recognised this species can only be questionably assigned to this genus, but it may represent the oldest known representative of the Aspelundia lineage.

Occurrence. Found in GGU sample 256335, from the upper Ordovician part of the Turesø Formation of eastern Peary Land. 
Aspelundia? n. sp. B

Plate 4, figs 6-13

Description. Pa element. Digyrate with small laterally compressed cusp, short anterior process and longer posterior process. The anterior process consists of a single, inner-laterally twisted, large compressed denticle, fused to the anterior edge of the cusp; the posterior process is inwardly bowed and bears four denticles which are posteriorly and inwardly inclined and separated from the cusp by a narrow gap. The lower surface is expanded to form a narrow platform which is broader posteriorly than anteriorly. The basal cavity is shallowly excavated and a deep basal pit is located beneath the cusp. In lateral view the denticles are filled with angular blocks of white matter, the bases of these blocks define a sharp linear trace at the midheight of both processes.

$\mathrm{Pb}$ element. Angulate and slightly inwardly bowed, the cusp and denticles are laterally compressed, posteriorly inclined and lenticular in cross section. The anterior process is slightly longer and deeper than the posterior and bears four large, partially fused denticles; the most distal of these is much smaller than the rest. The posterior process bears only three denticles, which are fused to midheight. The basal cavity is narrowly flared beneath the cusp, extending to the tips of the processes as a narrow, shallowly excavated groove. In lateral view white matter fills each denticle.

$M$ element. Dolabrate with a tall, erect, laterally compressed cusp, denticulate posterior process and adentic- ulate anticusp. The posterior process extends slightly downwards from the base of the cusp, forming an angle of approximately $100^{\circ}$ with the lower edge of the anticusp. It bears six triangular, laterally compressed denticles; the four proximal to the cusp are partially fused, the two most distal are discrete. The anticusp is more or less parallel to the anterior edge of the cusp. Beneath the cusp the basal cavity is slightly, inwardly flared, extending as a narrow groove to the tip of the posterior process.

Sa element. Alate, the cusp is posteriorly curved, compressed and subrounded in midheight cross section. Two symmetrically disposed antero-lateral processes diverge at an angle of $60^{\circ}-75^{\circ}$ beneath the cusp, each bears three discrete, compressed denticles, separated by ' $u$-shaped' spaces. The posterior process extends from the lower posterior edge of the cusp and bears up to six laterally compressed, posteriorly inclined, partially fused denticles. The basal cavity extends beneath the posterior process as a broad groove, and along the lateral processes as a narrower groove. White matter distribution is similar to that described for the $\mathrm{Pb}$ element.

$S b_{I}$ element. Tertiopedate, the cusp is erect and laterally compressed, with a costa on the posterior edge; it is triangular in midheight cross section. The inner-lateral process is less steeply inclined than the outer, an angle of approximately $100^{\circ}$ being developed between the lower edges of the lateral processes. Each lateral process bears four or five compressed, discrete denticles. The posterior process, bears two or three compressed denticles. The basal cavity extends to the tips of

\section{Plate 4}

Figs 1-5. Aspelundia? n. sp. A. All specimens from GGU 256335, $\times 60$.

1, oblique lower view of $\mathrm{Pb}$ element; MGUH 17.695.

2, inner-lateral view of Pa element; MGUH 17.696.

3, inner-lateral view of M element; MGUH 17.697.

4 , posterior view of ? $\mathrm{Sb}_{2}$ element; MGUH 17.698.

5 , inner-lateral view of Sc element; MGUH 17.699.

Figs 6-13. Aspelundia? n. sp. B.

All specimens from GGU 216809, $\times 60$.

6, lateral view of Pa element; MGUH 17.700.

7, upper view of $\mathrm{Pa}$ element; MGUH 17.701.

8, inner-lateral view of Pb element; MGUH 17.702.

9, posterior view of Sa element; MGUH 17.703.

10, inner-lateral view of Sc element; MGUH 17.704.

11. posterior view of $\mathrm{Sb}_{1}$ element; MGUH 17.705 .

12, posterior view of M element; MGUH 17.706

13 , inner-lateral view of ?Sb 2 element; MGUH 17.707.
Figs 14-29. Carniodus carnulus Walliser. All specimens from GGU $216853, \times 60$.

14, lateral view of carinthiaciform element; MGUH 17.708.

15, lateral view of carinthiaciform element; MGUH 17.709.

16, lateral view of carinthiaciform element; MGUH 17.710.

17, lateral view of carinthiaciform element; MGUH 17.711.

18, lateral view of carinthiaciform element; MGUH 17.712.

19 , inner-lateral view of modified carinthiaciform element; MGUH 17.713.

20, inner-lateral view of carnuliform element; MGUH 17.714.

21 , inner-lateral view of neoprioniodan (M) element; MGUH 17.715 .

22, posterior view of latialatiform element; MGUH 17.716.

23, lateral view of latialatiform element; MGUH 17.717.

24, posterior view of carniform element; MGUH 17.718 .

25, anterior view of (?)carniciform element; MGUH 17.719.

26, posterior view of carnuliform element; MGUH 17.720.

27, posterior view of carnuliform element; MGUH 17.721.

28 , lateral view of carnuliform element; MGUH 17.722.

29 , outer-lateral view of subcarniform element; MGUH 17.723 . 


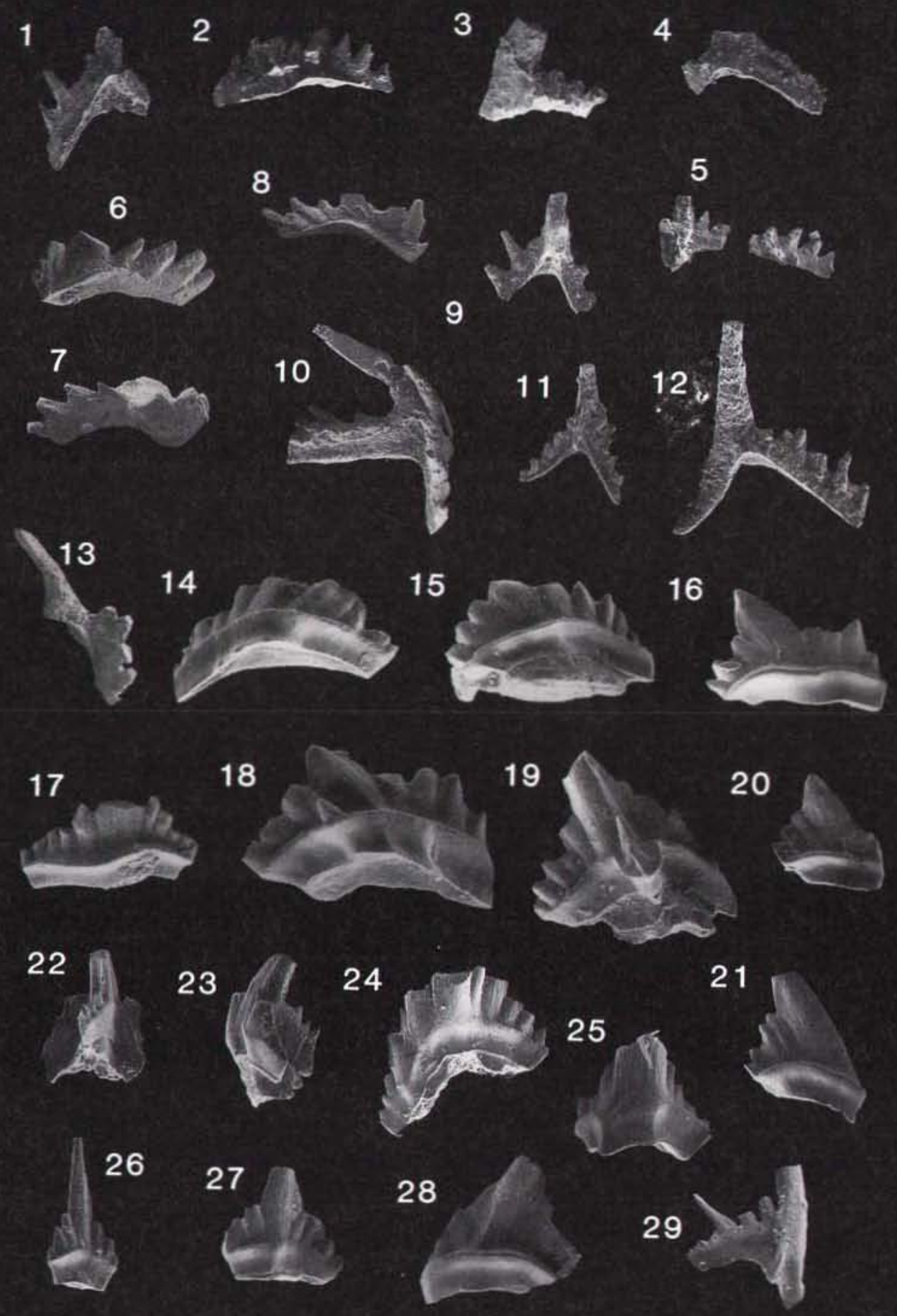


all the processes as a narrow groove. White matter distribution is as described for the other elements.

$? S b_{2}$ element. Modified tertiopedate element with a single outer antero-lateral process. The cusp is tall, posteriorly recurved, and laterally compressed; it is extended slightly, postero-basally. The outer-lateral process is inclined steeply downwards and bears four compressed denticles. The basal cavity forms a narrow groove beneath the cusp and lateral process. White matter is distributed as in the other elements.

Sc element. Bipennate element, dominated by a posteriorly recurved cusp; antero-lateral and posterior processes diverge from its edges. The antero-laterally directed process is sharply downturned and twisted posteriorly; it bears up to four long, slender, discrete, compressed denticles. The posterior process extends horizontally from the base of the cusp bearing up to four posteriorly inclined and closely packed denticles; this process is usually longer than the anterior process. The basal cavity is narrowly expanded beneath the cusp extending as a narrow groove to the tips of the processes. White matter distribution is again similar to that of the other elements.

Remarks. This species is based upon the elements from a single sample. These are well preserved and show similar denticulation, basal cavity morphology and white matter distribution which allows their reconstruction into a single apparatus. The ? $\mathrm{Sb}_{2}$ element (plate 4 , fig. 13) is similar to the Sd element of $A$. fluegeli but has a more strongly laterally compressed cusp, a laterally restricted basal cavity and differs in the wider spaced denticles. This element has a similar morphology to the ?M element of Icriodella discreta Pollock, Rexroad \& Nicoll sensu Aldridge \& Mohamed (1982, pl. 1, fig. 15). It differs in having a more sharply posteriorly curved antero-lateral process; the basal cavity is also less broadly flared beneath the cusp.

Occurrence. Found in GGU sample 216809, from the Kap Independence Member of the Hauge Bjerge Formation of Washington Land.

\section{Genus Astropentagnathus Mostler, 1967}

Type species. Astropentagnathus irregularis Mostler, 1967, p. 298.

Emended diagnosis. Apparatus septimembrate; $\mathrm{Pa}_{1}$ stelliscaphate with a bifurcate outer-lateral process and anteriorly directed inner-lateral process. $\mathrm{Pa}_{2}$ pastiniscaphate; $\mathrm{Pb}$ anguliscaphate, $\mathrm{M}$ pyramidal; $\mathrm{Sa}$ alate; $\mathrm{Sb}$ modified tertiopedate lacking a posterior process; Sc bipennate. The ramiform elements are characterised by deep lateral processes.

Remarks. Astropentagnathus was originally described by Mostler (1967) on the basis of the $\mathrm{Pa}_{1}$ element alone. Bischoff (1986, p. 156-157) emended the generic diagnosis to include $\mathrm{Pa}, \mathrm{Pb}, \mathrm{M}, \mathrm{Sa}$ and $\mathrm{Sb}$ elements.

The inclusion herein of the $\mathrm{Pa}_{2}$ element in the apparatus of Astropentagnathus follows Schönlaub (1971, p. 43 ) and is based upon its common occurrence with the other elements and shared morphological characters with the $\mathrm{Pa}_{1}$ element, for example white matter distribution and denticulation.

Astropentagnathus is distinct from Aulacognathus Mostler in having $\mathrm{Pa}$ elements with a centrally situated nodose carina along each process. The lateral processes of the Pa element of Aulacognathus species bear irregular rows of sinuous ridges. $\mathrm{A} \mathrm{Pa}_{2}$ element has not been recognised in the apparatus of Aulacognathus, and the remaining elements are readily distinguishable (figs 30 , 31).

Mostler (1967, p. 301 , fig. 4) proposed a phylogeny in which Astropentagnathus was the common ancestor of Apsidognathus and Aulacognathus. In Greenland and on Anticosti Island (Uyeno \& Barnes, 1983) Aulacognathus occurs in Telychian strata before the first appearance of Pterospathodus celloni, Astropentagnathus and Apsidognathus do not appear until the base of the $P$. celloni Biozone becoming abundant during the middleupper $P$. celloni Biozone. On stratigraphical evidence the phylogeny suggested by Mostler (1967) cannot be sustained. It is more probable from apparatus structure that Astropentagnathus is closely related to Amorphognathus and Apsidognathus and that Aulacognathus has a separate ancestory.

\section{Astropentagnathus irregularis Mostler, 1967}

Remarks. Two subspecies of Astropentagnathus irregularis are present in Greenland. The nominate subspecies occurs in the P. celloni Biozone across the whole of Greenland. A. irregularis $\mathrm{n}$. ssp. is distinguished by its morphologically distinct $\mathrm{Pa}_{2}$ element and has been found only in the P. celloni Biozone of Hans Egede Land; it is probable that this subspecies is a geographical variant of the nominate subspecies. 
Astropentagnathus irregularis irregularis Mostler, 1967

Plate 5, figs $1-10$

*1967 Astropentagnathus irregularis, p. 298, pl. 1, figs $1-11$.

1967 Spathognathodus tyrolensis Mostler, p. 302, pl. 1, figs $17,19,20,23$.

1971 Hadrognathus irregularis; Schönlaub, p. 42, pl. 1, figs 1-11.

p1971 Hadrognathus ceratoides; Schönlaub, p. 43, pl. 1, figs $12,13,16,19$ only.

1971 'Rhynchognathus' n. sp. Schönlaub, p. 48, pl. 3, figs 15-19.

1971 Falcodus? n. sp. Schönlaub, p. 47, pl. 3, figs $1-3$

1971 Synprioniodina typica Schönlaub, p. 49, pl. 3, figs 4-5.

v1972 Astropentagnathus irregularis; Aldridge, p. 166, pl. 2 , fig. 5 .

v1975 Astropentagnathus irregularis; Aldridge, pl. 3, fig. 14.

1976 Neospathognathodus tyrolensis; Miller, fig. 8, no. 37.

1976 Hadrognathus irregularis; Miller, fig. 8, no. 38.

1976 Ozarkodina media; Miller, fig. 8, no. 35.

1978 Pterospathodus tyrolensis; Miller, p. 341, pl. 4, figs 5,6 .

1981 Astropentagnathus irregularis; Uyeno \& Barnes, pl. 1, fig. 13.

1983 Astropentagnathus irregularis; Nowlan, fig. 4D.

v1985 Astropentagnathus irregularis; Aldridge, pl. 3.2, fig. $1,2$.

1986 Astropentagnathus irregularis; Bischoff, p. 158, pl. 2, figs 27-29; pl. 3, figs 1-14.

1987 Astropentagnathus irregularis; Over \& Chatterton, pl. 2, figs 1-9.

Holotype. Astropentagnathus irregularis Mostler, p. 298, pl. 1, fig. 3, from Westendorf Schicht, Wi 19.

Emended diagnosis. Septimembrate apparatus characterised by its pastiniscaphate $\mathrm{Pa}_{2}$ element which has a single centrally situated outer process and lacks an inner process.

Description. $P a_{1}$ element. Stelliscaphate with a bifurcating outer-lateral process and anteriorly directed innerlateral process, all processes have a narrow ledge-like platform, the margin of which may be upturned or differentially thickened. The anterior process is straight and bears fourteen nodose, fused denticles. The posterior process is shorter and curved inwards; at the point of maximum curvature it may have a slightly larger denticle. The outer-lateral process diverges close to the midpoint of the carina and bifurcates at the first proximal denticle. The branches of the process are separated by an angle of $90^{\circ}$. The postero-lateral process is longer and bears nodes. The inner lateral process is situated just anterior of the outer-lateral process, diverging from the carina at approximately $45^{\circ}$ and bears a central carina of up to three nodes. In small specimens the position of this process is marked by a flexure or slight thickening of the lateral platform. The entire lower surface is shallowly excavated. White matter distribution for all elements is illustrated in fig. $\mathbf{3 0 .}$

$\mathrm{Pa}_{2}$ element. Pastiniscaphate with a single outer-lateral process situated just posterior of the midlength; a narrow platform is developed around all the processes. The anterior and posterior processes bear a continuously inwardly curving carina of up to seventeen fused, nodose denticles. The posterior process may be more sharply inwardly flexed just posterior of the outer-lateral process (plate 5, fig. 2). On many specimens a slight extension of the inner side of the platform is evident just to the posterior of the junction of the outer process. This may represent the incipient development of an inner-lateral process. The basal cavity is deep and tapers distally along the anterior, posterior and outerlateral processes, terminating before the process tip.

$\mathrm{Pb}$ element. Angulate or pastinate; laterally compressed and arched. A prominent posteriorly inclined cusp lies posterior of the midpoint. The anterior process is straight and bears up to eight almost completely fused denticles. The posterior process is shorter and lower than the anterior process; it bears three to four denticles. A short inner-lateral process may be developed beneath the anterior edge of the cusp. This process bears one or two rudimentary denticles. The basal cavity is narrowly flared beneath the cusp, tapering rapidly to form a narrow groove beneath the anterior and posterior processes, extending to their tips. A broader groove extends to the tip of the inner-lateral process.

$M$ element. Modified alate to tertiopedate (rarely) subpyramidal element. The short cusp is round in cross section and posteriorly recurved. Beneath the cusp the element is deep, broadly flared and triangular in cross section. The lateral edges of the cusp are denticulate, the inner bears four almost completely fused denticles, the outer has only three. The base is extended posteriorly to form a sharp adenticulate process; the postero-lateral faces of the base are slightly concave. The entire lower surface is deeply excavated. In large collections asymmetrical examples of this element are present; these forms have the inner-lateral process situated and directed further towards the posterior.

Sa element. Alate, cusp prominent and lenticular in cross section; long deep lateral processes extend from its edges symmetrically, forming an arch of $120^{\circ}$ between the lower edges of the processes. Each process bears up to eight compressed, tall denticles which are fused almost to their tips. Occasionally in large specimens (plate 5, fig. 8) a short triangular projection is directed posteriorly and downwards beneath the cusp. 
The basal cavity is shallowly excavated, restricted to beneath the cusp and oval in lower outline.

Sb element. Asymmetrically arched, modified alate element. The small cusp is lenticular in cross section and inclined towards the commonly shorter inner-lateral process. In posterior view the processes form an asymmetrical arch of about $80^{\circ}$ between their lower edges, the outer process is more steeply inclined than the inner. Both processes bear up to seven compressed denticles, the most proximal of these are fused, the most distal are generally discrete. The basal cavity is restricted to beneath the cusp and is deeply excavated with its anterior and posterior tips expanded slightly.

Sc element. Bipennate with a deep, slightly inwardly curved anterior process. The cusp is broad, posteriorly inclined and lenticular in cross section. The anterior process is approximately twice as deep as the posterior process, bearing up to eight almost completely fused denticles. The anterior process is downturned forming an angle of about $110^{\circ}$ with the posterior process. The posterior process bears up to eight denticles, the most proximal is larger than the rest and is completely fused to the cusp. The basal cavity is deeply excavated, expanded beneath the cusp extending as an extremely narrow groove almost to the tips of the unit.

Remarks. Ramiform elements figured by Schönlaub (1971) are here included in the apparatus of $A$. irregularis irregularis, on the basis of samples from Greenland, figured material from Schönlaub's samples Seewarte 194/3 and 194/4, and additional material from Seewarte collected by R. J. Aldridge. The inclusion of 'Rhynchognathus' n. sp. Schönlaub (1971) as the M element was first suggested by Klapper \& Murphy (1975). Bischoff (1986) emended the generic diagnosis based upon partial reconstruction of $A$. irregularis; this has been expanded for the septimembrate plan herein. Over \& Chatterton (1987) illustrated a partial reconstruction of the apparatus of $A$. irregularis. They in- cluded two dissimilar $\mathrm{Pb}$ elements in the apparatus, but this cannot be confirmed in the collections studied.

Occurrence. Particularly common in the P. celloni Biozone of Washington Land.

\section{Astropentagnathus irregularis n. ssp.}

Plate 5, figs 11-15

Description. Pa $a_{1}$ element. Indistinguishable from that of A. irregularis irregularis.

$\mathrm{Pa}_{2}$ element. Stelliplanate with anteriorly directed lateral processes, juxtaposed centrally, each inserted at an angle of $45^{\circ}$ to the main carina. The anterior and posterior processes are of equal length; the central carina is straight and becomes poorly denticulated to the anterior of the lateral processes. The two most anterior denticles are approximately twice as high as the others. Centrally the carina forms a low, rounded, adenticulate ridge, and posteriorly it curves inwards and downwards following the posterior process, bearing up to ten poorly formed, fused, nodose denticles. The entire element is surrounded by a narrow ledge-like platform which is upturned marginally. Beneath the platform the element narrows slightly and has an excavated cavity. This is completely infilled with basal material in all specimens.

$M$ element. Modified tertiopedate, subpyramidal element, the short posteriorly recurved cusp has a circular cross section. The lateral edges of the triangular base are denticulate and extend downwards to form short processes, each bears up to ten poorly formed tooth-like denticles. Posteriorly the base of the cusp is extended downwards terminating as a short adenticulate process; the postero-lateral faces of the element are flat to slightly concave. The entire lower surface is deeply excavated.

Sa element. Alate with a slight posterior swelling at the base of the cusp. A large antero-posteriorly com-

\section{Plate 5}

Figs 1-10. Astropentagnathus irregularis irregularis Mostler. All specimens from GGU 216809 , unless otherwise stated.

1, upper view of $\mathrm{Pa}_{1}$ element, $\times 60$; MGUH 17.632.

2 , upper view of $\mathrm{Pa}_{2}$ element, $\times 40$; MGUH 17.633 .

3,4 , inner-lateral and oblique lateral views of $\mathrm{Pb}$ element, $\times$ 60; MGUH 17.634.

5, inner-lateral view of $\mathrm{Pb}$ element, $\times 60$; MGUH 17.666.

6 , lateral view of $M$ element, $\times 60$; MGUH 17.636.

7 , posterior view of $\mathrm{M}$ element, $\times 60$; MGUH 17.635.

8, posterior view of Sa element, $\times 60$; MGUH 17.637 from GGU 256360 .
9, posterior view of Sb element, $\times 60$; MGUH 17.638. 10 , posterior view of Sc element, $\times 60 ;$ MGUH 17.639.

Figs 11-15. Astropentagnathus irregularis n. ssp. All specimens from GGU 197564.

11, upper view of $\mathrm{Pa}_{1}$ element, $\times 60$; MGUH 19.329.

12 , upper view of $\mathrm{Pa}_{2}$ element, $\times 20$; MGUH 19.330.

13 , posterior view of $\mathrm{M}$ element, $\times 60$; MGUH 19.331 .

14, posterior view of Sa element, $\times 60$; MGUH 19.332.

15 , posterior view of Sb element, $\times 60$; MGUH 19.333. 


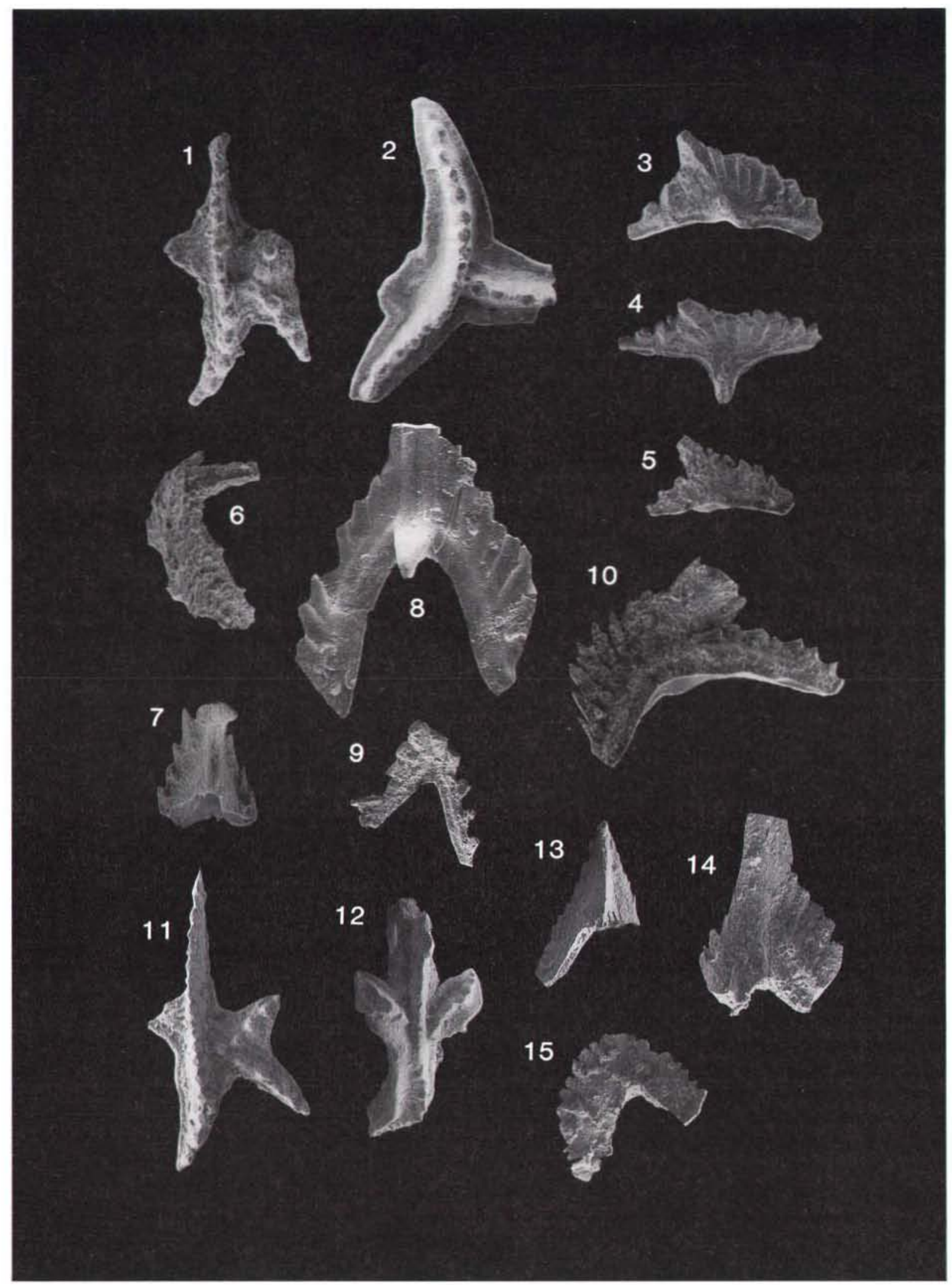


pressed cusp dominates the deep lateral processes; the inner process is usually the shallower of the two. Each process bears laterally compressed, outwardly inclined, fused denticles. The basal cavity is oval in lower outline, shallowly excavated, extending as a groove only a short distance along the processes.

$S b$ element. Only poorly preserved specimens are present. This element is an asymmetrical version of the Sa element with the cusp inclined towards the shorter inner-lateral process. Smaller, fewer denticles are situated on the inner-lateral process.

Remarks. The major difference between this and the nominate subspecies lies in the morphology of the $\mathrm{Pa}_{2}$ element. Minor differences do occur between the other elements. The $\mathrm{M}$ element of $A$. irregularis $\mathrm{n}$. ssp. has a broader, more steeply triangular base to the cusp and short lateral processes which extend below the basal margin of the posterior process. The $\mathrm{S}$ elements in this new subspecies have deeper lateral processes and more prominent cusps.

Occurrence. Found only in GGU 197564.

\section{Genus Aulacognathus Mostler, 1967}

1967 Aulacognathus Mostler, p. 300.

1969 Neospathognathodus Nicoll \& Rexroad, p. 42.

Type species. Aulacognathus kuehni Mostler, 1967, p. 300 ; from the Llandovery of Westendorf, Kitzbühl Alps, Austria.

Emended diagnosis. Apparatus seximembrate characterised by a highly variable stelliscaphate $(\mathrm{Pa})$ element which has irregularly nodose or ridged inner and outerlateral processes. Anteriorly the carina is free, posteriorly it is inwardly bent and occasionally thickened. The anguliscaphate $(\mathrm{Pb})$ element occasionally develops a short inner-lateral process beneath the cusp. Tertiopedate $(\mathrm{M})$ element has a reduced posterior process; the alate (Sa) element, asymmetrical modified alate ( $\mathrm{Sb})$ and bipennate $(\mathrm{Sc})$ elements have a small oval basal cavity restricted to beneath the cusp.

Remarks. Klapper \& Murphy (1975, p. 25) placed Aulacognathus and Neospathognathodus Nicoll \& Rexroad, 1969 , in synonymy based on the similarity of the $\mathrm{Pa}$ elements in their constituent type species. As noted by Aldridge $(1979$, p. 10) the recognition of almost identical $\mathrm{Pb}$ elements in A. kuehni, A. bullatus and A. latus strengthens this synonymy. Bischoff (1986) considered the apparatus of Aulacognathus to be bimembrate. $\mathrm{He}$ also separated five new species of Aulacognathus based upon upper surface ornament and the disposition of the anterolateral and posterior processes. The former character appears very variable in Greenland species and insufficient specimens are available to judge intraspecific variability. $\mathrm{M}, \mathrm{Sa}, \mathrm{Sb}$ and $\mathrm{Sc}$ elements have been included based on collections of $A$. bullatus from Greenland and Illitsch Hof 12 (fig. 31).

\section{Aulacognathus bullatus (Nicoll \& Rexroad,} 1969)

Plate 6 , figs $1-2,4-7$

v1964 Spathognathodus sp. ex. aff. Spathognathodus celloni Walliser; Walliser, p. 74, pl. 14, figs 17, 18.

v*1969 Neospathognathodus bullatus p. 44, pl. 1, figs 5-7.

1971 Neospathognathodus bullatus; Rexroad \& Nicoll, pl. 1, fig. 7 .

1971 Neospathognathodus ceratoides; Rexroad \& Nicoll, pl. 1, fig. 6 .

v1972 Neospathognathodus bullatus; Aldridge, p. 126 , pl. 3, fig. 15.

1975 Aulacognathus bullatus; Klapper \& Murphy, p. 26 , pl. 2 , figs $15-20$.

?1975 Aulacognathus ceratoides; Klapper \& Murphy, p. 26 , pl. 1 , figs $4,5,8-14$.

\section{Plate 6}

Figs 1, 2, 4-7. Aulacognathus bullatus (Nicoll \& Rexroad).

1, upper view of Pa element, $\times 60$; MGUH 17.667 from GGU 216773.

2, upper view of Pa element, $\times$ 60; MGUH 17.668 from GGU 274770.

4, 5, upper side and inner-lateral views of $\mathrm{Pb}$ element, $\times 40$; MGUH 17.669 from GGU 274770.

6 , posterior view of Sa element, $\times 60$; MGUH 17.670 from GGU 229037.

7, inner-lateral view of Sc element, $\times 60$; MGUH 17.671 from GGU 229037.
Figs 3, 8, 9. Aulacognathus latus (Nicoll \& Rexroad).

3, upper view of Pa element, $\times$ 60; MGUH 17.672 from GGU 216773.

8, upper view of Pa element, $\times$ 40; MGUH 17.673 from GGU 275048.

9. upper view of Pa element, $\times$ 40; MGUH 14.037 from GGU 184125.

Fig. 10. Aulacognathus sp.

10 , lateral view of $\mathrm{Pb}$ element, $\times 40$; MGUH 17.674 from GGU 229037. 

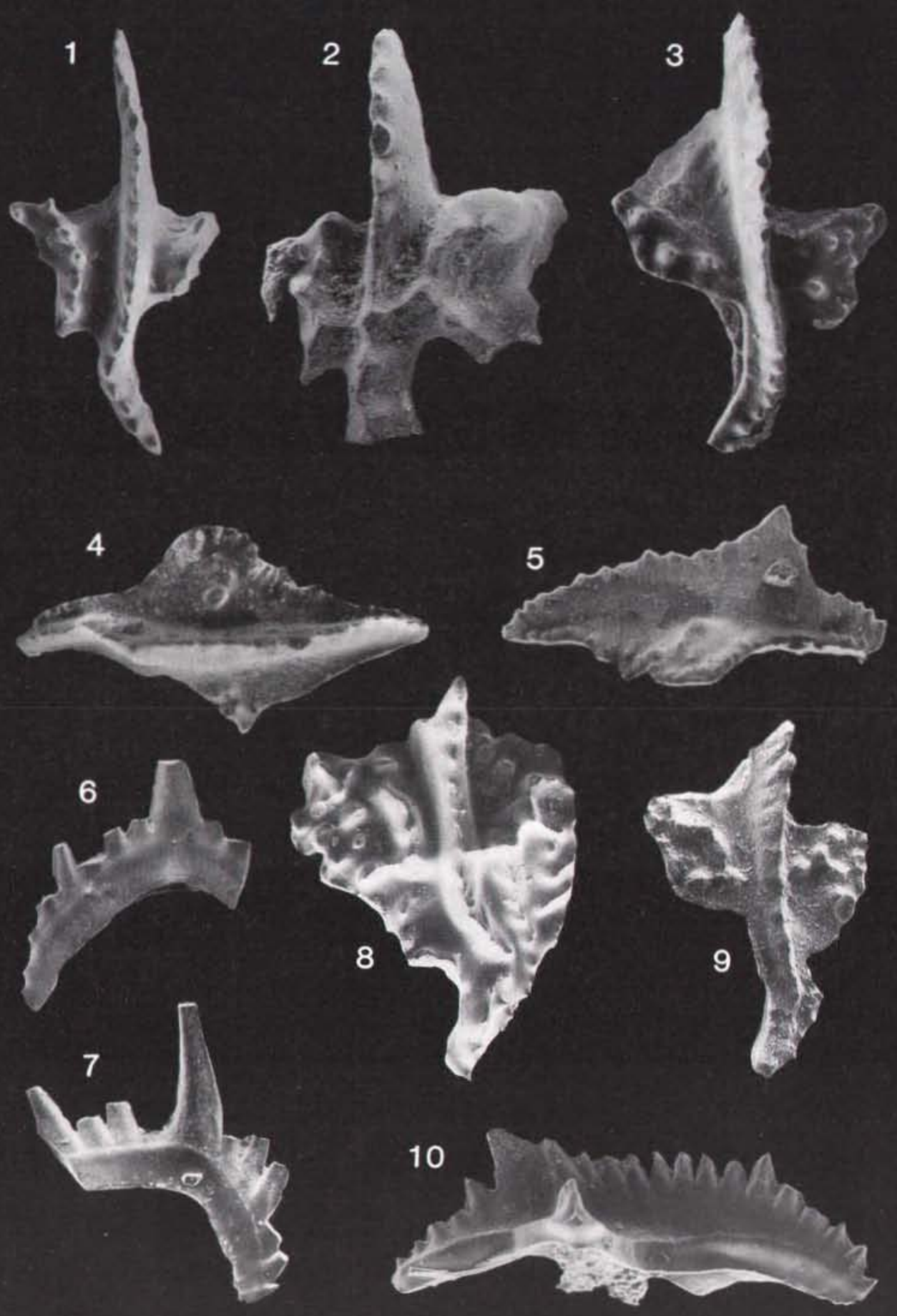
1975a Neospathognathodus bullatus; Schönlaub, p. 59, pl. 1, fig. 6 .

1978 Neospathognathodus latus; Pickett, pl. 1, fig. 31

v1979 Aulacognathus bullatus; Aldridge, pl. 11, figs 1, $6,7$.

1979 Aulacognathus bullatus; Murphy, Dunham, Berry \& Matti, fig. 19 , no. 3 .

p1981 Aulacognathus bullatus; Nowlan, pl. 5, figs 20, 24 ; non 23.

1983 Aulacognathus bullatus; Nowlan, figs 4E, 40, 4P.

1987 Aulacognathus bullatus; Over \& Chatterton, pl. 3, figs $1,2,6$.

Holotype. Neospathognathodus bullatus Nicoll \& Rexroad, 1969, p. 44, pl. 1, fig. 5; from sample M-Z II, Lee Creek Member of the Brassfield Limestone, Indiana.

Emended diagnosis. Apparatus seximembrate; diagnostic stelliscaphate $(\mathrm{Pa})$ element with limited platform development and a long carina which is free to the anterior and posterior of the platform. Inner and outer, anteriorly directed, lateral processes are broad and bear an ornament of irregular coalescing nodes or low sinuous ridges.

Description. Pa element. A highly variable stelliscaphate element comprising a long blade-like carina and broad anteriorly directed inner and outer processes. The carina bears up to 24 , partially fused nodose denticles and is sharply incurved at approximately two-thirds the length from the anterior tip, a secondary denticle may be developed here. The ornament of the lateral processes is highly variable from coalescing nodes to
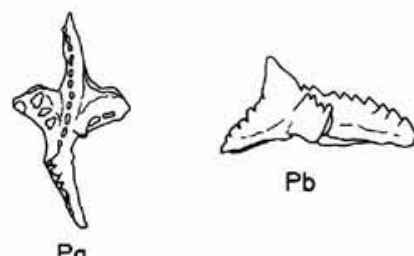

$\mathrm{Pb}$

$\mathrm{Pa}$

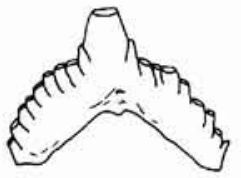

Sa

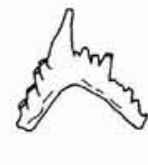

$\mathrm{Sb}$

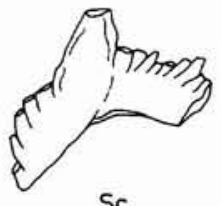

Sc
Fig. 31. The apparatus of Aulacognathus bullatus (Nichol \& Rexroad). All the specimens are from Illitsch 12 . Total specimens in the sample: $\mathrm{Pa}, 24 ; \mathrm{Pb}, 15 ; \mathrm{M}, 10 ; \mathrm{Sa}, 16 ; \mathrm{Sb}, 4 ; \mathrm{Sc}, 3$. Specimens kindly provided by R. J. Aldridge. Camera lucida drawings: Pa, MGUH $17.790 \times 20 ; \mathrm{Pb}$, MGUH $17.924 \times 20$; M, MGUH $17.930 \times 28$; Sa, MGUH $17.866 \times 28 ;$ Sb, MGUH $19.310 \times 28 ;$ Sc, MGUH $19.311 \times 20$. irregular sinuous and bifurcating ridges. The inner process commonly develops into two ornamented lobes. Both lateral processes are broad and form the narrow platform of this element. The entire lower surface is shallowly excavated.

$\mathrm{Pb}$ element. Anguliscaphate with a prominent apical denticle, long anterior process and short posterior process. The anterior process bears up to 15 almost completely fused denticles, the posterior process only five or six denticles. Laterally extended basally, the element may develop a narrow platform (plate 6 , figs 4,5 ) or may be narrow and blade-like, only slightly thickened (see Aldridge, 1979, pl. 1, figs 2, 3). In the platform specimens a small indistinct anteriorly directed innerlateral process may be developed beneath the apical denticle; the platform margin may also bear discrete nodes or ridges. The entire lower surface is excavated.

$M$ element (from Illitsch Hof 12; fig. 31). Pyramidal, modified tertiopedate element, with prominent compressed cusp. The inner-lateral process is longer than the outer and bears up to five partially fused denticles, the outer process commonly only has two or three small, rudimentary peg-like denticles. The posterior process is commonly reduced to a slight swelling beneath the cusp and rarely develops into a short denticulate process. The basal cavity is broad beneath the cusp and tapers rapidly along the lateral processes, terminating before their tips.

Sa element. Broadly arched alate element with a slight posterior swelling beneath the base of the cusp. Cusp erect, tall, antero-posteriorly compressed, lenticulate in cross section. Long, deep lateral processes extend from its base, each bearing up to eight, compressed, partially fused denticles. Both processes are slightly thickened below the denticle row. The basal cavity is only slightly expanded beneath the cusp, extending as a rapidly narrowing groove terminating beneath the first proximal denticle on each lateral process.

$S b$ element (from Illitsch Hof; fig. 31). Modified tertiopedate element, lacking a posterior process. The cusp is lenticular in cross section and inclined towards the inner-lateral process. The lateral processes form an angle of approximately $120^{\circ}$ between their lower edges. The inner process is the longer and less steeply inclined, bearing up to 11 , partially fused, compressed denticles; the outer process bears only four denticles. The basal cavity forms a narrow groove which terminates before the midlength of the lateral processes.

$S c$ element. Bipennate with tall, laterally compressed, posteriorly inclined cusp. The anterior process is steeply downwards inclined forming an angle of approximately $110^{\circ}$ with the base of the posterior process. The anterior process bears up to six compressed, partially fused den- 
ticles. The posterior process is slightly longer than the anterior, more or less horizontal and bears 10-15 partially fused denticles. Both processes are slightly thickened beneath the denticle row. The basal cavity is only slightly expanded beneath the cusp and extends as a narrow groove, only a short distance along the process.

Remarks. The apparatus recognised here is reconstructed from the Greenland collection with the help of additional material from the research collections of $\mathbf{R}$. J. Aldridge, particularly from sample 'Illitsch Hof 12', collected by J. Barrick from Schönlaub's locality 12 (Sweet \& Schönlaub, 1975; Schönlaub, 1975a). This sample contains abundant elements representing the complete apparatus of $A$. bullatus (fig. 31), all specimens are thermally mature and white matter is not visible. The reconstruction presented is in agreement with that present in slides sorted by Aldridge.

Aldridge (1979, p. 11) discussed fully the difficulty in assigning a $\mathrm{Pb}$ element to this apparatus. A. bullatus is the most common Aulacognathus species in the Greenland collection, and $\mathrm{Pb}$ elements are assigned to this species unless $A$. latus occurs in the samples.

Nowlan (1981, pl. 5, figs 2, 3) included an M element in his illustrations of $A$. bullatus. This specimen is morphologically distinct from that included here, resembling the morphology of an Ozarkodina M element. Rare specimens (plate 6, fig 2) approach the morphology of $A$. bullatus n. ssp. A Over \& Chatterton (1987, p. 20 , pl. 3, fig. 3). Due to the highly variable nature of the $\mathrm{Pa}$ element these may fall within the morphological range of $A$. bullatus. Insufficient specimens are available in the Greenland collection to confirm this separation.

Occurrence. In eastern Peary Land this species occurs in just pre-P. celloni Biozone strata, elsewhere it occurs infrequently in $P$. celloni Biozone strata. Outside Greenland $A$. bullatus has been recorded from $P$. celloni Biozone strata of Australia, Canada, Europe and North America. On Anticosti Island this species also occurs before the first appearance of Pterospathodus celloni (Walliser), though restricted to the lower Telychian (Uyeno \& Barnes, 1983).

\section{Aulacognathus latus (Nicoll \& Rexroad, 1969)}

Plate 6, figs 3, 8-9

\footnotetext{
v*1969 Neospathognathodus latus, p. 46, pl. 1, figs 8-11.

1972 Neospathognathodus latus; Rexroad \& Nicoll, pl. 2 , fig. 41 .

1975 Aulacognathus latus; Klapper \& Murphy, p. 26, pl. 1 , figs 6,7 .
}

1977a Aulacognathus latus; Cooper, p. 1063, pl. 2, figs $2,10$.

?1977a Aulacognathus latus; Cooper, p. 1063, pl. 2, figs 1,5 .

v1979 Aulacognathus latus; Aldridge, p. 12, pl. 1, figs 4,5 .

Holotype. Neospathognathodus latus Nicoll \& Rexroad, 1969 , p. 46 , pl. 1, fig. 11; from the Lee Creek Member of the Brassfield Limestone, Kentucky.

Remarks. Known in Greenland only from rare specimens of the Pa element. These differ little from those described by Nicoll \& Rexroad (1969, p. 46). This species differs from that of $A$. bullatus in having a $\mathrm{Pa}$ element with a low, broad platform, which has an ornament of well developed nodes. GGU 275048 contains an atypical $\mathrm{Pa}$ element whose platform ornament consists of high, sinuous branching ridges (plate 6 , fig. 8). Insufficient complete specimens are available to make a taxonomic separation of this form.

Occurrence. A. latus $\mathrm{Pa}$ elements are found in upper $P$. celloni Biozone strata of North Greenland. Cooper (1977a, p. 1063) recorded the range of this species as lower P. celloni Biozone to lower P. amorphognathoides Biozone.

\section{Genus Belodella Ethington, 1959}

Type species. Belodus devonicus Stauffer, 1940, p. 420.

Diagnosis. Refer to Barrick, 1977, p. 49.

Remarks. Belodella has been recorded from the early Ordovician to late Devonian (Cooper, 1974 for a review). The $B$. jemtlandica apparatus figured by Löfgren (1978, p. 46, fig. 24, following Carnes, 1975) from the Lower Ordovician contains a denticulate, triangular sym. p element, a denticulate aq, an adenticulate sq and an oistodiform $r$ element. B. erecta Rhodes \& Dineley sensu Löfgren (1978, fig. 24, E-H) from the upper Ordovician has a similar apparatus structure, but differs in having a denticulate sq element. Serpagli (1967) described specimens from the upper Ordovician strata of the Carnic Alps, which he identified as $B$. devonica and $B$. erecta Rhodes \& Dineley (1953) but did not combine in a single apparatus. Cooper $(1974,1976)$ interpreted the apparatus of Belodella from the Upper Silurian to consist of two element types, both with denticulate upper edges, one has a triangular cross section, the other has a lenticular cross section. These elements conform to the general morphology of the specimens referred to B. triangularis and B. devonicus by Stauffer (1940). 
Ethington \& Clark (1982) reported large collections of Belodella from the Tor limestone (Toquima Range, central Nevada) which overwhelmingly supported Cooper's reconstruction of the apparatus. Klapper \& Philip (1972, p. 104) and Barrick (1977, p. 49) have suggested the inclusion of an adenticulate element in the apparatus of middle Silurian Belodella. Elements conforming to their descriptions have been reported from Devonian samples (Bultynck, 1970; Seddon, 1970), but such adenticulate elements have neither been recognised in the collections of Cooper $(1974,1976)$ and Ethington \& Clark (1982) nor from Greenland.

The apparatus reconstruction as proposed herein has constituent elements similar to those of Walliserodus Serpagli, exhibiting similar basal cavity outline, microstriation and element curvature; a close morphological relationship obviously exists between these two genera. Elements conforming to the adenticulate morphotype may have been misidentified, but I think this is unlikely in the three separate collections described above.

Thus it appears that the Ordovician, Silurian and Upper Silurian through Devonian apparatuses referred to Belodella have different structures, and it is necessary to reconsider the relationship between them.

Two hypotheses regarding the origin of Silurian Belodella have been proposed and are summarised by Cooper $(1974,1975)$. Cooper did not consider the lower Ordovician species of Belodella as ancestors since they had not been fully described at that time. The apparatus of Belodella cooperi $\mathrm{n}$. sp. differ only from that of $B$. erecta Serpagli as reconstructed by Löfgren (1978) by the lack of the oistodiform element. The evolution of Upper Silurian $B$. devonicus may have occurred by the loss of the sq element from the B. cooperi apparatus.
With the available data the Silurian Belodella lineage is thought to be a continuation from the Ordovician rather than representing a split from the Walliserodus lineage as proposed by Cooper (1974).

\section{Belodella cooperi $\mathrm{n}$. sp.}

Plate 7, figs 1-6

Holotype. Specimen MGUH 17.883, plate 16, fig. 5 , an sq element from GGU 216849 within the upper $P$. celloni Biozone at Kap Schuchert, Washington Land, western North Greenland.

Diagnosis. A species of Belodella with a trimembrate apparatus. All elements are laterally compressed and bear upper-edge denticles.

Description. sym. p element. Indistinguishable from that described as Belodus triangularis Stauffer (1940, p. 417, pl. 59, fig. 49).

aq element. Indistinguishable from that described as Belodus devonicus Stauffer (1940, p. 417, figs 47, 48).

$s q$ element. Highly compressed, bilaterally symmetrical element. The cusp is proclined and long; the base is short and has posteriorly curved upper and lower margins; the postero-basal corner is extended posteriorly. The upper margin of the base is extended by tall, needle-like, fused denticles; the posterior margin of the cusp is very rarely denticulate. The anterior margin of the cusp and lower margin of the base are narrow and rounded, and short oblique striations are located along it. The lateral faces are flat and divided just above midheight by a step-like costa on each side. The costae

\section{Plate 7}

Figs 1-6. Belodella cooperi $\mathrm{n}$. sp. (Stauffer). All specimens from GGU $216849, \times 60$.

1, lateral view of sym. p element; MGUH 17.879.

2 , lateral view of sym. p element; MGUH 17.880.

3 , lateral view of aq element; MGUH 17.881 .

4, lateral view of aq element; MGUH 17.882.

5, lateral view of sq element; MGUH 17.883 (holotype).

6, lateral view of sq element; MGUH 17.884.

Figs 7-12. Dapsilodus obliquicostatus (Branson \& Mehl). All specimens from GGU 216842, × 60 .

7, lateral view of sym. p element; MGUH 17.885.

8, lateral view of sym. p element; MGUH 17.886.

9, lateral view of sq element; MGUH 17.887.

10 , lateral view of sq element; MGUH 17.888.

11, lateral view of $\mathrm{r}$ element; MGUH 17.889 .

12, lateral view of $\mathrm{r}$ element; MGUH 17.890.
Figs 13-17. Decoriconus fragilis (Branson \& Mehl). All specimens from GGU $216809, \times 60$.

13, lateral view of sym. p element; MGUH 17.891.

14 , lateral view of sym. p element; MGUH 17.892.

15, lateral view of sq element; MGUH 17.893.

16, lateral view of sq element; MGUH 17.894.

17. lateral view of $\mathrm{r}$ element; MGUH 17.895.

Figs 18-23. Panderodus aff. $P$. greenlandensis. All specimens from GGU $216719, \times 60$.

18, outer-lateral view of sym. p element; MGUH 17.896.

19 , inner-lateral view of sym. p element; MGUH 17.897.

20 , inner-lateral view of aq element; MGUH 17.898.

21,22 , inner and outer-lateral view of sq element; MGUH 17.899 .

23, inner-lateral view of $r$ element; MGUH 17.900 . 

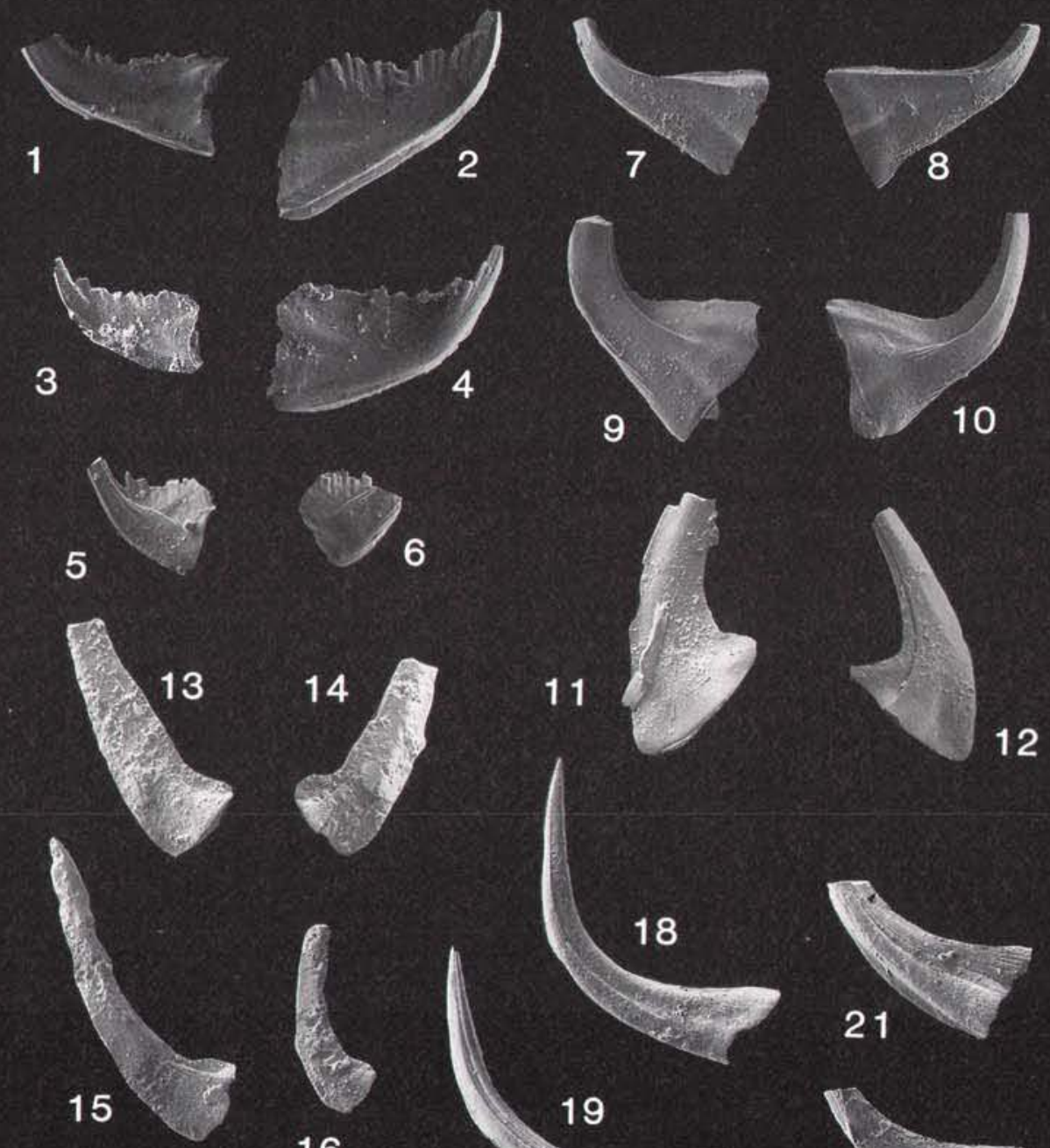

11
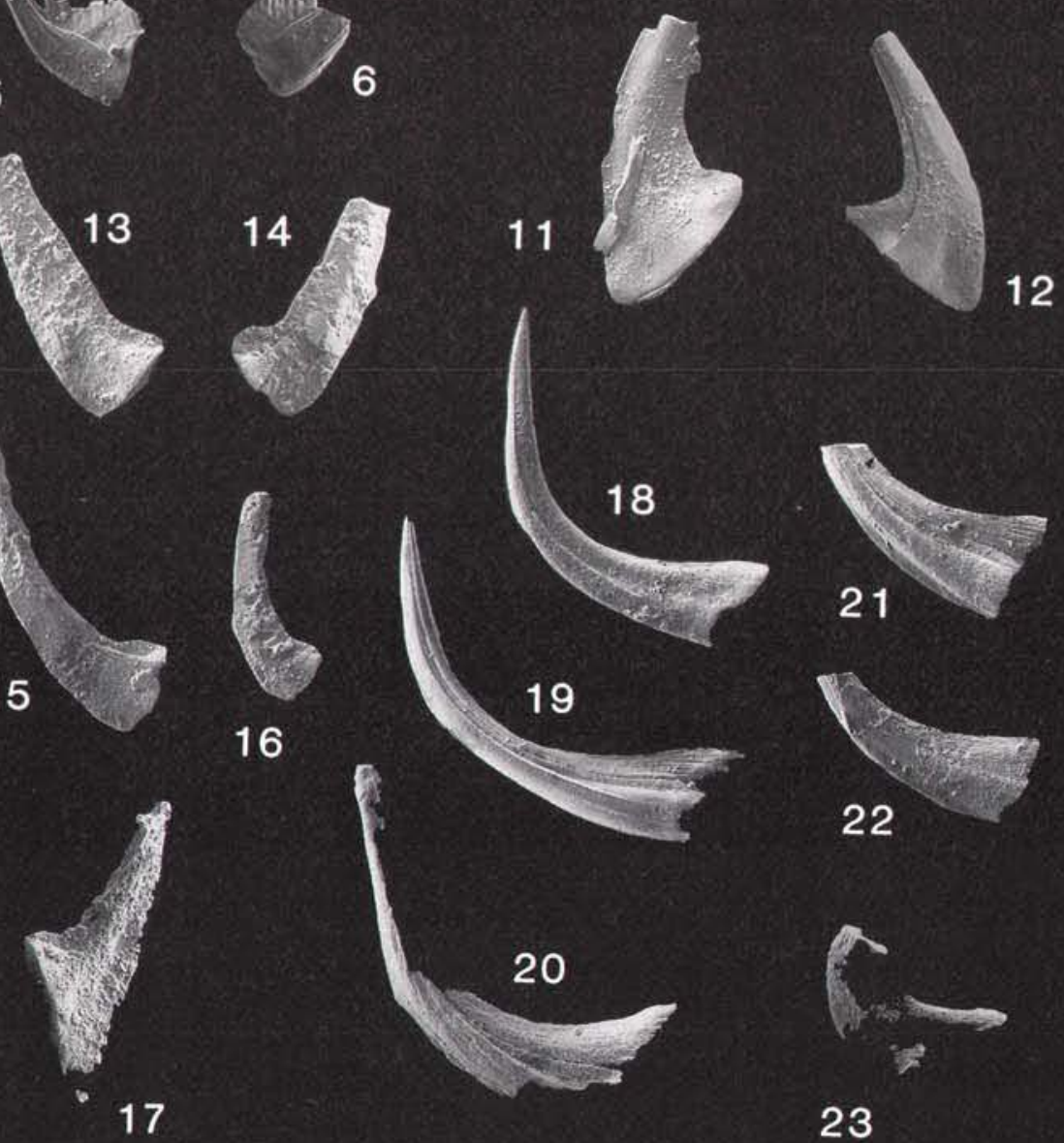

22

originate near the midlength of the base and pass apically migrating towards the upper edge of the cusp. One or two oblique secondary costae may extend downwards from a point on the primary costa, just below the base of the cusp. The basal margin is straight; excavated from the lower basal corner to the base of the denticles. In lateral view the basal cavity is short and tapers rapidly upwards, its lower margin is upwardly curved and its upper margin is more or less straight. White matter, as in the sym. p element, fills the denticles and cusp, passing down to the apex of the basal cavity.

Remarks. The apparatus of $B$. devonicus differs in lacking an sq element. Belodella cooperi differs from Belodella sp. cf. B. devonica sensu Cooper (1976) in being shorter longitudinally and having a broader basal margin. The aq element has a tendency to develop rudimentary denticles along the anterior edge of the cusp; this character is also found in the lenticular element of B. anomalis Cooper (1974), the apparatus of which has no sq element.

Occurrence. Found in all sections except for those in northern Peary Land and Kronprins Christian Land; ranges from the $P$. celloni Biozone into the upper (?) Wenlock.

\section{Genus Carniodus Walliser, 1964}

Type species. Carniodus carnulus Walliser, 1964, p. 30.

Emended diagnosis. Apparatus containing a complex of morphologically inter-related elements, the most commonly recurrent members of which are: an arched carminiplanate (carinthiaciform) element; a suite of anguliplanate (carnuliform) elements, characterised by a tall prominent cusp and short denticulate processes; a dolabrate (neoprioniodontan) element; an alate (latialatiform) element; an asymmetrically arched modified dolabrate (carniform element) and a dolaborate (subcarniform) element. All the elements are characterised by a narrow groove-like basal cavity and short fused denticles. In lateral view white matter is diffuse and fills each denticle above the midheight of the processes.

Remarks. The application of locational nomenclature obscures the complexity of the morphological transitions between the elements of $C$. carnulus and leads to an oversimplified picture of the apparatus structure. In view of this an informal terminology is applied here.
Carniodus carnulus Walliser, 1964

Plate 4 , figs $14-29$; plate 8 , figs $1-4$

v1964 ?Carniodus carinthiacus Walliser, p. 31, pl. 6, fig. 8 ; pl. 27, figs 20-26; text fig. $4 \mathrm{n}$.

v*1964 Carniodus carnulus, p. 32, pl. 6, fig. 10; pl. 10, figs 20,21 ; pl. 27 , figs $27-38$; pl. 28 , fig. 1 ; text figs $4 \mathrm{a}-\mathrm{f}$.

v1964 Carniodus carnicus Walliser, p. 32, pl. 6, fig. 11; pl. 28, figs 8-11.

v1964 Neoprioniodus subcarnus Walliser, p. 51, pl. 5, fig. 7 ; pl. 28 , figs $12-18$.

v1964 Roundya latialata Walliser, p. 71, pl. 6, fig. 15; pl. 31, figs 11-14.

v1964 Carniodus carnus Walliser, p. 34, pl. 5, fig. 3; pl. 10 , fig. 13 , pl. 28 , fig 2 ; text figs $4 y-z$.

1966 ?Carniodus carinthiacus; Spasov \& Filipović, p. 38 , pl. 1, fig. 3 .

1966 Carniodus carnulus; Spasov \& Filipović, p. 39, pl. 1 , fig. 15.

1966 Carniodus carnicus; Spasov \& Filipović, p. 38, pl. 1, fig. 16.

1966 Roundya brevialata; Spasov \& Filipović, p. 49, pl. 1, fig. 14.

1966 Carniodus carnus; Spasov \& Filipović, p. 40, pl. 1, figs 12,13 .

1966 Neoprioniodus subcarnus; Spasov \& Filipović, p. 42 , pl. 1 , figs 8,9 .

1966 Carniodus carinthiacus; Spasov, pl. 1, fig. 3.

1967? Carniodus carinthiacus; Flajs, pl. 4, figs 2, 3.

1967 Carniodus carnicus; Flajs, pl. 4, fig. 4.

?1968 Carniodus carinthiacus; Igo \& Koike, p. 8, pl. 3, figs 2,3 .

1969 Carniodus carinthiacus; Nicoll \& Rexroad, p. 24, pl. 5, figs 1,2 .

v1969 Carniodus carnulus; Nicoll \& Rexroad, p. 25, pl. 5 , figs 4,5 .

pv1969 Carniodus carnus; Nicoll \& Rexroad, p. 26, pl. 5, figs 6,8 only.

v1969 Neoprioniodus subcarnus; Nicoll \& Rexroad, p. 41 , pl. 5 , fig. 10 .

1969? Carniodus carinthiacus; Schönlaub, pl. 1, fig. 12.

1969 Carniodus carnulus; Schönlaub, pl. 1, fig. 5.

1969 b Carniodus? carinthiacus; Drygant, p. 54, pl. 1, fig. 5.

1969 b Neoprioniodus subcarnus; Drygant, p. 53, pl. 1, figs $12-14$.

p1971 Carniodus carinthiacus; Schönlaub, p. 46, pl. 3, figs 7-8.

1972 Carniodus carinthiacus; Rexroad \& Nicoll, pl. 2, fig. 1-3.

1972 Carniodus carnicus; Rexroad \& Nicoll, pl. 2, figs 4-5.

1972 Carniodus carnulus; Rexroad \& Nicoll, pl. 1, figs 8-11.

1972 Carniodus carnus; Rexroad \& Nicoll, pl. 1, figs $12,13$.

1972 Neoprioniodus subcarnus; Rexroad \& Nicoll, pl. 2, figs 6,7 .

v1972 Carniodus carinthiacus; Aldridge, p. 168, pl. 5, figs 8-10.

v1972 Carniodus carnicus; Aldridge, p. 168, pl. 5, fig. 11 .

v1972 Carniodus carnulus; Aldridge, p. 169, pl. 5, figs $12-14$.

v1972 Exochognathus latialatus; Aldridge, p. 179, pl. 7, figs 10,11 .

v1972 Carniodus carnus; Aldridge, p. 169, pl. 5 , figs 15,16 .

v1972 Neoprioniodus subcarnus; Aldridge, p. 195, pl. 5, fig. 17 . 
1975 Carniodus carinthiacus; Saladžius, pl. 1, figs 5a-b.

1975 Neoprioniodus subcarnus; Saladžius, pl. 1, figs $11 \mathrm{a}-\mathrm{b}$.

1975 Neoprioniodus triangularis triangularis; Saladzius, pl. 1, figs $13 \mathrm{a}-\mathrm{b}$.

1975 Carniodus carnulus; Aldridge, pl. 1, figs 3, 4, 8, 9.

1976 Carniodus carnulus; Barrick \& Klapper, p. 68, pl. 1, figs $1,2,6-8,12-14$.

1977 Carniodus carinthiacus; Liebe \& Rexroad, pl. 1, fig. 12 .

1977 Carniodus carnulus; Liebe \& Rexroad, pl. 1, fig. 3 .

1977 Carniodus carnicus; Liebe \& Rexroad, pl. 1, fig. 4 .

1977 Neoprioniodus subcarnus; Liebe \& Rexroad, pl. 1, fig. 1 .

1977 Exochognathus latialatus; Liebe \& Rexroad, pl. 1, fig. 16.

1977 Carniodus carnulus; Viira, p. 181, text fig. 1.

1977 Neoprioniodus subcarnus; Viira, pl. 181, text fig. 1 .

1977? Carniodus carinthiacus; Viira, p. 181, text fig. 1.

1977 Carniodus carnus; Viira, p. 181, text fig. 1.

1978 Apparatus 'D'; Miller, pl. 1, figs 14-17.

1980 Carniodus carnulus; Helfrich, pl. 1, figs 1-6.

1981 Carniodus carnulus; Nowlan, pl. 7, figs 8-11.

1981 Carniodus carnulus; Uyeno \& Barnes, pl. 1, figs $18,19$.

1982 Carniodus carnulus; Aldridge \& Mohamed, pl. 2, figs $17-24$.

1983 Carniodus carnulus; Uyeno \& Barnes, p. 16, pl. 5, figs 1-9.

v1983 Carniodus carnulus; Mabillard \& Aldridge, pl. 2, figs 13,14 .

v1985 Carniodus carnulus; Aldridge, p. 84, pl. 3.2, figs 10-18.

1985 Carniodus carnulus; Savage, p. 714, figs 2A-N

1986 Carniodus carnulus; Bischoff, p. 177, pl. 5, figs $18-34$; pl. 6 , figs $1-37$.

1987 Carniodus carnulus; Over \& Chatterton, pl. 6, figs 28-30.

Holotype. Carniodus carnulus Walliser, 1964, p. 32, pl. 27, fig. 31. From sample C.12A, P. amorphognathoides Biozone of Cellon Mountain, Austria.

Diagnosis. Refer to the generic diagnosis.

Description. Carinthiaciform element. Previously described as $C$. carinthiacus (refer to Aldridge, 1972, p. 168). Morphological variation in the size of the apical denticle and the degree of arching produces a range of elements transitional to the carnuliform element in morphology. Rare examples in large collections exhibit a large, posteriorly inclined 'cusp' and a short, innerlateral process (plate 4 , fig. 19). This form displays a similar morphology to the $\mathrm{Pb}$ element of Pterospathodus amorphognathoides Walliser. Carnuliform element. Previously described as $C$. carnulus (refer to Aldridge, 1972, p. 169). Rare examples of this element possess a short, inner-lateral projection at the base of or below the posterior edge of the cusp. Increased posterior inclination of the cusp and reduction in the number of denticles on the anterior processes result in a transition to the neoprioniodon element morphology; intermediates between the carnuliform and specimens of the neoprioniodontan element are present in large collections.

Neoprioniodontan element. Dolabrate element dominated by a large, laterally compressed, posteriorly inclined cusp, with sharp anterior and posterior edges. The short posterior process bears up to four completely fused denticles, which decrease in size distally. In rare specimens one or two small denticles may be situated on a short inner-lateral process (plate 8, fig. 3). A slightly thickened ledge is present beneath the denticle row around the whole element. The basal cavity is shallowly excavated and expanded laterally beneath the cusp, and extends as a narrow tapering groove to the tip of the posterior process. In lateral view, white matter completely fills the denticles and cusp; its base is coincident with the top of the thickened lateral ledges.

Latialatiform element. The Greenland specimens of this element are identical to those described as $E x$ ochognathus latialatus (Walliser) by Aldridge (1972, p. 179).

An asymmetrical latialatiform element, rarely present in the Greenland and Welsh Borderland collections, differs from the symmetrical latialatiform element in having a shorter inner-lateral process.

Carniform element. Specimens are identical to those described as C. carnus Walliser by Aldridge (1972, p. 169).

Subcarniform element. Previously described as $\mathrm{Ne}$ oprioniodus subcarnus (refer to Aldridge, 1972, p. 195). In rare specimens the distal third of the posterior process appears to be differentiated into the morphology of a carnuliform element (plate 8, fig. 2).

Remarks. On the basis of Greenland material and large collections of the species from the Welsh Borderland housed in the micropalaeontological collection at the University of Nottingham, the apparatus structure appears to be considerably more complicated than that proposed by Barrick \& Klapper (1976). The Pa (carinthiaciform), M (neoprioniodontan), Sa (latialatiform) and Sc (subcarniform) elements can be readily homologised. Several lines of circumstantial evidence suggest that some specimens described as the carnuliform element may represent the Sb element. Specimens (e.g. plate 4 , fig. 27) have on their inner or posterior side, a short, lateral thickening beneath the cusp, a prominent cusp and asymmetrically distributed denticles on the processes. Also rare specimens of the latialatiform and subcarniform elements occur, for example those illustrated by Walliser $(1964$, p. 5 , pl. 28 , figs 15,17$)$ and herein (plate 8 , fig. 2 ), in which one of the processes 
appears to be distally differentiated into a carnuliform element. These specimens may represent partially fused, juxtaposed elements within the apparatus, or 'mutant' specimens from an apparatus in which the $\mathrm{Sb}$ and $\mathrm{Sc}$ elements have not been fully separated during ontogeny. It is also interesting to note that in large collections the carnuliform element is by far the most common numerically (e.g. GGU 82687 contains 20 carinthiaciform and 69 carnuliform elements) and therefore the carnuliform element may have occupied more than one position in the apparatus or existed as multiple pairs within a single apparatus. If the carnuliform element is equivalent to an Sb element, possible candidates for the $\mathrm{Pb}$ element include examples of the carinthiaciform element, particularly the specimens with a prominent cusp (plate 4, fig. 16-18). These also occasionally develop a short inner-lateral process (plate 4, fig. 19) and approach the morphology of a Pterospathodus $\mathrm{Pb}$ element. Carnuliform elements (e.g. plate 4, fig. 20) might also be homologised as the $\mathrm{Pb}$ element. The element previously referred to $C$. carnicus is difficult to homologise; it is not found in the Greenland collection and occurs only rarely in the Welsh Borderland; it may be a mutation of the carnuliform element, or, as suspected from its scaphate basal cavity, may not be a $C$. carnulus element.

Within large collections of $C$. carnulus rare elements assignable to the categories described develop an additional, short, denticulate, inner-lateral process (plate 8 , figs 3,4$)$. These specimens are most commonly of the carnuliform to neoprioniodontan transitional morphology and may be the expression of a recessive character found only in large populations; otherwise, they may be gerontic individuals or extreme members of the symmetry transition series of specimens displaying dimorphic characteristics. In all but the first category they would be expected to occur much more commonly than they do.

Carniodus, as percieved herein has a modified Type IVa apparatus plan (Barnes et al. , 1979); the relationships between, and the homologies of, the elements, particularly in the first transition series, are complex. Occurrence. Found abundantly in Pterospathodus celloni and P. amorphognathoides Biozone strata throughout Greenland.

\section{Genus Dapsilodus Cooper, 1976}

Type species. Distacodus obliquicostatus Branson \& Mehl, 1933a, p. 41.

Emended diagnosis. Apparatus trimembrate comprising laterally compressed elements. The sym. p element with straight upper and lower edges, the former extended laterally by two low costae. The sq element possesses a central costa on each lateral face, the acostate $r$ element has a longer cusp than base.

\section{Dapsilodus obliquicostatus (Branson \& Mehl, 1933a)}

Plate 7, figs 7-12

*1933 Distacodus obliquicostatus, p. 41, pl. 3, fig. 2

1962 Acodus inornatus; Ethington \& Furnish, p. 1259

1962 Distacodus procerus; Ethington \& Furnish, p. 1265 .

?1966 Distacodus procerus; Clark \& Ethington, p. 678, pl. 82 , fig. 4 .

v1969 Distacodus obliquicostatus; Nicoll \& Rexroad, p. 31 , pl. 7 , figs $1-4$.

v1969 Distacodus? n. sp. Nicoll \& Rexroad, p. 32, pl. 7, figs 5-7.

v1969 Acodus cf. A. inornatus; Nicoll \& Rexroad, p. 23 , pl. 7 , figs $8-10$.

?1970 Acontiodus obliquicostatus; Serpagli, p. 82, pl. 23 , figs $1-10$, pl. 24 , figs $1-6$.

1971 Acodus inornatus; Rexroad \& Craig, p. 687, pl. 81 , figs $11-15$.

1971 Distacodus obliquicostatus; Rexroad \& Craig, p. 688 , pl. 81 , figs $5-10$.

1971 Distacodus posterocostatus Rexroad \& Craig, p. 689 , pl. 82, figs 1-4.

v1972 Distacodus obliquicostatus; Aldridge, p. 171 pl. 9, fig. 4.

1972 Distacodus obliquicostatus; Miller, p. 359, pl. 1, fig. 5 .

?1972 Distacodus procerus; Link \& Druce, p. 32, pl. 2, figs $26-29$.

?1974c Acontiodus obliquicostatus; Drygant, pl. 1, figs 32,33 .

1976 Dapsilodus obliquicostatus; Cooper, p. 211, pl. 2, figs $10-13,18-20$.

1977 Dapsilodus obliquicostatus; Barrick, p. 50, pl. 2, figs $6,10,13$.

1977 Distacodus obliquicostatus; Liebe \& Rexroad, pl. 2 , fig. 10,11 .

1977 Distacodus posterocostatus; Liebe \& Rexroad, pl. 2, fig. 12 .

1977 Acodus inornatus; Liebe \& Rexroad, pl. 2, fig. 13 .

1978 Distacodus obliquicostatus; Rexroad, Noland \& Pollock, p. 4, pl. 1, fig. 9.

1981 Dapsilodus obliquicostatus; Aldridge, Dorning \& Siveter, pl. 2, figs 3-5.

1983 Dapsilodus obliquicostatus; Uyeno \& Barnes, p. 16, pl. 9, figs 11,12 .

1983 Dapsilodus obliquicostatus; Wang \& Ziegler, fig. 3 , no. 8 .

1987 Dapsilodus obliquicostatus; Over \& Chatterton, pl. 6, figs 1-2.

Holotype. Distacodus obliquicostatus Branson \& Mehl 1933a, p. 41, pl. 3, fig. 2. From the Bainbridge Formation (middle Silurian), Lithium, Missouri.

Diagnosis. Refer to generic diagnosis. 
Description. Sym. p element: Refer to the description of the symmetrical distacodiform element of $D$. obliquicostatus in Cooper (1976, p. 211).

$s q$ element. Refer to the description of the asymmetrical distacodiform element of $D$. obliquicostatus in Cooper (1976, p. 211).

$r$ element. Refer to the description of the acodontiform element of D. obliquicostatus in Cooper (1976, p. 211).

Remarks. Serpagli (1970) reconstructed the apparatus of Acontiodus obliquicostatus as bimembrate consisting of elements herein designated sq and r. Cooper (1976) transferred the species to a new genus Dapsilodus and described an additional element (sym. p). The apparatus of the type species of Acodus, Acontiodus and Distacodus (the genera under which the elements of Dapsilodus have been previously described) are unknown (Löfgren, 1978, pp. 43-46) and their relationship to Dapsilodus cannot be demonstrated. Barrick (1977, p. 50) emended the diagnosis of Dapsilodus applying the nomenclatural terminology of Sweet \& Schönlaub (1975) to the elements. He recognised M (equivalent to the $r$ element herein), Sa (equivalent to the sym. $p$ element) and $\mathrm{Sb}$ and $\mathrm{Sc}$ elements, separated by the degree of twisting. It appears from his descriptions that this character is found only in $D$. praecipuus Barrick and $D$. sparsus Barrick, but he did not illustrate these as separate elements.

Occurrence. Found in strata from lower-middle Llandovery to upper Llandovery in age, from central Peary Land to Washington Land. Outside Greenland Cooper (1976) recorded the range of this species as lower Silurian to lower Devonian in Europe, North America, North Africa and Australia.

This species occurs in large numbers in samples from Kap Schuchert (Washington Land, fig. 21). Mabillard \& Aldridge (1985, p. 95) also noted the rapid increase in abundance of $D$. obliquicostatus in offshore environments.

\section{Genus Decoriconus Cooper, 1975}

Type species. Paltodus costulatus Rexroad, 1967, p. 40.

Diagnosis. Refer to Cooper (1976, p. 212).

Remarks. The apparatus structure of Decoriconus appears to comprise a transition series from the sym. $p$ to sq elements with a distinctive $r$ element. This suggests a relationship between this genus and Drepanoistodus
Lindström. If the trimembrate apparatus structure of Decoriconus costulatus proposed by McCracken \& Barnes (1981, p. 75, pl. 2, figs 24-27) can be confirmed it is likely that Decoriconus diverged from a Drepanoistodus stock during the Upper Ordovician.

Decoriconus fragilis Branson \& Mehl, 1933a

Plate 7, figs 13-17

${ }^{*} 1933$ Paltodus fragilis, p. 43, pl. 3, fig. 3 .

v1969 Drepanodus aduncus; Nicoll \& Rexroad, p. 35, pl. 7, figs $11-15$.

v1969 Paltodus costulatus; Nicoll \& Rexroad, p. 51, pl. 7, figs 16-18.

?1970 Paltodus costulatus; Pollock, Rexroad \& Nicoll, p. 757 , pl. 114 , figs 29,30 .

1971 Drepanodus aduncus; Rexroad \& Craig, p. 690, pl. 79, figs 11-14.

1971 Paltodus fragilis; Rexroad \& Craig, p. 694, pl. 79, figs 8, 9, 15-17.

v1972 Drepanodus aduncus; Aldridge, p. 175, pl. 9, fig. 7.

v1972 Paltodus costulatus; Aldridge, p. 202, pl. 9, fig. 21 .

1972 Drepanodus aduncus; Miller, p. 559, pl. 1, figs 8, 9. 1972 Paltodus costulatus; Miller, p. 562, pl. 1, fig. 6,

1972 Drepanodus aduncus; Rexroad \& Nicoll, pl. 2, figs $36-37$.

1972 Paltodus fragilis; Rexroad \& Nicoll, pl. 1, fig. 42-43.

1977 Decoriconus fragilis; Barrick, p. 53, pl. 2, figs 15, 21-23.

1978 Decoriconus? fragilis; Rexroad, Noland \& Pollock, p. 4, pl. 1, fig. 10.

1987 Decoriconus fragilis; Over \& Chatterton, pl. 6, fig. 3 .

Holotype. Paltodus fragilis Branson \& Mehl, 1933a, p. 43 , pl. 3, fig. 6. From the Bainbridge Formation (middle Silurian), Lithium, Missouri.

Emended diagnosis. Trimembrate apparatus comprising small, twisted laterally striate cones with a short base and long cusp. The diagnostic $r$ element has a broad straight basal margin and a steeply proclined cusp; it is triangular when viewed laterally.

Description. Complete symmetry transition occurs between the symp. p element (previously described as Paltodus costulatus Rexroad, 1967) and the sq element (previously described as Paltodus fragilis Branson \& Mehl, 1933a). The end members of this transition differ only in the degree of curvature of the cusp. $r$ element. Previously described as Drepanodus aduncus Nicoll \& Rexroad (1969). A range in morphology of this element is illustrated by the Greenland collections, from the laterally compressed more or less symmetrical element (plate 7, figs 15-16) to the twisted asymmetrical ele- 
ments described by Cooper (1976, p. 213, pl. 2, figs 5-8).

Remarks. Cooper (1976, p. 212) proposed the original apparatus reconstruction of $D$. fragilis which was subsequently confirmed by Barrick (1977, p. 53). The apparatus of Decoriconus differs from that of Dapsilodus in that the sym. p and aq elements are morphologically transitional, a feature more typical of Drepanoistodus. D. fragilis lacks an aq element and, if descended from a Drepanoistodus stock, must have lost this element. A similar evolutionary development may also have occurred in Belodella.

Occurrence. Abundant in the Washington Land Group at Kap Schuchert in association with Aspelundia fluegeli and Dapsilodus obliquicostatus. Outside Greenland this species has been recorded in rocks of $P$. celloni Biozone to Upper Silurian in age (Cooper, 1980, p. 213).

\section{Genus Dentacodina Wang, 1980}

1980 Dentacodina Wang, p. 370.

Type species. Dentacodina multidentata Wang, 1980, p. 370.

Remarks. All the elements except the Pa can be homologised with those of Distomodus (Branson \& Branson) sensu Barrick \& Klapper (1976). The structure of several elements, particularly the $\mathrm{Pa}$ and $\mathrm{S}$ elements, suggests their denticles may have formed separately from the main element, later fusing to the base of the cusp (Jeppsson, 1972, p. 57). Intermediate forms in this process may be those illustrated by Walliser (1964, pl. 10, figs 1-7, 10-12 and pl. 1, figs 2, 7-13).

Dentacodina aff. D. dubia (Rhodes, 1953) Plate 20, figs 17-22

aff. 1953 Cordylodus? dubius Rhodes, p. 299, pl. 23, figs 221-224.

Description. Pa element. A single broad-based cone, antero-posteriorly compressed, oval in midheight cross section. The base flares broadly to the anterior and posterior and slightly laterally; the entire lower surface is deeply excavated.

$\mathrm{Pb}$ element. Modified coniform element comprising a long, slightly compressed, highly reclined and inwardly bowed cusp. Its base is broadly flared to form a heartshaped platform, which is broadest posteriorly and nar- rows to a point anteriorly. Inwardly, between the cusp and the anterior edge of the platform, the margin is sharply indented. The anterior edge of the cusp possesses a weakly developed costa which increases in height anteriorly, extending to the anterior edge of the platform. The entire lower surface appears to be shallowly excavated, obscured in all specimens by mineral infill.

$M$ element. Laterally compressed, fused group of three coniform elements. These are subequal in size, posteriorly recurved and oval in cross section. The most anterior of the cones is erect, the others are posteriorly inclined. In lateral view the lower edge of the element is strongly arched upwards, the apex lying beneath the posterior edge of the anterior denticle. Commonly a broad zone of basal material occurs beneath the element, its lower edge close to that of the element; the basal material is deeply excavated.

Sa element. Alate element, dominated by a broad, squat cusp which is circular in cross section. Posteriorly and centrally, a single, short denticle projects from just above its base. Antero-laterally the two symmetrically disposed processes consist of two fused, coniform denticles, these also have a circular cross section; are inclined postero-laterally and have a broad base which tapers gradually upwards. The most proximal denticle of each process is fused to the cusp only by its base. The entire lower surface is deeply excavated.

$S b$ element. Laterally compressed element, again dominated by a squat, circular cross sectioned cusp. This is gently curved towards the posterior. Basally the cusp is expanded posteriorly but lacks the posterior denticle of the Sa element. Laterally the cusp bears one or two separate coniform denticles fused at the edge. Those on the inner face are situated slightly more postero-laterally when compared with those on the outer face of the cusp. The lowest denticle on each side is usually the largest, two to three times the size of the other denticles. The lower surface is infilled with basal material in all specimens.

Sc element. Long, posteriorly recurved cusp with a laterally compressed, broad base; the upper two-thirds of the cusp are almost horizontally directed. Two coniform denticles are fused, one to the posterior basal corner and the other centrally to the inner-lateral edge of the cusp. These are small, circular in cross section and upwardly curved, the posterior denticle is more or less horizontally directed, the inner-lateral denticle lies parallel though separate from the anterior edge of the cusp; the posterior denticle is usually the smaller of the two. The lower surface of this element is infilled with a broad zone of basal material. The white matter distribution in all the elements is very similar. The cusp and 
denticles are completely filled with dense white matter, which does not extend into the basal section of any of the elements. Each coniform denticle has a separate basal cavity tip which is marked by the basal outline of the white matter.

Remarks. Elements referred to this species consist characteristically of fused coniform elements, all have similar white matter distribution and basal cavity style. Distomodus dubius Jeppsson differs from the Greenland specimens in the style of the denticulation: each denticle is an integral part of an element and does not appear to be superficially fused to it. The cusps of the elements of $D$. dubius are laterally costate, a feature not developed in their counterparts in $R$. aff. $R$. dubia. $R$. aff. $R$. dubia Rhodes of Mabillard \& Aldridge (1983) has a similar apparatus structure, but differs in containing strongly, laterally compressed elements.

If the specimens discussed prove to be part of the same genus, then the lineage appears to have ranged from Llandovery to at least early Gedinnian. Jeppsson (1972) noted the abundance of similar elements in shallow water faunas from Ludlow strata of Scania.

Occurrence. Found infrequently in Pterospathodus celloni Biozone strata.

\section{Genus Distomodus Branson \& Branson, 1947}

1947 Distomodus, p. 553.

1964 Hadrognathus Walliser, p. 35.

1970 Exochognathus Pollock, Rexroad \& Nicoll, p. 751.

1977 Johnognathus Mashkova, p. 127.

Type species. Distomodus kentuckyensis Branson \& Branson, 1947.

Diagnosis. Refer to Bischoff, 1986, p. 94.

Remarks. Johnognathus $\mathrm{Pa}$ elements represent broken processes of D. staurognathoides $\mathrm{Pa}$ and Sa elements (Over \& Chatterton, 1987, pl. 2, figs 13-16, 21-25), Savage (1985, fig. 9A) figured a similar specimen which helps substantiate this conclusion.

Distomodus staurognathoides (Walliser, 1964)

Plate 8, figs 6-10; pl. 9, figs 2-3.

$\mathrm{v}^{*} 1964$ Hadrognathus staurognathoides, p. 35, pl. 5, fig. 2 ; pl. 13 , figs $6-15$.

v1964 Roundya caudata Walliser, p. 70, pl. 5, fig. 9; pl. 31 , figs $18,19$.

v1964 Roundya detorta Walliser, p. 70, pl. 5, fig. 8; pl. 31, figs 15-17. v1964 Ligonodina egregia Walliser, p. 40, pl. 6, fig. 5; pl. 32 , figs 3,4 .

1965 Hadrognathus staurognathoides; Brooks \& Druce, p. 376 , pl. 2 , figs 5,6 .

v1969 Hadrognathus staurognathoides; Nicoll \& Rexroad, p. 36, pl. 3, figs 12-14.

v1969 Trichonodella? expansa Nicoll \& Rexroad, p. 67, pl. 4, figs 19-22.

v1969 Distomodus kentuckyensis; Nicoll \& Rexroad, p. 34 , pl. 5 , figs 24,25 .

v1969 Roundya detorta; Nicoll \& Rexroad, p. 58, pl. 6, figs $16-18$.

v1969 Distomodus? egregia; Nicoll \& Rexroad, p. 33, pl. 5, figs 26-28.

v1969 Distomodus? extrorsus; Nicoll \& Rexroad, p. 34, pl. 5 , fig. 23 .

1970 Hadrognathus staurognathoides; Moskalenko, pl. 1 , fig. 8 .

1970 Ligonodina cf. egregia; Moskalenko, pl. 1, fig. 2.

1971 Hadrognathus staurognathoides; Schönlaub, p. 44, pl. 1, figs 17,18 .

1971 Ambalodus carnicus Schönlaub, p. 45, pl. 2, figs 18-20.

1971 Distomodus kentuckyensis; Schönlaub, p. 47, pl. 3, fig. 9.

1971 Hibbardella caudata; Schönlaub, p. 47, pl. 3, figs 12,13 .

1971 Hibbardella brevialata; Schönlaub, p. 47, pl. 3, figs 10,11 .

?1972 Hadrognathus staurognathoides; Rexroad \& Nicoll, pl. 2, fig. 45 .

?1972 Exochognathus expansus; Rexroad \& Nicoll, pl. 2, figs 24,25 .

?1972 Distomodus kentuckyensis; Rexroad \& Nicoll, pl. 2, fig. 46.

?1972 Exochognathus brassfieldensis; Rexroad \& Nicoll, pl. 2, fig. 23.

?1972 Exochognathus caudatus; Rexroad \& Nicoll, pl. 1 , fig. 14

?1972 Distomodus egregia; Rexroad \& Nicoll, pl. 2, figs 47,48 .

? 1972 Distomodus extrorsus; Rexroad \& Nicoll, pl. 2, figs 49,50 .

v1972 Hadrognathus staurognathoides; Aldridge, p. 180 , pl. 2, figs $8,10,11$.

v1972 Trichonodella? expansa; Aldridge, p. 218, pl. 7, figs $14 \mathrm{a}, 14 \mathrm{~b}, 14 \mathrm{c}$.

v1972 Distomodus kentuckyensis; Aldridge, p. 173, pl. 6, figs 5-8, 11 .

pv1972 Exochognathus detortus; Aldridge, p. 178, pl. 7, fig. 12 , spec. X.672 only.

v1972 Exochognathus caudatus; Aldridge, p. 172, pl. 6, fig. 13.

v1972 Distomodus? egregius; Aldridge, p. 172, pl. 6, figs $3,4,9$.

v1975 Hadrognathus staurognathoides; Aldridge, pl. 3, fig. 18.

1975 Hadrognathus staurognathoides; Klapper \& Murphy, p. 27, pl.2, figs 21-25.

1975b Hadrognathus staurognathoides; Schönlaub, p. 53, pl. 1 , figs $1-4,17,20,23-25$; pl. 2 , figs $1-10$, 12-21.

1976 Distomodus staurognathoides; Barrick \& Klapper, p. 71 , pl. 1 , figs $20-28$.

1977 Hadrognathus staurognathoides; Liebe \& Rexroad, pl. 1, fig. 36.

1977 Exochognathus expansus; Liebe \& Rexroad, pl. 1 , fig. 28.

1977 Distomodus kentuckyensis; Liebe \& Rexroad, pl. 1 , fig. 30 .

1977 Exochognathus caudatus; Liebe \& Rexroad, pl. 1, figs 32,33 . 
1977 Exochognathus brassfieldensis; Liebe \& Rexroad, pl. 1 , fig. 34 .

1977 Exochognathus detortus; Liebe \& Rexroad, pl. 1, fig. 39.

1977 Distomodus extrorsus; Liebe \& Rexroad, pl. 1, fig. 31 .

1977 Distomodus egregia; Liebe \& Rexroad, pl. 1, figs 37,38 .

1977a Hadrognathus staurognathoides; Cooper, p. 1066, pl. 1, figs $5,6,7,12,16$.

1977 Johnognathus huddlei Mashkova, p. 129-131, figs $2 \mathrm{a}-\mathrm{g}$ (Pa element only).

1978 Hadrognathus staurognathoides; Miller, pl. 4, fig. 26.

1979 Distomodus staurognathoides; Aldridge, pl. 1, figs $16-17$

1981 Distomodus staurognathoides; Nowlan, pl. 5, figs 21,27 ; pl. 6 , fig. 21 .

1981 Distomodus staurognathoides; Uyeno \& Barnes, pl. 3, fig. 1-5.

1981 Johnognathus huddlei; Uyeno \& Barnes, pl. 1, fig. 25 .

1982 Distomodus staurognathoides; Aldridge \& Mohamed, pl. 2, figs 1-6.

1982 Johnognathus huddlei; Aldridge \& Mohamed, pl. 2 , fig. 25 .

?p1983 Distomodus staurognathoides; Nowlan, figs ?4F, $4 \mathrm{G}, 4 \mathrm{H}$.

1983 Johnognathus huddlei; Mabillard \& Aldridge, pl. 2, figs 11-12.

v1983 Distomodus staurognathoides; Mabillard \& Aldridge, pl. 1, figs 15-20.

1983 ?Johnognathus huddlei; Uyeno \& Barnes, pl. 1, fig. 25 .

v1985 Distomodus staurognathoides; Aldridge, p. 80, pl. 3.1, figs 12-17.

1985 Distomodus staurognathoides; Savage, p. 718, figs 9A-L.

1985 Johnognathus huddlei; Savage, p. 716, figs 6A-K, 7.

1986 Johnognathus huddlei; Bischoff, p. 227, pl. 12, figs $29-40$; pl. 13, figs $1-7$.

1986 Distomodus staurognathoides; Bischoff, p. 106, pl. 10 , figs $13-36$; pl. 11 , figs $1-33$; pl. 12 , figs 1-28.

1987 Distomodus staurognathoides; Over \& Chatterton, pl. 2, figs $10-25$.
Holotype. Hadrognathus staurognathoides Walliser, 1964, p. 35, pl. 5, fig. 2; pl. 13, fig. 7. From sample 11c within the P. celloni Biozone of the Carnic Alps, Austria.

Diagnosis. Refer to that in Bischoff (1986, p. 227).

Description. Pa element. Identical to the specimens referred to $H$. staurognathoides Walliser by Aldridge (1972, p. 180). White matter is concentrated into the high ornament of the upper surface.

$\mathrm{Pb}$ element. Highly arched, stelliscaphate element, comprising a large, basally expanded cusp, short denticulate anterior and posterior processes and adenticulate inner process. The cusp is laterally compressed; has well developed costae along its anterior and posterior edges and centrally down the lateral faces. The base of the cusp is differentially expanded on its inner-lateral side. The anterior process extends antero-basally, and slightly inwards, it bears one or two denticles. The posterior process is tall, extending from the base of the cusp and bearing two partially fused, compressed denticles. A short, adenticulate postero-laterally directed process extends from the inner base of the cusp. White matter fills the cusp and denticles, the base forming a linear trace just below the base of the denticles.

$M$ element. The Greenland specimens are similar in overall morphology to those described as Distomodus kentuckyensis Branson \& Branson by Aldridge (1972, p. 173). They develop slightly more convex lateral faces, are more erect and have a more steeply denticulate outer-lateral process. White matter fills the main body of the cusp and its lateral eostae.

?Sa element. Only cusp fragments of this element are present in association with the $\mathrm{Pa}$ element. These bear

\section{Plate 8}

Figs 1-4. Carniodus carnulus Walliser. All specimens from GGU 216853.

1, microstriations on inner-lateral face of subcarniform element, $\times$ 215; MGUH 17.724.

2 , inner-lateral view of subcarniform element, $\times 60$; MGUH 17.724 .

3 , inner-lateral view of element, $\times 60$; MGUH 17.725 .

4 , inner-lateral view of element, $\times 60$; MGUH 17.726 .

Fig. 5. Carniodus sp.

From GGU 184125.

5 , inner-lateral view of element, $\times 60 ;$ MGUH 17.727 .
Figs 6-10. Distomodus staurognathoides (Walliser).

All specimens from GGU 216773, unless otherwise stated.

6, upper view of Pa element, $\times 60$; MGUH 17.728 .

7, inner-lateral view of M element, $\times 60$; MGUH 17.729 from GGU 184125

8 , posterior view of Sb element, $\times 60$; MGUH 17.730 .

9, posterior view of Sa element, $\times$ 40; MGUH 17.731.

10 , inner-lateral view of Sc element, $\times 40$; MGUH 17.732 .

Figs 11-16. Distomodus n. sp.

All specimens from GGU 216837.

11, upper view of Pa element, $\times 40 ;$ MGUH 17.733

12 , inner-lateral view of $\mathrm{Pb}$ element, $\times 60$; MGUH 17.734

13 , inner-lateral view of $\mathrm{M}$ element, $\times 40 ;$ MGUH 17.735 .

14, inner-lateral view of Sc element, $\times 40$; MGUH 17.736 .

15 , posterior view of Sa element; $\times 40$; MGUH 17.737 .

16, posterior view of Sb element, $\times 40 ;$ MGUH 17.738 . 


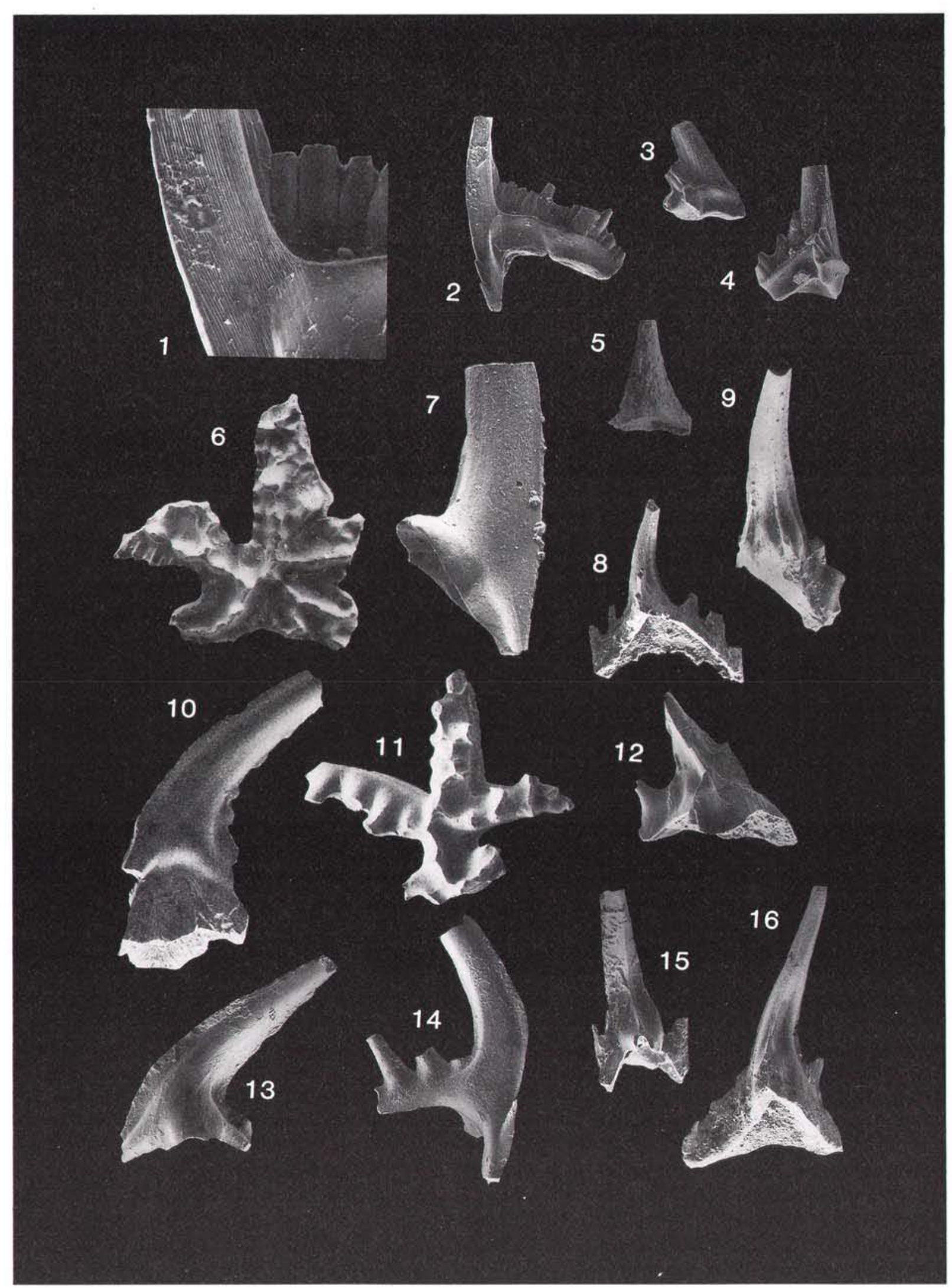


the remains of two symmetrically disposed lateral processes and a posterior process. The cusp is rounded in cross section and bears tall costae which are situated centrally on the lateral faces and posteriorly. The basal cavity is deeply excavated extending as a narrow groove along the processes.

Sb element. Previously described as Exochognathus caudatus (Walliser). Refer to Aldridge (1972, p. 177178).

Sc element. Previously described as Exochognathus brassfieldensis (Branson \& Branson); refer to Aldridge (1972, p. 176-177).

Remarks. The $\mathrm{Pb}$ element described from Greenland differs from that recognised by Barrick \& Klapper (1976) in lacking a broad, denticulate, posterior process. Barrick \& Klapper (1976, p. 71) noted that the development of lateral platform ledges on the posterior process occurs in large robust specimens, and that the morphology exhibited by the Greenland specimens may fall within the range of ontogenetic variation of the $\mathrm{Pb}$ element. Where no diagnostic $\mathrm{Pa}$ is present in the Greenland samples, elements attributable to Distomodus are recorded under Distomodus spp.

Occurrence. Rare in upper Aeronian $\left(\mathrm{C}_{3}-\mathrm{C}_{5}\right.$ of Jones, 1925) strata throughout North Greenland.

Distomodus n. sp.

Plate 8, figs 11-16

Description. Pa element. Cruciform, stelliscaphate element with narrow processes, the posterior is the shorter of the four. This element is rarely complete, due to the fragile nature of its walls. The anterior and posterior processes are longer than the lateral processes and are slightly curved inwards. The lateral processes diverge anteriorly from a point just posterior of the midlength; they form a variable angle of $45^{\circ}-90^{\circ}$ to the anterior process. Rare specimens occur in which one of the lateral processes diverges at a slightly different angle from the other. The upper surface of all the processes, bears irregular, discrete nodes; larger specimens have a mixed ornament of coalescing nodes, sinuous transverse ridges and discrete denticles. The entire lower surface is deeply excavated, the basal cavity being deeper beneath the junction of the processes. White matter is restricted to the areas of raised ornament on the upper surface.

$\mathrm{Pb}$ element. Arched, pastiniscaphate element with a long, compressed, posteriorly inclined cusp, short denticulate posterior process and adenticulate anterior and postero-lateral processes. The base of the cusp is lat- erally expanded; its edges bear prominent longitudinal costae, which pass downwards into the denticles. These commonly bear only two compressed, discrete denticles, of which the most proximal is completely fused to the cusp. White matter fills the cusp and denticles; its base forms a linear trace at the midheight of the processes.

M element. Modified dolabrate element, with a prominent posteriorly inclined cusp, short posterior process and short anticusp. The cusp is laterally compressed and has tall costae along its anterior and posterior edges, it is lenticular in midheight cross section. Basally the cusp is inflated inwards and extended posteriorly as a short process which may bear one or two denticles. The antero-basal corner of the cusp is extended downwards to form an adenticulate rudimentary anticusp. The basal cavity is deeply excavated, extending as a groove along the posterior process and anticusp. White matter fills the cusp and posterior process denticles; when these are absent, a thin trace of white matter extends along the upper edge of the posterior process.

Sa element. The Greenland specimens of this element are similar to those referred to Exochognathus caudatus Walliser by Aldridge (1972, p. 177), differing only in having shorter lateral processes, which bear one or two discrete denticles. In large well preserved specimens each denticle has its own separate basal cavity apex. White matter fills the cusp and denticles, its base defines a sharp linear trace, just above the midheight of the processes.

Sb element. Tertiopedate element, dominated by a tall, erect, laterally twisted cusp, which bears tall longitudinal costae, centrally on the lateral and posterior faces. The base of the cusp is laterally and posteriorly expanded. The costae pass downwards into the denticles of the asymmetrically disposed lateral and posterior processes. The posterior process is shorter than the laterals, each of which bears three to four discrete denticles. The basal cavity is deeply excavated beneath the cusp, extending as a tapering groove along the processes. White matter is distributed as in the Sa element.

Sc element. Specimens are similar to those referred to Ligonodina? extrorsa Rexroad (1967) and Distomodus? extrorsus (Rexroad) by Nicoll \& Rexroad (1969) and Aldridge (1972), differing only in possessing a single denticle on the inner-lateral process and commonly three partially fused denticles on the posterior process. White matter distribution is as described for the Sa element. The single inner-lateral denticle is completely filled with white matter.

Remarks. This species is only present in two reconnaissance samples from Washington Land and conforms 
closely to that of $D$. kentuckyensis. Distomodus $\mathrm{n}$. sp. is characterised by the $\mathrm{Pa}$ element, most specimens of which are fragmentary. They bear irregular though discrete nodes and resemble Icriodina stenolaphata Rexroad (1967). Several large, robust specimens are similar to the Pa element of $D$. kentuckyensis. Rare specimens approach Icriodina sp. Aldridge (1972, p. 87, pl. 2, fig. $2)$. This variation may be ontogenetic or represent morphologically distinct $\mathrm{Pa}$ elements within a single apparatus. The $\mathrm{Pb}$ element of Distomodus n. sp. is more closely comparable with that of $D$. staurognathoides than that of $D$. kentuckyensis. Murphy et al. (1979, p. 29 , figs 1,4) illustrated two cruciform Pa elements with only a single row of nodes on the carina, which may represent juvenile $\mathrm{Pa}$ elements of Distomodus n. sp.

Occurrence. Found in samples GGU 216837 and 216838 (fig. 21).

\section{?Distomodus $\mathrm{sp}$.}

Plate 9, fig. 1

Description. ?Pa element. A single specimen, oval in upper outline, slightly broader anteriorly, bears an upper ornament of two transverse ridges, each slightly raised laterally. The entire lower surface is deeply excavated.

Remarks. This may be a juvenile specimen of a Distomodus species.

\section{Genus Kockelella Walliser, 1964}

Type species. Kockelella variabilis Walliser, 1957, p. 35.

Diagnosis. Refer to Barrick \& Klapper (1976, p. 72).

Remarks. The apparatus structure of Kockelella is similar to that of Ozarkodina, but the genus differs in the morphology of the $\mathrm{Pa}$ element and the wide spacing of the denticles on the $\mathrm{Pb}, \mathrm{M}$ and $\mathrm{S}$ elements.

\section{Kockelella manitoulinensis (Pollock, Rexroad \& Nicoll, 1970) \\ Plate 9, figs 4-14}

v*1970 Spathognathodus manitoulinensis, p. 761, pl. 111, figs $17-19$.

1977 Spathognathodus manitoulinensis; Liebe \& Rexroad, pl. 1, fig. 26.

1981 Spathognathodus manitoulinensis; McCracken \& Barnes, p. 90, pl. 7, fig. 19.
Holotype. Spagthognathodus manitoulinensis Pollock, Rexroad \& Nicoll, 1970, p. 761, pl. 111, figs 19a, 19c. Sample 5-1, from the Manitoulin Dolomite, Michigan.

Emended diagnosis. A species of Kockelella with a carminiscaphate $(\mathrm{Pa})$ element displaying an inwardly deflected posterior process. All elements except the $\mathrm{Pa}$ element have a small laterally restricted basal cavity and widely spaced, compressed, pointed denticles.

Description. Pa element. Carminiscaphate, with two blade-like processes. The anterior process is straight to slightly sigmoidal and is twice as high as the posterior process. An inconspicuous apical denticle is situated at the junction of the processes. Up to fourteen denticles are present on the anterior process and only five on the posterior; the denticles are small, compressed and triangular in lateral view, in large specimens they are variable in size with those on the posterior process smaller than those on the anterior. The posterior process is inwardly deflected, at an angle of $150^{\circ}-170^{\circ}$ to the anterior process, this angle varies randomly through the stratigraphical range of the species. The basal cavity is laterally flared beneath the apical denticle; the outer lip is usually more strongly developed than the inner lip. In rare, small specimens the basal cavity is hardly flared. In lower view the basal cavity outline is broadly oval, extending on the tips of the processes as a tapering groove. Posteriorly the lower edge of the process is commonly slightly flared, producing a broader groove beneath this process.

$\mathrm{Pb}$ element. Angulate, laterally compressed element. The cusp is tall, compressed and inclined slightly towards the posterior. Anteriorly the process is straight and may be directed downwards forming an angle of up to $160^{\circ}$ with the lower edge of the almost horizontal posterior process. The anterior bears three to four discrete, pointed denticles, the posterior process only two or three smaller denticles. Basally, the shallowly excavated cavity is slightly flared beneath the cusp; it is oval in lower view, extending to the tips of the processes as a narrow, tapering groove.

$M$ element. Dolabrate, with a small, erect, compressed cusp and long posterior process extending downwards from the lower edge of the cusp. The process bears up to five pointed, discrete denticles which are separated by narrow ' $v$-shaped' spaces. Antero-basally the cusp may develop a short, rudimentary, denticulate process. The basal cavity is broadly expanded beneath the inner edge of the cusp, extending to the tip of the posterior process as a narrow, tapering, groove.

Sa element. Alate, the cusp is erect, laterally compressed, oval in midheight cross section, bearing a costa 
on each edge. The lateral processes are equal in length and form an angle of approximately $120^{\circ}$ between their lower edges. Each bears three or four compressed, widely spaced, slender, outwardly inclined denticles. The shallowly excavated basal cavity is posteriorly expanded beneath the cusp, extending as a rapidly tapering groove to the tips of the processes.

Sb element. Tertiopedate, with the posterior process reduced to a slight swelling at the base of the cusp. The cusp is laterally compressed, its edges are costate. The lateral processes form an angle of $110^{\circ}-130^{\circ}$ between their lower edges and are slightly, posteriorly, bowed; the inner is less steeply inclined and shallower than the outer, both bear three or four compressed, peg-like denticles. The posterior tip of the basal cavity is slightly flared, the cavity extending as a narrow groove to the tips of the processes.

Sc element. Bipennate, the anterior process is sharply downturned and only slightly inwardly bowed, its lower edge forming an angle of $110^{\circ}$ with that of the posterior process. The anterior process bears three widely spaced, anteriorly inclined denticles, the most proximal of which is situated close to the cusp. Posteriorly, the process is broken in all specimens, it is only slightly downturned and bears similar denticles to those on the anterior process, they appear to be less widely spaced. The basal cavity is only slightly expanded beneath the cusp and shallowly excavated, extending to the tips of the processes as a narrow groove.

Remarks. The $\mathrm{Pa}$ element is the most commonly recorded. The deflection on the Pa element of the post- erior processes and the denticulation, basal cavity morphology and white matter distribution of the $\mathrm{P}, \mathrm{M}$ and $\mathrm{S}$ elements are almost identical to those in comparable elements of Kockelella ranuliformis (see Barrick \& Klapper, 1976).

Aldridge (1972) described Spathognathodus abruptus and considered it distinct from $S$. manitoulinensis in the angle of deflection of the posterior process, the shorter posterior process and the increased inner-lateral development of the basal cavity. Study of the holotypes of both these species shows them to have closely similar denticulation, white matter distribution and basal cavity style. Topotype collections of $S$. abruptus stored at the University of Nottingham contain rare ramiform elements similar to those of $K$. manitoulinensis, but no $\mathrm{Pb}$ elements. The morphological differences described by Aldridge (1972) between the Pa elements of these two species fall within the range of morphologies displayed by paratype specimens of $K$. manitoulinensis figured by Pollock et al. (1970, pl. 111, figs 17-19). McCracken \& Barnes (1981, p. 90) considered S. abruptus to be a junior synonym of $O$. manitoulinensis, but until the complete $S$. abruptus apparatus is known this synonymy is premature. McCracken \& Barnes (1981, p. 84) also recorded specimens of Ozarkodina oldhamensis with a bowed posterior process and suggested that these were transitional to $K$. manitoulinensis. The morphological differences displayed by the other elements of $O$. oldhamensis suggest this similarity is purely coincidental.

The Pa element of $K$. manitouliensis is closely similar in process orientation, basal cavity morphology and white matter distribution to its counterpart in the appa-

\section{Plate 9}

Fig. 1. ?Distomodus sp.

1, upper view of Pa fragment, $\times 60$; MGUH 17.739 from GGU 216887.

Figs 2, 3. Distomodus staurognathoides (Walliser). Specimens from GGU 275048, × 40 .

2, upper view of Pa lateral process; MGUH 17.740.

3 , inner-lateral view of $\mathrm{Pb}$ element; MGUH 17.741.

Figs 4-14. Kockelella manitoulinensis (Pollock, Rexroad \& Nicoll).

All specimens $\times 60$.

4, inner-lateral view of Pa element; MGUH 17.742 from GGU 256381.

5. inner-lateral view of Pa element; MGUH 17.743 from GGU 256387.

6, inner-lateral view of Pa element; MGUH 17.744 from GGU 228905 .

7, inner-lateral view of Pa element; MGUH 17.745 from GGU 228958 .
8, upper view of Pa element, MGUH 17.746 from GGU 256387.

9, inner-lateral view of Pb element, MGUH 17.747 from GGU 256381.

10 , inner-lateral view of $\mathrm{Pb}$ element; MGUH 17. 748 from GGU 256387.

11, inner-lateral view of M element; MGUH 17.749 from GGU 256381.

12, posterior view of Sa element; MGUH 17.750 from GGU 256387.

13, posterior view of Sb element; MGUH 17.751 from GGU 256387.

14, inner-lateral view of Sc element; MGUH 17.752 from GGU 256387.

Figs 15-19. Kockelella cf. K. ranuliformis (Walliser).

All specimens from GGU 228978, $\times 40$.

15, upper view of Pa element; MGUH 17.753.

16, upper view of Pa element; MGUH 17.754

17, inner-lateral view of $M$ element; MGUH 17.755.

18, posterior view of Sa element; MGUH 17.756.

19, inner-lateral view of $\mathrm{Pb}$ element; MGUH 17.757. 


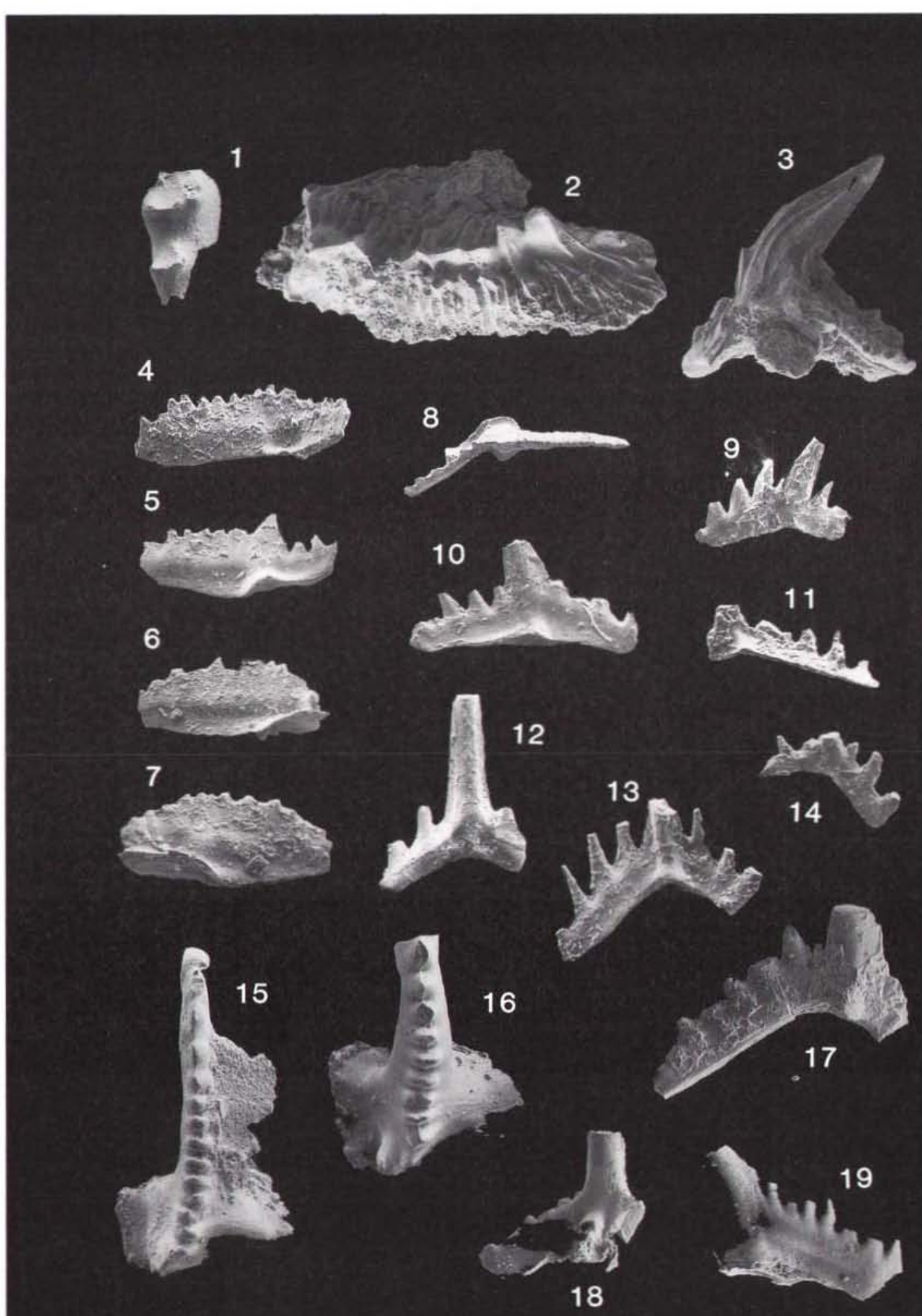


ratus of Ozarkodina? pseudofissilis Lindström, 1959. Orchard (1980, p. 22, pl. 6, figs $26,28,31)$ included an angulate $(\mathrm{Pb})$ element, with completely fused denticles in the apparatus of $O . ?$ pseudofissilis, which seems to distinguish it from $K$. manitoulinensis. The two Pa elements may be homeomorphs.

Occurrence. The lowest record is $25 \mathrm{~m}$ above the last unequivocal Richmondian fauna in the middle part of the Turesø Formation, and the species ranges into the upper part of the Odins Fjord Formation. It occurs abundantly in Peary Land and is commonly the only ramiform apparatus present in samples from the lower Odins Fjord Formation. In Washington Land this species has only been recorded at Bessels Fjord in strata indicative of shallow shelf environments.

Outside Greenland this species has been documented from lowest Silurian to the $P$. amorthognathoides Biozone (Barnes et al., 1978, p. 69).

\section{Kockelella cf. K. ranuliformis (Walliser) Barrick} \& Klapper, 1976

Plate 9, figs 15-19

$\mathrm{v}^{*}$ cf. 1964 Spathognathodus ranuliformis Walliser, p. 82, pl. 6, fig. 9; pl. 22, figs 5-7.

cf. 1976 Kockelella ranuliformis; Barrick \& Klapper, p. 76, pl. 2, figs 1-11.

Description. Pa element. Segminiscaphate, with an inwardly bowed carina and small, posteriorly situated platform. The carina is free for most of its length, bears twelve to fifteen denticles, which in large specimens have a tendency to split centrally (plate 9 , figs 15,16 ); the most posterior denticle situated at the margin of the platform, is slightly inwardly offset. In upper view the platform is quadrate in outline, its outer lateral development forms two-thirds of its width. The upper surface of the platform is steeply inclined downwards, its margin is flat. The entire under surface of the platform is shallowly excavated, the basal cavity extending along the carina as a narrow groove.

The specimens are thermally mature and white matter is not visible. The remaining elements are identical to those figured by Barrick \& Klapper (1976, p. 76, pl. 2, figs 1-11).

Remarks. Kockelella cf. $K$. ranuliformis differs from $K$. ranuliformis in the asymmetrical and posteriorly restricted development of the platform in the Pa element. This character is also shown by $K$. walliseri (Helfrich) (see Barrick \& Klapper, 1976, p. 78, pl. 2, figs 24, 25) which additionally displays an outer, antero-lateral process. The Greenland specimens may represent a variant of $K$. ranuliformis.

Specimens of the Sc element of $K$. cf. $K$. ranuliformis are fragmented and unsuitable for illustration.

Occurrence. Found only in the Wulff Land Formation of central Peary Land and Kronprins Christian Land. Outside Greenland $K$. ranuliformis is recorded from the $P$.

\section{Plate 10}

Fig. 1. Kockelella aff. K. patula Walliser. From GGU 256351.

1, upper view of Pa element, $\times 40$; MGUH 17.758.

Figs 2-5. Oulodus sp. A.

All specimens $\times 40$.

2, inner-lateral view of M element; MGUH 17.759 from GGU 216842.

3. posterior view of Sa element; MGUH 17.760 from GGU 216837.

4, inner-lateral view of Pa element; MGUH 17.761 from GGU 216842.

5, oblique upper-posterior view of Sb element; MGUH 17.762 from GGU 216842.

Figs 6-10. Oulodus sp. B.

All specimens from GGU 274721, × 60 .

6, inner-lateral view of Pa element; MGUH 17.763.

7, inner-lateral view of M element; MGUH 17.764.

8, posterior view of Sa element; MGUH 17.765.

9, posterior view of Sb element; MGUH 17.766.

10, inner-lateral view of Sc element; MGUH 17.767
Figs 11-16. Oulodus sp. A. Aldridge.

All specimens $\times 60$.

11, lower view of $\mathrm{Pb}$ element; MGUH 17.768 from GGU 228970.

12 , inner-lateral view of ?Pa element; MGUH 14.068 from GGU 184125 .

13, posterior view of Sa element; MGUH 14.070 from GGU 184125.

14 , inner-lateral view of M element; MGUH 17.769 from GGU 228970.

15, posterior view of Sb element; MGUH 14071 from GGU 184125.

16, inner-lateral view of Sc element; MGUH 17.770 from GGU 228970.

Fig. 17. Oulodus sp. indet. group 1.

17, inner-lateral view of P element, $\times 40$; MGUH 17.771 from GGU 256375.

Figs 18, 19. Oulodus spp. indet. group 2.

Specimens from GGU 274754, × 60 .

18, posterior view of Sa element; MGUH 17.772.

19. posterior view of Sb element; MGUH 17.773 . 


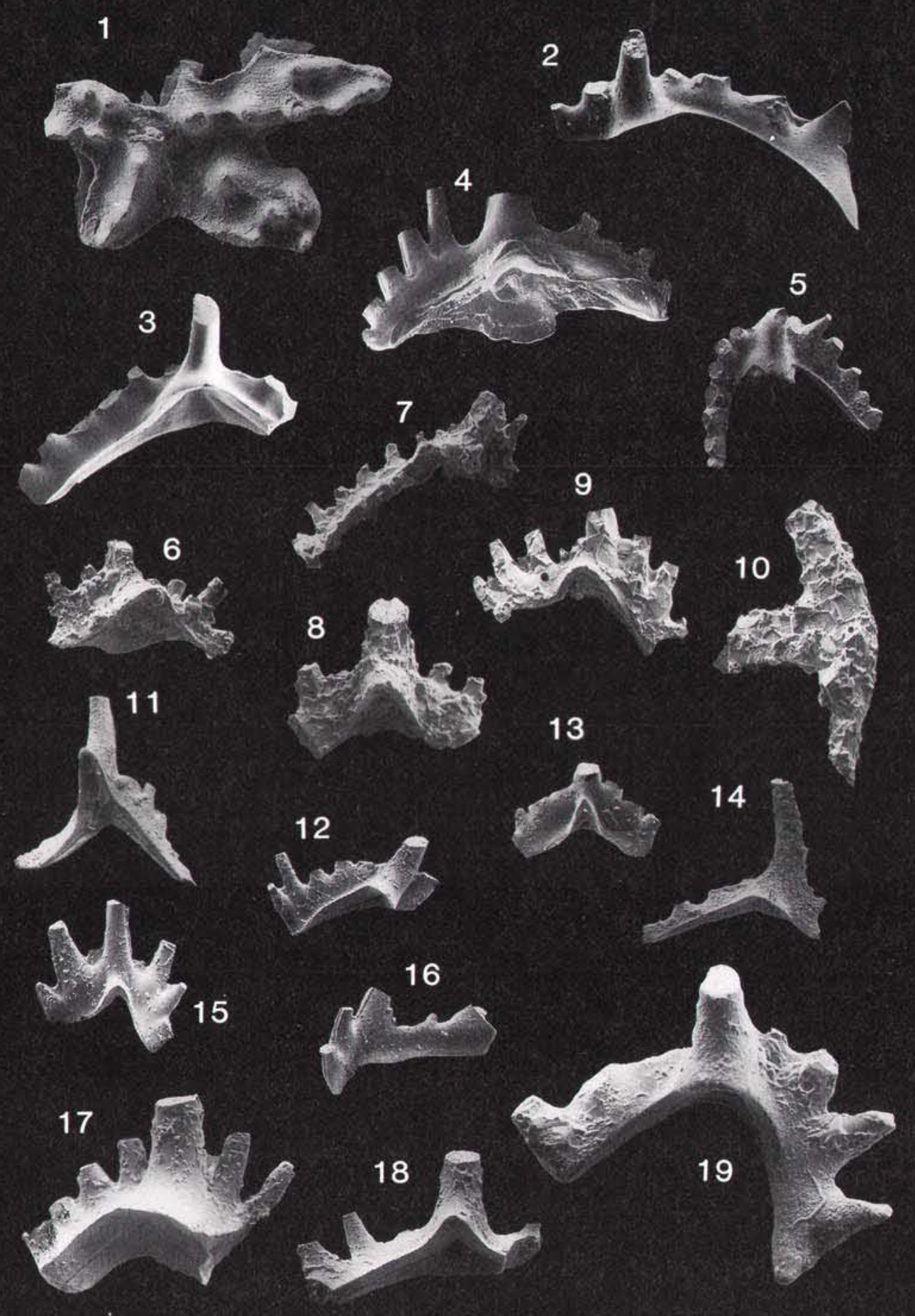


celloni and $P$. amorphognathoides Biozones of Europe and North America.

\author{
Kockelella aff. K. patula (Walliser) Barrick \& \\ Klapper, 1976 \\ Plate 10, fig. 1
}

$\mathrm{v}^{*}$ aff. 1964 Kockelella patula Walliser, p. 39, pl. 7, fig. 2; pl. 15 , fig. 16.

Description. Pa element. A scaphate platform fragment consisting of four lancolate processes, each bearing a series of tall, irregular nodes, or coalescing nodes to high sinuous ridges. The ornament is irregularly arranged along the centre of the processes. The entire surface is shallowly excavated, broad grooves extend beneath the processes and become shallow distally.

Remarks. A single, incomplete specimen is present in GGU sample 256351 (fig. 3), the only conodont from this reconnaissance sample. Morphologically it is similar to K. patula Walliser (1964) and Barrick \& Klapper (1976), but differs in having an upper ornament of irregular nodes.

\section{Genus Oulodus Branson \& Mehl, 1933b \\ 1933b Oulodus Branson \& Mehl, p. 116. \\ 1935a Gyrognathus Stauffer, p. 144. \\ 1935b Barbarodina Stauffer, p. 602. \\ 1969 Ligonodina Jeppsson, p. 19. \\ 1971 Delotaxis Klapper \& Philip, p. 446.}

Type species. Cordylodus serratus Stauffer, 1930, p. 124; from the Ordovician, Decorah Shale of Minnesota. Senior subjective synonym of Oulodus mediocris Branson \& Mehl (1933b, p. 116), the originally designated type species, by subsequent designation of Sweet \& Schönlaub $(1975$, p. 45$)$.

Diagnosis. Refer to Sweet \& Schönlaub (1975, p. 45).

Remarks. Within the Greenland collections the apparatuses of three Oulodus species have been reconstructed, but remain in open nomenclature due to low specimen numbers and/or poor preservation. A further eight indeterminate species groups contain individual Oulodus specimens, occurring within a single or closely related samples. These include new taxa, but cannot be confidently grouped into apparatuses. Thus they are illustrated and described informally.
Oulodus sp. A Aldridge, 1979

Plate 10, figs 11-16

v 1979 Oulodus sp. A Aldridge, p. 13, pl. 2, figs 13-16.

Description. ?Pa element. Described as the M element of Oulodus sp. A by Aldridge $(1979$, p. 13).

$\mathrm{Pb}$ element. Digyrate, with asymmetrically arched antero-lateral processes and strongly, posteriorly inclined cusp. The lateral processes are subequal in length and develop an angle of approximately $160^{\circ}$ between their inner faces; the inner process is bowed posteriorly and bears two to four compressed, discrete denticles, the most distal of which is commonly smaller than the others. The outer process bears four or five, posteriorly inclined denticles which are oval in cross section, closely packed and separated by narrow ' $v$-shaped' spaces. The basal cavity is posteriorly extended beneath the cusp, as a broad tapering groove and has a narrower groove along the processes. It is deeply excavated beneath the cusp, extending beneath the processes as narrow grooves.

$M$ element. Dolabrate with a tall cusp, long posterior process and short anticusp; the cusp is gently inwardly recurved and occasionally slightly inclined posteriorly. The short, anteriorly inclined anticusp bears one or two discrete, peg-like denticles. A straight posterior process extends from the base of the cusp at an angle of approximately $80^{\circ}$, its upper edge is twisted outwards, and bears up to five compressed, closely packed denticles, oval in cross section and separated by tight 'u-shaped' spaces; the most proximal denticle is smaller than the others. The inner margin of the basal cavity is expanded laterally beneath the posterior edge of the cusp, the cavity tapers rapidly, extending to the tips of the posterior process and anticusp as a narrow groove.

$S a, S b$, and Sc elements. As described by Aldridge (1979, p. 13).

Remarks. Aldridge (1979, p. 13) described elements of Oulodus sp. A. Aldridge from GGU 184125, Odins Fjord Formation, Peary Land. His reconstruction of its apparatus is extended to include ? $\mathrm{Pa}, \mathrm{Pb}$ and $\mathrm{M}$ elements, with his $\mathrm{M}$ element questionably reassigned to the Pa position. Aldridge (1979, p. 13, pl. 2, fig. 12) referred a single neoprioniodontan (M) element to $\mathrm{Ou}$ lodus sp. B Cooper which is morphologically similar to the newly described $\mathrm{M}$ element of Oulodus sp. A Aldridge. The P, Sa and Sb elements of Oulodus sp. B Cooper $(1975$, pl. 2, figs $18,19,21)$ are morphologically distinct from their counterparts in Oulodus sp. A Aldridge. The $\mathrm{Pb}$ element of Oulodus jeannae is similar to that of Oulodus sp. A Aldridge. Study of the specimen 
figured by Sweet \& Schönlaub (1975, pl. 1, fig. 14) shows it to have a shorter, more triangular, basal cavity extension beneath the cusp. Nowlan (1981, p. 264, fig. 4) figured $M$ and $S b$ elements which are similar to those of Oulodus sp. A. Aldridge, but his specimens were pre-P. celloni Biozone in age, and may be from an older apparatus. All the Greenland specimens are thermally mature (C.A.I. 3-4) and no white matter is visible.

Occurrence. Found only in Pterospathodus celloni Biozone strata of Peary Land and Kronprins Christian Land.

\section{Oulodus sp. A}

Plate 10, figs 2-5

Description. Only a single well-preserved specimen of each element has been recovered. Pa element modified digyrate with more or less horizontally directed lateral processes. The cusp is slightly offset posteriorly from the plane of the process denticulation. The inner process is shorter than the outer, posteriorly bowed with upper edge anteriorly twisted. M element digyrate, the outer process much longer than the inner, is inwardly bowed; the inner process is bowed inwardly and directed antero-laterally. Sa element alate; Sb tertiopedate with posteriorly twisted lateral processes and short posterior process.

Remarks. The elements of Oulodus sp. A are similar to those of Oulodus? kentuckyensis McCracken \& Barnes $(1981$, p. 80 , pl. 1 , figs $12,13,15)$ in the distribution of white matter and the lower surface morphology of the elements. Until more specimens become available and a complete apparatus structure can be elucidated, it is difficult to assess whether Oulodus sp. A is synonymous with $O . ?$ kentuckyensis. The $\mathrm{Pa}$ and $\mathrm{Sb}$ elements of Oulodus sp. A also bear a similarity to those described by Sweet \& Schönlaub (1975, p. 49, pl. 1, figs 19-24) in the apparatus of Oulodus jeannae. Study of their figured $\mathrm{M}$ element shows it to differ in having a more steeply inclined outer-lateral process and lacks an inner-lateral process.

Occurrence. Found only in GGU 216837 and 216842 of mid Llandovery (fig. 21).

\section{Oulodus sp. B}

Plate 10 , figs $6-10$

Description. Pa element digyrate with a broadly expanded lower surface and short inwardly bowed antero- lateral processes. The cusp is curved posteriorly, oval in cross-section and basally expanded. The inner process is shorter than the outer. A deep basal pit is located beneath the cusp. M element digyrate with a short inner process. Sa element alate, the basal cavity is expanded posteriorly beneath the cusp and its edge is upturned into a broad symmetrical arch. The cavity narrows rapidly, extending as a groove which terminates close to the tip of the inner process. Sb element tertiopedate lacking a well developed posterior process. The basal cavity is similar to that in the Sa, maximum expansion occurring beneath the inner edge of the cusp, the cavity only extends to the midlength of the lateral processes. Sc element bipennate, the basal cavity extends to the tips of the processes as two narrow grooves. All S elements possess a basal pit beneath the cusp.

Remarks. This apparatus reconstruction is based on $\mathrm{Ou}$ lodus elements in sample GGU 274720, with additional specimens from GGU 274721 and 274738. Oulodus sp. nov. A Aldridge \& Mohamed (1982, pl. 1, figs 34-39) has similar $\mathrm{Pa}$ and $\mathrm{S}$ elements but differs in the morphology of the M element.

Occurrence. Found only in middle Llandovery strata of Kronprins Christian Land (fig. 8).

Oulodus sp. indet. group 1

Plate 10, fig. 17

Remarks. This group is represented by two separate occurrences of incomplete, large, robust, Oulodus $\mathrm{P}$ elements with broad expanded basal cavities. They are found in GGU 256375 and 274722 (figs 6, 8) and represent the only upper Ordovician species of Oulodus recorded from North Greenland. These specimens bear little resemblance to other Ordovician species of Oulodus and probably represent a new species.

Oulodus spp. indet. group 2

Plate 10, figs 18-19; plate 11, fig. 1

Remarks. This group of elements is found only in GGU 274754 (fig. 8), and probably contains representatives of more than one apparatus. Elements are assigned to $S a$, $\mathrm{Sb}$ and $\mathrm{Sc}$ positions; the $\mathrm{Sb}$ is distinctive in having a broadly arched, posterior lip to the basal cavity, and it may be part of an apparatus including elements from Oulodus spp. indet. groups 3 and 4 (plate 11, figs 2-5). A similar element was referred by McCracken \& Barnes (1981, pl. 6, fig. 14) to the apparatus of Oulodus? kentuckyensis. 
Oulodus spp. indet. group 3

Plate 11, figs 2-3

Remarks. Two large robust elements from GGU 274747 (fig. 8) are assigned to $\mathrm{Pb}$ and Sa positions. Both have broad, upwardly arched, lower posterior margins to the basal cavity and a deep basal pit beneath the cusp, which extends laterally as two deep grooves. The lateral processes of the Sa element (plate 11, fig. 2) are twisted upwards at a quarter of their length, to form an angle of $90^{\circ}$ with the posterior edge of the cusp. The $\mathrm{Pb}$ element differs from that referred to Oulodus jeannae by Sweet \& Schönlaub (1975) in having a less steeply upturned lower posterior margin to the basal cavity.

Oulodus spp. indet. group 4

Plate 11, figs 4-5

Remarks. This group contains $\mathrm{Pb}$ and $\mathrm{Sa}$ elements found in GGU 256388 (fig. 6). The Pb element is similar to that in Oulodus spp. indet. group 3, but its innerlateral process is not as steeply inclined downwards and the cusp of this specimen is posteriorly offset from the plane of the process. The Sa element has a similarly offset cusp. These specimens are similar to those in Oulodus spp. indet. group 2 and may be part of the same apparatus.

Oulodus spp. indet. group 5

Plate 11, figs 6-8

Remarks. Pb, Sa and Sb elements found in GGU 228901 (fig. 6) are probably referable to two apparatuses. The
Sb element (plate 11, fig. 6) has peg-like denticles and a short cusp, with a circular cross section. The $\mathrm{Pb}$ and $\mathrm{Sb}$ elements (plate 11, figs 7,8 ) bear compressed denticles and have a posteriorly restricted basal cavity expansion. These elements are similar to their counterparts in $\mathrm{Ou}$ lodus jeannae Sweet \& Schönlaub (1975, pl. 1, figs 20, 21 ), but the inner-lateral basal cavity in the Greenland $\mathrm{Pb}$ element is much broader, and the lateral processes of the Sb element are more tightly arched and posteriorly recurved.

Oulodus spp. indet. group 6

Plate 11, figs 9-10

Remarks. Includes a $\mathrm{Pb}$ and an $\mathrm{M}$ element from GGU 274758 (figs 8,9). The $M$ element differs from that in Oulodus jeannae Sweet \& Schönlaub (1975) in having a narrow, groove-like, basal cavity and an adenticulate inner-lateral process.

Oulodus spp. indet. group 7

Plate 11, figs 11-13

Remarks. This group includes the Oulodus elements in GGU 242890 and 242894 (fig. 16). All have peg-like denticulation and deep lateral processes of which one is highly twisted towards the posterior. The ?P element (plate 11, fig. 12) is broken, but appears to have consisted of an extremely broad cusp and two lateral processes, the outer posteriorly recurved and directed downwards. An element with similar morphology was referred to Oulodus? annianus by Schönlaub (1975b, p.

\section{Plate 11}

Fig. 1. Oulodus spp. indet. group 2.

1. inner-lateral view of Sc element, $\times$ 40; MGUH 17.774 from GGU 274754.

Figs 2, 3. Oulodus spp. indet. group 3.

Specimens from GGU 274747, × 40 .

2, posterior view of S element; MGUH 17.775.

3, lower view of $\mathrm{Pb}$ element; MGUH 17.776.

Figs 4, 5. Oulodus spp. indet. group 4.

Specimens from GGU 256388, × 40 .

4, inner-lateral view of P element, MGUH 17.777.

5, posterior view of Sa element; MGUH 17.778.

Figs 6-8. Oulodus spp. indet. group 5.

Specimens from GGU 228901, × 40.

6, oblique upper view of Sb element; MGUH 17.779.

7 , lower view of $\mathrm{Pb}$ element; MGUH 17.780.

8, posterior view of Sa element; MGUH 17.781.

Figs 9, 10. Oulodus spp. indet. group 6.

Specimens from GGU 274758, × 60 .

9, inner-lateral view of $M$ element; MGUH 17.782.

10, oblique lateral view of $\mathrm{Pb}$ element; MGUH 17.783.

Figs 11-13. Oulodus spp. indet. group 7.

11, inner-lateral view of Sc element, $\times 40$; MGUH 17.784 from GGU 242890.

12, oblique inner-lateral view of ?P element, $\times 60$; MGUH 17.785 from GGU 242894.

13 , oblique posterior view of ?Sb slement, $\times 60 ; \mathrm{MGUH}$ 17.786 from GGU 242890 . 

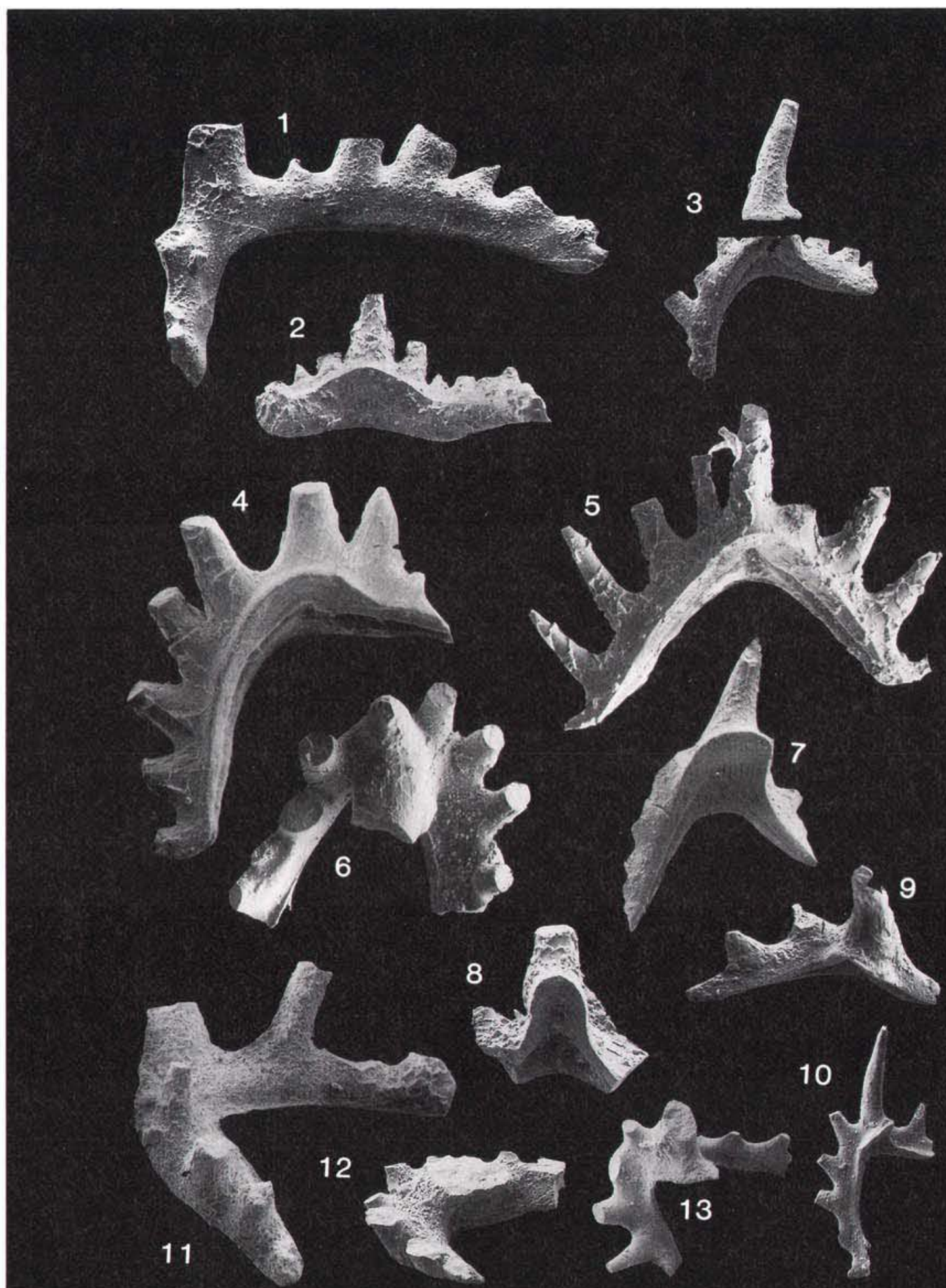
51 , pl. 1, fig. 16). The ?Sb element (plate 11, fig. 13) is similar; its outer-lateral process is steeply directed downwards, with the denticles directed almost horizontally outwards. The inner process of the Sc element (plate 11, fig. 11) diverges from the antero-lateral edge of the cusp and is steeply inclined downwards forming an angle with its lower edge of approximately $50^{\circ}$ to that of the posterior process. This specimen approaches the morphology exhibited by the Sc element of Oulodus petila (Nicoll \& Rexroad, 1969) sensu Barrick \& Klapper (1976, pl. 4, fig. 33).

Oulodus spp. indet. group 8

Plate 12, figs 1-3

Remarks. GGU 216729 (fig. 16) contains three Oulodus elements. The $\mathrm{M}$ element (plate 12 , fig. 2 ) is dolabrate and is similar to that of Aspelundia fluegeli (Walliser). It differs in having a less laterally compressed cusp and the inner lower margin of the basal cavity is arched upwards and expanded inwards beneath the posterior edge of the cusp. The posteriorly inclined denticles on the arched posterior process are circular in cross section and closely packed. The ?Sb element (plate 12, fig. 3) approaches the morphology of its counterpart in the apparatus of Oulodus sp. B Cooper (1975, p. 997, plate 2, fig. 20).

\section{Plate 12}

Figs 1-3. Oulodus spp. indet. group 8.

All specimens from GGU $216729, \times 60$.

1, posterior view of Sb element; MGUH 17.787.

2 , inner-lateral view of M element, MGUH 17.788.

3 , oblique posterior view of ?Sb element; MGUH 17.789.

Figs 4-12. Ozarkodina broenlundi Aldridge.

All specimens from GGU $184125, \times 60$ unless otherwise stated.

4, lateral view of Pa element; MGUH 14.408 (Aldridge, 1979, pl. 1, fig. 18).

5, lateral view of Pa element; MGUH 14.049 (holotype) (Aldridge, 1979, pl. 1, fig. 19)

6. upper view of Pa element; MGUH 14.051 (Aldridge, 1979 , pl. 1, fig. 21).

7. inner-lateral view of $\mathrm{Pb}$ element; MGUH 14.050 (Aldridge, 1979, pl. 1, fig. 20).

8, inner-lateral view of M element; MGUH 14.052 (Aldridge, 1979, pl. 1, fig. 22).

9. posterior view of Sa element; MGUH 14.054.

10, posterior view of Sb element; MGUH 14.055 (Aldridge, 1979, pl. 1, fig. 25).

11. inner-lateral view of Sc element; MGUH 14.053 (Aldridge, 1979, pl. 1, fig. 23).
Genus Ozarkodina Branson \& Mehl, 1933a

1933a Ozarkodina p. 51.

1933a Plectospathodus p. 47.

1933a Spathodus p. 46 (non Boulenger, 1900).

1941 Spathognathodus, p. 98.

1969 Hindeodella; Jeppsson, p. 13.

1970 Ozarkodina; Lindström, p. 439.

Diagnosis. Refer to Barrick \& Klapper (1976, p. 78).

Type species. Ozarkodina typica, by original designation of Branson \& Mehl (1933a, p. 51); from the Silurian, Bainbridge Formation of Missouri. A junior subjective synonym of Ozarkodina confluens (Branson \& Mehl, 1933a).

Remarks. Twelve species of Ozarkodina are present in the Greenland collections; these can be referred to three distinct groups based upon $\mathrm{M}$ element morphology and the white matter distribution in the $\mathrm{Pa}$ elements. The groups include those species similar to $O$. confluens Branson \& Mehl (such as $O$. broenlundi Aldridge), species similar to $O$. excavata excavata, (for example Ozarkodina n. sp. C and $O$. excavata from Greenland) and species similar to $O$. polinclinata Nicoll \& Rexroad (such as $O$. pirata Uyeno \& Barnes). The last group has an M element similar to Aspelundia flue. geli. Kuwano (1982) suggested that the apparatus of $O$. excavata excavata contained two morphologically dis-
12, microstriations on the denticles of $\mathrm{Pa}$ element, $\times 360$; MGUH 14.049.

Figs 13-22. Ozarkodina excavata (Branson \& Mehl).

All specimens $\times 60$.

13, lateral view of Pa element; MGUH 17.791 from GGU 256379.

14, lateral view of $\mathrm{Pa}$ element; MGUH 17.792 from GGU 256382.

15, lateral view of Pa element; MGUH 17.793 from GGU 256388.

16, lateral view of $\mathrm{Pa}$ element; MGUH 17.794 from GGU 256383.

17, inner-lateral view of $\mathrm{Pb}$ element; MGUH 17.795 from GGU 274721.

18 , inner-lateral view of the M element; MGUH 17.796 from GGU 256383.

19, posterior view of ?Sb element; MGUH 17.797 from GGU 256383.

20, inner-lateral view of ?Sc element; MGUH 17.798 from GGU 256384.

21, lateral view of $\mathrm{Pa}$ element; MGUH 17.799 from GGU 228978.

22, lateral view of Pa element; MGUH 17.800 from GGU 216772 . 


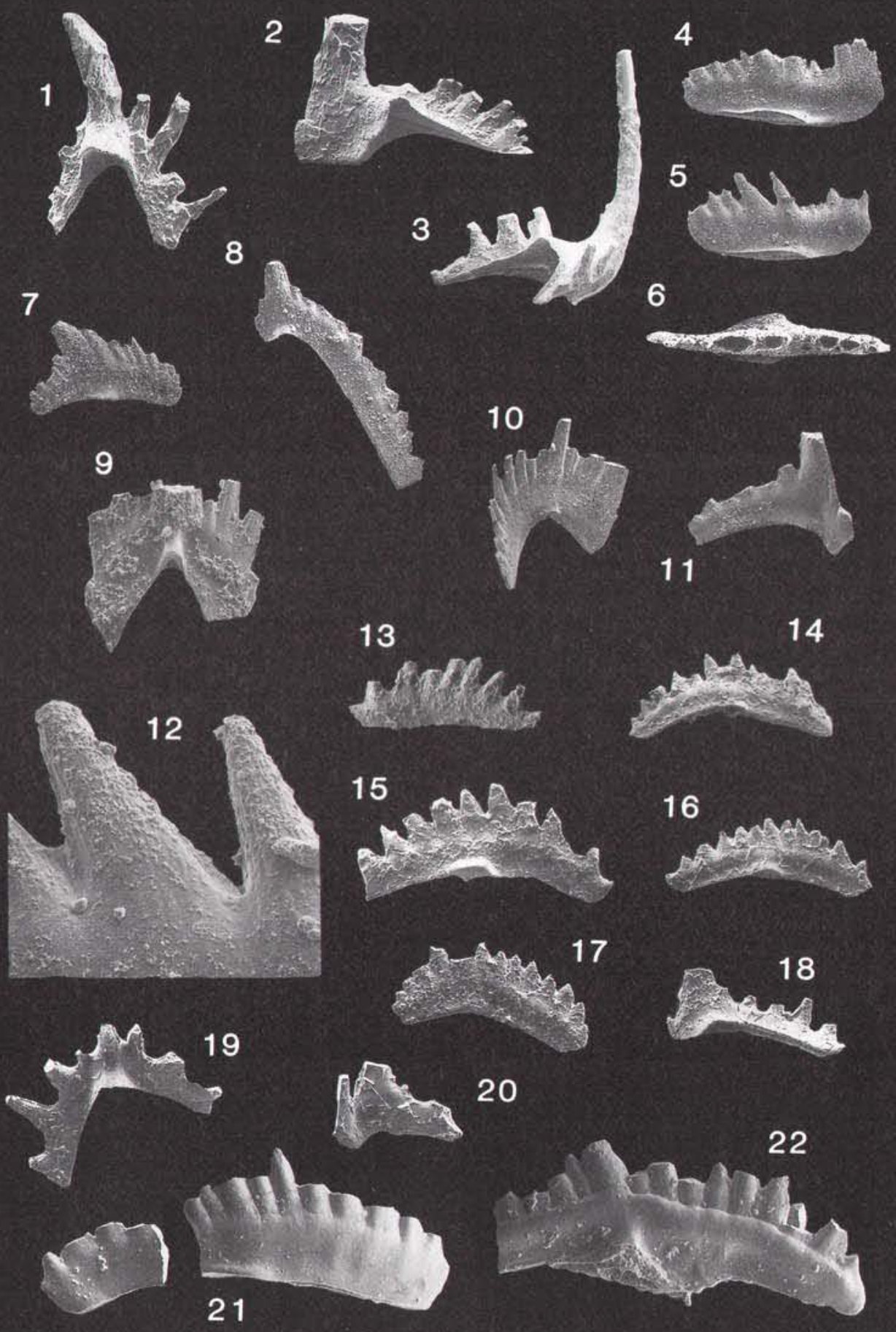


tinct pairs of Sb elements, which provides further evidence for the separation of this and related species from $O$. confluens. If the informal groups can be confirmed as separate lineages, then Ozarkodina is separable into at least three subgenera.

\section{Ozarkodina broenlundi Aldridge, 1979 \\ Plate 12, figs 4-12}

v1979 Ozarkodina broenlundi Aldridge, p. 16, pl. 1, figs $18-25$.

Holotype. MGUH 14049, Aldridge, 1979, pl. 1, fig. 19; Pa element from sample GGU 184125, upper part of the Odins Fjord Formation at Børglum Elv, Peary Land, in eastern North Greenland.

Diagnosis. Refer to Aldridge (1979, p. 16).

Description. Refer to Aldridge (1979, pp. 16-17).

Remarks. This species is distinguished from $O$. confluens Branson \& Mehl by its variable height and irregularly, but well spaced, denticles, shallow groove-like basal cavity and lack of a posterior extension of the cusp in the $\mathrm{Sa}$ and $\mathrm{Sb}$ elements. The $\mathrm{Pa}$ element of $O$. broenlundi has a similar basal cavity and high central denticles to its counterpart in $O$. pirata, but is distinguished by the high anterior denticles.

Occurrence. Found in Pterospathodus celloni Biozone faunas of Peary Land, Kronprins Christian Land, Wulff Land and Washington Land.

Ozarkodina excavata (Branson \& Mehl, 1933a) Plate 12, figs 13-22; plate 13, fig. 1

v1933a Prioniodus excavatus, p. 45, pl. 3, figs 7, 8 .

v1933a Ozarkodina simplex, p. 52, pl. 3 figs 46, 47.

v1933a Trichognathus excavata, p. 51, pl. 3, figs 35,36

v1953 Prioniodella inclinata Rhodes, p. 324, pl. 23, figs 233-235.

1953 Trichonodella aboraflexa Rhodes, p. 312, pl. 23, figs $231,241,242$.

1953 Plectospathodus extensus Rhodes, p. 323, pl. 23 , figs $236-240$.

v1957 Spathognathodus inclinatus; Walliser, p. 47, pl. 1, figs $16-20$.

v1957 Ozarkodina media Walliser, p. 40, pl. 1, figs $21-25$.

v1957 Prioniodina bicurvata; Walliser, p. 46, pl. 2, figs 18,19 .

v1957 Trichonodella excavata; Walliser, p. 48, pl. 3, figs $3,4,6,9$.

v1957 Plectospathodus extensus; Walliser, p. 43, pl. 3, figs 1,2 ; fig. 3 . v1957 Hindeodella equidentata; Walliser, p. 34, pl. 2, fig. 23.

v1964 Spathognathodus inclinatus inclinatus; Walliser, p. 76 , pl. 8 , fig. 6 ; pl. 9 , fig. 9 ; pl. 19 , figs 6-16.

v1964 Ozarkodina media; Walliser, p. 58, pl. 8, fig. 5; pl. 9, fig. 8; pl. 26, figs $19-25,27-34$.

v1964 Neoprioniodus excavatus; Walliser, p. 49, pl. 8, fig. 4 ; pl. 9, fig. 7 ; pl. 9, fig. 7; pl. 29, fig. 2b; text fig. $5 c$.

v1964 Trichonodella excavata; Walliser, p. 89, pl. 31 , fig. 26.

v1964 Plectospathodus extensus; Walliser, p. 64, pl. 8, fig. 1 ; pl. 9, fig. 4; pl. 30 , figs 13,14 .

v1964 Hindeodella equidentata; Walliser, p. 36, pl. 8, fig. 3 ; pl. 9, fig. 6 ; pl. 32, fig. 11 .

1969 Hindeodella excavata; Jeppsson, p. 18, figs 1 G-L; fig. 3 .

v1971 Ozarkodina simplex; Rexroad \& Craig, p. 693, pl. 80 , figs $26-31$.

v1971 Prioniodella inclinata; Rexroad \& Craig, pl. 80, fig. 25.

v1971 Ozarkodina media; Rexroad \& Craig, pl. 80, figs 24,25 .

v1971 Neoprioniodus excavatus; Rexroad \& Craig, p. 692 , pl. 80 , figs $6-9$.

v1971 Plectospathodus extensus; Rexroad \& Craig, p. 698 , pl. 82 , figs 1,2 .

1972 Hindeodella excavata; Jeppsson, p. 61, pl. 1, fig. 30 ; text fig. $1 \mathrm{~A}$.

v1972 Spathognathodus inclinatus; Aldridge, p. 213, pl. 4 , figs 15,16 .

v1972 Plectospathodus extensus; Aldridge, p. 207, pl. 7, figs $21,22$.

1974 Hindeodella excavata; Jeppsson, pl. 4, figs 1-17 (see for further synonymy).

p1975 Ozarkodina plana; Sweet \& Schönlaub, pl. 52, pl. 1 , figs $2, ? 5$, only.

p1975 Spathognathodus inclinatus inclinatus; Schönlaub \& Zezula, pl. 2, figs 10a-b only.

v1975 Ozarkodina excavata; Aldridge, pl. 2, figs 9-14.

1975 Ozarkodina protoexcavata Cooper, p. 1106, pl. 3, figs $1-6$

1976 Ozarkodina excavata excavata; Barrick \& Klapper, p. 78, pl. 4, figs 13-23, 26.

1976 Ozarkodina excavata; Cooper, p. 215 , pl. 2, figs $1-4,6,7$.

?1976 Spathognathodus inclinatus; Miller, pl. 8, figs 1, 32.

?1976 Ozarkodina media; Miller, pl. 8, figs 21, 35, 36.

?1976 Ozarkodina simplex; Miller, pl. 8, figs 34.

?1976 Trichonodella excavata?; Miller, pl. 8, fig. 13.

1976 Ozarkodina excavata; Cooper, p. 188, pl. 16 , figs $8-15$.

1978 Ozarkodina excavata excavata; Rexroad, Noland \& Pollock, p. 9, pl. 1, figs 17-22.

1978 Ozarkodina excavata; Helfrich, pl. 2, figs 1-7.

1980 Ozarkodina excavata excavata; Mayr, Uyeno, Tipnis \& Branes, pl. 32.1, figs 28, 32 .

1980 Ozarkodina excavata; Helfrich, pl. 2, figs 31-38.

1981 Ozarkodina excavata excavata; Nowlan, pl. 6, figs $10-16,18$

1982 Ozarkodina excavata; Aldridge \& Mohamed, pl. 1, figs 16-17.

v1983 Ozarkodina excavata; Mabillard \& Aldridge, pl. 3, figs 1-6.

1985 Ozarkodina excavata excavata; Savage, p. 722, figs $14 \mathrm{~A}-\mathrm{L}$.

1986 Ozarkodina excavata excavata; Bischoff, p. 134 pl. 25 . figs $35-40 ; \mathrm{pl}$. 26 , figs $1-40$. 
Neotype. Neoprioniodus excavata Branson \& Mehl; Rexroad \& Craig, p. 692, pl. 80, fig. 7. From sample 2, Bainbridge Formation, Lithium, Missouri.

Diagnosis. Refer to Jeppsson (1974, p. 29).

Description. All elements of $O$. excavata have been adequately described and reference should be made to the works cited in the synonomy. Specimens of the $\mathrm{Pa}$ element from $P$. celloni Biozone samples have a conspicuous cusp situated just to the posterior of the midlength of the element.

Remarks. Ozarkodina excavata from Greenland differs only slightly from Upper Silurian $O$. excavata excavata in the morphology of its $\mathrm{M}$ and ?Sb elements; all known elements have a more oval basal cavity when viewed from beneath. White matter is not visible in the Greenland specimens.

Ozarkodina n. sp. C has an arched, blade-like $\mathrm{Pa}$ element similar to that of $O$. excavata, but differs in having larger denticles to the posterior of the apical denticle and an asymmetrically developed, narrowly flaring basal cavity. The other elements in the apparatus are similar to their counterparts in O. excavata. Ozarkodina $\mathrm{n}$. sp. C appears in the lowermost Silurian of Wulff Land and may be a stratigraphical or geographical variant of $O$. excavata.

Occurrence. Found infrequently in Llandovery samples: most commonly in Peary Land.

\section{Ozarkodina aff. O. gulletensis? (Aldridge, 1972) Plate 13, figs 2, 3 \\ ?v aff.1972 Spathognathodus gulletensis Aldridge, p. 212, pl. 4, figs 9-12. \\ ?v aff. 1979b Hindeodella gulletensis; Jeppsson, p. 224, pl. 72, figs 14-22.}

Description. Pa element. A single specimen of a carminate element with an arched denticulate upper edge and straight lower edge. A posteriorly inclined, prominent apical denticle is situated to the posterior of the midlength. The anterior process is approximately twice as high as the posterior process and bears seven squat, triangular denticles. The denticles on both processes are fused almost to their apices. The posterior process is much shorter than the anterior, bearing three denticles which are subequal in height. The basal cavity is situated beneath the apical denticle and has asymmetrically flared lips; it extends to the tips of the processes as a tapering groove. The inner lip is situated slightly post- erior of the outer lip and bears a single peg-like denticle. In lateral view, white matter completely fills each denticle; its base defines a sharp linear trace which is deepest beneath the apical denticle and is inclined upwardly along the processes. The two denticles at the end of the anterior process contain white matter only at their tips.

$\mathrm{Pb}$ element. Angulate, strongly arched upper edge and straight lower edge. The cusp is posteriorly inclined, flattened lenticular in cross section; it is approximately twice as broad, but only marginally taller than the largest denticles. The anterior process is approximately twice as high as the posterior process and bears four compressed denticles. These are almost fused to their apices and decrease in height (but not width) distally; the most proximal denticle is fused almost completely to the edge of the cusp. The posterior process is short and slightly inwardly bowed bearing only a single, broad, compressed denticle. The basal cavity is expanded almost symmetrically beneath the cusp; its inner edge is upturned beneath the cusp, forming a broad arch. The basal cavity tapers anteriorly and posteriorly, extending to the tips of the element as an extremely narrow groove. In lateral view, white matter is seen to fill each denticle completely above its base; white matter does not extend downwards into the processes.

Remarks. The white matter distribution in the $\mathrm{Pa}$ element is similar to that in its counterpart in the apparatus of $O$. gulletensis Aldridge. The former element, however, has an arched upper edge, fewer denticles and an asymmetrically expanded basal cavity which develops a denticle on its inner lip. Study of the holotype and paratype specimens of $O$. gulletensis shows the number and height of the denticles to be intraspecifically variable. The basal cavity expansion and white matter distribution do not vary between specimens. The $\mathrm{Pb}$ element of $O$. aff. $O$. gulletensis? is smaller than that referred to $H$. gulletensis by Jeppsson (1979b, pl. 2, fig. 17). The Greenland specimen is probably a juvenile, and it has a white matter distribution similar to juvenile specimens of the $\mathrm{Pb}$ element of $H$. confluens (Jeppsson, 1979b, pl. 6, fig. 1). The asymmetrical basal cavity development of $O$. aff. $O$. gulletensis? is probably sufficient to separate it as a new species.

Occurrence. Found only in samples of Pterospathodus celloni Biozone age from Washington Land and Wulff Land. 
Ozarkodina cf. O. hadra (Nicoll \& Rexroad, 1969)

Plate 13, figs 4-9

v cf. 1969 Spathognathodus hadros Nicoll \& Rexroad, p. 59 , pl. 5 , figs 17,18 .

Description. Pa element. Carminate, shallowly arched, element with subparallel upper and lower edges. A small, though prominent, apical denticle is situated just to the posterior of midlength; it is compressed and posteriorly inclined. The deeper and longer anterior process bears seven compressed, almost completely fused denticles; erect to slightly posteriorly inclined, the three distal denticles are larger than the others. The posterior process bears five to six posteriorly inclined denticles, the two most proximal of these are slightly smaller than the others, which tend to increase in size towards the centre of the process. The basal cavity is situated beneath the apical denticle and is slightly asymmetrically expanded; its inner flare is situated just to the anterior of the outer flare. Several specimens have a slightly less well developed inner expansion of cavity. The basal cavity is shallowly excavated beneath the apical denticle, extending as an extremely narrow groove, terminating at approximately the midlength of the anterior process; there is no groove beneath the posterior process.
$\mathrm{Pb}$ element. Strongly arched, angulate element, the cusp is lenticular in cross section with costate anterior and posterior edges; the outer face of the cusp is weakly microstriated. The inwardly bowed anterior process forms an angle of $100^{\circ}-120^{\circ}$ to the anterior edge of the cusp; this bears three laterally triangular, broad, basally fused denticles, of which the most proximal is smaller than the others. The posterior process is broken in the majority of specimens, bearing five broadly spaced denticles similar in shape and size to those on the anterior process. One specimen possesses a slightly outwardly directed posterior process. The basal cavity is flared beneath the cusp, has a circular lower outline and extends only a short distance beneath the anterior and posterior processes, terminating beneath the first proximal denticle of each process.

$M$ element. Modified tertiopedate with a short inner and strongly arched outer process, lacks a posterior process, anterior process reduced. The cusp is broad, lenticular in midlength cross section. The inner process bears one or two discrete, peg-like denticles; the outer process is occasionally inwardly bowed, bearing seven partially fused denticles with oval cross sections. The most proximal denticle is commonly much shorter than the others. The lower edge of the basal cavity is expanded and broadly upturned beneath the cusp. The cavity tapers rapidly to a narrow groove beneath the posterior process, terminating at approximately the

\section{Plate 13}

Fig. 1. Ozarkodina excavata (Branson \& Mehl).

1, ?inner-lateral view of $\mathrm{Pb}$ element, $\times 60$; MGUH 17.801 from GGU 228978.

Figs 2, 3. Ozarkodina aff. O. gulletensis (Aldridge). Specimens from GGU 216772, × 60 .

2, inner-lateral view of Pa element; MGUH 17.802.

3 , inner-lateral view of Pb element: MGUH 17.803.

Figs 4-9. Ozarkodina cf. $O$. hadra (Nicoll \& Rexroad). All specimens from GGU 82687, $\times 40$.

4. inner-lateral view of Pa element; MGUH 17.804 .

5, posterior view of Sa element; MGUH 17.805.

6, inner-lateral view of Pb element; MGUH 17.806.

7, inner-lateral view of M element; MGUH 17.807.

8, posterior view of Sb element; MGUH 17.808.

9, inner-lateral view of Sc element; MGUH 17.809.

Figs 10-16. Ozarkodina hassi (Pollock, Rexroad \& Nicoll). All specimens $\times 60$.

10, inner-lateral view of $\mathrm{Pa}$ element; MGUH 17.810 from GGU 274721.

11, inner-lateral view of Pa element: MGUH 17.811 from GGU 198806.
12, inner-lateral view of $\mathrm{Pb}$ element; MGUH 17.812 from GGU 274721.

13, inner-lateral view of M element; MGUH 17.813 from GGU 274721 .

14, posterior view of Sa element; MGUH 17.814 from GGU 254883.

15 , posterior view of Sb element; MGUH 17.815 from GGU 274721.

16, inner-lateral view of Sc element; MGUH 17.816 from GGU 254883.

Figs 17-19. Ozarkodina aff. O. hassi (Pollock, Rexroad \& Nicoll).

All specimens from GGU 274747, × 60 .

17, inner-lateral view of Pa element; MGUH 17.817.

18 , inner-lateral view of ?Pb element; MGUH 17.818.

19, inner-lateral view of ?M element; MGUH 17.819.

Figs 20-23. Ozarkodina pirata Uyeno \& Barnes. All specimens from GGU $274766, \times 60$.

20, inner-lateral view of Pa element: MGUH 17.820.

21, inner-lateral view of $\mathrm{Pb}$ element; MGUH 17.821 .

22. posterior view of Sa element; MGUH 17.822.

23, inner-lateral view of Pa element; MGUH 17.823. 
Plate 13
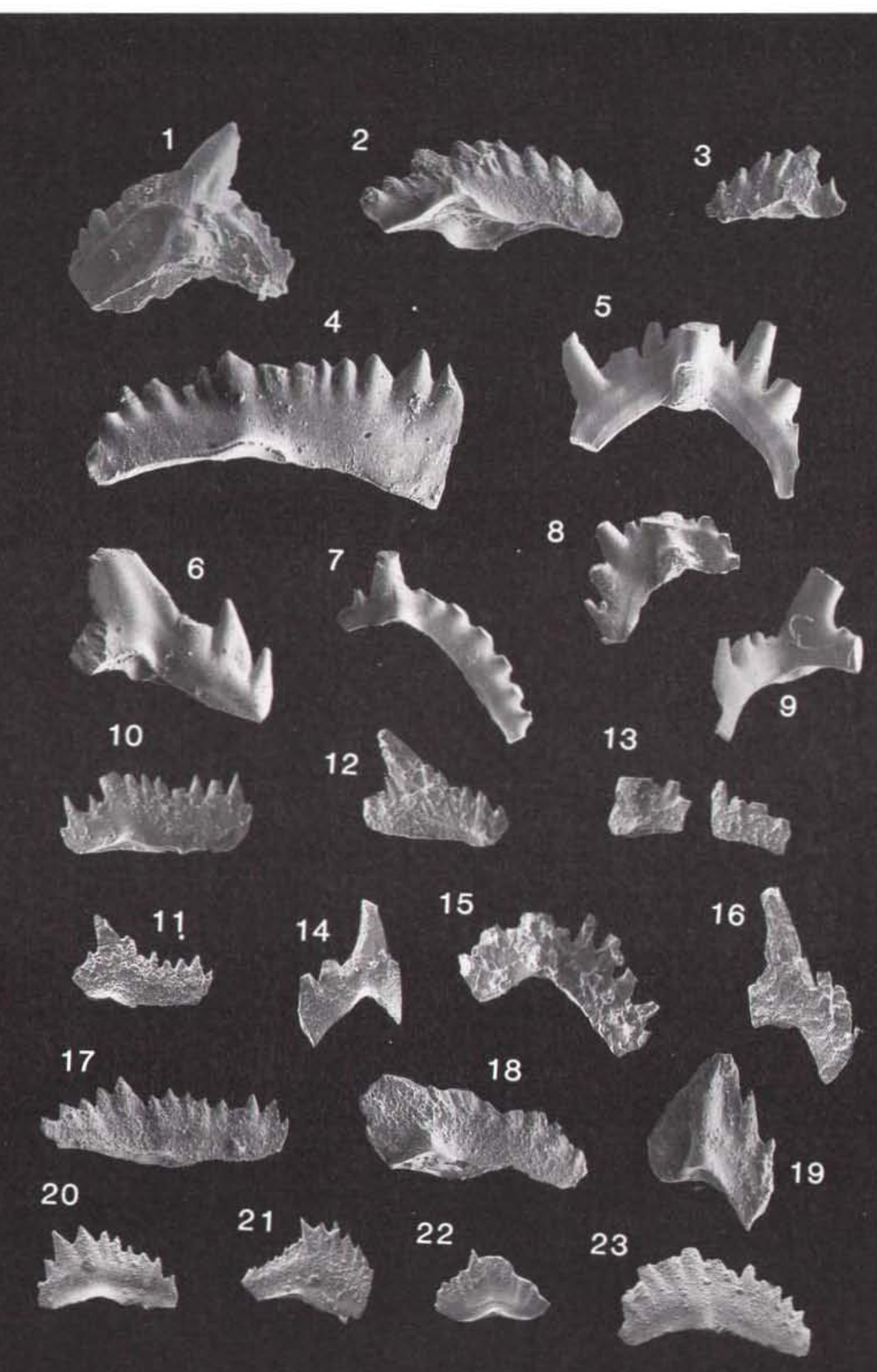
midlength of the process. The basal cavity does not extend beneath the anterior process.

Sa element. Alate with a tall, laterally compressed cusp. The lateral edges of the cusp are costate, its anterior face broadly convex, its posterior face shallowly expanded. The lateral processes form an angle of approximately $160^{\circ}$ between their lower edges; the processes are equal in length bearing four to five compressed denticles which are basally fused, tall and separated by broad ' $v$-shaped' spaces; the most proximal on each process is smaller than the others. In large specimens the faces of the processes may be slightly thickened. The basal cavity extends posteriorly beneath the cusp, it is deeply excavated and narrows laterally terminating beneath the first proximal denticle on each process.

Sb element. Modified tertiopedate element lacking a well developed posterior process. The cusp is broad and erect, its posterior face expanded only slightly. The lateral processes develop an angle of approximately $120^{\circ}$ between their lower edges; the inner is shorter and extends almost horizontally, it is posteriorly bowed and bears four closely packed, basally fused, compressed denticles. The outer process bears four large denticles, of which the central two are slightly larger than the others. The basal cavity, commonly filled with sediment, is extended posteriorly beneath the cusp where it is deeply excavated. Laterally the cavity tapers rapidly, to a narrow groove which extends to beneath the first proximal denticle on each lateral process.

Sc element. Bipennate with strongly inwardly curved anterior process. The cusp is tall, posteriorly inclined and oval in cross section; the anterior edge is weakly costate, the posterior more rounded. The anterior process forms an angle of $160^{\circ}$ between its lower edge and that of the posterior process; it bears four compressed denticles which increase in size distally, the most proximal denticle is partially fused to the cusp. The posterior process is broken in all specimens, extends horizontally from the cusp and bears compressed denticles similar to those on the anterior process. The basal cavity is expanded almost symmetrically beneath the cusp, tapering rapidly to a narrow groove which extends for only a short distance beneath the processes. Anteriorly the basal groove terminates beneath the first or second proximal denticle.

Remarks. The elements are typically large, with similar denticulation and basal cavity expansion. The Pa element differs from that of $O$. hadra in having three large, anterior, distal denticles and a prominent apical denticle. Klapper \& Murphy $(1975$, p. 37) illustrated similar specimens such as $O$. confluens delta morphotype, but these differ in having a nearly symmetrical, narrower, more posteriorly situated basal cavity. The Pa element of $O$. gulletensis Aldridge (1972) has a similar basal cavity, but lacks the high anterior distal denticles and arched lower edge. The Sa and Sb elements of its apparatus appear to lack the posterior extension of the cusp. (Jeppsson, 1979b, pl. 72, figs 14-22).

The Greenland specimens of $O$. cf. $O$. hadra are thermally mature, and it is difficult to see white matter. The high anterior denticles on the Pa element and morphology of the $\mathrm{M}$ and $\mathrm{S}$ elements suggest a close morphological affinity with $O$. confluens.

Occurrence. Found in the Pterospathodus celloni Biozone of Peary Land and Washington Land. GGU 82687 contains the most abundant specimens.

\section{Ozarkodina hassi (Pollock, Rexroad \& Nicoll, 1970) \\ Plate 13, figs $10-16$}

v1967 Spathognathodus cf. S. oldhamensis Rexroad, p. 49 , pl. 3 , fig. 3 .

v1967 Ozarkodina edithae; Rexroad, p. 40, pl. 2, fig. 6.

v1967 Synprioniodina cf. Prioniodus bicurvatus; Rexroad, p. 50 , pl. 3 , figs $9,10$.

$\mathrm{v}^{*} 1970$ Spathognathodus hassi; p. 760, pl. 111, figs 8-12.

1970 Ozarkodina cf. O. edithae; Pollock, Rexroad \& Nicoll, p. 756, pl. 111, figs 3, 4 .

1970 Synprioniodina bicurvata; Pollock, Rexroad \& Nicoll, p. 762, pl. 114, figs 16, 17 .

1970 Trichonodella $\mathrm{n}$. sp. Pollock, Rexroad \& Nicoll, p. 763 , pl. 113 , fig. 21 .

p1970 Plectospathodus flexuosus; Pollock, Rexroad \& Nicoll, p. 758, pl. 113, fig. 20; non fig. 19.

1970 Ligonodina? variabilis; Pollock, Rexroad \& Nicoll, p. 755 , pl. 114, figs $11,12$.

v1972 Spathognathodus hassi; Aldridge, p. 213, pl. 4, figs 2,3 .

v1972 Ozarkodina cf. O. edithae; Aldridge, p. 199, pl. 4 , fig. 17.

v1972 Synprioniodina bicurvata; Aldridge, p. 216, pl. 5, fig. 28.

v1972 Plectospathodus flexuosus; Aldridge, p. 208, pl. 7, fig. 24.

v1972 Ligonodina? variabilis; Aldridge, p. 189, pl. 8, fig. 14 .

v1975 Ozarkodina hassi; Aldridge, pl. 2, fig. 22.

1975 Ozarkodina hassi; Cooper, p. 1005, pl. 3, figs 1-12.

1977 Spathognathodus hassi; Liebe \& Rexroad, pl. 1, figs 20,21 .

1977 Ozarkodina aff. O. edithae; Liebe \& Rexroad, pl. 1, fig. 22.

1977 Synprioniodina bicurvata; Liebe \& Rexroad, pl. 1, fig. 6.

?1977 Plectospathodus flexuosus; Liebe \& Rexroad, pl. 2 , fig. 34 .

1977 Ligonodina variabilis; Liebe \& Rexroad, pl. 1, fig. 14 .

1981 Ozarkodina hassi; McCracken \& Barnes, p. 83, pl. 7, figs $1,2,4,6-13$.

1981 Ozarkodina hassi; Nowlan, pl. 5, figs 1, 2, 5, 6.

1981 Ozarkodina hassi; Fåhraeus \& Barnes, pl. 1, fig. 8 . 
1982 Ozarkodina hassi; Aldridge \& Mohamed, pl. 1, fig. 21.

v1985 Ozarkodina hassi; Aldridge, p. 78, pl. 3-1, fig. 4.

1987 Ozarkodina hassi; Over \& Chatterton, pl. 1, figs 1-2.

Holotype. Spathognathodus hassi Pollock, Rexroad \& Nicoll, 1970, p. 760, pl. 111, fig. 9. Sample 7-2, p. 747, from the lower Llandovery of Manitoulin Island, Ontario.

Emended diagnosis. Elements $\mathrm{Pa}, \mathrm{Pb}, \mathrm{M}, \mathrm{Sa}, \mathrm{Sb}, \mathrm{Sc}$ all with shallow, laterally expanded basal cavities. The carminiscaphate $(\mathrm{Pa})$ element is characterised by a prominent apical denticle and denticles of unequal height along the anterior process, almost completely fused. Denticles along the posterior process are shorter than those on the anterior in both the $\mathrm{Pa}$ and angulate $\mathrm{Pb}$ elements.

Description. Pa element. Refer to that of Spathognathodus hassi Pollock, et al. (1970, p. 760). This element shows ontogenetic variation in the Greenland specimens, larger forms having a more broadly flared basal cavity than smaller specimens. The youngest representatives of this species, from Bessels Fjord (plate 13, fig. 11) are more robust with a larger apical denticle and anterior process denticles. The processes of these specimens are thickened slightly beneath the denticle row.

$\mathrm{Pb}$ element. Refer to the description of Ozarkodina cf. O. edithae Walliser by Pollock et al. (1970, p. 756).

$M$ element. Compressed, dolabrate element comprising an erect cusp and arched, downwardly directed posterior process, bearing five compressed, fused denticles. The antero-basal corner of the cusp is slightly extended. The inner margin of the basal cavity is upturned and slightly expanded beneath the posterior edge of the cusp, extending as a slit-like groove to the tip of the posterior process.

Sa element. Alate element, the cusp is compressed and broad, slightly posteriorly inflated at its base. The lateral processes form an angle of approximately $100^{\circ}$ between their lower edges. Each process bears three or four compressed, partially fused denticles; these are tall and free from approximately midlength. The posterior edge of the basal cavity is upturned and slightly posteriorly flared beneath the cusp, extending as a tapering, shallow groove almost to the tips of the lateral processes.

Sb element. Refer to that of Plectospathodus flexuosus Branson \& Mehl by Aldridge (1972, p. 208).

Sc element. Bipennate compressed element; the cusp is lenticular in cross section. The anterior process is downturned and only slightly inwardly bowed, its upper edge forming an angle of $160^{\circ}-170^{\circ}$ with the anterior edge of the cusp, and bears up to four compressed, partially fused denticles. The posterior process is straight and horizontally directed from the base of the cusp, this process is broken in all specimens but bears compressed, posteriorly inclined, partially fused denticles. The basal cavity is excavated beneath the cusp, but only slightly laterally expanded, extending as a shallow groove almost to the tips of the processes.

Remarks. The apparatus of $O$. hassi present in the Greenland collection differs from that proposed by Cooper (1975) in the morphology of the M element. The Greenland specimens have a much reduced anterior process and a shallowly arched posterior process; they compare more closely with the $\mathrm{M}$ element proposed by McCracken \& Barnes (1981, p. 83) and confirmed by the topotype collections stored at the University of Nottingham. The $\mathrm{M}$ element designated by Cooper (1975, pl. 3, fig. 11 has a long inner-lateral process bearing four compressed denticles and a deep outer process with tall denticles. On the basis of process orientation it is suspected that this represents an $\mathrm{Sb}$ element of a different Ozarkodina species.

Previous synonymies of $O$. hassi have included Trichonodella sp. B Rexroad (1967, p. 53, pl. 3, fig. 17). Study of the figured specimen shows it to be incomplete; it is absent from the topotype sample and the Greenland collection and is not included in synonomy. Plectospathodus flexuosus Branson \& Mehl sensu Liebe \& Rexroad (1977) is tentatively included; it occurs in association with the $\mathrm{Pa}$ element, but the illustration is of insufficient quality to allow a firm decision.

$O$. hassi is distinct from $O$. oldhamensis Rexroad which has a $\mathrm{Pa}$ element with a much broader basal cavity, lacks a prominent apical denticle and has anterior denticles that are equal in height forming an almost straight upper edge to the anterior process.

Study of the holotypes of $O$. hassi, O. comptus (Pollock, Rexroad \& Nicoll) and $O$. oldhamensis (all Pa elements) shows them to have similar white matter distribution. Thus, diffuse as opposed to dense opaque white matter completely fills the denticles and has a sharply defined base which follows the outline of the lower edge of the element at approximately the midheight of the carina. These three species appear to be closely related.

Occurrence. Found in samples from central and eastern Peary Land, Kronprins Christian Land, J. P. Koch Fjord, Wulff Land and Bessels Fjord.

On Anticosti Island the first occurrence of $O$. hassi 
and/or $O$. oldhamensis is thought by McCracken \& Barnes (1981, p. 72) to be indicative of the OrdovicianSilurian boundary. $O$. hassi has been documented from Aeronian and lower Telychian strata of the Welsh Borderland (Aldridge, 1972, 1975).

\section{Ozarkodina aff. O. hassi (Pollock, Rexroad \&} Nicoll, 1970)

Plate 13, figs 17-19

Description. Pa element. A single, complete, carminate, inwardly bowed element with a more or less straight lower edge. The anterior process is longer and deeper than the posterior, both decrease in height distally. A tall, compressed apical denticle is situated posterior of midlength; it is lenticular in cross section and slightly posteriorly inclined. The anterior process bears eight compressed, irregularly spaced, basally fused denticles, of variable height; all are erect except the two most proximal. The posterior process bears four posteriorly inclined denticles which are fused to midheight and decrease in height distally. The basal cavity is symmetrically expanded beneath the apical denticle; in lower view it is lenticular in outline, broadest beneath the anterior edge of the apical denticle. The cavity terminates anteriorly and posteriorly beneath the third denticle on each process; posteriorly the cavity tapers gradually.

$? P b$ element. Two extremely poorly preserved fragments occur with the Pa element and may represent the $\mathrm{Pb}$ element of this apparatus. The most complete is figured; this is angulate and comprises a broad based cusp remnant and an anterior process that is inclined downwards. This process bears the fused remnants of eight compressed denticles. The basal cavity is broadly expanded beneath the cusp; its inner flare is situated slightly posterior of the outer; deeply excavated beneath the anterior edge of the cusp, the cavity tapers rapidly both anteriorly and posteriorly, terminating beneath the third denticle on the anterior process.

? $M$ element. A poorly preserved fragment of a dolabrate element occurs with the elements above and may represent the $\mathrm{M}$ element of this apparatus. The cusp is erect and has costate anterior and posterior edges; medially on the inner side the cusp is strongly inflated. A deep, steeply inclined, posterior process remnant extends from the base of the cusp bearing two tall, partially fused, pointed denticles. The antero-basal corner of the cusp is compressed and extended slightly downwards and anteriorly. The anteriorly rounded basal cavity is expanded inwards beneath the cusp, ex- tending only a short distance beneath the posterior process.

Remarks. A single sample, GGU 274747 , from the middle of the Tures $\varnothing$ Formation of Kronsprins Christian Land contains these poorly preserved and thermally altered elements. The $\mathrm{Pa}$ element differs from that of $O$. excavata, which is broadly arched and has a basal cavity which extends to the tips of the processes. The irregularity of the denticles on the anterior process, prominent apical denticle and a restricted basal cavity suggest a closer affinity to Ozarkodina hassi which occurs in samples above and below.

\section{Ozarkodina pirata Uyeno \& Barnes, 1983}

Plate 13, figs 20-23; plate 14, figs 1-8

v1979 Ozarkodina aff. O. polinclinata (Nicoll \& Rexroad); Aldridge, p. 17, pl. 2, figs 1-5.

1981 Ozarkodina n. sp. Uyeno \& Barnes, pl. 1, fig 2.

p1983 Ozarkodina pirata Uyeno \& Barnes, p. 21, figs $16,21-25$ pl. 2 , figs $12,13,19-28$, non $\mathrm{pl} .1$, fig. 17 , ?pl. 2, fig. 19 .

Holotype. Specimen number GSC 64831 a Pa element from GSC locality C-92669: figured in Uyeno \& Barnes (1983, pl. 2, fig. 12). From member I, Jupiter Formation, Anticosti Island.

Emended diagnosis. Elements with shallow restricted basal cavities. The Pa element is characterised by tall, fused denticles posterior of midlength; denticles decrease in height anteriorly and posteriorly; the basal cavity is narrow and groove-like. In lateral view closely packed but separate rectangular blocks of white matter fill the denticles of each element, their lower edges forming a sharply defined, downwardly convex trace.

Description. Refer to the description of the $\mathrm{Pa}, \mathrm{Pb}, \mathrm{M}$, $\mathrm{Sa}$ and $\mathrm{Sb}$ elements of $O$. aff. $O$. polinclinata Nicoll \& Rexroad; Aldridge (1979, pp. 17-18). Sc element. Bipennate compressed element; the narrow cusp is lenticular in cross section. The anterior process projects vertically downwards from the antero-basal corner of the cusp; its upper edge is twisted slightly towards the posterior; is long and bears four or five inwardly inclined, compressed denticles. The posterior process is broken in all specimens but bears compressed, partially fused denticles.

Remarks. The basal cavity is a narrow groove extending the length of the element. The high central denticles and lack of two or three tall denticles at the tip of the anterior process remain constant features throughout 
the range of this species (mid to late Llandovery in Greenland). Stratigraphically older forms (plate 13, figs 20-23) have a straight lower edge and slight lateral inflation occurs beneath the denticle row. Specimens from the P. celloni Biozone of Greenland most closely resemble those from Anticosti Island (Uyeno \& Barnes, 1983).

The $\mathrm{Pb}$ element of $O$. pirata from Greenland is more strongly arched and has a deeper anterior process than that of $O$. pirata by Uyeno \& Barnes $(1983$, pl. 1, fig. 17; pl. 2, fig. 19); the latter approach that of Uyeno \& Barnes (1983, pl. 1, fig. 17; pl. 2, fig. 19).

The M element of $O$. pirata and Aspelundia fluegeli are indistinguishable; that of $O$. polinclinata differs in having a much wider separation of the cusp from the denticles and a more broadly arched inner edge to the basal cavity. Rexroad \& Nicoll (1972, pl. 1, figs 35-38) illustrated specimens which appear to be morphologically intermediate between $O$. pirata and $O$. polinclinata.

Occurrence. Found in middle to upper Llandovery strata in Peary Land, Kronprins Christian Land, Wulff Land and Washington Land.

\section{Ozarkodina n. sp. A}

Plate 14, fig. 13

Description. Pa element. Carminate element with a straight lower edge and arched upper edge. The anterior process is incomplete in all specimens, deeper than the posterior process and bearing compressed, slender, needle-like, almost completely fused denticles. The apical denticle is inconspicuous, situated above the basal cavity tip. The posterior process bears sixteen to twenty needle-like, posteriorly inclined denticles which are more or less subequal in height; the process decreases in height posteriorly. The basal cavity is long and groovelike; its inner edge is slightly flared and in lower view the cavity is lenticular in outline. The basal cavity terminates just before the tip of the posterior process.

Remarks. The Pa element displays a marked difference in denticulation from other species of Ozarkodina.

Occurrence. Found only in the Odins Fjord Formation at Odin Fjord, Peary Land.
Ozarkodina n. sp. B

Plate 14, figs $14-16$

Description. Pa element. Large, slightly arched, carminate element with a prominent apical denticle, situated just to the posterior of the midpoint. The anterior processes are long and inclined slightly downwards, bearing ten to twelve completely fused, compressed denticles, which are lenticular in cross section and gradually decrease in height distally. The most proximal denticle is almost as tall as the cusp, but not as tall as its counterpart on the posterior process. The upper edge of the anterior process is straight and more steeply inclined downwards than that of the posterior process. The posterior process is shorter, though of similar form to the anterior process, bearing six to eight tall, fused denticles which decrease in height distally. Beneath the denticle row the blade is occasionally slightly inflated laterally. The cavity is only slightly expanded on the inner side and forms a narrow groove beneath the processes. The basal cavity is commonly infilled with basal material.

$M$ element. Dolabrate with a short, denticulate anticusp and longer posterior process. The cusp is broad based and lenticular in midheight cross section. The anticusp bears two to four compressed, fused denticles. The posterior process is broken in all specimens, is directed downwards and forms an angle of approximately $100^{\circ}$ with the posterior edge of the cusp. It bears compressed, partially fused denticles. The lower edge of the element is inwardly expanded beneath the cusp and posterior process. The basal cavity is shallow and narrows to a groove beneath the anticusp, terminating just before the tip.

Sa element. Alate; the cusp is broad, erect and compressed. The lateral processes form an angle of approximately $160^{\circ}$ between their lower edges. The processes are of equal length and bear five small, outwardly inclined, compressed denticles, which are fused almost to their tips. The basal cavity is slightly expanded beneath the cusp; rounded lenticular in lower view, it tapers rapidly forming an extremely narrow groove beneath the lateral processes. This cavity is shallower beneath the processes and terminates almost at their tips.

Remarks. All the elements have compressed, almost completely fused denticles and a small groove-like basal cavity. The Pa element closely resembles Ozarkodina aff. O. media Pollock, Rexroad \& Nicoll $(1970$, p. 756, pl. 113 , figs 13,14 ), but differs in having a more pronounced differentiation of the anterior and posterior processes and a more prominent apical denticle.

Similarities between the Pa elements of Ozarkodina n. sp. A, Ozarkodina n. sp. B and $O$. pirata suggest 
close morphological affinity; the M element of Ozarkodina $\mathrm{n}$. sp. B is similar to that of $O$. excavata.

Occurrence. Found only in GGU 228901 from the Odins Fjord Formation in central Peary Land.

\section{Ozarkodina n. sp. C}

Plate 14, figs 17-20

Description. Pa element. Arched carminate element; the upper edge bears compressed, posteriorly inclined, partially fused denticles, with triangular free apices. The apical denticle is inconspicuous, situated above the basal cavity, slightly anterior of the midlength of the element. The anterior process is more or less horizontal bearing five to eight denticles. The posterior process is slightly downturned bearing six to seven denticles, which are slightly larger than those of the anterior process; the lateral faces of the element are inflated beneath the denticle row. The basal cavity is inwardly expanded, the inner edge of the basal cavity is upturned beneath the apical denticle, the outer edge of the basal cavity projects downwards and slightly outwards below the inner edge. The cavity extends as a shallow groove to the midlength of the anterior process, the posterior process lacks a basal groove.

$\mathrm{Pb}$ element. Angulate, compressed element with a straight lower edge and prominent, posteriorly inclined cusp. The anterior process is approximately twice as deep as the posterior process, bearing five compressed denticles which are fused to midheight; the fourth distal denticle is twice the size of the other denticles. The posterior process bears four much smaller, compressed, peg-like denticles which are discrete, except for the most proximal which is fused to the edge of the cusp; the denticles are separated by narrow, 'u-shaped' spaces. The basal cavity is narrow and groove-like.

Sa element. Alate, compressed element; the cusp is broad and erect, its lateral edges are costate. The lateral processes are inclined slightly downwards, bear short, compressed, almost completely fused denticles. The most proximal denticles are fused to the base of the cusp. The basal cavity is extremely small; its posterior margin is upturned slightly beneath the cusp. The lower edge of the processes is poorly preserved, and it is not possible to see if a basal groove was developed.

?Sb element. A single fragment occurs with four $\mathrm{Pa}$ elements in GGU 254879 and may represent the Sb element of this apparatus. It is a compressed, modified tertiopedate element lacking a well developed posterior process. In posterior view the lower edge of this specimen is almost straight. The inwardly inclined cusp is compressed and is oval in cross section. The innerlateral process bears three compressed, tall denticles, which are outwardly inclined and fused almost to their tips. The most proximal of these denticles is much smaller than the others. The outer-lateral process is

\section{Plate 14}

Figs 1-8. Ozarkodina pirata Uyeno \& Barnes.

All specimens $\times 60$.

1 , inner-lateral view of Pa element; MGUH 17.824 from GGU 228970.

2, inner-lateral view of Pa element; MGUH 17.825 from GGU 216853.

3, inner-lateral view of Pa element (holotype); MGUH 14.056 from GGU 184125 .

4, inner-lateral view of Pb element; MGUH 14.057 from GGU 184125 (Aldridge, 1979, pl. 2, fig. 2).

5 , inner-lateral view of M element; MGUH 14.058 from GGU 184125 (Aldridge, 1979, pl. 2, fig. 5).

6, inner-lateral view of Sc element; MGUH 17.826 from GGU 228970.

7, posterior view of Sa element; MGUH 17.827 from GGU 228970.

8, posterior view of Sb element; MGUH 17.828 from GGU 228970 .

Figs 9-12. Ozarkodina n. sp. E.

All specimens from GGU 256308, × 60 .

9, inner-lateral view of Pa element; MGUH 17.829.

10 , inner-lateral view of ?M element; MGUH 17.830

11. posterior view of ?Sb element. MGUH 17.831.

12, inner-lateral view of ?Sc element: MGUH 17.832.

Fig. 13. Ozarkodina n. sp. A.

13 , inner-lateral view of $\mathrm{Pa}$ element, $\times 80$; MGUH 17.833 from GGU 254711.

Figs 14-16. Ozarkodina n. sp. B.

All specimens from GGU 228901, $\times 40$.

14, inner-lateral view of Pa element; MGUH 17.834.

15, inner-lateral view of M element; MGUH 17.835.

16, posterior view of Sa element; MGUH 17.836.

Figs 17-20. Ozarkodina n. sp. C.

All specimens from GGU $254879, \times 60$.

17, inner-lateral view of Pa element; MGUH 17.837.

18, posterior view of Sa element; MGUH 17.838.

19, inner-lateral view of $\mathrm{Pb}$ element; MGUH 17.839.

20 , inner-lateral view of ?Sc element; MGUH 17.840.

Fig. 21. Ozarkodina n. sp. D.

21 , inner-lateral view of $\mathrm{Pa}$ element, $\times 60$; MGUH 17.841 from GGU 274766. 

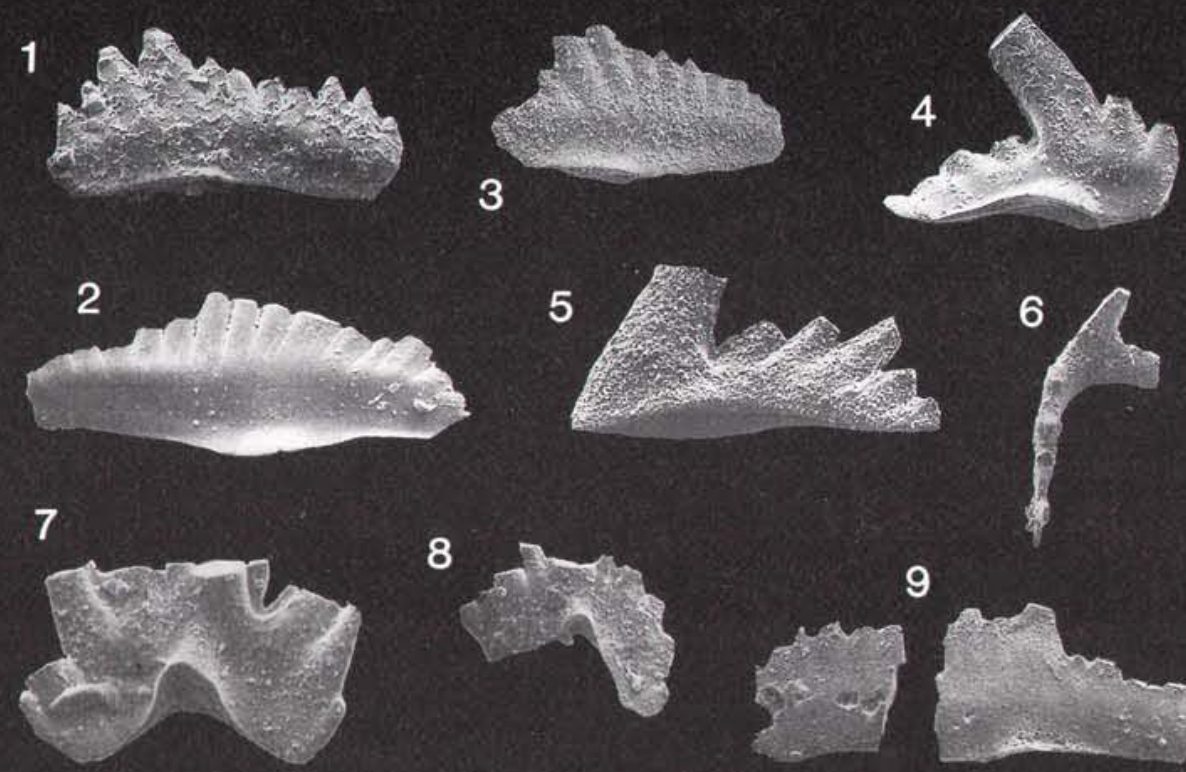

8
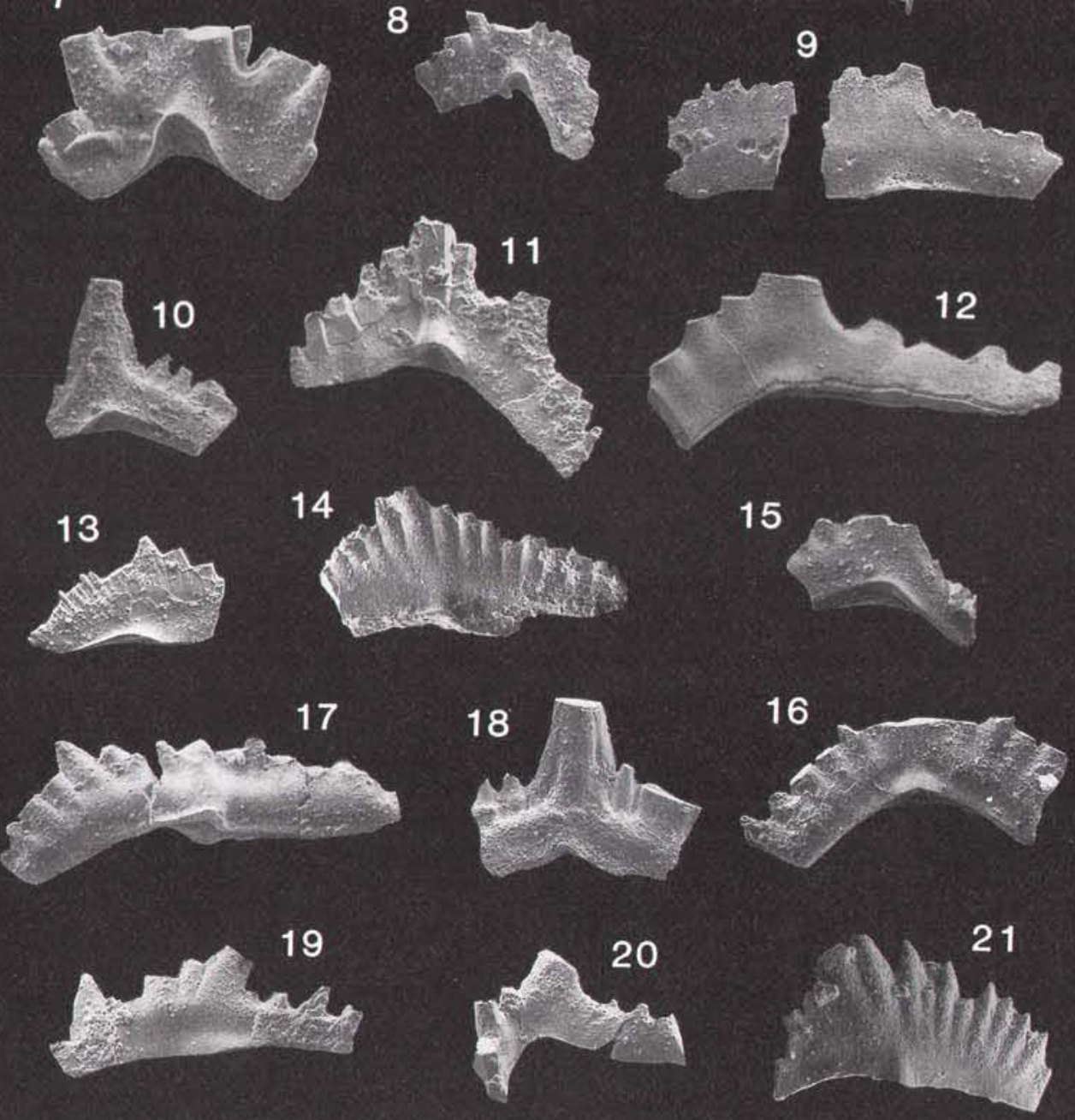
broken and bears only the fused remnants of two denticles. The posterior lower edge of the basal cavity is upturned beneath the cusp and asymmetrically inclined towards the inner-lateral process. The cavity is shallowly excavated, extending laterally as a tapering groove which terminates just before the tip of the inner process.

Sc element. Bipennate with a strongly, inwardly curved and downwardly directed anterior process. The cusp is lenticular in midheight cross section. The horizontal posterior process bears almost identical denticles to those on the posterior process of the $\mathrm{Pb}$ element. The anterior process bears up to four discrete denticles, which are circular in cross section. The basal cavity is only slightly expanded beneath the cusp, extending as a narrow groove to the tips of the processes.

Remarks. Basal cavity shape and posterior process morphology distinguish Ozarkodina n. sp. C from $O$. excavata. The apparatus of these species are closely similar in many respects and Ozarkodina n. sp. C may be a stratigraphical or geographical variant of $O$. excavata.

\section{Ozarkodina n. sp. D}

Plate 14, fig. 21

Description. Pa element. Carminate, slightly inwardly bowed element with an arched, denticulate upper edge. The inconspicuous, apical denticle is situated above the basal cavity, just posterior of midlength. The anterior process bears nine tall, compressed denticles, fused to above midheight and of variable height; the most proximal denticle is larger than the rest which tend to decrease in height distally. The denticles posterior of midlength are posteriorly inclined, those to the anterior are anteriorly inclined. The posterior process bears four denticles; the most proximal is the largest, the remaining denticles are shorter than those of the anterior process and decrease in height posteriorly. The upper edge of the posterior process is steeply inclined downwards, the lower edge less so. The symmetrical basal cavity is slightly expanded, extending to the tips of the processes as a shallowly excavated tapering groove. Inwardly the edge of the cavity beneath the apical denticle is broadly concave upwards, outwardly it is broadly concave downwards. White matter is present in all denticles, not completely filling them, but in blocks that are larger in the larger denticles and are separated by narrow gaps. The base of the white matter defines a sharp linear trace which is broadly upwardly concave at approximately the mid-depth of the blade. The highest point of this trace occurs beneath the apical denticle.
Remarks. Five $\mathrm{Pa}$ elements of this species are known from GGU 274766, from the upper Odins Fjord Formation in Kronprins Christian Land. The high central denticles and groove-like basal cavity suggest an affinity with $O$. pirata.

\section{Ozarkodina n. sp. E}

Plate 14, figs 9-12

Description. Pa element. Carminate, straight blade with a high anterior process and much lower posterior process. A prominent, though short, erect apical denticle is situated to the posterior of midlength; it has a broad base. The anterior process is approximately twice as high and longer than the posterior, bearing eight tall, erect denticles which are fused almost to their tips. The posterior process bears only four to five much shorter denticles. The basal cavity takes the form of a narrow groove extending the entire length-of the element. The inner lower edge of the cavity is flared slightly beneath the cusp; the entire lower surface is shallowly excavated. No white matter is visible due to the thermal alteration of the specimens.

?M element. Dolabrate, with a broad, compressed cusp. The anterior basal corner of the cusp is extended slightly and bears a single denticle. The posterior process is broken in all specimens, but bears triangular, discrete, compressed denticles. The inner, lower edge is upturned beneath the posterior process; it becomes strongly upwardly arched and outwardly flared beneath the posterior edge of the cusp and narrows beneath the anterior basal corner of the cusp. The cavity is deeply excavated where it is posteriorly flared, shallowing beneath the anterior basal corner of the cusp. The basal cavity extends the entire length of the element.

?Sb element. Modified tertiopedate element lacking a well developed posterior process. The tall cusp is compressed and has sharp lateral edges. The inner-lateral process is the shorter of the two and diverges less steeply than the outer process, an angle of $130^{\circ}$ being developed between their lower edges. The inner process bears five compressed, partially fused denticles, of which the most proximal is almost completely fused to the cusp; the denticles decrease in size distally; the outer process bears the remnants of six denticles. The posterior edge of the basal cavity is upturned into a narrow arch beneath the cusp and is also slightly expanded posteriorly, the cavity extends to the tips of the processes as a tapering groove.

?Sc element. Bipennate; anterior process is sharply downturned and inwardly bowed, its upper edge forming an angle of approximately $110^{\circ}$ with the edge of the 
cusp; this process bears four partially fused denticles. The posterior process diverges horizontally, its upper edge is twisted slightly outwards and bears six posteriorly inclined denticles which are fused only at their base. The basal cavity is slightly expanded beneath the cusp, extending to the tips of the processes as a narrow, shallowly excavated groove.

Remarks. These specimens form part of an Ozarkodina apparatus present in GGU 256308 although it is not

certain the ramiform elements are from the same apparatus as the $\mathrm{Pa}$ element. The proposed $\mathrm{M}$ element, in particular, bears close resemblance to that for early representatives of $O$. excavata. The Pa element has a similar deep anterior process to its counterpart in the apparatus of $O$. oldhamensis Rexroad (1967, p. 49; pl. 3 , figs 1,2 ).

Occurrence. Found only in the Melville Land Member of eastern Peary Land.

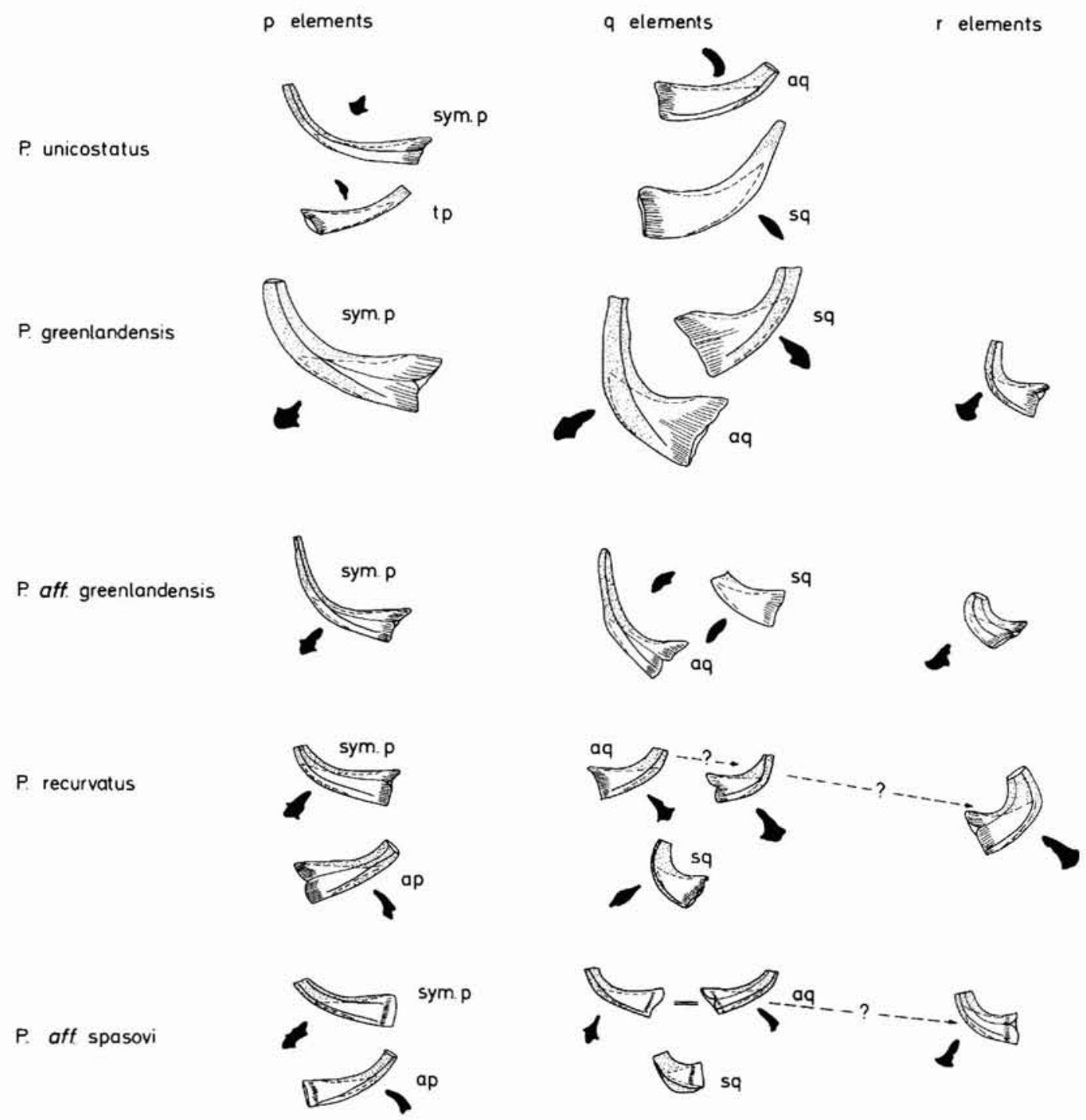

Fig. 32. Species of Panderodus illustrating distribution of white matter (stippled), outline of basal cavity and cross-section at midheight. Arrows indicate morphological transition. Camera lucida drawings $\times 25$. P. unicostatus, MGUH 14.074 (sym. p), MGUH 19.312 (tp), MGUH 19.313 (aq), MGUH 14,072 (sq). P. greenlandensis, MGUH 19.314 (sym. p), MGUH 19.315 (aq), MGUH 19.316 (sq), MGUH 19.317 (r). P aff. P. greenlandensis, MGUH 19.318 (sym. p), MGUH 19.319 (aq), MGUH 19.320 (sq), MGUH 19.32 (r). P. recurvatus, MGUH 17.922 (sym. p), MGUH 17.923 (ap), MGUH 19.322 (aq), MGUH 19.323 (sq), MGUH 17.928 (aq), MGUH 17.931 (r). P. aff. P. spasovi, MGUH 19.324 (sym. p), MGUH 19.325 (ap), MGUH 17.913 (?tp), MGUH $17.920(\mathrm{sq})$, MGUH 17.916 (r), MGUH 17.918 (aq). 
Genus Panderodus Ethington, 1959

Type species. Paltodus unicostatus Branson \& Mehl, 1933a, p. 42.

Diagnosis. Refer to the diagnosis in Sweet (1979, p. 62).

Remarks. Sweet (1979) and Barnes et al. (1979) working with Ordovician material have both proposed nomenclatural schemes for the constituent elements of Panderodus, and these are summarised in fig. 28 . Herein it is recognised to contain a slender sym. p, an aq and a broad, laterally compressed sq element; no $r$ element has been recognised for $P$. unicostatus though one is known in other species. Additional rare elements also occur, such as tp (equivalent to the tortiform element of Sweet, 1979) and a serrate aq element (previously described as $P$. unicostatus serratus of Rexroad, 1967). The latter has recently been considered a minor reiterative variant (Rexroad et al., 1978, p. 11).

L. Jeppsson (Lund, personal communication) is currently reviewing Panderodus and consequently this genus is dealt with only briefly herein. Element homologies are summarised in fig. 32 .

\section{Panderodus cf. P. feulneri (Glenister, 1957) Plate 15, figs 9-14 \\ cf.v 1957 Paltodus feulneri Glenister, p. 728, pl. 85, \\ cf. 1979 Panderodus feulneri (Glenister); Sweet, p. 64, pl. 7, figs $1,8,11-14,17,18,22$.}

Description. sym. p element. Squat, broad-based cone with a short base and long, erect cusp. The basal margin is straight, and centrally notched on both sides. Both lateral faces are inflated below the furrow, which ex- tends to the apex of the cusp; the inner furrow bears a narrow groove centrally. The lower edge of both furrows is costate, the costae extending from the basal margin to the apex. A zone of faint basal wrinkles passes around the base of the cone, and the entire basal surface is excavated; the basal cavity terminates at the base of the cusp, close to the lower margin. White matter is concentrated into the tip of the cusp, diffuse white matter may, in larger specimens, extend a short distance along the upper and lower margins of the base.

ap element. Differs from the sym. $\mathrm{p}$ element only in the asymmetrical disposition of the inner lower-lateral costa.

sq element. Laterally compressed, the base is long and broad, the keeled upper and narrower lower margins are evenly recurved; the basal margin is straight and more or less flat, with a centrally situated, prominent, basal notch on either side. The inner furrow bears a deep, narrow groove just above the midline of the furrow; this is absent in the outer furrow. A prominent costa originates just apical of the basal wrinkles, at the midpoint of the lower face; apically it migrates upwards, forming the lower edge of the furrow, from base midheight. A zone of coarse, basal wrinkles passes around the base; the entire basal surface is excavated, and basal cavity outline and white matter distribution are similar to those of the sym. p element.

$r$ element. Squat, strongly recurved cone, with a broad base and a narrow, short cusp. This element is bilaterally symmetrical in all features except the development of the furrow. The narrow upper and broadly rounded, lower margins are strongly curved apically, the upper extending basally as a short heel. Both lateral faces bear a prominent costa close to, and parallel with, the lower margin; these originate at the apical edge of the basal wrinkles and extend to the apex. A narrow furrow extends to the apex on the inner face. The basal

\section{Plate 15}

Figs 1-8. Panderodus greenlandensis n. sp.

All specimens from GGU $184125, \times 60$.

1, outer-lateral view of ?sq element; MGUH 14.077 (Aldridge, 1979. pl. 2, fig. 21).

2, inner-lateral view of ?sq element; MGUH 14.077 (Aldridge, 1979, pl. 2, fig. 26).

3 , inner-lateral view of sym. p element; MGUH 14.075 (Aldridge, 1979, pl. 2, fig. 23).

4, outer-lateral view of sym. p element; MGUH 14.075 (Aldridge, 1979, pl. 2, fig. 28).

5 , inner-lateral view of aq element; MGUH 14.076 (Aldridge, 1979, pl. 2, fig. 24).

6, outer-lateral view of aq element; MGUH 14.076 (Aldridge, 1979, pl. 2, fig. 27).
7, inner-lateral view of $\mathrm{r}$ element; MGUH 14.078 (Aldridge, 1979 , pl. 2, fig. 29).

8, outer-lateral view of $\mathrm{r}$ element; MGUH 14.078 (Aldridge, 1979, pl. 2, fig. 30).

Figs 9-14. Panderodus cf. P. feulneri (Glenister). All specimens from GGU $216835 ; \times 40$.

9,10 , outer and inner-lateral view of sym. p. element; MGUH 17.901 .

11,12 , outer and inner-lateral view of sq element; MGUH 17.902 .

13, 14. inner and outer-lateral view of $r$ element; MGUH 17.903 . 


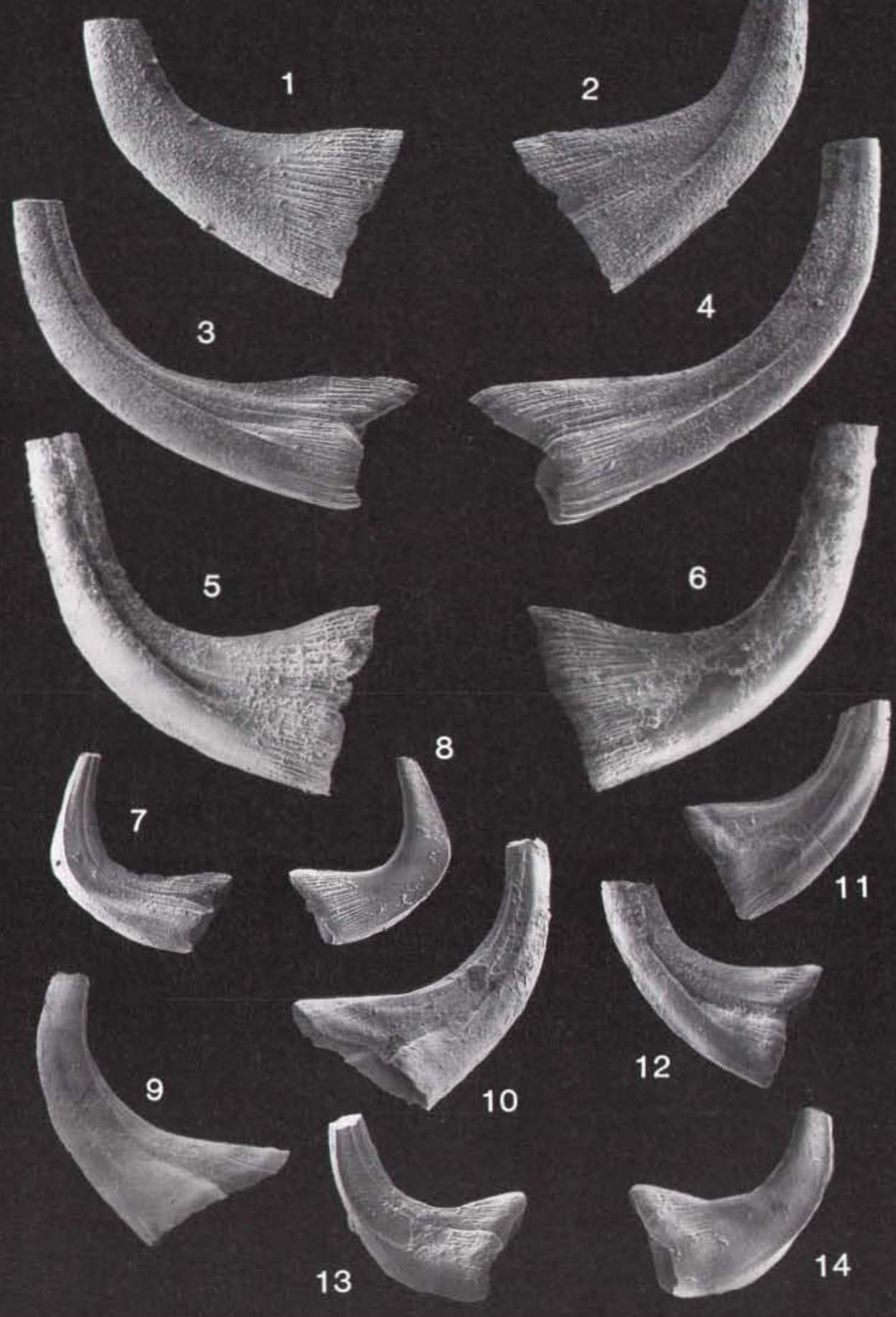


margin is straight bearing a prominent central basal notch on the inner face. A zone of basal wrinkles passes around the base; the entire basal surface is deeply excavated. The basal cavity and white matter distribution are as described for the other elements.

Remarks. This apparatus contains stout, broad based cones with prominent lateral costae. The sym. $p$ and $r$ elements compare closely with the costate falciform and the arcuatiform elements of $P$. feulneri sensu Sweet (1979). The latter differ in being taller and more slender. The $P$. feulneri apparatus contains no apparent sq element.

Occurrence. Found rarely in lower-middle Llandovery strata in Peary Land, Washington Land, Wulff Land and J. P. Koch Fjord.

Panderodus greenlandensis $\mathrm{n}$. $\mathrm{sp}$.

Fig. 33; plate 15, figs 1-8

vp1972 Panderodus cf. p. gracilis (Branson \& Mehl); Aldridge, p. 203, pl. 9, fig. 13; non fig. 12.

1977 Panderodus recurvatus; Liebe \& Rexroad, pl. 2, fig. 22.

p1978 Panderodus serratus; Miller, pl. 1, figs 5, 8 only.

1979 Panderodus spp. Aldridge, pl. 2, figs 23-30.

Name derivation. After Greenland.

Type material. Specimens from the Lower Visby Beds, Gotland. Locality Nyhamn 1 (CK 4639 0582, in Laufeld, 1974), sample G79-217b LJ from approximately $2.5 \mathrm{~m}$ above sea level and $4 \mathrm{~m}$ from the shore line (fig. $33)$.
Diagnosis. Elements sym. p, aq, sq and $\mathrm{r}$ are all typically robust, broad and have well developed, broadly rounded lateral costae and a deep prominent furrow, white matter is restricted to the base of the cusp and does not extend to the apex.

Description. sym. p element. Robust, bilaterally symmetrical cone with a broad base and cusp, approximately equal in length. The cusp is steeply proclined to erect and curved from its base. The keeled upper margin extends basally forming a flattened heel. The basal margin is straight beneath the lower-lateral faces and inclined beneath the heel. A prominent basal notch is situated centrally on the inner margin of the base. Both lateral faces are inflated and each bears a single costa, which originates at a central point close to the apical edge of the basal wrinkles, both extend to the apex though migrate slightly towards the upper margin. The inner costa forms the steep lower face of the furrow between midheight of the base and the point of maximum curvature of the upper margin. The furrow tapers apically, terminating at the base of the cusp. Within the furrow is a deep narrow groove with slightly raised edges, this extends from the basal notch to the apex. Above the furrow the inner face of the keel may bear fine, longitudinal microstriations. The outer face of the element bears a shallow furrow, this lacks the central groove; basally the outer furrow is deeper and narrower than the inner; it terminates in the lower third of the cusp. A zone of basal wrinkles, approximately oneeighth of the height of the element, passes around the base of all elements in this apparatus. This zone may extend apically in the vicinity of the lateral furrows,

Fig. 33. Type suite of Panderodus greenlandensis from the Lower Visby Beds, Gotland, Sweden. Donated by L. Jeppsson (Univ. of Lund) 1-5, paratype MGUH 19.326.

1 , inner lateral view, $\times 50$ sym. p element;

2 , outer lateral view, $\times 50$ sym. p element;

3 , transmitted light showing white matter distribution, $\times 76$;

4 , lower part of base (inner lateral, $\times 95$ );

5 , lower part of base (outer lateral) $\times 95$;

6-10, paratype, 6, MGUH 19.327, inner lateral view, sq element;

7, outer lateral view, sq element;

8 , lower part of base (inner lateral), $\times 95$;

9 , transmitted light showing white matter distribution, $\times 76$;

10 , lower part of base (outer lateral), $\times 95$;

11-15, holotype, MGUH 19.328;

11 , inner lateral view, aq element;

12 , outer lateral view, aq element;

13 , transmitted light showing white matter distribution $\times 76$;

14 , lower part of base (inner lateral, $\times 95$;

15 , lower part of base (outer lateral), $\times 95$. 
individual wrinkles vary in height and width randomly. The entire basal surface is completely excavated, basal cavity outline and white matter distribution are illustrated for all the elements in fig. 32 .

aq element. Recurved, laterally compressed element, broad-based with a narrow proclined cusp. The inner face bears a broadly rounded costa close to its lower margin, this extends from the apical edge of the basal wrinkles to the apex. Medially a broad, shallow, apically tapering furrow terminates at the base of the cusp. The outer face is broadly convex and develops a rounded costa and furrow close to its upper margin.

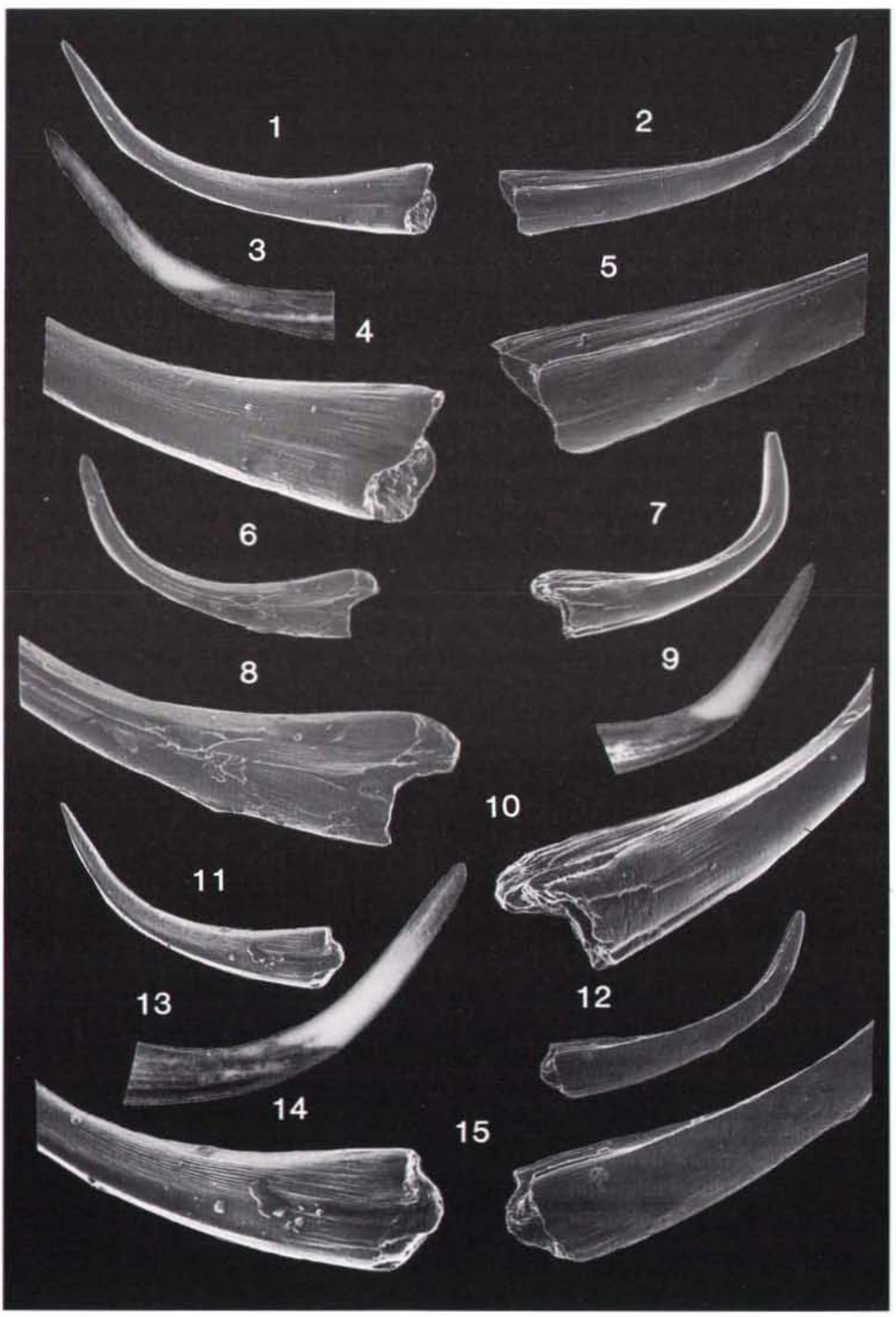


sq element. Broader and more posteriorly curved than the sym. p element. The lower and upper margins are sharp with a low keel occasionally developed along the lower margin. A broadly rounded costa is situated centrally on each lateral face extending from the apical edge of the basal wrinkles to the apex. The basal margin is straight with no heel, a basal notch is barely distinguishable, at the centre of the inner edge. The entire basal surface is excavated.

$r$ element. Short, relatively slender element with a steeply reclined to recurved cusp. Base and cusp are approximately equal in length, the upper margin of the base may be keeled, but is more commonly only sharp, maximum curvature occurring at the base of the cusp. The lower margin of the base is rounded and more or less straight. Inwardly a prominent, sharp costa extends apically from a point just above the base, running close and subparallel to the lower margin; the costa decreases in height apically. Above the costa the remainder of the face is shallowly concave, divided at midline by a shallow furrow with central groove. The furrow terminates at the base of the cusp, its central groove extends along the midline from a basal notch to the apex. The outer face has a prominent longitudinal costa which may be situated as that on the inner face of the aq element or may be positioned slightly towards the midline, in which case it migrates towards the anterior edge of the cusp from above the maximum curvature. Above the costa the outer face is smooth and shallowly concave with both furrow and basal notch absent. The basal margin is straight.

Remarks. The type locality (and hence the type material for this species) has been selected in Gotland where preservation is far superior to that of the Greenland material and where further material can be collected as required. Lennart Jeppsson (Lund) kindly supplied the type material (fig 33). Several samples from Washington Land (particularly GGU 216719) contain elements similar to those placed in the apparatus of $P$. greenlandensis. They are taller, however, and more slender, developing thin walls to the basal cavity. These elements may represent an ecological or geographical variant of $P$. greenlandensis, and until larger collections are available they are referred to $P$. aff. $P$. greenlandensis (plate 5, figs 18-23). Many specimens of $P$. greenlandensis are more robust and larger than those from Gotland.

\section{Panderodus recurvatus (Rhodes, 1953)}

Plate 16, figs 1-11

v*1953 Paltodus recurvatus Rhodes, p. 297, pl. 23, figs $219,220$.

1977 Panderodus recurvatus; Barrick, p. 54, pl. 3, figs $3,4,7-12$ (see for further synonymy).

\section{Plate 16}

Figs 1-11. Panderodus recurvatus (Rhodes).

All specimens from GGU 216853, $\times 60$ unless otherwise stated.

1, inner-lateral view of sym. p element; MGUH 17.922.

2 , outer-lateral view of sym. p element; MGUH 17.923.

3 , microstriations on inner-lateral face of aq element, $\times 350$; MGUH 17.929

4, inner-lateral view of aq element, slender morphotype; MGUH 17.925 .

5 , inner-lateral view of aq element, slender morphotype; MGUH 17.926 .

6, lateral view of sq element; MGUH 17.927.

7 , inner-lateral view of aq - $\mathrm{r}$ intermediate element; MGUH 17.928 .

8, lateral view of aq element, broad morphotype; MGUH 17.929.

9. microstriations on the inner face of aq element, slender morphotype, $\times$ 340; MGUH 17.926.

10, inner-lateral view of $\mathrm{r}$ element; MGUH 17.931.

11, outer-lateral view of $\mathrm{r}$ element; MGUH 17.932.

Figs 12-15. Panderodus spp. aff. P. recurvatus (Rhodes). All specimens $\times 60$.

12, inner-lateral view of aq element; MGUH 17.933 from GGU 216837.

13, inner-lateral view of sym. p element; MGUH 17.934 from GGU 216852.

14, outer-lateral view of sym. p element; MGUH 17.935 from GGU 82687.

15 , outer-lateral view of $\mathrm{r}$ element; MGUH 17.936 from GGU 216852.

Figs 16-21. Panderodus sp. A.

All specimens from GGU 256337 unless otherwise stated, $\times$ 60 .

16,17 , inner and outer-lateral view of sym. p element; MGUH 17.937.

18, outer-lateral view of ap element; MGUH 17.938 from GGU 274724.

19, inner-lateral view of ap element; MGUH 17.939 from GGU 274724.

20, inner-lateral view of sq element; MGUH 17.940.

21 , inner-lateral view of sq element; MGUH 17.941.

Fig. 22. Panderodus sp. B.

22 , outer-lateral view of sym. p element, $\times 60$; MGUH 17.942 from GGU 274724.

Figs 23, 24. Panderodus sp. C.

23 , inner-lateral view of $\mathrm{r}$ element, $\times 60$; MGUH 17.943 from GGU 82687.

24 , outer-lateral view of r element, $\times 60$; MGUH 17.944 from GGU 216835. 


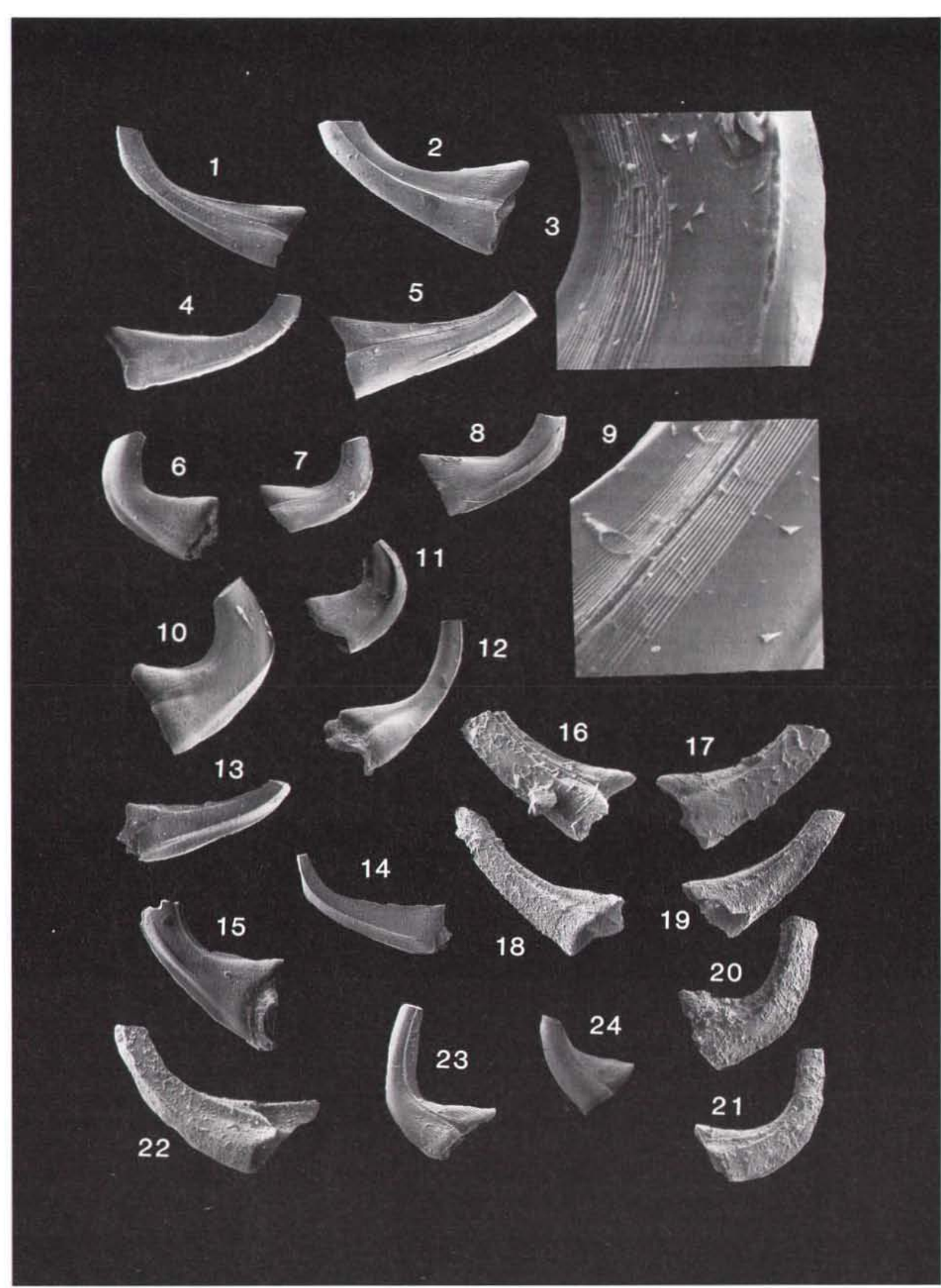


Holotype. Paltodus recurvatus Rhodes 1953, p. 297.

Emended diagnosis: Apparatus quadrimembrate comprising highly recurved laterally compressed sym. p, aq, sq and $\mathrm{r}$ elements.

Description. sym. p element: Refer to Barrick's (1977, p. 54) description of the Sa element; the Greenland specimens differ little. Pre-P. celloni Biozone examples are slightly longer and slender with a slightly more rounded cross section.

aq element. As noted by Barrick (1977, p. 55) an unusual symmetry imbalance occurs within this element. The difference occurs in the location of the furrow; the two elements figured (plate 16 , figs 4,5 ) have the furrow on either the same or the opposite face to the lower lateral costa. Slender to broad, short, asymmetrical, strongly compressed cone. The base is slightly longer than the cusp which is erect to recurved. The upper margin of the base is straight and sharp. Towards the top of the base a low keel is developed, which extends to the apex. The lower margin is keeled and evenly recurved. The basal margin is straight, a prominent basal notch is located on the inner, basal margin, onethird the distance from the upper-basal corner. The inner face bears a prominent costa close to its lower edge; this originates at the base midheight and runs subparallel to the lower margin, migrating to the junction of lateral and upper edges, just above the maximum curvature of the cusp. Above the costa the face is shallowly concave, divided into narrow upper and broad lower faces by a narrow ' $v$-shaped' groove, which extends from the basal notch to the apex, running subparallel to the midline. The groove is flanked by a narrow zone of oblique microstriations, visible only on the scanning electron microscope (plate 16 , figs 3,9 ). The outer face is gently convex and may have a short, longitudinal depression close to its centre. The upper and lower keels appear more prominent when viewed from the outer side.

sq element. Highly compressed cone, with keeled upper and lower margins. Base and cusp are subequal in length, the latter erect to recurved. The upper margin of the base is more or less straight with maximum curvature at the base of the cusp; the upper-basal corner is an acute angle. The lower margin is evenly curved from the lower-basal corner, maximum curvature occurring concurrently with that on the upper margin. The lateral faces are virtually identical and may or may not possess a prominent costa just below midlength. This originates at a point one-quarter the distance from the lower-basal corner extending to the apex and running subparallel to the lower margin. The inner face bears a narrow in- conspicuous groove in a similar position to that on the aq element.

$r$ element. Short, highly curved and commonly inwardly twisted element. The base and cusp are short and subequal in length; the cusp is strongly recurved. The upper margin of the base bears a keel apical of the zone of basal wrinkles. The lower margin is narrowly rounded and evenly curved for two-thirds of its length; above this it is sharply recurved. The basal margin is more or less straight with an inner-basal notch one-third of its length from the upper-basal corner. The area of the basal wrinkles is slightly laterally inflated, and above this the cone is highly compressed. The inner face bears a low costa close to its lower margin, originating at the apical edge of the basal wrinkles, migrating to the junction of lateral and anterior faces at the base of the cusp and extending along this to the apex. Above the costa the face is shallowly concave; a narrow, inconspicuous groove is located close to its upper edge extending from the basal notch to the apex. A shallow furrow may extend obliquely from the basal notch, terminating just above the zone of basal wrinkles. The outer face also bears a prominent costa, close to its lower margin. This is situated above that on the inner face and does not migrate. The remainder of the face is shallowly concave.

Remarks. This apparatus comprises small, strongly compressed, highly recurved elements, which have prominent lateral costae, a shallow furrow, and typically very fine basal wrinkles. A morphological transition occurs from sym. p-aq-r with the elements becoming progressively more asymmetrical, broader, shorter and more recurved. The sq element is strongly compressed, bilaterally symmetrical and is readily homologised with its counterpart in the apparatus of $P$. greenlandensis. In the $P$. recurvatus apparatus this element does not form an integral part of the sym. p-aq-r transition series.

The $\mathrm{q}$ and $\mathrm{r}$ elements of $P$. recurvatus are similar to their counterparts in the $P$. aff. $P$. spasovi apparatus, differing in the even upward curvature of the lower edge; the $p$ elements are characteristic in the apparatuses of both species. Barrick (1977) noted that P. panderi Stauffer (1940), a Middle Devonian species, was similar to elements within the $P$. recurvatus apparatus. $P$. panderi (Stauffer) described by Sweet (1979) from the upper Ordovician possesses elements which are less markedly recurved and bear more robust, prominent lateral costae.

The phylogeny of $P$. recurvatus is unclear; its apparatus plan has closer affinity to that of $P$. greenlandensis than to $P$. unicostatus. 
Occurrence. P. recurvatus ranges from mid to late Llandovery in the majority of Greenland sections. It was previously only recorded in post-Pterospathodus celloni Biozone strata (Barrick, 1977).

\section{Panderodus spp. aff. P. recurvatus Rhodes, 1953 Plate 16, figs $12-15$}

Description. A suite of elements within the Greenland collections occur singly or in low numbers and are similar in morphology to $P$. recurvatus. They are typically strongly recurved from the base of the cusp, compressed an bear lateral costae. These elements are from more than one species and the more common representatives are illustrated. Occurrences and element abundances are recorded in Appendix 1.

\section{Panderodus aff. P. spasovi Drygant, 1974c}

Plate 17, figs 14-24

aff. 1974c Panderodus spasovi Drygant, p. 66, pl. 1, figs 1-3.

Description. sym. p element. Strongly compressed, base long, cusp short and steeply proclined. The upper margin of the base is sharp and more or less straight, concave in larger specimens (plate 17, fig. 14). The lower margin is straight and develops a low keel. The inner face bears a longitudinal costa which runs subparallel to the lower margin, extending from close to the lowerbasal corner to the apex. The face is shallowly concave from the costa to the upper edge, bearing a shallow, narrow furrow above the midline. The furrow extends apically from an inconspicuous basal notch, and terminates below midheight of the base. A narrow groove passes centrally through the furrow, subparallel to the upper margin to the apex. A narrow zone of oblique microstriations is present adjacent to the groove on the p elements, but has not been seen on the other elements. The outer face bears two longitudinal costae situated either side of the midline. Both originate at the apical edge of the basal wrinkles, curve posteriorly upwards and converge gradually. Basal cavity outline, white matter distribution and zone of basal wrinkles are similar for all elements. The basal wrinkles are weakly developed and are separated by deep grooves, they pass around the cone, parallel to, but not extending to the basal margin. The entire basal surface is excavated. White matter is restricted to the tip and basal edges.

?tp element. Extremely rare specimens with a broad base and commonly broken cusp. The upper margin of the base is sharp and slightly concave downwards; bas- ally extended as a short, acute angled heel. The lower margin is more or less straight, with a low keel. The basal margin is concave apically with an inconspicuous basal notch situated close to the midpoint on the inner side. The inner face is shallowly concave and bears a narrow median furrow which extends from the basal notch to the apex. A deep narrow groove is divorced from the furrow, situated extremely close to the upper margin of the base. The outer face differs from that of the ap element in being slightly more compressed.

aq element. Morphologically transitional from the sym. p element. The keeled upper margin and narrowly rounded lower margin recurve sharply at the base of the cusp. The basal margin is broad, equivalent in width to half the height of the base; a basal notch is situated centrally on the inner side. Laterally each face bears a single longitudinal costa close to and running subparallel with the lower margin. On the inner side the costa extends from the base to the apex, on the outer side from a point just above the apical edge of the zone of the basal wrinkles to the apex. The inner face is shallowly concave to the upper edge, a deep narrow groove running from the basal notch, migrating across the base towards the upper edge and continuing close to and subparallel to the posterior margin of the cusp. The outer face is smooth and shallowly concave to its upper margin.

sq element. Small, highly compressed, strongly recurved element. Characterised by a short, broad base and slender cusp. The upper and lower margins are sharp and evenly curved. The lower margin bears a keel which increases in height towards base midheight. The lateral faces are smooth and broadly convex, typically developing a narrow zone of basal wrinkles; the entire basal surface is excavated.

$r$ element. Morphologically transitional from the aq element, differing only in being shorter and more recurved; the cusp is more or less erect. The basal margin is narrower and not as sharply concave in the inner inflated section of the basal cavity (plate 17, fig. 19).

Remarks. Elements are distinguished from those of $P$. recurvatus by their lateral compression, basal outline, less sharply recurved cusp, and the band of basal wrinkles which does not extend to the basal margin. The sym. p element differs from that figured by Drygant (1974c), the holotype of $P$. spasovi, in the inclination of the lower margin and the ornament of the outer face. The Greenland specimens are similar to those figured by Barrick (1977) as the Sb element (particularly specimen SUI 42461, pl. 3, fig. 18). The remaining elements, placed in the apparatus of $P$. spasovi? by Barrick, differ from those from Greenland. Whether Barrick's speci- 
mens of $P$. spasovi? and the Greenland specimens represent variants of one species is unknown. The elements figured by Drygant are clearly part of a separate apparatus. The apparatus structure (with generally similar elements and common co-occurrence within the upper $P$. celloni and $P$. amorphognathoides Biozones) suggests a close relationship between $P$. recurvatus and $P$. aff. $P$. spasovi. $P$. recurvatus is first found in mid Llandovery strata throughout Greenland, and it is possible that $P$. aff. P. spasovi is a descendant.

Occurrence. In all sections across North Greenland.

\section{Panderodus unicostatus (Branson \& Mehl, 1933a)}

Plate 17 , figs $1-7$

*1933a Paltodus unicostatus Branson \& Mehl, p. 42, pl. 3, fig. 4 .

1933a Paltodus simplex; Branson \& Mehl, p. 42, pl. 3, fig. 3.

1953 Paltodus acostatus; Rhodes, p. 237, pl. 21, figs 111-112; pl. 22, figs 163-164; pl. 23 , figs $212-213$.

p1953 Paltodus unicostatus; Rhodes, p. 298, pl. 23, figs $214-216$ only.

1969 Panderodus unicostatus unicostatus; Nicoll \& Rexroad, p. 55, pl. 7, figs 29, 30 (see for further synonymy).

1969 Panderodus simplex; Nicoll \& Rexroad, p. 54, pl. 7, fig. 28 (see for further synonymy).

1971 Panderodus simplex; Rexroad \& Craig, p. 697, pl. 81 , figs $35-40$.

1971 Panderodus gracilis; Rexroad \& Craig, p. 695, pl. 81, figs 28, 29.

1971 Panderodus unicostatus; Rexroad \& Craig, p. 697 , pl. 81 , figs $30-34$.
1971 Panderodus n.sp. Rexroad \& Craig, p. 698, pl. 81 , figs 26,27 .

?1975 Panderodus serratus; Cooper, p. 993, pl. 1, figs $3-5,7-9,13,14,23$.

1976 Panderodus unicostatus; Cooper, p. 213, pl. 1, figs $1-7,22$ (see for further synonymy).

1977 Panderodus unicostatus; Barrick, p. 56, pl. 3, figs $1,2,5,6$.

Holotype. Paltodus unicostatus Branson \& Mehl, 1933a, p. 42 , pl. 3 , fig. 3 from the Brassfield Formation, Lithium, Missouri.

Diagnosis. Refer to Barrick (1977, p. 56).

Description. All the elements of $P$. unicostatus have been described previously except the tp element (see synonymy).

tp element. Slender cone with a long base and short proclined cusp. The keeled upper margin of the base is more or less straight, extended basally as a prominent heel; the lower margin narrow and rounded. Strongly, laterally compressed the cusp is twisted inwardly with respect to the base. On the inner side a narrow furrow extends from close to the upper-basal corner to the base of the cusp, the outer face is shallowly convex lacking a furrow or costae. A low zone of basal wrinkles passes around the element. The basal surface is entirely excavated, white matter is restricted to the apex of the cusp.

Remarks. Few differences can be detected between $P$. gracilis Branson \& Mehl as described by McCracken \& Barnes (1981) and P. unicostatus. The elements of the latter are slightly more recurved, the lateral costae are

\section{Plate 17}

Figs 1-7. Panderodus unicostatus Branson \& Mehl. All specimens from GGU $184125, \times 60$.

1, 2, outer and inner-lateral view of aq element; MGUH 14.074 .

3,4 , inner and outer-lateral view of sym. p element; MGUH 14.073 .

5 , inner-lateral view of tp element; MGUH 17.904

6,7 , outer and inner-lateral view of sq element; $\mathrm{MGUH}$ 14.072 .

Figs 8-13. Panderodus aff. P. unicostatus (Branson \& Mehl). All specimens from GGU 216719, × 60 .

8, outer-lateral view of sym. p element; MGUH 17.905.

9. inner-lateral view of sym. p element; MGUH 17.906.

10, upper view of sym. p element; MGUH 17.907.

11, outer-lateral view of aq element; MGUH 17.908.

12. inner-lateral view of aq element; MGUH 17.909.

13. lateral view of sq element; MGUH 17.910.

Figs 14-24. Panderodus aff. P. spasovi Drygant. All specimens $\times 60$.
14, outer-lateral view of sym. p element: MGUH 17.911 from GGU 82687.

15 , inner-lateral view of sym. p element; MGUH 17.912 from GGU 216852.

16, inner-lateral view of ?tp element: MGUH 17.913 from GGU 82687.

17, outer-lateral view of aq element, slender morphotype; MGUH 17.914 from GGU 216773.

18, inner-lateral view of aq element, slender morphotype; MGUH 17.915 from GGU 216773.

19. inner-lateral view of $\mathrm{r}$ element; MGUH 17.916 from GGU 216773.

20, outer-lateral view of r element; MGUH 17.917 from GGU 216773.

21, outer-lateral view of aq element, broad morphotype element: MGUH 17.918 from GGU 216773.

22 . inner-lateral view of aq element, broad morphotype element: MGUH 17.919 from GGU 216773.

23. outer-lateral view of sq element; MGUH 17.920 from GGU 216852.

24, inner-lateral view of sq element; MGUH 17.921 from GGU 82687. 


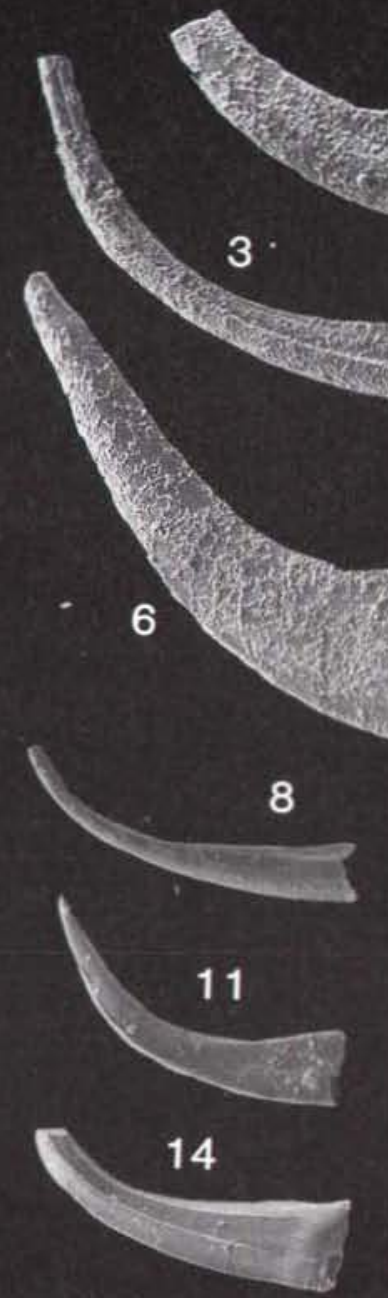

\section{1}

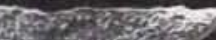

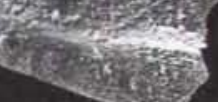
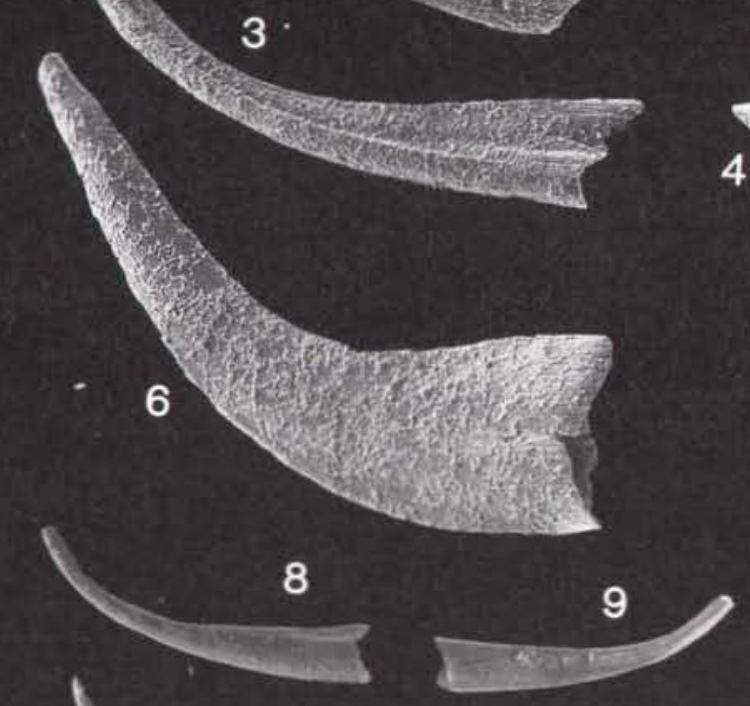

4

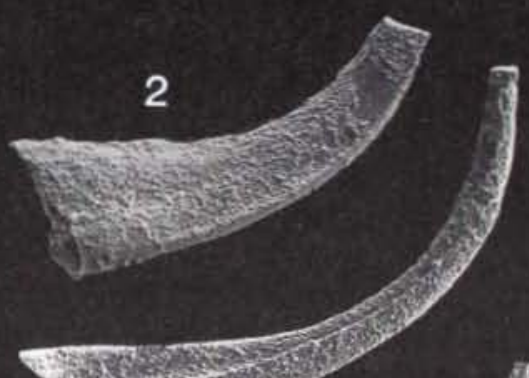

Don

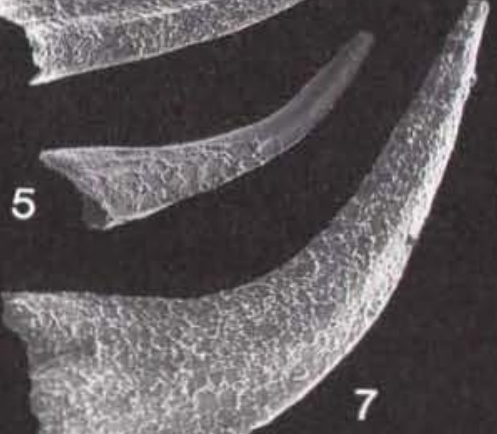

17

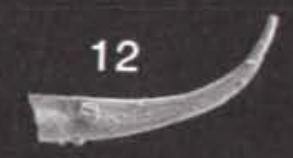

10

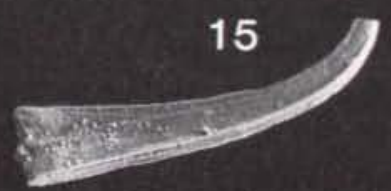

13
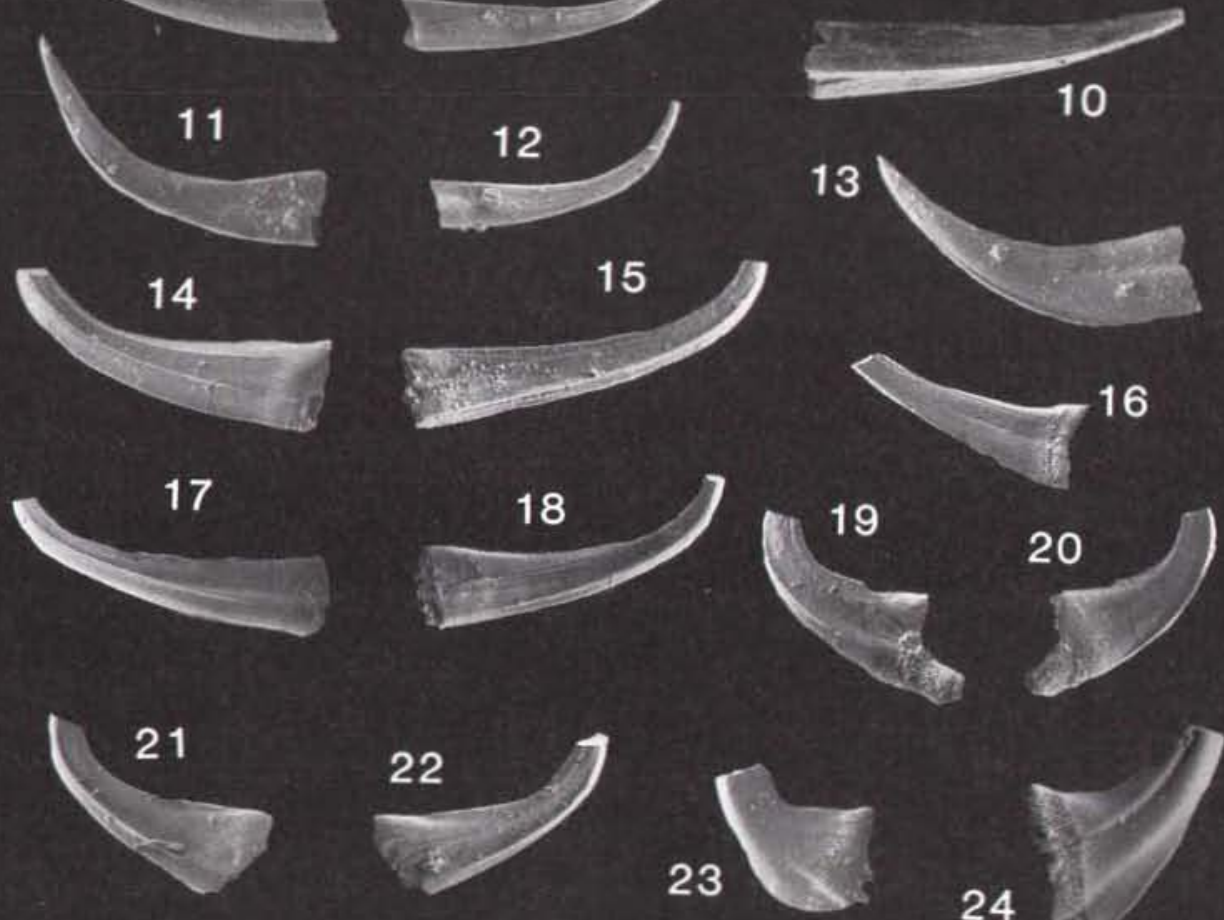
less prominent and the sq element is more slender. McCracken \& Barnes (1981) noted that the elements of P. gracilis were more variable; Lennart Jeppsson (Lund, personal communication) regards these species as synonymous. I have not studied relevant holotypes and all specimens are referred to $P$. unicostatus, the name more commonly used by Silurian workers.

Cooper (1975) distinguished P. serratus only by the presence of an additional upwardly serrate (aq) element in its apparatus. This element may be a minor reiterative variant within the $P$. unicostatus apparatus and consequently $P$. serratus is cited questionably in synonymy.

Occurrence. Found throughout North Greenland.

\author{
Panderodus aff. P. unicostatus (Branson \& \\ Mehl, 1933a) \\ Plate 17, figs $8-13$
}

aff.1933a Paltodus unicostatus Branson \& Mehl, p. 42, pl. 3, fig. 3.

aff.1933a Paltodus simplex Branson \& Mehl, p. 42, pl. 3, fig. 4.

aff. 1976 Panderodus unicostatus; Cooper, p. 213, pl. 1, figs $1-7,22$.

Description. sym. $p$ element. This thin walled element differs from that of $P$. unicostatus in having a triangular, midheight cross section and prominent lateral costae which extend from the basal margin to the apex. White matter is restricted to the tip of the cusp, and a low zone of weak basal wrinkles occurs around each element. This zone is barely visible without the use of the scanning electron microscope.

aq element. Morphologically transitional from the sym. p element. The inner face is similar to that of the sym. p element, but the costa is less prominent and does not extend to the basal margin, there is no central groove. The shallowly concave outer face has a costa close to and subparallel with the lower margin extending from the basal margin to the apex. A shallow longitudinal depression may be located centrally at the base.

$s q$ element. Biconvex, gently curving, laterally compressed, keeled element, the lateral faces are smooth, the inner bears a shallow, longitudinal furrow, which does not extend beyond the midheight of the base.

Remarks. This apparatus comprises slender, thin walled, laterally costate elements. In many respects it is similar to elements previously described as Coelocerodontus tetragonus Ethington, but differs in the shape of its basal cavity and white matter distribution. The remaining elements are typically much thinner walled and more slender than their counterparts in $P$. unicostatus. Nowlan \& Barnes (1981, p. 16, pl. 6, figs 20, 23, 27) described similar elements as $P$. gracilis; however, the costae of their sym. pelement do not extend to the basal margin. With the current geographically and stratigraphically restricted samples, it is difficult to assess whether this apparatus represents a new species or a localised ecological or geographical variant of $P$. unicostatus.

Occurrence. Found in middle Llandovery strata in Washington Land. Particularly common in GGU 216724 .

\section{Panderodus sp. A \\ Plate 16, figs 16-21}

Remarks. These specimens are mainly fragments of sym. p, aq and sq elements, and it is uncertain whether they constitute a single multi-element species. The sym. p element differs from that of Panderodus greenlandensis in having a much narrower base and a complex inner furrow; the sq element is similar though more strongly compressed, the furrow on each of its lateral faces is narrower. The sq element of this apparatus suggests an affinity with $P$. greenlandensis.

Occurrence. Found in the Turesø Formation of Peary Land.

\section{Panderodus sp. B}

Plate 16, fig. 22

Remarks. This species is known only from its fragmented sym. p element and is found only in the Tures $\emptyset$ Formation of central Peary Land. Its robust nature, deep lateral furrows, prominent costae and basally extended keel suggest an affinity with $P$. greenlandensis. Only two specimens are recorded.

\section{Panderodus sp. C}

Plate 16, figs 23, 24

Remarks. Rare specimens of this taxon are found in middle to upper Llandovery strata in Washington Land. The $r$ element, with short base and a long proclined to erect cusp, possesses a narrow, groove-like, medial, inner furrow and prominent basal notches in the basal margins. 
Panderodus sp. D

Plate 18, figs $1-2$

Remarks. The straight lower margin of the sym. p element is similar to $P$. spasovi Drygant (1969b), but the element differs in the shape of the base, in lacking the double lateral costae and in having basal wrinkles which extend to the basal margin.

Occurrence. Fourteen specimens of this species occur in Pterospathodus celloni Biozone strata of East Peary Land.

\section{Pseudobelodella $\mathrm{n}$. gen.}

Name derivation. From the superficial similarity to $B e-$ lodella Ethington.

Type species. Pseudobelodella silurica $\mathrm{n}$. gen. n. sp.

Diagnosis. Quadrimembrate; sym. p, ap, aq and sq elements. All strongly compressed and bearing upper edge dentides.

Remarks. The presence of an ap and the morphology of the sym.p element distinguish this genus from Belodella Ethington.

Pseudobelodella is apparently restricted to deeper water environments in the upper Pterospathodus celloni and $P$. amorphognathoides Biozones.

Pseudobelodella silurica n. gen. n. sp.

Plate 18, figs 3-9

1978 Belodella n. sp. A; Miller, p. 341, pl. 1, figs 19-23

1987 Belodella n. sp. A; Over \& Chatterton, pl. 6, figs 4, 8-11.

Name derivation. From the apparent restriction of this species to Silurian strata.

Holotype. Specimen MGUH 17-947; pl. 18, fig. 4 a sym. p. element from GGU 216853 within the Lafayette Bugt Formation. Pterospathodus amorphognathoides Biozone, at Kap Schuchert, Washington Land, western North Greenland.

Diagnosis. As for the genus.

Description. sym. p element. Strongly compressed, erect element, with a slightly inwardly bowed cusp. The element has a broad base and tapers gradually towards the apex. Its upper margin bears numerous short, almost completely fused, apically inclined, peg-like denticles. Basally, the upper margin is adenticulate and forms a short heel, of which the extreme basal corner is slightly extended. The lower margin is straight to gradually posteriorly curved, curvature increasing apically, particularly in forms with an inwardly twisted apex. The basal margin is straight beneath the lower lateral faces and inclined beneath the heel, a prominent basal notch is located centrally on both inner and outer-basal margins. The entire surface is deeply excavated. The faces are laterally identical, a broad flat lower face being separated from an apically tapering, upper face by a narrow groove-like furrow and step-like costa, both extending to the tip of the cusp from the basal notch. At the base of the cusp both costa and groove migrate towards the posterior edge of the cusp, continuing to the apex just beneath the denticle row. The cavity is tall and apically triangular, terminating close to the lower margin at approximately two-thirds the height of the element. White matter is concentrated into the apex, above the basal cavity tip and occasionally is apparent within the denticles.

ap element. Less strongly compressed than the slightly inwardly bowed sym. p. element. Distinguished from the aq in having a straight lower margin, more erect. The upper edge bears apically inclined, almost completely fused denticles. The basal margin is commonly straight, developing a shallow furrow on the outer face. A weakly developed step-like costa runs parallel to the lower margin from the base to the apex. The inner face bears a prominent costa close to and parallel with the lower margin, extending from the top of the basal wrinkles to the apex. Basal cavity outline and white matter distribution are as described for the sym. p. element.

aq element. Identical to the ap element in all features except greater recurvature.

sq element. Compressed, strongly recurved, biconvex element. The base is broad, the cusp steeply proclined to erect. The upper margin of the base is straight and bears four to six tall, peg-like, partially fused denticles. Basally the edge is adenticulate and forms a heel of similar morphology to that of the other elements in the apparatus. The upper edge of the cusp is sharp and more or less straight, the lower margin develops a low keel, extending from just apical of the lower-basal corner to the apex of the element. The lower face is subdivided as in the sym. p element by a step-like costa, the costa migrates upwards and just below the base of the cusp is extremely close to the upper margin. The outer face is smooth and broadly convex. A zone of fine basal wrinkles passes around the base, these are more conspicuous on the outer face. The entire basal surface is excavated and, though shorter, the basal cavity is as 
described for the other elements. White matter is restricted to the cusp and has not been seen in the denticles.

Occurrence. P.? silurica is restricted to the $P$. celloni and P. amorphognatoides Biozones of Peary Land, Kronprins Christian Land, Hall Land and Washington Land.

Remarks. Miller (1978, p. 341) described Belodella n. sp. A from the Hidden Valley Dolomite of California, noting that these specimens (aq elements) were distinct from previously reported species of Silurian or Devonian age. Over \& Chatterton (1987, pl. 6, figs 4, 8-11) reconstructed Bellodella $\mathrm{n}$. sp. A, Miller as four 'forms', a (aq), b (?aq), c (sym. p.) and d (ap). An additional sq element occurs in the Greenland collection.

\section{Genus Pseudooneotodus Drygant, 1974c}

Type species. Oneotodus (?) beckmanni Bischoff \& Sannemann 1958, p. 98.

Diagnosis. Refer to Barrick (1977, p. 57).

Remarks. Barrick (1977, p. 57) emended the generic diagnosis and reconstructed the apparatus of $P$. bicormis and $P$. tricornis, each comprising a slender conical element, a squat conical element and a diagnostic bi- or tri-denticulate squat conical element. Bischoff (1986) emended the diagnosis of Pseudooneotodus based upon his conclusion that the apparatus was unimembrate. The Greenland collection confirms a trimembrate apparatus. Unidenticulate elements appear to be vicarious. Homology of elements in the Pseudooneotodus apparatus with those in other coniform apparatus plans is problematical. Pseudooneotodus elements lack lateral costae for orientation and no obvious morphological transition occurs between the elements. The slender conical element is erect and may homologise with the $p$ elements of other genera; the squat conical elements are the most abundant and show the greatest morphological variation, characters commonly found in the q elements in other coniform genera.

\section{Pseudooneotodus cf. P. beckmanni (Bischoff \&} Sannemann, 1958)

cf. 1958 Oneotodus? beckmanni p. 58, pl. 15, figs 22-25. cf. 1977a Pseudooneotodus beckmanni; Cooper, p. 1068, pl. 2, figs 14,17 .

Description. Squat, unidenticulate, broad based, conical elements. Specimens from Greenland are indistinguishable from the squat, conical, unidenticulate element of Pseudooneotodus bicornis Drygant (pl. 20, figs 11, 12).

Remarks. The apparatus of $O$. beckmanni has previously not been fully described. Jentzsch (1962, p. 969 , pl. 1, fig. 8) reported the slender conical element Oneotodus variabilis Lindström in association with a uni-

\section{Plate 18}

Figs 1, 2. Panderodus sp. D.

1 , outer lateral view of sym. p elemen, $\times 60$ : MGUH 17.945 .

2 , microstriations on outer lateral face of sym. p element, $x$ 240; MGUH 17.945.

Figs 3-9. Pseudobelodella silurica n. gen. n. sp.

All specimens from GGU 216853 unless otherwise stated, $\times$ 60.

3, lateral view of sym. p element; MGUH 17.946.

4. lateral view of sym. p element; MGUH 17.947 (holotype).

5 , inner lateral view of slender aq element; MGUH 17.948.

6, outer lateral view of slender aq element; MGUH 17.949.

7. inner lateral view of broad aq element; MGUH 17.950.

8 , inner lateral view of sq element; MGUH 17.951.

9, outer lateral view of sq element; MGUH 17.952 from GGU 229037.

Figs 10-15. Pseudooneotodus bicornis Drygant. All specimens from GGU 228978 unless otherwise stated.

10 , lateral view of slender conical element, $\times 60$; MGUH 17.953 from GGU 228975.

11 , upper view of squat unidenticulate element, $\times 40$; MGUH 17.954 .
12 , lateral view of squat unidenticulate element, $\times 40$; MGUH 17.955 .

13 , lateral view of squat bidenticulate element, $\times 40$; MGUH 17.956.

14 , upper view of squat bidenticulate element, $\times 40$; MGUH 17.957.

15 , upper view of squat bidenticulate element, $\times 40 ;$ MGUH 17.958 .

Figs 16-18. Pseudooneotodus tricornis Drygant.

All specimens $\times 60$.

16, lateral view of slender conical element; MGUH 17.959 from GGU 228978.

17, upper view of squat unidenticulate element; MGUH 17.960 from GGU 228975.

18, upper view of tridenticulate element; MGUH 17.961 from GGU 228975 .

Fig. 19. Pseudooneotodus n. sp.

19 , lateral view of slender conical element, $\times 60$; MGUH 17.962 from GGU 216852. 


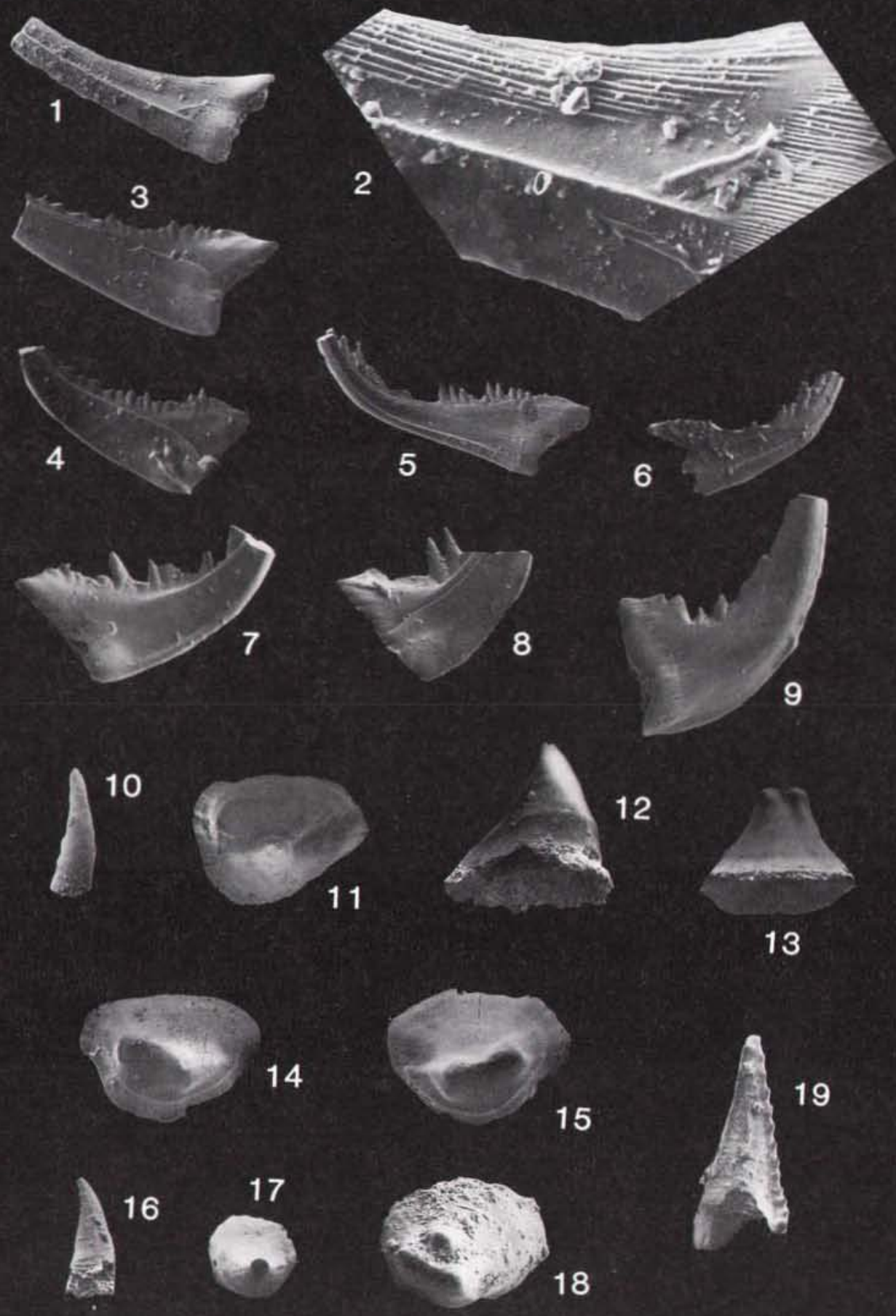


denticulate squat conical element from the Lower Devonian of Thuringa. Cooper (1977a), Nowlan \& Barnes (1981, p. 23) and the Greenland collections suggest that late Ordovician to mid Llandovery Pseudooneotodus had a unimembrate apparatus.

Occurrence. Found infrequently in pre-Pterospathodus celloni Biozone samples from throughout North Greenland. Sample GGU 216835 (fig. 21) contains abundant elements.

\section{Pseudooneotodus bicornis Drygant, 1974c \\ Plate 18, figs 10-15}

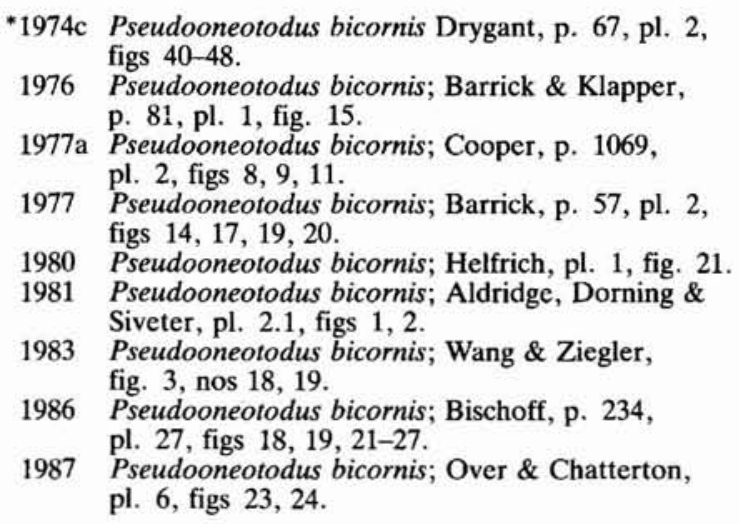

Holotype. Pseudooneotodus bicornis Drygant, 1974c, p. 67 , pl. 2, figs $40-48$.

Diagnosis. Refer to Barrick (1977, p. 58).

Description. The Greenland specimens conform to the descriptions given by Barrick (1977, p. 58). In the moderately large collections from Greenland, both sinistral and dextral bidenticulate elements are present (plate 18 , figs 14,15 ).

Remarks. P. bicornis differs from P. tricornis and P. cf. $P$. beckmanni in having a bidenticulate squat conical element within its apparatus. The ranges of $P$. tricornis and $P$. bicornis overlap in the Børglum Elv and Kap Schuchert sections. Mabillard \& Aldridge (1985) recorded P. bicornis in small numbers in nearshore to offshore environments, but not in deep offshore environments. GGU 228977 (fig. 6) from within graptolitic shale contains the most abundant specimens of $P$. $b i$ cornis in Greenland, though the size distribution of specimens and sample lithology suggest these specimens have undergone some sorting. Phylogenetically, P. bicornis appears to be descended from $P$. cf. P. beckmanni, though its relationship with $P$. tricornis is un- certain. Barrick (1977, p. 58) considered P. bicornis to be derived from $P$. tricornis, stratigraphical occurrences in Børglum Elv are consistent with this suggestion.

Occurrence. Found in seven samples of Pterospathodus celloni Biozone age in Washington Land and Peary Land.

\section{Pseudooneotodus tricornis Drygant, 1974c \\ Plate 18, figs 16-18}

1966 Oneotodus sp. Spasov \& Filipović, p. 43, pl. 2, fig. 6.

*1974c Pseudooneotodus tricornis Drygant, p. 67, pl. 2, figs $49,50$.

1977a Pseudooneotodus tricornis; Cooper, p. 1069, pl. 2, figs 15,16 .

1977 Pseudooneotodus tricornis; Barrick, p. 58, pl. 2, fig. 18.

1983 Pseudooneotodus tricornis; Wang \& Ziegler, fig. 3 , no. 9 .

1986 Pseudooneotodus tricornis; Bischoff, p. 238, figs 20, 28-37.

1987 Pseudooneotodus tricornis; Over \& Chatterton, pl. 6 , figs 21,22 .

Holotype. Pseudooneotodus tricornis Drygant, 1974c, p. 67.

Diagnosis. Refer to Barrick (1977, p. 58).

Description. Slender conical element. This element is identical to that of $P$. bicornis.

Squat conical element. Conical element with a circular basal outline, bearing a single apex which may be slightly curved. The entire element is excavated, and commonly has extremely thin walls.

Squat conical element, tridenticulate. Refer to the description of this element in Barrick (1977, p. 58).

Remarks. Elements of $P$. tricornis are commonly much more fragile and have more circular basal outlines than those of the other species of Pseudooneotodus.

Occurrence. Found rarely in Peary Land, Kronprins Christian Land and Washington Land in strata of Pterospathodus celloni - P. amorphognathoides Biozone age.

Pseudooneotodus n. sp.

Plate 18, fig. 19

Description. Tall slender cone, completely excavated; height approximately twice the basal diameter. Slightly curved apically, compressed slightly in the plane of cur- 
vature. A single serrate longitudinal costa bearing small nodose denticles distinguishes this species from others of Pseudooneotodus.

Remarks. A single specimen of late Silurian age described by Clark \& Ethington (1966, p. 677, pl. 82, fig. 2 ) as Coelocerodontus sp, differs in having keeled anterior and posterior margins.

\section{Genus Pterospathodus Walliser, 1964}

1964 Pterospathodus, p. 66.

1972 Llandoverygnathus Walliser, p. 76.

Type species. Pterospathodus amorphognathoides Walliser, 1964, p. 67.

Diagnosis. Refer to Barrick \& Klapper (1976, p. 82).

\section{Pterospathodus amorphognathoides Walliser, 1964}

Plate 19, figs $1-5$

1962 n. gen. A n. sp. a Walliser, p. 283, fig. 1, no. 12

1962 fig. 1 , no. 11 Walliser, p. 282

v*1964 Pterospathodus amorphognathoides Walliser, p. 67 , pl. 6, fig. 7; pl. 15, figs 9-15; Text fig. 1f.

v1964 Ozarkodina gaertneri Walliser, p. 57 , pl. 6 fig. 6 ; pl. 27, figs 12-19; Text fig. 1g.

v1964 Neoprioniodus triangularis triangularis Walliser, p. 52 , pl. 6 , fig. 13 ; pl. 28 , figs $25-30$; Text figs $6 \mathrm{~d}-\mathrm{f}$.

v1964 Neoprioniodus costatus costatus Walliser, p. 48, pl. 6 , fig. 14 ; pl. 28 , figs $36-41$; Text figs $61-n$.

1966 Pterospathodus amorphognathoides; Spasov, pl. 1 fig. 1 .

1966 Neoprioniodus costatus costatus; Spasov, pl. 1, fig. 5 .

1966 Pterospathodus amorphognathoides; Spasov \& Filipović, p. 48, pl. 1, figs 4-5.

?1966 Ozarkodina gaertneri; Spasov \& Filipović, p. 44, pl. 1, figs $1,2$.

?1966 Neoprioniodus costatus costatus; Spasov \& Filipović p. 42, pl. 1, figs 10,11 .

1967 Pterospathodus amorphognathoides; Flajs, pl. 13 , fig. 10 .

1967 Ozarkodina gaertneri; Flajs, pl. 3, fig. 9.

1967 Neoprioniodus triangularis triangularis; Flajs, pl. 3, fig. 12 .

1967 Neoprioniodus costatus costatus; Flajs, pl. 3, fig. 11.

1968 Pterospathodus amorphognathoides; Igo \& Koike, p. 16 , pl. 2, figs $12-13$.

p1968 Ozarkodina gaertneri; Igo \& Koike, p. 14, pl. 1, figs $5,6,9$

v1969 Pterospathodus amorphognathoides; Nicoll \& Rexroad, p. 56, pl. 3, figs 1-7.

v1969 Ozarkodina gaertneri; Nicoll \& Rexroad, p. 49, pl. 2, figs 12-14.

v1969 Ozarkodina neogaertneri Nicoll \& Rexroad, p. 50 , pl. 2, figs 15,16 .

1969 Pterospathodus amorphognathoides; Schönlaub, pl. 1 , fig. 8 .
1969 Ozarkodina gaertneri; Schönlaub, pl. 1, fig. 15.

1969a Pterospathodus amorphognathoides; Drygant, p. 49 , pl. 1 , fig. 6 .

1970 Pterospathodus amorphognathoides; Manara \& Vai, p. 494, pl. 62, fig. 15; pl. 63, fig. 4.

1970 Ozarkodina gaertneri; Manara \& Vai, p. 487, pl. 62 , fig. 17.

1971 Pterospathodus amorphognathoides; Rexroad \& Nicoll, pl. 2, figs 20,21 .

1971 Ozarkodina gaertneri; Rexroad \& Nicoll, pl. 2, fig. 22

1971 Ozarkodina neogaertneri; Rexroad \& Nicoll, pl. 2, fig. 23 .

1971 Pterospathodus amorphognathoides; Schönlaub, p. 45 , pl. 2 , figs $6-12$.

1972 Pterospathodus amorphognathoides; Rexroad \& Nicoll, pl. 1, figs 4-7.

1972 Ozarkodina gaertneri; Rexroad \& Nicoll, pl. 1, figs 1-3.

1972 Ozarkodina neogaertneri; Rexroad \& Nicoll, pl. 2 , fig. 34 .

1972 Neoprioniodus triangularis; Rexroad \& Nicoll, p. 67 , pl. 2, figs $12-13$.

1972 Neoprioniodus costatus; Rexroad \& Nicoll, pl. 2, figs 8-11.

vp1972 Pterospathodus amorphognathoides; Aldridge, p. 208, pl. 3, figs $17,19$.

vp1972 Ozarkodina gaertneri; Aldridge, p. 200, pl. 5, fig. 5 .

v1972 Distomodus triangularis triangularis; Aldridge, p. 174 , pl. 6 , fig. 12 .

v1972 Neoprioniodus costatus costatus; Aldridge, p. 193, pl. 5, fig. 22.

1972 Pterospathodus amorphognathoides; Walliser, p. 76.

v1974 Pterospathodus amorphognathoides; Aldridge, figs $1 \mathrm{E}-\mathrm{F}$

1975 Pterospathodus amorphognathoides; Klapper \& Murphy, p. 27, pl. 2, fig. 1.

1975 Pterospathodus amorphognathoides; Saladzius, pl. 2 , fig. 7.

v1975 Pterospathodus amorphognathoides; Aldridge, pl. 1, figs 22, 23.

1976 Pterospathodus amorphognathoides; Barrick \& Klapper, p. 82, pl. 1, figs 4, 9-11, 16.

?1976 Pterospathodus amorphognathoides; Kuwano, pl. 2, fig. 2.

1976 Pterospathodus amorphognathoides; Miller, fig. 8, no. 20

1976 Ozarkodina gaertneri; Miller, fig. 8, no. 20.

1977 Pterospathodus amorphognathoides; Liebe \& Rexroad, pl. 1, fig. 9.

1977 Ozarkodina gaertneri; Liebe \& Rexroad, pl. 1, fig. 10 .

1977 Distomodus triangularis; Liebe \& Rexroad, pl. 2 fig. 29.

1977 Neoprioniodus costatus; Liebe \& Rexroad, pl. 2, figs 30,31 .

1977a Pterospathodus amorphognathoides; Cooper, p. 1065 , pl. 2 , figs 3,6 .

1978 Apparatus 'C'; Miller, pl. 4, figs 8-11.

1978 Distomodus triangularis triangularis; Miller, pl.3, fig. 9.

1980 Pterospathodus amorphognathoides; Helfrich, pl. 2, fig. 17-19.

1980 Pterospathodus amorphognathoides; Cooper, p. 219 , fig. 10.

1981 Pterospathodus amorphognathoides; Uyeno \& Barnes, pl. 1, fig. 24.

1981 Pterospathodus amorphognathoides; Nowlan, pl. 7 , fig. 6 . 
1982 Pterospathodus amorphognathoides; Aldridge \& Mohamed, pl. 2, figs 13-16.

1983 Pterospathodus amorphognathoides; Uyeno \& Barnes, pl. 24, pl. 8, fig. 24.

1983 Pterognathodus amorphognathoides; Nowlan, fig. $4 \mathrm{~K}$.

v1983 Pterospathodus amorphognathoides; Mabillard \& Aldridge, pl. 2, figs 25-27.

v1985 Pterospathodus amorphognathoides; Aldridge, p. 86 , pl. 3.3 , figs $7-10$.

1985 Pterospathodus amorphognathoides; Bischoff, p. 186 , pl, 30, figs $19-22$; pl. 31 , figs $15-39$.

1987 Pterospathodus amorphognathoides; Over \& Chatterton, pl. 4 , figs $1-3$.

Holotype. Pterospathodus amorphognathoides Walliser, 1964 , p. 67. Pa element, specimen Wa 745/16 from sample 11D, Cellon Mountain, Carnic Alps, Austria.

Diagnosis. Refer to Barrick \& Klapper (1976, p. 82).

Description. Pa element. The Greenland specimens conform to the description of Pterospathodus amorphognathoides Walliser in Aldridge (1972, p. 208). They differ only in possessing a sigmoidally curved posterior process.

$\mathrm{Pb}$ element. Greenland specimens are indistinguishable from those described as Ozarkodina gaertneri Walliser, by Aldridge (1972, p. 200).

$M$ element. Greenland specimens conform to the description of Distomodus triangularis triangularis (Walliser) in Aldridge (1972, p. 174).

Sc element. Greenland specimens conform to the de- scription of Neoprioniodus costatus costatus Walliser, in Aldridge (1972, p. 193).

Remarks. P. amorphognathoides elements are uncommon in the Greenland collection, occurring without other Pterospathodus species only in GGU 242833 (fig. 16). In other samples they occur with $P$. pennatus rhodesi Savage. Only the $\mathrm{Pa}, \mathrm{Pb}, \mathrm{M}$ and $\mathrm{Sc}$ elements of $P$. amorphognathoides are present in GGU 242833, the $\mathrm{Pb}, \mathrm{M}$ and $\mathrm{Sc}$ elements are identical to their counterparts in P. pennatus rhodesi.

Specimens figured by Spasov \& Filipović (1966) are cited questionably as they occur in a sample with both $P$. amorphognathoides and $P$. pennatus rhodesi $\mathrm{Pa}$ elements.

$\mathrm{Pb}$ elements referred by Link \& Druce $(1972$, p. 64 , pl. 6, figs 10,13) to Ozarkodina gaertneri, from Ludlow strata in the Yass Basin, New South Wales are not closely similar to the $\mathrm{Pb}$ element in either $P$. amorphognathoides or $P$. pennatus rhodesi.

Walliser (1964, p. 16) considered P. pennatus pennatus to be the ancestor of $P$. amorphognathoides. On morphological and stratigraphical evidence $P$. pennatus rhodesi is an intermediate in this lineage. Complications arise with this hypothesis when considering $P$. pennatus angulatus Walliser (1964, pl. 14, fig. 21) which developed a bifurcating outer process in the lower $P$. celloni Biozone and ranged into the Wenlock (Aldridge, 1975, pl. 3, fig. 18). P. pennatus angulatus was thus coeval with $P$. amorphognathoides during the upper part of its range, but the nature of any relationship is uncertain.

\section{Plate 19}

Figs 1-5. Pterospathodus amorphognathoides Walliser. All specimens from GGU 242833, unless otherwise stated.

1, upper view of Pa element, $\times 20$; MGUH 17.842 from GGU 275048.

2 , inner-lateral view of $M$ element, $\times 60$; MGUH 17.843 .

3 , inner-lateral view of Pb element, $\times 60$; MGUH 17.844 .

4 , inner-lateral view of ?juvenile Sc element, $\times 60$; MGUH 17.845 .

5 , microstriations on the cusp of $\mathrm{Pb}$ element, $\times 200 ;$ MGUH 17.844 .

Figs 6-14. Pterospathodus celloni (Walliser)

All specimens $\times 60$ unless otherwise stated.

6, inner-lateral view of Pa element; MGUH 17.846 from GGU 228975.

7, inner-lateral view of Pa element, MGUH 17.847 from GGU 184125 .

8, inner-lateral view of Pa element; MGUH 17.848 from GGU 229037.

9. inner-lateral view of Pb element; MGUH 17.849 from GGU 228975 .
10 , microstriations on the inner-lateral face of the cusp of $\mathrm{M}$ element, $\times 200$; MGUH 17.850 from GGU 184125 .

11, inner-lateral view of M element; MGUH 17.851 from GGU 184125 .

12, posterior view of ?Sa element; MGUH 17.852 from GGU 229037.

13, posterior view of ?Sb element; MGUH 17.853 from GGU 229037.

14, inner-lateral view of Sc element; MGUH 17.854 from GGU 229037

Figs 15-17. Pterospathodus pennatus pennatus (Walliser). All specimens $\times 60$.

15, upper view of $\mathrm{Pa}$ element; MGUH 17.855 from GGU 228970.

16, upper view of Pa element; MGUH 17.856 from GGU 216821 .

17, upper view of $\mathrm{Pa}$ element; MGUH 17.857 from GGU 216821 . 

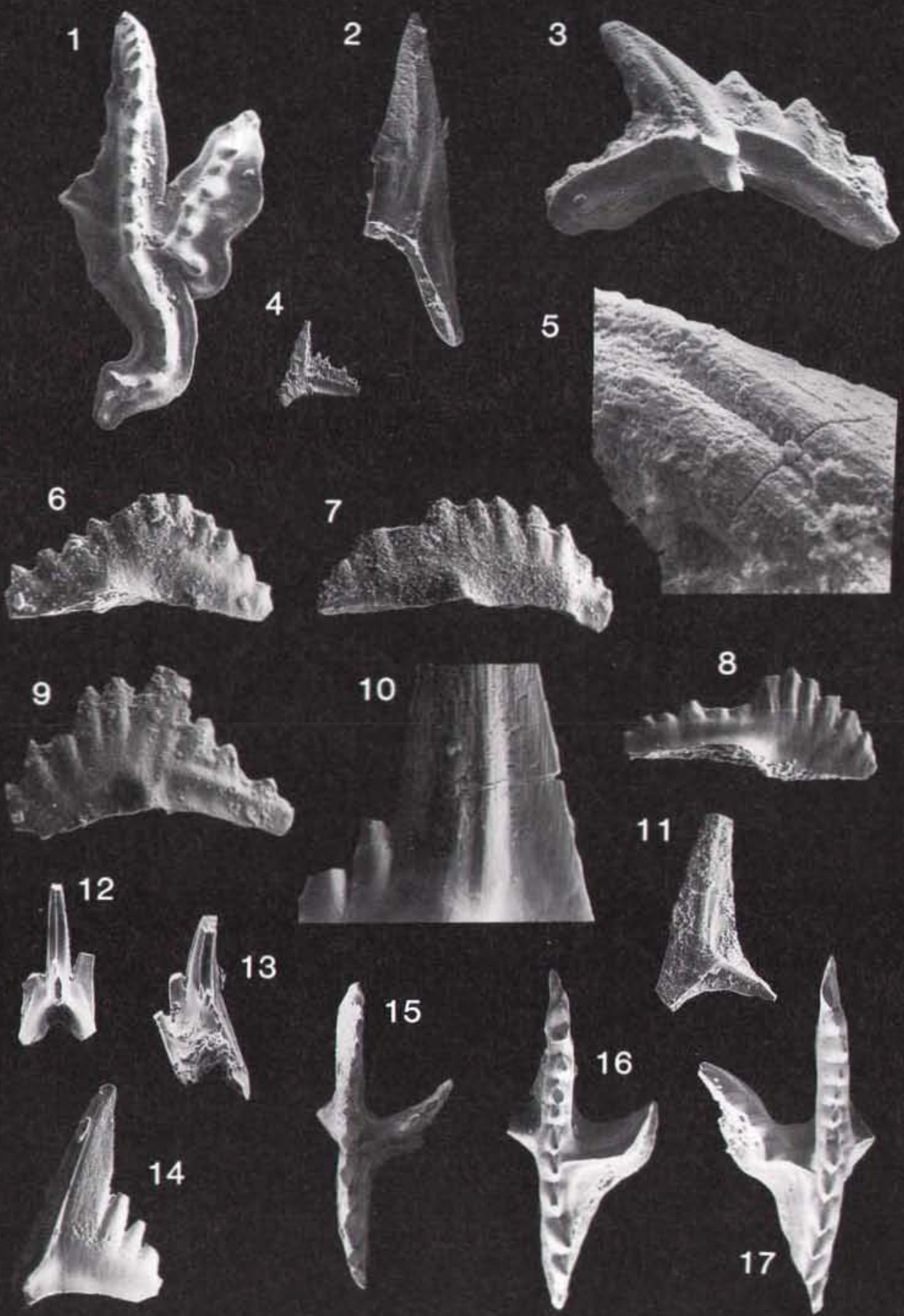
Pterospathodus celloni (Walliser, 1964)

Plate 19 , figs 6-14

1962 Spathognathodus n. sp. b Walliser, p. 282, fig. 1, no. 9.

1962 Ozarkodina n. sp. a Walliser, p. 282, fig. 1, no. 7.

v1964 Spathognathodus celloni Walliser, pp. 73-74, pl. 4, fig. 13; pl. 14, figs 3-16; Text figs $1 \mathrm{~b}$, 7b-f

v1964 Ozarkodina adiutricis Walliser, p. 54, pl. 4, fig. 14; pl. 27, figs 1-10; Text figs $1 \mathrm{a}, 7 \mathrm{~h}-\mathrm{m}$.

v1964 Neoprioniodus triangularis tenuirameus Walliser, p. 53 , pl. 4 , fig. 15 ; pl. 28 , figs 21-24; Text figs $6 \mathrm{a}-\mathrm{c}$.

?v1964 Roundya brevialata Walliser, p. 69, pl. 4, fig. 16; pl. 31 , fig. 8-10.

v1964 Neoprioniodus costatus paucidentatus Walliser, p. 48 , pl. 4 , fig. 23 ; pl. 28 , figs $31-35$; Text figs $6 \mathrm{i}-\mathrm{k}$.

1968 Spathognathodus celloni; Igo \& Koike, pl. 18, pl. 2, figs 1-4.

1968 Ozarkodina gaertneri; Igo \& Koike, p. 14, pl. 1, figs $5-9$.

1968 Neoprioniodus triangularis tenuirameus; Igo \& Koike, p. 13, pl. 3, figs 18-19.

p1968 Multioistodus sp. Igo \& Koike, p. 12, pl. 2, figs $16,17,19$; non fig. 18 .

p1968 Neoprioniodus costatus paucidentatus; Igo \& Koike, p. 12, pl. 3, fig. 16; non fig. 17

v1969 Neospathognathus celloni; Nicoll \& Rexroad, p. 45 , pl. 2, figs $1-4$.

v1969 Ozarkodina adiutricis; Nicoll \& Rexroad, p. 48, pl. 2 , fig. 8 .

1970 Spathognathodus celloni; Moskalenko, p. 18, pl. 2, fig. 3, 4 .

1970 Ozarkodina adiutricis; Moskalenko, p. 14, pl. 2, fig. 1 .

1971 Spathognathodus celloni; Schönlaub, p. 44, pl. 2, fig. 1-5.

1972 Neospathognatodus celloni; Rexroad \& Nicoll, pl. 1 , figs $2-4$.

1972 Ozarkodina adiutricis; Rexroad \& Nicoll, pl. 1, fig. 5 .

1972 Spathognathodus celloni; Rexroad \& Nicoll, p. 68 , pl. 1 , figs $17-19$.

1972 Ozarkodina adiutricis; Rexroad \& Nicoll, pl. 1, figs 15,16 .

v1972 Neospathognathodus celloni; Aldridge, p. 197, pl. 3, figs 9-12.

v1972 Ozarkodina adiutricis; Aldridge, p. 198, pl. 5, figs 2,3 .

?vp1972 Exochognathus brevialatus; Aldridge, p. 177, pl. 7, fig. 8; non fig. 9 .

v1972 Neoprioniodus costatus paucidentatus; Aldridge, p. 193 , pl. 5 , figs $20-21$.

1975 Pterospathodus celloni; Klapper \& Murphy, p. 27, pl. 2, figs 2,3 .

1975b Llandoverygnathus celloni; Schönlaub, p. 53, pl. 1 , figs 18,19 .

v1975 Llandoverygnathus celloni; Aldridge, pl. 1, figs 20,21 .

1976 Pterospathodus celloni; Barrick \& Klapper, p. 82, pl. 1, figs 3,5 .

1977 Spathognathodus celloni; Liebe \& Rexroad, pl. 1, fig. 12 .

1977 Ozarkodina adiutricis; Liebe \& Rexroad, pl. I, fig. 10.

1978 Apparatus 'B'; Miller, pl. 4, figs 1-4

1978 Exochognathus brevialatus; Miller, pl. 3, figs 7, 9.

1978 Neoprioniodus costatus paucidentatus; Miller, pl. 2, fig. 12 .
1978 Neospathognathodus celloni; Pickett, pl. 1, fig. 26.

1978 Ozarkodina adiutricis; Pickett, pl. 1, fig. 17.

v1979 Llandoverygnathus celloni; Aldridge, pl. 1, figs 9, 10.

?v1979 Llandoverygnathus sp. Aldridge, pl. 1, figs $12-15$.

1980 Pterospathodus celloni; Helfrich, pl. 2, fig. 30.

1981 Pterospathodus celloni; Uyeno \& Barnes, pl. 1, figs $20,21$.

1982 Pterospathodus celloni; Aldridge \& Mohamed, pl. 2 , fig. 7 .

1983 Pterospathodus celloni; Uyeno \& Barnes, p. 24, pl. 5, figs $17,18,20-24$.

v1985 Pterospathodus celloni; Aldridge, p. 80, pl. 3.1, figs $25,26$.

1986 Pterospathodus celloni; Bischoff, pl. 28, figs $34-39$; pl. 29 , figs $1-8$.

Holotype. Spathognathodus celloni Walliser (1964), pl. 14, fig. 5. Specimen number Wa740/11 from sample 10J in the Cellon Mountains, Carnic Alps, Austria.

Diagnosis. Refer to Barrick \& Klapper (1976, p. 83).

Description. Pa element. Refer to the description of Neospathognathodus celloni Walliser in Aldridge (1972, p. 197). Greenland specimens of the Pa element fall into the range of morphologies of Spathognathodus celloni illustrated by Walliser (1964).

$\mathrm{Pb}$ element. Refer to the description of Ozarkodina adiutricis Walliser in Aldridge (1972, p. 198).

$M$ element. This element has been previously illustrated as Neoprioniodus triangularis tenuirameus and described fully by Aldridge (1972, p. 173).

?Sa element. Small, modified alate element with denticulate antero-lateral processes and a short posterior process. The cusp is tall and posteriorly curved; its anterior face is broadly convex, its antero-lateral edges bear tall costae, and its posterior edge is sharp. The lateral processes are deep and form an angle of approximately $75^{\circ}$ between lower edges; each process commonly bears a single, rarely two, tall, compressed denticles. The denticles are discrete when two are present. The posterior process is short and slightly inclined downwards, it bears up to three squat, partially fused, compressed denticles. The entire lower surface of the element is deeply excavated, the basal cavity extending as a tapering groove to the tips of the processes. Fine microstriations are situated on the postero-lateral faces of the cusp, the posterior faces of the antero-lateral processes, on the upper portion of the posterior process and lower half of the posterior denticles.

?Sb element. Tertiopedate element, identical to the Sa except for the absence of the denticles on the innerlateral process. The inner antero-lateral costa extends down the cusp to the tip of the inner-lateral process. 
Sc element. Refer to the description on Neoprioniodus costatus paucidentatus Walliser by Aldridge (1972, p. 193). The angle of divergence of the outer lateral process of the Greenland specimens shows slight variation between $120^{\circ}$ and $140^{\circ}$ from the posterior process.

Remarks. Jeppsson (1979a, p. 236) and Mabillard \& Aldridge (1983) suggested the inclusion of Exochognathus brevialatus (Walliser) as a possible Sa-Sb element. Similar specimens occur rarely in Greenland along with $P$. celloni and are questionably included in its apparatus as the $\mathrm{Sa}$ and $\mathrm{Sb}$ elements. The ancestry of $P$. celloni is currently obscure. Bischoff (1986, p. 195) emended the diagnosis of $P$. celloni based upon his reconstruction of $P$. cadiaensis. R. J. Aldridge (Nottingham, personal communication) is currently reviewing Pterospathodus and the old diagnosis for $P$. celloni is retained herein.

Occurrence. Found throughout North Greenland, elsewhere this species is the index species of the $P$. celloni Biozone, and is restricted to lower Telychian strata in Europe and North America.

\section{Pterospathodus pennatus Walliser, 1964}

Emended diagnosis. Five members of the apparatus are known: $\mathrm{Pa}, \mathrm{Pb}, \mathrm{M}, \mathrm{Sa}$ and $\mathrm{Sc}$. Species distinguished by the blade-like stelliscaphate or stelliplanate Pa element which develops a straight to markedly flexed, denticulate, anteriorly directed, outer-lateral process and a short offset adenticulate inner lobe.

Remarks. Walliser (1964) proposed three subspecies based on differences in the morphology of the outer process of the $\mathrm{Pa}$ element. These characters appear to vary within a single population (Walliser, 1964; Nicoll \& Rexroad, 1969). Jeppsson (1979b) concluded that a full taxonomic revision of Pterospathodus was required.

Pterospathodus pennatus pennatus Walliser, 1964 Plate 19, figs 15-17; plate 20, figs $1-5$

v1964 Spathognathodus pennatus pennatus Walliser, p. 79 , pl. 14, figs $23-26$; pl. 15 , fig. 1 , text fig. 1d.

pv1964 Spathognathodus pennatus angulatus Walliser, p. 79 , pl. 14, figs 19,22 ; non fig. 21 .

$v^{*} 1964$ Spathognathodus pennatus pennatus Walliser, p. 79 , pl. 14 , figs $23-26$; pl. 15 , fig. 1 ; text fig. Id.

v1969 Neospathognathodus pennatus; Nicoll \& Rexroad, p. 47 , pl. 2 , fig. 5 .

v1972 Neospathognathodus pennatus; Aldridge, p. 197, pl. 3, figs 13, ?16. v1975 Llandoverygnathus pennatus; Aldridge, $\mathrm{pl} .1$, figs 24,25 .

1975 Pterospathodus pennatus angulatus; Klapper \& Murphy, p. 28, pl. 2, figs 5, 6 .

1978 Pterospathodus pennatus; Miller, pl. 4, figs 12 13.

1978 Neospathognathus pennatus; Pickett, pl. 1, fig. 24 .

v1979 Llandoverygnathus pennatus; Aldridge, pl. 1, fig. 11.

?1981 Pterospathodus pennatus; Nowlan, pl. 7, fig. 1.

?1983 Pterospathodus pennatus; Nowlan, fig. 4S.

Holotype. Spathognathodus pennatus pennatus Walliser 1964 , p. 79 , pl. 14, fig. 26; specimen number Wa 740/22, from sample $10 \mathrm{~J}$, in the $P$. celloni Biozone of Cellon Mountain, Carnic Alps, Austria.

Emended diagnosis. Subspecies of $P$. pennatus with $\mathrm{Pa}$ element that develops a narrow single-branched, straight to slightly flared inner process.

Description. Refer to the description of Neospathognathodus pennatus by Aldridge (1972, p. 197).

$\mathrm{Pb}, \mathrm{M}, \mathrm{Sa}$, and $\mathrm{Sc}$ elements. Samples containing only $P$. pennatus pennatus are not present in Greenland. Samples containing $P$. pennatus pennatus and $P$. pennatus rhodesi, however, allow the separation of the constituent elements. The latter has elements indistinguishable from those of $P$. amorphognathoides. The former has elements virtually indistinguishable from those in $P$. celloni. The $\mathrm{Pb}$ element of the $P$. pennatus pennatus has a slightly shorter anterior process than its counterpart in $P$. celloni, in other respects it is indistinguishable. The $\mathrm{M}$ element may be slightly more inwardly curved.

Sa element. The posterior edge of the cusp is flattened and passes downwards into a short adenticulate posterior process. Each lateral process bears only a short, single denticle or as in the figured example (plate 20 , fig. 3) is adenticulate, the upper edge being broadly rounded.

Sc element. Dolabrate and laterally compressed, the cusp is tall, its inner face flat to shallowly concave, its outer face is broadly concave and towards its base has a short low costa projection, a weak trace of this may pass up the cusp. The outer face of the cusp bears vertical microstriations. The cusp is extended downwards into a short anticusp which is occasionally slightly posteriorly recurved. A slightly inwardly bowed posterior process bears two or three tall, compressed denticles which are fused almost to their tips, these decrease in height gradually towards the posterior; the two proximal denticles are only slightly shorter than the cusp. The basal cavity is narrow and deeply excavated beneath the cusp, extending as a groove to the tip of the anticusp; the cavity terminates before the tip of the posterior process. 
Remarks. The holotypes of $S$. pennatus angulatus Walliser (1964, p. 79, pl. 14, fig. 22) and S. pennatus pennatus Walliser (1964, p. 79, pl. 14, fig. 26) differ only in the degree of basal cavity flare beneath the posterior of the inner process. This feature is seen to intergrade in specimens from Greenland, Gullet 4 (Aldridge, 1972) and Cellon (compare Walliser, 1964, pl. 14, fig. 26 and pl. 15 , fig. 1). Walliser (1964, p. 79 , pl. 14 , fig. 24 ) illustrated a specimen of $S$. pennatus angulatus with a rudimentary denticle posteriorly offset at the flexure of the outer process. This specimen occurs in sample C.10B within the lower Pterospathodus celloni Biozone and cannot therefore be a juvenile of $P$. amorphognathoides. Specimens with a pronounced flexure of the outer process referred to $P$. pennatus angulatus (e.g. Aldridge \& Mohamed, 1982, pl. 2, figs 8-11) should be assigned to a new subspecies.

The holotype of $P$. pennatus procerus Walliser (1964, p. 80 , pl. 15, fig. 5) is also similar to that of $P$. pennatus pennatus. It has, however, a straighter outer process and narrow basal cavity beneath the posterior process, characters seen to be consistent in the paratypes (Walliser, 1964, pl. 15, figs 7, 8). Jeppsson (1979b, p. 235, pl. 71, figs 1-8) reconstructed the apparatus of this subspecies and included ramiform elements with morphology close to that in Carniodus carnulus. The apparatus structures of the other $P$. pennatus subspecies would not be consistent with this interpretation which is based on very low numbers of specimens. The $P$. pennatus pennatus 'plexus' appears to have evolved from $P$. celloni by the modification of the outer process (Walliser, 1964, p. 16, fig. 1).
Occurrence. $P$. pennatus pennatus occurs abundantly in the Pterospathodus celloni Biozone and rarely in $P$. amorphognathoides Biozone samples.

Pterospathodus pennatus rhodesi (Savage, 1985) Plate 20, figs 6-16

1966 Spathognathodus pennatus procerus; Spasov \& Filipović, p. 50, pl. 1, fig. 6.

1985 Pterospathodus n. sp. A; Stouge \& Stouge, p. 109110 , pl. 1, figs $1-6$.

1987 Pterospathodus pennatus rhodesi; Over \& Chatterton, p. 20-21, pl. 4, figs 5,6 .

Holotype. Specimen USNM 371651 p. 714, figs 3A, B from bed 18, Heceta Limestone, Cap Island, southeastern Alaska.

Diagnosis. Refer to Savage (1985, p. 714).

Description. Pa element. Stelliplanate, straight to posteriorly bowed and downturned carina; with two offset lateral processes situated close to the midlength. The carina bears up to twenty fused, nodose denticles, those to the anterior of the lateral processes are tall and more laterally compressed than those to the posterior. The entire element is surrounded by a narrow ledge-like platform. The outer process is long and anteriorly directed, diverging at an angle of $10^{\circ}-45^{\circ}$ from the carina; bears a central row of eight to ten nodose fused denticles which decrease in size distally; it is up to half the length of the carina. An inner process is anteriorly offset and marked by an anteriorly directed expansion

\section{Plate 20}

Figs 1-5. Pterospathodus pennatus pennatus (Walliser). All specimens from GGU $228970, \times 60$.

1, inner-lateral view of $\mathrm{Pa}$ element; MGUH 17.858 .

2 , inner-lateral view of $\mathrm{Pb}$ element; MGUH 17.859.

3 , posterior view of Sa element; MGUH 17.860.

4, inner-lateral view of M element; MGUH 17.861.

5 , inner-lateral view of Sc element; MGUH 17.862.

Figs 6-16. Pterospathodus pennatus rhodesi (Savage). All specimens from GGU 82637 unless otherwise stated.

6, lateral view of $\mathrm{Pa}$ element, $\times 20$; MGUH 17.863 from GGU 275048.

7, inner-lateral view of $\mathrm{Pb}$ element, $\times 40 ;$ MGUH 17.864 from GGU 275048.

8, upper view of Pa element, $\times 20 ;$ MGUH 17.865 (holotype) from GGU 275049.

9. microstriations on the carina of Pa element, $\times 170$; MGUH 17.863 from GGU 275048.

10 , inner-lateral vicw of Sc element, $\times 60$; MGUH 17.867.

11, upper view of Sc element, $\times 60$; MGUH 17.868.
12 , microstriations on the cusp of $\mathrm{M}$ element, $\times 120$; MGUH 17.869.

13, inner-lateral view of $\mathrm{M}$ element, $\times 60$; MGUH 17.869.

14 , posterior view of $\mathrm{M}$ element, $\times 60$; MGUH 17.870 .

15 , posterior view of ?Sa element, $\times 60$; MGUH 17.871.

16 , posterior view of ?Sb element, $\times 60 ;$ MGUH 17.872 .

Figs 17-22. Dentacodina aff. D. dubia (Rhodes).

17 , inner-lateral view of $\mathrm{Pa}$ element, $\times 100$; MGUH 17.873 from GGU 216873.

18, oblique upper view of $\mathrm{Pb}$ element, $\times 60$; MGUH 17.874 from GGU 216853.

19 , inner-lateral view of M element, $\times 60 ;$ MGUH 17.875 from GGU 216873.

20 , posterior view of Sa element, $\times 60$; MGUH 17.876 from GGU 216853.

21 , inner-lateral view of Sb element, $\times 60$; MGUH 17.877 from GGU 216853.

22 , inner-lateral view of Sc element, $\times 60$; MGUH 17.878 from GGU 216873. 


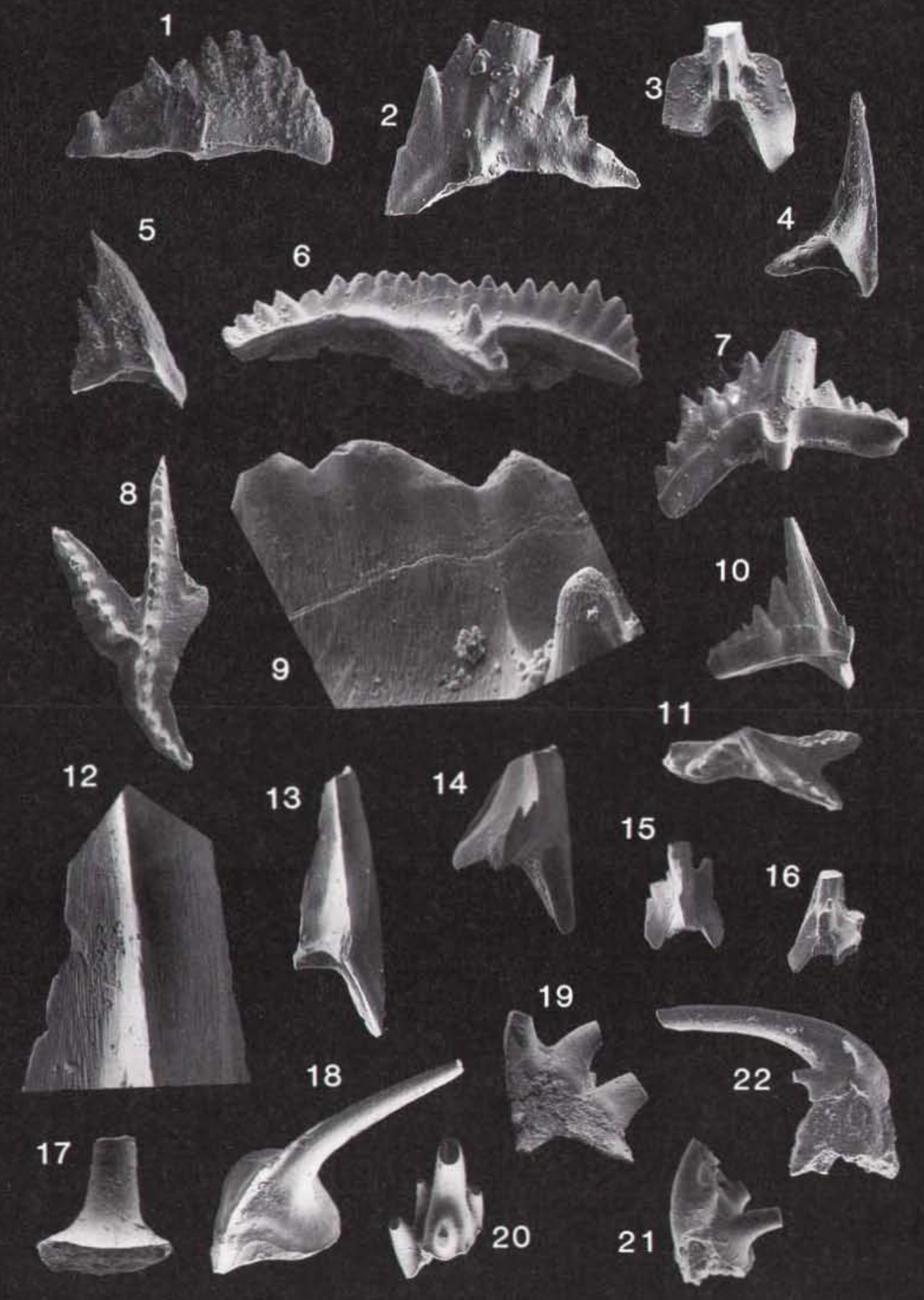


of the platform ledge and a shallow depression which crosses the platform obliquely towards the carina. In lateral view the platform runs at approximately the midheight of the carina, beneath it the element narrows. The basal cavity is shallow, slightly expanded beneath the junction of the processes, extending to the tips of the carina and processes as a narrow tapering groove.

$P b, M$ and $S c$ elements. These elements are inseparable from their counterparts in the apparatus of $P$. amorphognathoides.

?Sa element. Alate with tall, costate cusp, the costae run laterally and posteriorly, downwards into the processes. The lateral processes are compressed, deep and usually bear a single or rarely two denticles. These are shorter than the equivalent denticles in the P. celloni Sa element. The posterior process rarely has short, peglike denticles preserved. The basal cavity is deeply excavated beneath the cusp, extending almost to the tips of the processes.

?Sb element. Lacks the denticulate outer lateral process of the Sa element; but in all other respects is identical.

Remarks. Sample GGU 275048 from Valdemar Glückstadt Land (fig. 4) contains 27 P. amorphognathoides $\mathrm{Pa}$ elements and $323 P$. pennatus rhodesi $\mathrm{Pa}$ elements; the twenty $\mathrm{Pb}$, one ?Sa, one ?Sb and one $\mathrm{Sc}$ element are more likely derived from an apparatus of the latter.

Occurrence. Found in samples of uppermost Pterospathodus celloni - P. amorphognathoides Biozone age from Hall Land, Valdemar Glückstadt Land and Kronprins Christian Land.
Genus Walliserodus Serpagli, 1967

Type Species. Acodus curvatus Branson \& Branson, 1947, by subsequent designation of Cooper (1975, p. 995).

Diagnosis. Refer to Cooper (1975, p. 995).

Remarks. Midheight cross sections for homologous Walliserodus elements are illustrated in fig. 34 .

Walliserodus bicostatus (Branson \& Mehl, 1933a) Plate 21, figs 1-5

*1933a Acodus bicostatus Branson \& Mehl, p. 42, pl. 3, fig. 1.

1971 Acodus biostatus; Rexroad \& Craig, p. 686, pl. 82, fig. 17.

1971 Acodus curvatus; Rexroad \& Craig, p. 686, pl. 82, fig. 17.

Holotype. Acodus biostatus Branson \& Mehl, 1933a, p. 42 , pl. 3 , fig. 1 .

Diagnosis. Apparatus quinquemembrate containing tall, laterally costate sym. $p$ and ap elements and recurved, laterally acostate aq, sq and $r$ elements. This species is distinguished by the sym. p and aq elements which possess double lower-lateral costae.

Description. sym. p element. Laterally compressed, bilaterally symmetrical, broad based cone; base and cusp are subequal in length, the cusp is shallowly proclined. The upper margin is sharp, lacking a prominent keel

\section{Plate 21}

Figs 1-5. Walliserodus bicostatus (Branson \& Mehl). All specimens from GGU 216845, $\times 60$.

1, lateral view of sym. p element; MGUH 17.963.

2, lateral view of ap element; MGUH 17.964.

3 , lateral view of sq element; MGUH 17.965.

4 , inner lateral view of aq element; MGUH 17.966.

5 , inner lateral view of r element; MGUH 17.967.

Figs 6-15. Walliserodus curvatus (Branson \& Branson). All specimens from GGU $216842, \times 60$.

6, inner lateral view of sym. p clement; MGUH 17.968.

7, outer lateral view of sym. p element; MGUH 17.969.

8 , inner lateral view of ap element; MGUH 17.970.

9 , outer lateral view of aq element; MGUH 17.971.

10, inner lateral view of unicostate aq element; MGUH 17.972.

11 , inner lateral view of multicostate aq element; MGUH

12, inner lateral view of costate r element; MGUH 17.974.

13, inner lateral view of costate r element; MGUH 17.975.

14 , inner lateral view of sq element; MGUH 17.976.

15, outer lateral view of sq element; MGUH 17.977.

Figs 16-24. Walliserodus $\mathrm{cf}$. W. sancticlairi Cooper. All specimens from GGU 216852, × 60 .

16, lateral view of sym. p element; MGUH 17.978.

17, lateral view of sym. p element; MGUH 17.979.

18, outer lateral view of ap element; MGUH 17.980.

19, inner lateral view of ap element; MGUH 17.981.

20, inner lateral view of aq element; MGUH 17.982.

21, outer lateral view of aq element; MGUH 17.983.

22, lateral view of sq element; MGUH 17.984.

23 , outer lateral view of $\mathrm{r}$ element; MGUH 17.985 .

24 , inner lateral view of $\mathrm{r}$ element; MGUH 17.986. 

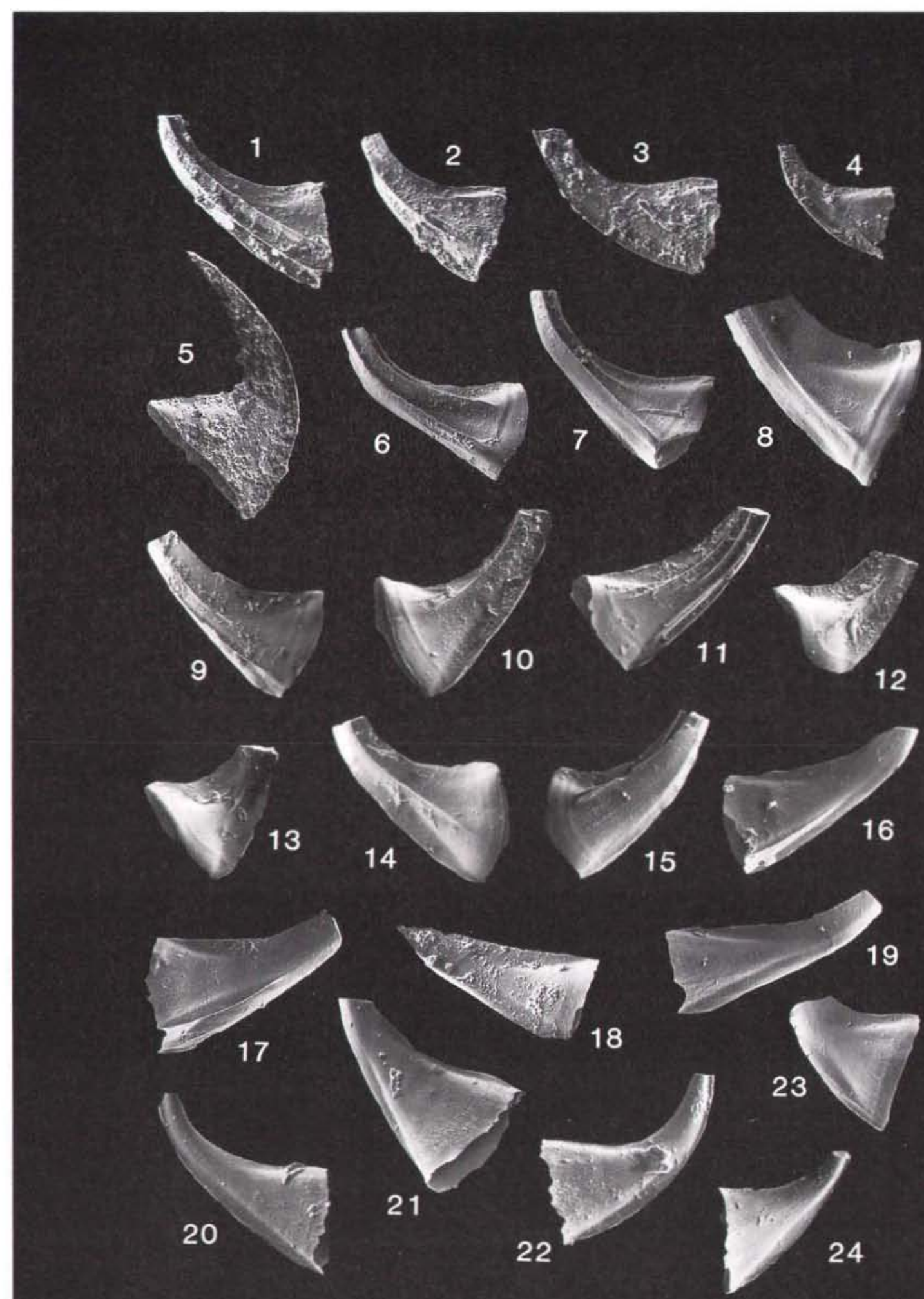
and is more strongly curved than the lower margin. The lower margin is concave laterally and extended on either side by symmetrically disposed double costae; these converge upwards, but remain distinct to the tip of the cusp; a narrow, v-shaped groove separates them. Above the costae the lateral faces are shallowly concave to the upper margin. The basal margin is more or less straight, the basal surface completely excavated. The basal cavity is tall terminating at the base of the cusp close to the lower margin, white matter in all elements in this apparatus is concentrated above the basal cavity, the lateral costae are all filled with white matter.

ap element. Morphologically transitional from the sym. p element, almost identical in lateral outline. The inner face has double, lower costae situated closer to the midline which originate at a point just above the basal margin. When viewed from the inner side the upper margin appears weakly keeled with an additional short costa extending to midheight from the upper basal corner. Outwardly the face posterior of the costae is shallowly concave to the upper margin.

$a q$ element. Slightly more recurved than the $\mathrm{p}$ elements. Upper and lower margins are sharp and bear low keels. The lower keel is directed slightly laterally. The cusp may be twisted in the same direction as this costa. Basally the element is laterally inflated; larger specimens may develop shallow longitudinal lateral faces; the cusp is compressed. This element lacks costae on the lateral faces, which allows its distinction from its counterpart in the $W$. curvatus apparatus.

$s q$ element. Similar curvature to the aq element, laterally compressed and bilaterally symmetrical. Both upper and lower margins are sharp and bear keels, but these are not as prominent as those in other species of Walliserodus. The lateral faces are shallowly convex and lack lateral costae. The basal margin is straight, the entire basal surface excavated.

r element. Strongly recurved, shorter version of the aq element. Its base is shorter than the cusp and triangular cross section, the upper edge is straight, the lower edge gently, apically curved. The strongly, laterally compressed cusp is strongly recurved from its base and twisted inwardly. The lower margin bears a keel which is directed in the same plane as the cusp. The basal surface is entirely excavated.

Remarks. The $\mathrm{q}$ and $\mathrm{r}$ elements of $W$. bicostatus are similar to those of $W$. cf. $W$. sancticlairi, but can be distinguished by their broader bases and cusps and lower keels which are less prominent; the $r$ element is much more strongly recurved.

Rexroad \& Craig (1971) noted the rare occurrence of the sym. p element in the samples of Branson \& Mehl (1933a). The specimens of $P$. multicostatus (Rexroad \& Craig, 1971, pl. 82, figs 20a, 20b) are fragmented, but show affinity to this group of elements. No multicostate aq element is recorded from Greenland, and until this specimen can be studied it is not included in the synonymy.

Occurrence. Found only in GGU 216845 and 242911 (figs 16, 21).

\section{Walliserodus curvatus (Branson \& Branson, 1947)}

Plate 21, figs 6-15

v1947 Acodus unicostatus Branson \& Branson, p. 554, pl. 82, figs $9,10,41,43$.

vp1947 Paltodus acostatus Branson \& Branson, p. 554, pl. 82 , figs 23, 24; non figs 1-5.

v1947 Acodus curvatus Branson \& Branson, p. 554, pl. 81 , fig. 20.

vp1947 Paltodus unicostatus; Branson \& Branson, p. 554 pl. 82, figs 11-16; non figs 6-10, 17-22.

?1964 Acodus cf. mutatus; Serpagali \& Greco, p. 196, pl. 34 , figs $2 \mathrm{a}, \mathrm{b}$.

v1967 Acodus unicostatus; Rexroad, p. 26, pl. 4, figs 13-16.

v1967 Acodus curvatus; Rexroad, p. 25, pl. 4, figs 9-12.

v1967 Paltodus debolti Rexroad, p. 41, pl. 4, figs $22-25$.

v1967 Paltodus dyscritus Rexroad, p. 42, pl. 4, figs $30-34$.

v1967 Paltodus migratus Rexroad, p. 44, pl. 4, figs $17-21$.

v1969 Acodus unicostatus; Nicoll \& Rexroad, p. 23, pl. 7, figs 34-36.

v1969 Acodus curvatus; Nicoll \& Rexroad, p. 23, pl. 7, figs $19,20$.

v1969 Paltodus debolti; Nicoll \& Rexroad, p. 52, pl. 7, fig. 26 .

v1969 Paltodus dyscritus; Nicoll \& Rexroad, p. 52, pl. 7, fig. 26.

v1969 Paltodus migratus; Nicoll \& Rexroad, p. 52, pl. 7, fig. 27.

1970 Acodus unicostatus; Pollock, Rexroad \& Nicoll, p. 749 , pl. 114 , figs $36-37$.

1970 Acodus curvatus; Pollock, Rexroad \& Nicoll, p. 749 , pl. 114 , fig. 35 .

1970 Paltodus debolti; Pollock, Rexroad \& Nicoll, p. 758, pl. 114 , figs 32,33 .

1970 Paltodus dyscritus; Pollock, Rexroad \& Nicoll, p. 758 , pl. 114 , fig. 31

v1972 Acodus unicostatus; Aldridge, p. 162, pl. 9, figs 2,3 .

v1972 Acodus curvatus; Aldridge, p. 162, pl. 9, fig. 1.

v1972 Paltodus debolti; Aldridge, p. 202, pl. 9, fig. 18.

v1972 Paltodus dyscritus; Aldridge, p. 203, pl. 9, fig. 19.

v1972 Paltodus migratus; Aldridge, p. 203, pl. 9, fig. 20.

1972 Acodus unicostatus; Rexroad \& Nicoll, pl. 1, figs $48,49$.

1972 Paltodus dyscritus; Rexroad \& Nicoll, pl. 2, fig. 35 ,

1972 Acodus? curvatus; Miller, p. 558, pl. 1, figs 1, 2.

1972 Paltodus trigonus; Miller, p. 562, pl. 1, figs $18-20$. 
1972 Paltodus debolti; Miller, p. 562, pl. 1, figs 15-17.

$1974 \mathrm{c}$ Paltodus debolti; Drygant, pl. 2, fig. 1.

1974 c Acodus unicostatus; Drygant, pl. 2, fig. 2.

1974c Paltodus dyscritus; Drygant, pl. 1, fig. 34.

1975 Walliserodus curvatus; Cooper, p. 995, pl. 1, figs 10, 11, 16-21.

1975 Paltodus dyscritus; Thompson \& Satterfield, fig. 5D.

1977 Acodus unicostatus; Liebe \& Rexroad, pl. 2, figs $20,21$.

1977 Acodus curvatus; Liebe \& Rexroad, pl. 2, figs 14,15 .

1977 Paltodus dyscritus; Liebe \& Rexroad, pl. 2, fig. 1 .

1977 Paltodus debolti; Liebe \& Rexroad, pl. 2, figs 2, 3.

1977 Paltodus multicostatus; Liebe \& Rexroad, pl. 2, fig. 4 .

?1977 Paltodus fragilis; Liebe \& Rexroad, pl. 2, figs 5, 6.

?1977 Paltodus sp. A Liebe \& Rexroad, pl. 2, fig. 7.

?1977 Paltodus sp. B Liebe \& Rexroad, pl. 2, figs 5, 8, 9.

1978 Walliserodus curvatus; Rexroad, Noland \& Pollock, pl. 12, pl. 1, figs 1-5.

1978 Walliserodus curvatus; Miller, p. 341, pl. 1, figs $10-17$.

1981 Walliserodus curvatus; McCracken \& Barnes, pl. 2, figs 2, 4 .

Holotype. Acodus curvatus Branson \& Branson, 1947, p. 554; from loc. 1923, the lower Silurian Brassfield Formation of Kentucky.
Emended diagnosis. Five elements known with short cusps and long broad bases. The sym. $p$ and ap elements bear single laterally directed keel-like lower costae, the aq, sq and $r$ elements are more markedly recurved and have keeled lower margins. The aq element bears between one and three longitudinal costae on the inner face.

Description. sym. p element. Refer to the description of Paltodus dyscritus Rexroad in Aldridge (1972, p. 203). Basal cavity outline is illustrated in fig. 34; white matter is concentrated above the basal cavity apex, extending basally along the lateral costae in large specimens.

ap element. Refer to the description of Acodus unicostatus Branson \& Branson in Aldridge (1972, p. 162). Maybe morphologically transitional from the sym. p element, intermediates occur only infrequently in large collections.

Unicostate - aq element. Refer to the description of Paltodus debolti sensu Rexroad in Aldridge (1972, p. 202). The more common of the two aq elements differs from the pelements in being more steeply and gradually apically curved and lacks costae on the outer side.

A rare multicostate morphotype occurs in which three additional costae are developed on the inner face. The most prominent of these is situated close to the
Fig. 34. Species of Walliserodus illustrating the distribution of costae, outline of basal cavity and cross-section at midheight. Camera lucida drawings. MGUH numbers, $p$ elements (from top to bottom) $17.968,17.970$, $17.963,17.964,17.978,17.981 ; q$ elements (top to bottom) 17.973, $17.972,17.975,17.966,17.965$, $17.982,17.984 ; \mathrm{r}$ elements (top to bottom) 17.977, 17.967, 17.986.
W. bicostatus

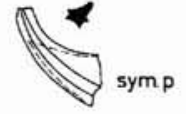

W ct sancticlairi
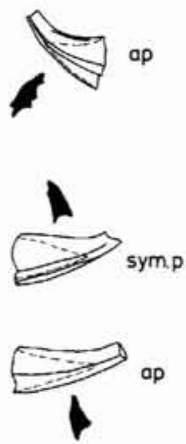

W. curvatus
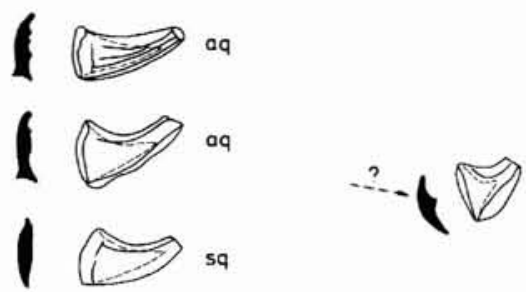
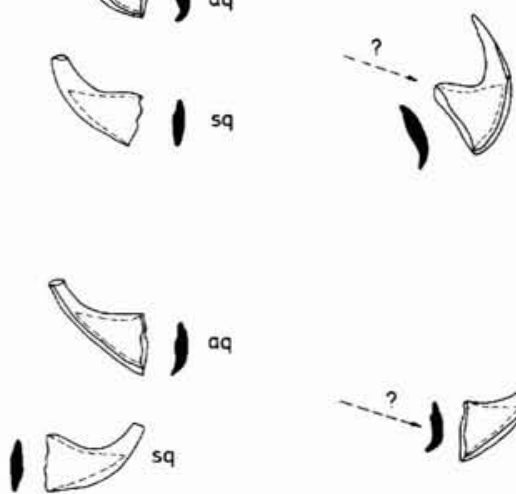

$a q$

sq

aq

\section{sq}


upper margin extending from the basal ridge to the apex. Below this lie less prominent shorter costae.

sq element. Refer to the description of Acodus curvatus sensu Branson \& Branson in Aldridge (1972, p. 162). The outer face is similar to that of the aq element in that it bears a single prominent costa close to its lower edge. In the sq element this costa is closer to the midline; the face is shallowly convex below and above this costa.

$r$ element. Morphologically transitional from the aq element, it is much shorter, apically bowed and more strongly recurved. The base and cusp are subequal in length; the former is inflated and upwardly tapering, the latter is broad and laterally compressed. The lower and upper margins are extended by broad keels, the lower is directed slightly inwardly and is broader at its base than the upper keel. Above the base the inner face of the cusp may be raised centrally and rarely possesses a low, inconspicuous costa (plate 21, fig. 12). The outer face is shallowly convex, slightly raised towards the lower margin. As in the other elements the base is entirely excavated.

Remarks. Cooper (1975, p. 996) reconstructed the apparatus of $W$. curvatus, and like Barrick (1977) suggested a continuous symmetry between the elements in the Walliserodus apparatus, applying the $\mathrm{M}$ and $\mathrm{S}$ element terminology of Sweet \& Schönlaub (1975). In the collections from Greenland, several separate transitions appear to be present: firstly, the sym. p-ap transition though this is not as well developed in this apparatus as in the apparatuses of $W$. biostatus and $W$. cf. $W$. sancticlairi; secondly the sym. p-aq-r transition, displayed through recurvature, increased apical bowing and twisting of the cusp and reduction of the inner, lower-lateral costa. In this respect the q elements retain both lowerlateral costae, whereas the ap element loses one. The sq element is not involved in these transitions, though it does show similar curvature to the aq elements. The multicostate aq specimens may be of a separate element, or an extreme development of the aq element.

Walliserodus debolti Serpagli (1967) contains elements similar to those of $W$. curvatus. These were noted by Cooper (1975, p. 996) to be extremely diverse and not exactly like those of $W$. curvatus. It is likely that $W$. debolti is the ancestor of $W$. curvatus.

Occurrence. Particularly common in the pre-Pterospathodus celloni Biozone strata of Washington Land. Outside Greenland Cooper (1975, p. 996) documents its range through the lower Silurian of Europe and North America.
Walliserodus $\mathrm{cf}$. W. sancticlairi Cooper, 1976 Plate 21, figs 16-24

cf. 1976 Walliserodus sancticlairi Cooper, p. 215, pl. 1, figs 8-11, 16-21.

Description. sym. $p$ element. Slender, suberect element with a long, laterally inflated base or shorter, shallowly proclined cusp. The upper margin of the base is more or less straight with a low keel along its length; the edge of the cusp is sharp. The lower margin is rounded and terminates laterally as two symmetrically disposed, lower-lateral costae. These are directed downwards and are keel-like, both extending from the basal corners and terminating at the base of the cusp. They diverge apically. The anterior edge of the cusp is sharp. Above the costae, the base is inflated slightly, with the lateral faces inclined towards the lower edge. The cusp is lenticular in cross section and may be slightly bowed. A narrow zone of faint basal wrinkles is visible on the scanning electron microscope, extending from the basal margin to approximately a quarter the height of the base. The basal margin is straight and basal surface entirely excavated. Basal cavity outline is illustrated in fig. 34 . White matter in all elements is restricted to the cusp tip, lateral costae and lower margin keels.

ap element. Morphologically transitional from the sym. p element; slender, erect with a narrow, tall base. Basal outline and cusp morphology are similar in both elements, though the cusp tends to be more strongly bowed in the aq. The upper and lower margins of the base are sharp and bear prominent keels, the edges of the cusp are also sharp. The inner face bears a single, inconspicuous costa which extends from the basal margin, runs obliquely to the midline and terminates at the posterior edge close to the base of the cusp. Below the costa the lateral face is shallowly convex and steeply inclined towards the lower margin; above the costa the face is less steeply inclined. The outer face is broadly convex. Basally the lateral faces bear a narrow zone of faint basal wrinkles, the basal margin is more or less straight and the basal surface is entirely excavated.

aq element. With a much broader base and stronger recurvature than the $\mathrm{p}$ element. The base is laterally inflated and tapers apically to a slender, biconvex, proclined cusp, this may be twisted inwardly. The upper and lower margins of the base are more or less straight and keeled; the lower is much broader and is directed inwardly. Basally the lower keel is much taller and decreases in height along the cusp. The lateral faces of the base are broadly convex and lack costae, each has a narrow zone of basal wrinkles which may be extended 
apically as faint microstriations. The basal margin is straight and the basal surface entirely excavated.

$s q$ element. Laterally compressed, bilaterally symmetrical cone, more strongly recurved than the aq element. Upper and lower margins of the base are sharp, and the lower bears a prominent keel. The cusp is lenticular in cross section with shallowly biconvex lateral faces. These bear a narrow zone of basal wrinkles which may be extended centrally as faint microstriations. The basal margin is straight and entirely excavated.

$r$ element. Short, highly recurved version of the aq element with a broad, short base which tapers rapidly, apically to a slender, biconvex cusp which may be twisted inwards. The upper margin of the base is sharp, the lower margin bears a prominent keel, directed slightly inwards. Apically the keel decreases in height along the edge of the cusp. The inner face is convex and smooth. The outer has a central inflated area, which tapers apically, terminating at the base of the cusp. A low inconspicuous costa, terminating at the base of the cusp, extends obliquely from close to the lower-basal corner, migrates to the lower margin and terminates level with the base of the cusp. A narrow zone of basal wrinkles passes around the base and, as in the other elements, extends centrally as an area of faint microstriations. The basal margin is straight, and the basal surface is entirely excavated.

Remarks. The apparatus of this species contains typically thin walled cones with weakly costate p elements and laterally acostate $q$ elements. The sym. p element is distinguished from its counterpart in other Walliserodus species in having lower costae that are directed downwards and no upper lateral costae. The $q$ and $r$ elements are characterised by their basal outline and biconvex slender cusp.

W. sancticlairi (Cooper, 1976) consists of slender coniform elements with similar basal outline and cusp cross-section to elements in $W$. cf $W$. sancticlairi. Differences in the costae of the sym. p element and the laterally acostate $q$ elements allow the separation of these species. Cooper (1976) did not describe an r element. Barrick (1977, pl. 1, fig. 11) reconstructed the apparatus of $W$. sancticlairi as containing a compressed element with a prominent lateral costa and tall lowermargin keel along with slender elements. The former is not included by Cooper (1976) or in this work. The prominent costa is more typical of elements of $W$. curvatus, and it would appear that Barrick's reconstruction contains elements from more than one species.

Occurrence. Particularly abundant in the Pterospathodus celloni and P. amorphognathoides Biozone strata of
Washington Land; with additional specimens of similar age from the rest of North Greenland.

\section{Ordovician conodont systematic palaeontology}

\section{Genus Aphelognathus Branson, Mehl \& Branson, 1951}

1951 Aphelognathus Branson, Mehl \& Branson, p. 9. 1951 Zygognathus Branson, Mehl \& Branson, p. 11.

Type series. Aphelognathus grandis Branson, Mehl \& Branson, 1951.

Diagnosis. Refer to Sweet (1979, p. 55).

Remarks. The apparatus was reconstructed by Sweet (1979) and confirmed by Barnes et al. (1979); it is characterised by the Pa element which has a prominent gap just anterior of the cusp. The remaining elements are similar to their counterparts in Oulodus and in the darkened specimens of the Greenland collection are difficult to separate.

\section{Aphelognathus pyramidalis (Branson, Mehl \&}

Branson, 1951)

Plate 22, figs 1-5

*1951 Zygognathus pyramidalis Branson, Mehl \& Branson, p. 12, pl. 3, figs 10-16, 21

p1951 Trichonodella undulata? Branson, Mehl \& Branson, p. 14, pl. 3, figs 24-26; pl. 4, fig. 14.

?1951 Microcoelodus panderi Branson, Mehl \& Branson, p. 16, pl. 4, fig. 12 .

p1951 Aphelognathus grandis Branson, Mehl \& Branson, p. 9, pl. 2, figs $11,13,14$ only.

1951 Zygognathus plebia Branson, Mehl \& Branson, p. 12 , pl. 3, figs 22,23 ; pl. 4 , figs $1-9$.

1951 Aphelognathus acutidentata Branson, Mehl \& Branson, p. 9, pl. 2, figs 15, 16.

1981a Aphelognathus pyramidalis; Sweet, p. 47, Aphelognathus pl. 3, figs 1-6.

Holotype. Zygognathus pyramidalis Branson, Mehl \& Branson, 1951, p. 12, pl. 3, fig. 21. Locality 1844 of Branson et al. (1951), Upper Ordovician (Richmondian stage) of Indiana.

Diagnosis. The original diagnosis was emended by Sweet (1981a, p. 47).

Remarks. A. pyramidalis is distinguished from other species of Aphelognathus in having a characteristic, angulate $\mathrm{Pa}$ element which possesses a broadly flaring 
lower margin and short rudimentary denticles on its posterior process.

Occurrence. Elements were recovered from the Tures $\varnothing$ Formation in Peary Land.

\section{Aphelognathus sp.}

Plate 22, fig. 6

Description. Pa element. Angulate, comprising a prominent posteriorly inclined cusp, a long, deep, anterior process and a shorter, downwardly inclined, posterior process. The upper edge of the anterior process is straight, bearing six short, triangular denticles; separated from the cusp by a narrow gap. The posterior process bears five similar denticles. The lower edge is arched upwards beneath the cusp at an angle of $160^{\circ}$. The basal cavity is a narrow groove along the entire length of the element.

Remarks. A single thermally mature specimen was recovered from GGU 274724 in the Tures $\varnothing$ Formation (fig. 9). This is referred to Aphelognathus due to the narrow gap in the denticulation, just anterior to the cusp. This specimen is similar to Spathognathodus elibatus Pollock, Rexroad \& Nicoll (1970), differing in the straight upper edge of the anterior process.
Genus Belodina Ethington, 1959

Type species. Belodus compressus Branson \& Mehl, 1933b. Senior subjective synonym of Belodus grandis Stauffer.

Diagnosis. Refer to Sweet (1979, p. 58).

Belodina aff. B. confluens Sweet, 1979

Plate 22, figs 14-15

aff. 1979 Belodina confluens Sweet, p. 59, pl. 5, figs 10, 17; pl. 6, fig. 9.

Description. Compressiform rastrate element. Laterally compressed with a broad basal margin extending as a well developed heel. Cusp long and recurved, the upper edge bears three tall, almost completely fused denticles, the lower edge is narrow and rounded. The inner face bears a narrow groove extending from a central basal notch, running close to the base of the denticles and subparallel to the posterior edge of the cusp. Below the groove the lateral face is slightly inflated, the lower edge is compressed into a rudimentary keel. The outer face is smooth, lacking a furrow. The entire basal surface is excavated, the cavity terminating close to the lower edge, beneath the first or second proximal denticle. All specimens are thermally mature and white matter is not distinguishable.

\section{Plate 22}

Figs 1-5. Aphelognathus pyramidalis Branson, Mehl \& Branson.

All specimens from GGU 256375, $\times 40$.

1, inner lateral view of Pb element; MGUH 17.987.

2 , inner lateral view of Pa element; MGUH 17.988.

3. posterior view of Sa element; MGUH 17.989.

4, posterior view of Sb element; MGUH 17.990.

5, inner lateral view of Sc element; MGUH 17.991.

Fig. 6. Aphelognathus sp.

6. inner lateral view of $\mathrm{Pa}$ element, $\times$ 40; MGUH 17.992.

Figs 7-10. Drepanoistodus suberectus (Branson \& Mehl). All specimens from GGU $256335, \times 40$.

7, lateral view of sym. p element; MGUH 17.993.

8, lateral view of sq element; MGUH 17.994.

9, inner lateral view of aq element; MGUH 17.995.

10 , lateral view of $\mathrm{r}$ element; MGUH 17.996.

Figs 11-13. Plegagnathus dartoni (Stone \& Furnish). All specimens $\times 40$.

11, lateral view of rastrate element; MGUH 17.997 from GGU 256337.

12, lateral view of rastrate element (?); MGUH 17.998 from GGU 254652.

13, lateral view of cordylodiform element (?); MGUH 17.999 from GGU 274726.

Figs 14-15. Belodina aff. B. confluens Sweet.

Specimens from GGU $245279, \times 40$.

14 , lateral view of rastrate element; MGUH 18.000 .

15 , lateral view of oistodiform element; MGUH 18.001 .

Figs 16-17. Pseudobelodina dispansa (Glenister). Specimens from GGU 245271, × 80 .

16 , lateral view of rastrate element; MGUH 18.002 .

17, lateral view of rastrate element; MGUH 18.003.

Figs 18-20. Pseudobelodina vulgaris vulgaris Sweet. All specimens $\times 60$.

18, lateral view of rastrate element; MGUH 18.004 from GGU 245273.

19 , lateral view of rastrate element; MGUH 18.005 from GGU 274726.

20 . lateral view of rastrate element; MGUH 18.006 from GGU 274726 . 

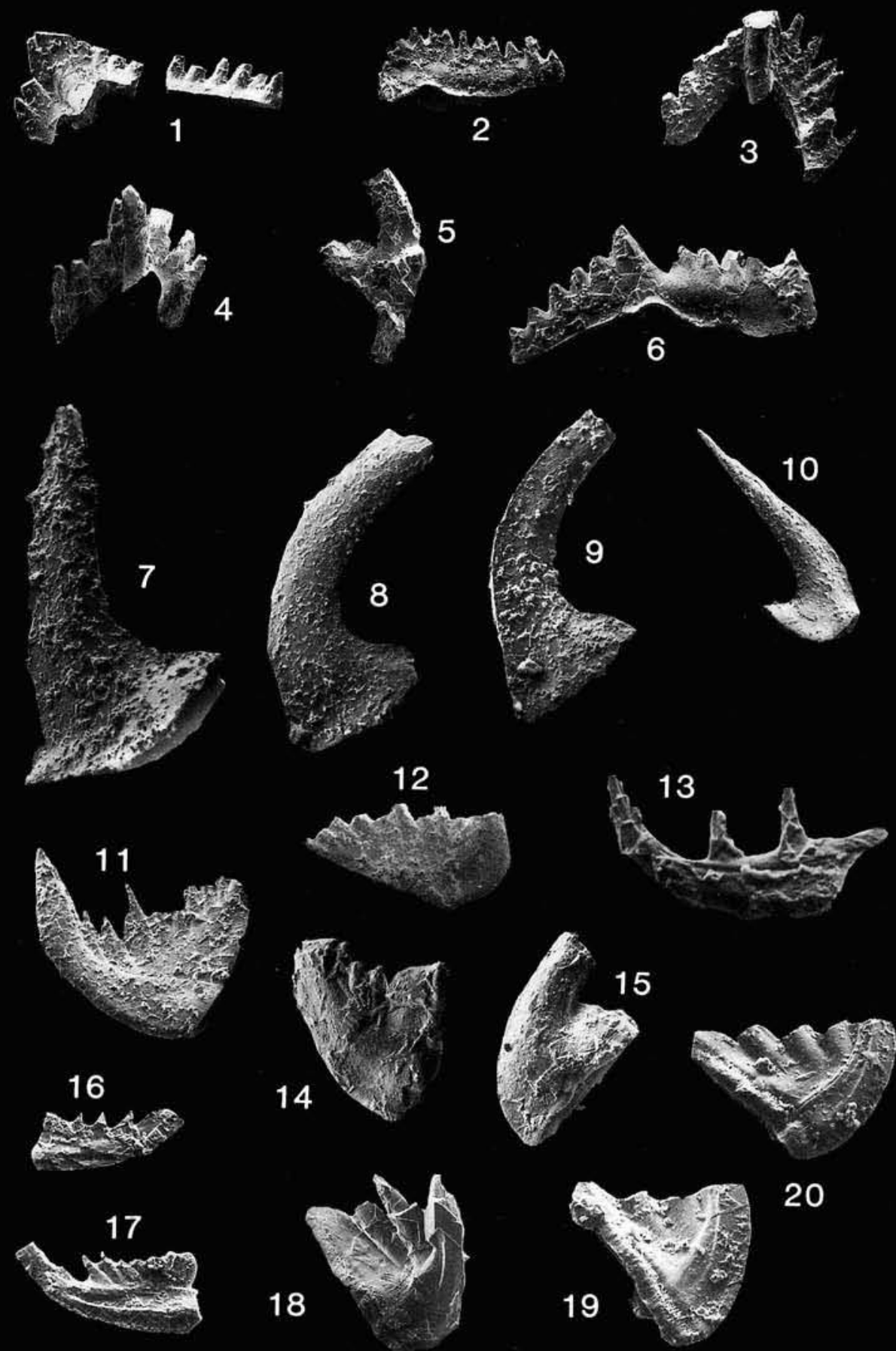

20 
Eobelodiniform element. Bilaterally symmetrical, strongly recurved element. The cusp is slender, long and strongly recurved. The upper and lower edges are sharp, the lateral faces shallowly convex and smooth. On the inner face a narrow groove extends from just above the centre of the basal margin to the apex, lying close to the posterior edge. The entire base is excavated with a cavity outline identical to the rastrate element.

Remarks. The upper edge of the rastrate element of $B$. confluens bears six denticles rather than the three of $B$. aff. B. confluens.

Occurrence. Found only in GGU 245271, 245279 and 254869 ; one compressiform rastrate and four eobelodiniform elements (figs 11, 13).

Genus Drepanoistodus Lindström, 1971

Type species. Oistodus forceps Lindström 1955, p. 574.

Diagnosis. Refer to Lindström (1971, p. 42).

\section{Drepanoistodus suberectus (Branson \& Mehl, 1933b) \\ Plate 22, figs 7-10}

?1930 Distacodus arcuatus Stauffer, p. 123, pl. 10, fig. 2.

*1933b Oistodus suberectus Branson \& Mehl, p. 111, pl. 9, fig. 7.

1933b Oistodus curvatus Branson \& Mehl, p. 110, pl. 9 figs $4,10,12$.

1933b Oistodus inclinatus Branson \& Mehl, p. 110, pl. 9, fig. 8 .

1955 Drepanodus homocurvatus Lindström, p. 563, pl. 2, figs $23,24,39$.

1966 Drepanodus suberectus; Bergström \& Sweet, p. 330 , pl. 35 , figs $22-27$, (includes synonymy to 1966).

1974 Drepanoistodus suberectus; Uyeno, p. 14, pl. 1, figs 5-9.

1975 Drepanoistodus suberectus; Sweet, Thompson \& Satterfield, pl. 1, figs 15-17.

1981 Drepanoistodus suberectus; McCracken \& Barnes, p. 77 , pl. 3, figs 1-6 (see for further synonymy).

Holotype. Oistodus suberectus Branson \& Mehl, 1933b, p. 111. From the Middle Ordovician, Plattin Formation, Jefferson County, Missouri.

Emended diagnosis. Apparatus quadrimembrate containing strongly compressed sym. p, aq, sq and $r$ elements with long curved cusps and short, laterally inflated bases.
Description. The sym. p, sq and $\mathrm{r}$ elements of this species have been described previously (see synonymy). An aq element, previously included in the taxa Oistodus curvatus Branson \& Mehl (1933b) and Drepanoistodus homocurvatus Lindström (1955b) is separated.

aq element. Basally similar to the other elements in the apparatus, it is slightly longer, has reduced lateral flaring and reduced extension of the basal corners. The cusp is proclined and sharply recurved from approximately one-third its height. Upper edge is sharp, lateral faces shallowly biconvex and the lower edge bears an inwardly directed, low costa; extending from the basal corner to the apex, decreasing in height along the upper sixth of the cusp.

Remarks. Drepanoistodus suberectus has been described as a trimembrate apparatus (see McCracken \& Barnes, 1981) consisting of drepanodontiform (= suberectiform and the $\mathrm{p}$ element herein), homocurvatiform ( $=\mathrm{q}$ elements herein) and oistodontiform ( $=\mathrm{r}$ element herein) elements. It is now possible to recognise aq and sq elements within the homocurvatiform element. Lindström (1971) noted the tendency for the elements of $D$. suberectus to become asymmetrical by bowing and twisting of the cusp. The aq element has an inwardly directed costa on the lower edge and a slightly different curvature from that of the sq element. The $\mathrm{r}$ element shows closer morphological affinities to the $p$ element than to the q elements; this is different from many coniform genera (e.g. Walliserodus, Panderodus and Dapsilodus) in which the aq and $r$ elements appear to be morphologically transitional.

Occurrence. Found in the uppermost Ordovician strata of Peary Land and Kronprins Christian Land.

Genus Plegagnathus Ethington \& Furnish, 1959

Type species. Belodina dartoni Stone \& Furnish, 1959, p. 220 , pl. 31 , fig. 15 .

Diagnosis. Refer to Sweet (1979, p. 66).

Plegagnathus dartoni Stone \& Furnish, 1959 Plate 22, figs 11-13

*1959 Belodina dartoni Stone \& Furnish, p. 220, pl. 31, fig. 15 .

1959 Plegagnathus dartoni; Ethington \& Furnish, p. 545 , pl. 73 , figs 6,7 .

1979 Plegagnathus dartoni; Sweet, p. 66, pl. 7, figs 28, 29.

?p1981 Plegagnathus dartoni; Nowlan \& Barnes, p. 23, pl. 7 , figs $13-15$; non figs 10,11 . 
Holotype. Belodina dartoni Stone \& Furnish, 1959, p. 220 , pl. 31, fig. 15. From the Bighorn Dolomite (late Ordovician, ?pre-Richmondian) of Johnson County, Wyoming.

Description. Refer to Sweet (1979, p. 66).

Remarks. This species is distinguished from $P$. nelsoni Ethington \& Furnish (1959) in having a greater number of closely spaced needle-like denticles on the upper edge of the plegagnathiform element. The cusp is untwisted and laterally broader, maintaining a constant thickness to its apex. $P$. nelsoni has fewer, broader denticles and a slightly more recurved plegagnathiform element. In the terminology employed herein, this element is equivalent to an sq element.

Occurrence. Found only in GGU 256337 and 256370 (figs 6, 7). Outside Greenland, Sweet $(1979$, fig. 3) recorded a range for $P$. dartoni of middle to mid-upper Richmondian.

\section{Genus Pristognathus Stone \& Furnish, 1959}

Type species. Pristognathus bighornensis, Stone \& Furnish, 1959 , p. 226.

Diagnosis. Refer to Sweet $(1979$, p. 67).

Remarks. Sweet (1979, p. 67) reconstructed the apparatus of the type species, as a seximembrate structure, similar to that of Oulodus. The $\mathrm{Pb}$ element of this apparatus is digyrate.

\section{Pristognathus bighornensis Stone \& Furnish,} 1959

Plate 23, figs 2-3

*1959 Pristognathus bighornensis Stone \& Furnish, p. 226 , pl. 32 , figs 7,8 .

1979 Pristognathus bighormensis; Sweet, p. 67, pl. 9 figs $1,4-6,9,10$ (see for full synonymy).

Diagnosis. Refer to Sweet $(1979$, p. 67).

Description. Pb element. Refer to that of Pristognathus bighornensis Stone \& Furnish $(1959$, p. 226) from which the Greenland specimens are indistinguishable.

Occurrence. Four specimens of the $\mathrm{Pb}$ element have been found in the Tures $\varnothing$ Formation at Odin Fjord, samples GGU 254652 and 254656 (fig. 10).
Genus Pseudobelodina Sweet, 1979

Type species. Belodina kirki Stone \& Furnish, 1959, p. 221.

Diagnosis. Refer to Sweet $(1979$, p. 68).

Pseudobelodina dispansa (Glenister, 1957)

Plate 22, figs 16-17

1957 Belodus dispansus Glenister, p. 729, pl. 88, figs 14,15 .

1959 Belodina dispansa; Stone \& Furnish, p. 220, pl. 31 , fig. 11.

*1979 Pseudobelodina dispansa; Sweet, p. 68, pl. 5, figs 6,$18 ; \mathrm{pl}$. 6 , figs $1,6,7,8$.

Hypotypes. Specimens OSU 34496-34501 inclusive from the Bighorn Group at OSU locality 75SD. Figured in Sweet $(1979$, pl. 5, figs 6, 18; pl. 6, figs 1, 6, 7, 8).

Diagnosis. Refer to Sweet (1979, p. 68).

Remarks. Two rastrate elements plus fragments are recorded from GGU 245271 (fig. 11) which have the characteristic furrow, upper margin denticulation and heel development of the ?p element proposed by Sweet (1979), these elements correspond to the sym. p elements proposed for Silurian genera.

Pseudobelodina vulgaris vulgaris Sweet, 1979

Plate 22, figs $18-20$

1959 Belodina profunda; Stone \& Furnish, p. 542, pl. 73 , fig. 5

*1979 Pseudobelodina vulgaris vulgaris Sweet, p. 71, pl. 5, figs $2-4$.

1981c Pseudobelodina vulgaris vulgaris; Sweet, p. 351, pl. 2, figs 2, 9, 10 (see for further synonymy)

1981 Belodina profunda; Nowlan \& Barnes, p. 12, pl. 7, figs 1-9, 12.

Syntypes. Pseudobelodina vulgaris vulgaris Sweet, 1979, pl. 71, pl. 5, figs 2-4. From the Bighorn Group (late Ordovician) of Sheridan County, Wyoming.

Diagnosis. Refer to that of Sweet $(1979$, p. 71$)$.

Description. Refer to Sweet (1979, p. 71). The Greenland specimens differ from those of Sweet in possessing more prominent lateral costae; individual elements are strongly recurved.

Remarks. Elements from Upper Ordovician of Kronprins Christian Land are characterised by long narrow 
heels, moderate curvature and two or three denticles. $P$. vulgaris ultima Sweet (1979) has a much reduced heel and four denticles on the rastrate (p? of Sweet, 1979) element.

Occurrence. Found in GGU 274724-274726 (fig. 9). Specimens include a tridenticulate rastrate element (3) and bidenticulate rastrate (3). Outside Greenland this species is recorded from the uppermost Richmondian of the U.S.A. (Sweet, 1981c, p. 352).

\section{Pseudobelodina sp.}

Plate 23, fig. 1

Description. Laterally compressed, strongly recurved, rastrate, coniform element. The base is broad and short, extended postero-basally as a long, slender heel. The upper margin of the base is straight, bearing three broad, fused denticles, which are inclined slightly towards the upper-basal corner. The cusp curves strongly upwards at its base, to be almost erect; the denticles lie subparallel to the upper edge of the cusp. The lower margin of the element is narrow and rounded, gently recurved from the basal corner. The basal margin is inclined apically towards the upper corner and the basal surface is entirely excavated. On the inner face two short parallel costae are situated towards the lower corner, extending, subparallel with the lower margin, and terminating at the base of the cusp. The outer face is shallowly convex and acostate.
Remarks. A single element in GGU 254652 (fig. 10) is morphologically similar to the P? element of Pseudobelodina torta Sweet $(1979, \mathrm{pl} .6$, fig. 23), but lacks the prominent lower-lateral costa. Elements of $P$. vulgaris vulgaris are also present in the sample, and the element may represent a P? element in this apparatus, but Sweet (1979) and Nowlan \& Barnes (1981) did not recognise a similar element in their large collections of $P$. vulgaris vulgaris.

\section{Genus Rhipidognathus Branson, Mehl \& Branson, 1951}

Type species. Rhipidognathus symmetricus Branson, Mehl \& Branson, 1951, p. 10.

Emended diagnosis. Apparatus seximembrate containing an angulate $(\mathrm{Pa})$ element, angulate $(\mathrm{Pb})$ element, a modified angulate (M) element and a symmetry transition series comprising palmate elements, alate (Sa), modified alate $(\mathrm{Sb})$, and bipennate $(\mathrm{Sc})$. All elements have a prominent cusp, tall triangular, partially fused denticles and a small laterally restricted basal cavity beneath the cusp.

\section{Rhipidognathus symmetricus Branson, Mehl \&} Branson, 1951

Plate 23, figs 49

*1951 Rhipidognathus symmetrica Branson, Mehl \& Branson, p. 10, pl. 2, figs 29-37; pl. 3, fig. 31 .

1951 Rhipidognathus sp. indeterminate Branson, Mehl \& Branson, pl. 3, fig. 29.

1951 Rhipidognathus paucidentata Branson, Mehl \& Branson, p. 10, pl. 3, fig. 30 .

\section{Plate 23}

Fig. 1. Pseudobelodina sp.

1 , lateral view of rastrate element, $\times 100 ;$ MGUH 18.007 from GGU 254652.

Figs 2, 3. Pristognathus bighornensis Stone \& Furnish. Specimens from GGU 254656, × 60 .

2, inner lateral view of $\mathrm{Pb}$ element; MGUH 18.008.

3, ?P element; MGUH 18.009.

Figs 4-9. Rhipidognathus symmetricus Branson, Mehl \& Branson.

All specimens from GGU 274540, $\times 60$.

4, inner lateral view of Pa element; MGUH 18.010.

5 , inner lateral view of $\mathrm{Pb}$ element; MGUH 18.011.

6 , inner lateral view of M element; MGUH 18.012.

7, posterior view of Sa element; MGUH 18.013.

8, posterior view of Sb element; MGUH 18.014.

9. inner lateral view of Sc element; MGUH 18.015.
Fig. 10. Genus and sp. indet. A.

10 , lateral view of element, $\times 40$; MGUH 18.016 from GGU 228959.

Fig. 11. Genus and sp. indet. B.

11 , lateral view of $\mathrm{Pb}$ element, $\times 60$; MGUH 18.017 from GGU 274758.

Fig. 12. Genus and sp. indet. C.

12 , lateral view of element, $\times 120$; MGUH 18.018 from GGU 254711.

Fig. 13. Genus and sp. indet. D.

13, upper view of Pa element, $\times$ 40; MGUH 17.631 from GGU 254827. 

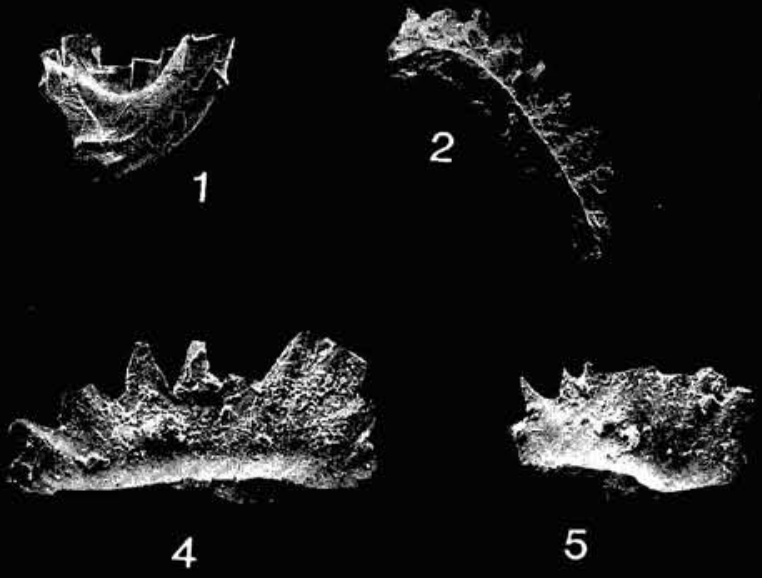

5
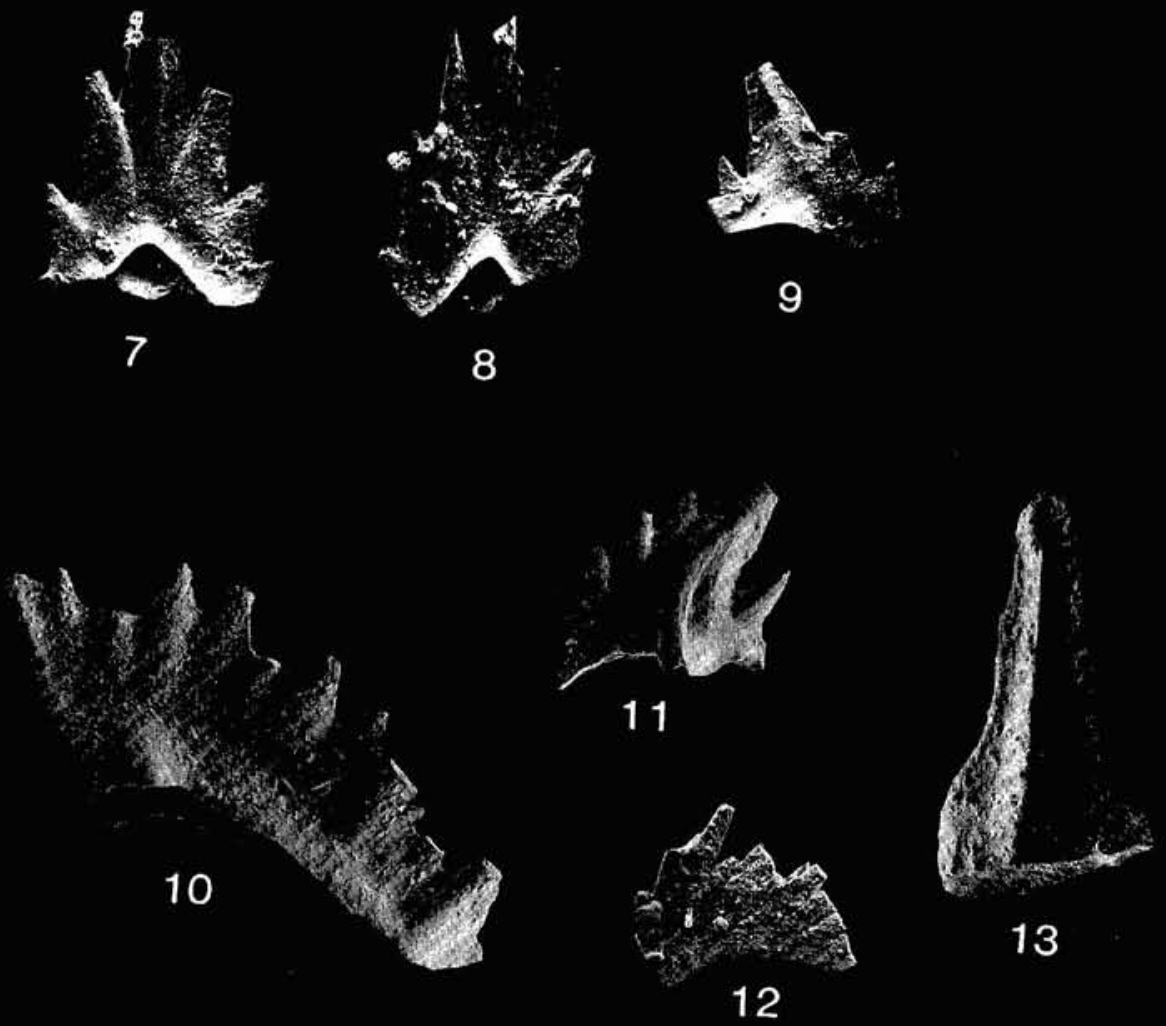
1951 Rhipidognathus curvata Branson, Mehl \& Branson, p. 10, pl. 3, figs 1-7.

1966 Rhipidognathus symmetrica; Bergström \& Sweet, p. 388.

1966 Rhipidognathus paucidentata; Schopf, p. 72, pl. 2, fig. 31 .

1968 Rhipidognathus symmetrica; Kohut \& Sweet, p. 1474 , pl. 185 , figs $21,22,25,26,29-31$ (includes synonymy to 1968 ).

1971 Rhipidognathus symmetricus; Sweet, Ethington \& Barnes, pl. 1, fig. 42.

1981 Rhipidognathus symmetricus; McCracken \& Barnes, p. 89 , pl. 4 , figs 45,46 .

Holotype. Rhipidognathus symmetrica Branson, Mehl \& Branson, 1951, p. 10, pl. 2, fig. 33. From the Whitewater Formation of Indiana, Richmondian in age.

Emended diagnosis. A species of Rhipidognathus with a $\mathrm{Pa}$ element with long anterior and short posterior processes and a broad inconspicuous cusp; M element with tall upwardly bowed cusp and short anterior processes of subequal length.

Description. Pa element. Angulate, straight to slightly bowed blade. An inconspicuous, posteriorly inclined cusp is situated close to the posterior tip of the blade, the anterior process is long and bears six to eight broad, partially fused, subequal denticles; the most proximal is almost completely fused to the cusp; the posterior process is much reduced and bears one to three smaller denticles. The lower edge is more or less straight, the inner margin of the cavity is straight, the outer is slightly inflated and projects downwards beneath the inner edge. The cavity is restricted to the area between the second proximal anterior denticle and the anterior edge of the cusp.

$\mathrm{Pb}$ element. Angulate and similar to the $\mathrm{Pa}$ it differs in having a central broad, prominent cusp. The anterior and posterior processes are subequal in length and each bears three or four small, partially fused denticles. Those on the anterior process are erect, those on the posterior tend to be slightly inclined towards the posterior. The basal cavity is narrow and groove-like with slightly flaring lateral lips beneath the cusp; (extending for a short distance to the anterior and posterior of the cusp).

$M$ element. Modified, angulate element with a tall, broad, slightly inwardly bowed, posteriorly inclined cusp and short anterior and posterior processes of similar length. Each process bears two almost completely fused, laterally compressed denticles, which are inclined distally. The lower edge of the element is straight to slightly concave, with a narrow, slit-like, restricted basal cavity.

Sa element. Alate element; the cusp is tall and cen- trally situated, the lateral processes subequal in length and each bearing two or three tall, partially fused denticles. These have broad bases, decrease in height and are inclined distally. The first proximal denticle on each process is almost completely fused to the cusp. The lower edge of the element is straight to slightly arched; the deep basal cavity is restricted beneath the cusp. Posteriorly the lower margin of the basal cavity is arched upwards.

Sb element. Modified tertiopedate element, lacking a posterior process, is almost identical to the Sa element, except for the stronger, asymmetrical arching of the lower edge. The inner process bears only two denticles and is shorter than the outer process.

Sc element. Bipennate with a tall, broad, posteriorly inclined cusp. The anterior process is longer than the posterior bearing two broad, posteriorly inclined, partially fused denticles. The posterior process bears a single, small denticle, rarely two denticles. The lower edge of the element is straight to slightly arched; the basal cavity is restricted to and only slightly expanded beneath the cusp.

Remarks. Previous reconstructions of the $R$. symmetricus apparatus have been trimembrate, and the diagnosis has been emended to include the newly described elements.

Occurrence. Found sporadically throughout the Upper Ordovician sections of Peary Land to Wulff Land. Most abundant in GGU 274540 (fig. 4).

\section{Acknowledgements}

This work arises from a co-operative project on the Lower Palaeozoic micropalaeontology of North Greenland between the Geological Survey of Greenland and the Micropalaeontology Unit, Department of Geology, University of Nottingham.

Generalised section logs used in this work were measured and sampled by the following: H. A. Armstrong, J. M. Hurst, J. R. Ineson, J. F. Jepsen, P. D. Lane, J. E. Mabillard, J. S. Peel and A. T. Thomas. Full section details and field slips are held by the Geological Survey of Greenland in Copenhagen.

The author wishes to express his gratitude to R. J. Aldridge for his supervision of this work, for making available his personal reprint and research collections and for many suggestions for the improvement of the manuscript. Thanks are also expressed to the many officers of the Geological Survey of Greenland for their help in the field; J. R. Ineson, P. D. Lane, J. E. Mabillard and A. T. Thomas also supplied valuable assistance in collecting conodont samples. The author also wishes to express his gratitude to the many conodont workers and museum curators who willingly made available type specimens or provided reprints. In particular, Lennart Jeppsson 
provided specimens from his Gotland collections. Hans Schönlaub is thanked for helpful referee's comments.

J. S. Peel and M. Sønderholm (GGU) are thanked for their thorough revision of the introductory sections and for the preparation of diagrams later drawn by Bente Thomas.

The use of processing and photographic facilities at the University of Nottingham and the University of Newcastle upon
Tyne are acknowledged. Technical and secretarial assistance was provided by L. Green, A. Swift, S. Hall, J. Wilkinson, D. Jones and E. Walton and the Geological Survey of Greenland.

Financial support from the N.E.R.C., from the Geological Survey of Greenland and the British Micropalaeontological Society is acknowledged.

\section{References}

Aldridge, R. J. 1972: Llandovery conodonts from the Welsh Borderland. Bull. Br. Mus. nat. Hist. (Geol.) 22, 127-231.

Aldridge, R. J. 1974: An amorphognathoides zone conodont fauna from the Silurian of the Ringerike area, South Norway. Norsk. geol. Tidsskr. 54, 295-303.

Aldridge, R. J. 1975: The stratigraphic distribution of conodonts in the British Silurian. J. geol. Soc. Lond. 131, 607618.

Aldridge, R. J. 1976: Comparison of macrofossil communities and conodont distribution in the British Silurian. Spec. Pap. Geol. Ass. Can. 15, 91-104.

Aldridge, R. J. 1979: An Upper Llandovery conodont fauna from Peary Land, eastern North Greenland, Rapp. Grønlands geol. Unders, 91, 7-23.

Aldridge, R. J. 1982: A fused cluster of coniform conodont elements from the late Ordovician of Washington Land, western North Greenland. Palaeontology 25, 425-431.

Aldridge, R. J. 1985: Conodonts of the Silurian System from the British Isles. In Higgins, A. C. \& Austin, R. L. (edit.) A stratigraphical index of conodonts, 68-93, Chichester: Ellis Horwood.

Aldridge, R. J. \& Armstrong, H. A. 1982: Conodont biostratigraphy of Silurian carbonate sequences in North Greenland. Unpublished int. report, Grønlands geol. Unders.

Aldridge, R. J. \& Mabillard, J. E. 1981: Local variations in the distribution of Silurian conodonts; an example from the amorphognathoides interval of the Welsh Basin. In Neale, J. W. \& Brasier, M. D. (edit.) Microfossils from recent and fossil shelf areas, 10-17. Chichester: Ellis Horwood.

Aldridge, R. J. \& Mohamed, I. 1982: Conodont biostratigraphy of the early Silurian of the Oslo region. In I.U.G.S. Subcommission on Silurian Stratigraphy Field Meeting, Oslo region. Worsley, D. (edit.) Paleont. Contr. Univ. Oslo 278 , 109-120.

Aldridge, R. J., Dorning, K. J. \& Siveter, D. J. 1981: Distribution of microfossil groups across the Wenlock Shelf of the Welsh Basin. In Neale, J. W. \& Brasier, M. D. (edit.) Microfossils from recent and fossil shelf seas, 18-29. Chichester: Ellis Horwood.

Armstrong, H. A. 1983: The early Silurian conodont micropalaeontology of the North Greenland carbonate platform. Unpublished Ph.D. thesis, University Nottingham.
Armstrong, H. A. 1986a: Preliminary report on the Silurian conodont faunas of central North Greenland. Unpublished int. report, Grønlands geol. Unders.

Armstrong, H. A. 1986b: Report on the Silurian conodont biostratigraphy and CAI of western North Greenland. Unpublished int. report, Grønlands geol. Unders.

Armstrong, H. A. 1986c: Conodont biostratigraphy of the Washington Land Group, North Greenland. Part III. Unpublished int. report, Grønlands geol. Unders.

Armstrong, H. A. \& Lane, P. D. 1981: The Un-named Silurian(?) dolomite Formation, Børglum Elv, central Peary Land. Rapp. Grønlands geol. Unders. 106, 29-34.

Barnes, C. R. 1974: Ordovician conodont biostratigraphy of the Canadian Arctic. In Aitken, J. D. \& Glass, J. D. (edit.) Symposium on geology of the Canadian arctic, 221-240. Toronto: Can. Soc. Petrol. Geol., Geol. Ass. Can.

Barnes, C. R. 1977: Ordovician conodonts from the Ship Point and Bad Cache Rapids Formations, Melville Peninsula, southeastern district of Franklin. Bull. geol. Surv. Can. 269, 99-119.

Barnes, C. R. \& Fåhræus, L. E. 1975: Provinces, communities, and the proposed nektobenthic habit of Ordovician conodontophorids. Lethaia 8, 133-149.

Barnes, C. R. \& McCracken, A. D. 1980: Anticosti Island, Quebec as a proposed stratotype for the base of the Silurian: the conodont evidence. [abstract] Palaeontological Association, 1980, December.

Barnes, C. R. \& Munro, I. 1973: Middle and Upper Ordovician conodont faunas from Manitoba, Hudson Bay and Canadian Shield outliers. Abstr. geol. Soc. Am. 5, 297 only.

Barnes, C. R., Brideaux, W. W., Chamney, T. P. et al. 1974: Biostratigraphic determinations of fossils from the subsurface of the Northwest and Yukon territories. Pap. geol. Surv. Can. 74-11, 30 pp.

Barnes, C. R., Jackson, D. E. \& Norford, B. S. 1976: Correlation between Canadian Ordovician zonations based on graptolites, conodonts and benthic microfossils from key successions. In Bassett, M. G. (edit.) The Ordovician System, 209-226. Univ. Wales Press.

Barnes, C. R., Telford, P. G. \& Tarrant, G. A. 1978: Ordovician and Silurian conodont biostratigraphy, Manitoulin Island and Bruce Peninsula, Ontario. Spec. Pap. Michigan Basin geol. Soc. 3, 63-71. 
Barnes, C. R., Kennedy, D. J., McCracken, A. D., Nowlan, G. S. \& Tarrant, G. A. 1979: The structure and evolution of Ordovician conodont apparatuses. Lethaia 12, 125-151.

Barrick, J. E. 1977: Multielement simple-cone conodonts fron the Clarita Formation (Silurian), Arbuckle Mountains, Oklahoma, Geol. Palceont. 11, 47-68.

Barrick, J. E. \& Klapper, G. 1976: Multielement Silurian (late Llandoverian-Wenlockian) conodonts of the Clarita Formation, Arbuckle Mountains, Oklahoma, and phylogeny of Kockelella. Geol. Palaront. 10, 59-100.

Bergström, S. M. 1971: Conodont biostratigraphy of the Middle and Upper Ordovician of Europe and east North America. In Sweet, W. C. \& Bergström, S. M. (edit.) Symposium on conodont biostratigraphy. Mem. geol. Soc. Am. 127, 83-161.

Bergström, S. M. 1973: Ordovician conodonts. In Hallam, A. (edit.) Atlas of palaeobiogeography, 47-58. Amsterdam: Elsevier.

Bergström, S. M. \& Sweet, W. C. 1966: Conodonts from the Lexington Limestone (Middle Ordovician) of Kentucky and its lateral equivalents in Ohio and Indiana. Bull. Am. Paleont. 50, 271-441.

Berry, W. B. N. \& Boucot, A. J. 1973: Glacio-eustatic control of Late Ordovician - Early Silurian platform sedimentation and faunal changes. Bull. geol. Soc. Am. 84, 275-284.

Bischoff, G. C. O. 1986: Early and middle Silurian conodonts from midwestern New South Wales. Cour. Forsch. Inst. Senckenberg 89, 1-337.

Bischoff, G. C. O. \& Sannemann, D. 1958: Unterdevonische Conodonten aus dem Frankenwald. Notizbl. Hess. Landesamtes Bordenforsch. Wiesbaden 86, 87-110.

Bjerreskov, M. 1981: Silurian graptolites from Washington Land, western North Greenland. Bull. Grønlands geol. Unders. 142, $52 \mathrm{pp}$.

Branson, E. B. \& Branson, C. C. 1947: Lower Silurian conodonts from Kentucky. J. Paleont. 21, 549-556.

Branson, E. B. \& Mehl, M. G. 1933a: Conodonts from the Bainbridge (Silurian) of Missouri. Univ. Mo. Stud. 8, 39-53.

Branson, E. B. \& Mehl, M. G. 1933b: Conodonts from the Plattin (Middle Ordovician) of Missouri. Univ. Mo. Stud. 8, 101-119.

Branson, E. B. \& Mehl, M. G. 1941: New and little known Carboniferous conodont genera. J. Paleont. 15, 97-106.

Branson, E. B., Mehl, M. G. \& Branson, C. C. 1951: Richmond conodonts of Kentucky and Indiana. J. Paleont. 25, 1-17.

Brideaux, W. W., Chamning, T. P., Dunay, R. E., et al. 1975: Biostratigraphic determinations of fossils from the subsurface of the Districts of Franklin and Mackenzie. Pap. geol. Surv. Can. 74-39, 19 pp.

Brooks, M. \& Druce, E. L. 1965: A Llandovery conglomeratic limestone in Gullet Ouarry, Malvern Hills, and its conodont fauna. Geol. Mag. 102, 370-382.

Bultynck, P. 1970: Revision stratigraphique et paléontologique (Brachiopodes et Conodontes) de la coupe type du Couvinian. Mém. Inst. Géol. Univ. Louvain 25, 152 pp.

Carnes, J. B. 1975: Conodont biostratigraphy in the lower Middle Ordovician of the Western Appalachian thrust-beits in northeastern Tennessee. Unpublished Ph.D. thesis, 291 pp. Ohio State University, Columbus.

Christic, R. L. \& Ineson, J. R. 1979: Precambrian-Silurian geology of the G. B. Schley Fjord region, eastern Peary Land, North Greenland. Rapp. Gronlands geol. Unders. 88, 63-71.

Christie, R. L. \& Peel, J. S. 1977: Cambrian and Silurian stratigraphy of Børglum Elv, Peary Land, eastern North Greenland. Rapp. Grønlands geol. Unders. 82, 48 pp.

Clark, D. L. 1981: Classification. In Robison, R. A. (edit.) Treatise on Invertebrate Paleontology, W (Supplement 2, Conodonta), W102-103. Geol. Soc. Am., Univ. Kansas Press.

Clark, D. L. \& Ethington, R. L. 1966: Conodonts and biostratigraphy of the Lower and Middle Devonian of Nevada and Utah. J. Paleont. 40, 659-689.

Cocks, L. R. M. 1985: The Ordovocian-Silurian boundary. Episodes 8, 98-100.

Cocks, L. R. M., Woodcock, N. H., Rickards, R. B., Temple, J. T. \& Lane, P. D. 1984: The Llandovery series of the type area. Bull. Br. Mus. nat. Hist. (Geol.) 38, 131-182.

Cooper, B. J. 1974: New forms of Belodella (Conodonta) from the Silurian of Australia. J. Paleont. 48, 1120-1125.

Cooper, B. J. 1975: Multielement conodonts from the Brassfield Limestone (Silurian) of southern Ohio. J. Paleont. 49, 84-1008.

Cooper, B. J. 1976: Multiclement conodonts from the St. Clair Limestone (Silurian) of southern Illinois. J. Paleont. 50, 205-217.

Cooper, B. J. 1977a: Toward a familial classification of Silurian conodonts. J. Paleont. 51, 1057-1071.

Cooper, B. J. 1977b: Upper Silurian conodonts from the Yarangobilly Limestone, south-eastern New South Wales. Proc. roy. Soc. Vict. 89, 183-194.

Cooper, B. J. 1980: Toward an improved Silurian conodont biostratigraphy. Lethaia 13, 209-277.

Craig, W. W. 1969: Lithic and conodont succession of Silurian strata, Batesville district, Arkansas. Bull. geol. Soc. Amer. 80, 1621-1628.

Drygant, D. M. 1969a: [Stratigraphy and conodonts of the Silurian and Lower Devonian of Podolia.] Spec. Publ. Lvov Order of Lenin State Univ. Ivan Franks 128, 21 pp. (in Russian).

Drygant, D. M. 1969b: [Conodonts of the Kestevo, Kitaigorod and Muksha horizons of the Silurian of Podolia.] Paleont. Sb., Lvov Univ. 6, 49-56 (in Russian).

Drygant, D. M. 1974a: [About the stages of the development of conodonts in the Ordovician, Silurian and early Devonian of the Volyn-Podolian.] Paleont. Sb., Lvov Univ. 11, 85-90 (in Russian).

Drygant, D. M. 1974b: [Phenomenon of regeneration of conodonts in the Ordovician, Silurian and Lower Devonian of Volyn-Podolia.] Dopov. Akad. Nauk. URSR, B 3, 203-206 (in Russian).

Drygant, D. M. 1974c: [Simple conodonts of the Silurian and lowermost Devonian of the Volyn-Podolian area.] Paleont. Sb., Lvov Univ. 10, 64-70 (in Russian). 
Ethington, R. L. 1959: Conodonts of the Ordovician Galena Formation. J. Paleont. 33, 257-292.

Ethington, R. L. \& Clark, D. L. 1982: Lower and Middle Ordovician conodonts from the Ibex area, western Millard County, Utah. Brigham Young Univ. Geol. Stud. 28(2), 1-160.

Ethington, R. L. \& Furnish, W. M. 1959: Ordovician conodonts from northern Manitoba. J. Paleont. 33, 540-546.

Ethington, R. L. \& Furnish, W. M. 1962: Silurian and Devonian conodonts from the Spanish Sahara. J. Paleont. 36, 1253-1290.

Fåhraeus, L. E. \& Barnes, C. R. 1981: Conodonts from the Becscie and Gun River Formations (Lower Silurian) of Anticosti Island, Québec. In Lespérance, P. J. (edit.) Subcommission Silurian stratigraphy, Ordovician-Silurian Boundary. Field Meeting, Anticosti-Gaspé, Québec 1981, 2: Stratigraphy and Paleontology, 165-172.

Fisher, R. A., Corbet, A. S. \& Williams, C. B. 1943: The relation between the number of species and the number of individuals in a random sample of an animal population. $J$. Anim. Ecol. 12, 42-58.

Flajs, G. 1967: Conodontenstratigraphische Untersuchungen im Raum von Eisenerz, Nördliche Grauwackenzone, Mitt. Geol. Ges. Wien 59, 157-218.

Fortey, R. A. \& Peel, J. S. 1989: Stratigraphy and hystricurid trilobites of the Christian Elv Formation (Lower Ordovician) of western North Greenland. Rapp. Grønlands geol. Unders. 144, 5-15.

Fortey, R. A. \& Peel, J. S. in press: Early Ordovician trilobites and molluscs from the Poulsen Cliff Formation, Washington Land, western North Greenland. Bull. geol. Soc. Denmark.

Glenister, A. T. 1957: The conodonts of the Ordovician Maquoketa Formation in Iowa. J. Paleont. 31, 715-736.

Helfrich, C. T. 1978: A conodont fauna from the Keyser Limestone of Virginia and West Virginia. J. Paleont. 52, 11331142.

Helfrich, C. T. 1980: Late Llandovery - early Wenlock conodonts from the upper part of the Rose Hill and the basal part of the Mifflintown Formations, Virginia, West Virginia, and Maryland. J. Paleont. 54, 557-569.

Higgins, A. K., Ineson, J. R. Peel, J. S., Surlyk, F. \& Sønderholm, M. in press: The Franklinian basin in North Greenland. In Trettin, H. P. (edit.) The Innuitian region. The geology of North America. E. Ottawa: Geol. Surv. Canada.

Hurst, J. M. 1979: Uppermost Ordovician and Silurian geology of north-west Peary Land, North Greenland. Rapp. Grønlands geol. Unders. 88, 41-51.

Hurst, J. M. 1980a: Paleographic and stratigraphic differentiation of Silurian carbonate buildups and biostromes of North Greenland. Bull. Am. Ass. Petrol. Geol. 64, 527-548.

Hurst, J. M. 1980b: Silurian stratigraphy and facies distribution in Washington Land and western Hall Land, North Greenland. Bull. Grønlands geol. Unders. 138, 95 pp.

Hurst, J. M. 1984: Upper Ordovician and Silurian carbonate shelf stratigraphy, facies and evolution, eastern North Greenland. Bull. Grønlands geol. Unders. 148, 73 pp.

Hurst, J. M. \& Peel, J. S. 1979: Late Proterozoic(?) to Silurian stratigraphy of southern Wulff Land, North Greenland. Rapp. Grønlands geol. Unders. 91, 37-56.

Hurst, J. M. \& Surlyk, F. 1980: Notes on the Lower Palaeozoic clastic sediments of Peary Land, North Greenland. Rapp. Grønlands geol. Unders. 99, 73-78.

Hurst, J. M. \& Surlyk, F. 1982: Stratigraphy of the Silurian flysch sequence of North Greenland. Bull. Grønlands geol. Unders. 145, $120 \mathrm{pp}$.

Hurst, J. M. \& Surlyk, F. 1983a: Initiation, evolution, and destruction of an Early Palcozoic carbonate shelf, eastern North Greenland. J. Geol. 91, 671-691.

Hurst, J. M. \& Surlyk, F. 1983b: Depositional environments along a carbonate ramp to slope transition in the Silurian of Washington Land, North Greenland. Can. J. Earth Sci. 20, 473-499.

Igo, H. \& Koike, T 1968: Ordovician and Silurian conodonts from the Langkawi Islands, Malaysia, Part II. Geol. Palacont. S. E. Asia 4, 1-21.

Ineson, J. R., Peel, J. S. \& Smith, M. P. 1986: The Sjælland Fjelde Formation: a new Ordovician formation from eastern North Greenland. Rapp. Grønlands geol. Unders. 132, 27-37.

Jentzsch, I. 1962: Conodonten aus dem Tentaculitenknollenkalk (Unterdevon) in Thüringen. Geologie 11, 961-985.

Jeppsson, L. 1969: Notes on some Upper Silurian multielement conodonts. Geol. Fören. Stockh. Förh. 91, 12-24.

Jeppsson, L. 1972: Some Silurian conodont apparatuses and possible conodont dimorphism. Geol. Palaeont. 6, 51-69.

Jeppsson, L. 1974: Aspects of late Silurian conodonts. Fossils and Strata 6, 54 pp.

Jeppsson, L. 1979a: Conodont element function. Lethaia 12, 153-171.

Jeppsson, L. 1979b: Conodonts. In Jaanusson, V. Laufeld, S. \& Skoglund, R. (edit.) Lower Wenlock faunal and floral dynamics - Vattenfallet section, Gotland. Sver. geol. Unders. C 762, 225-248.

Jones, O. T. 1925: Geology of the Llandovery district. Part 1: the southern area. Quart. J. geol. Soc. Lond. 81, 344-388.

Klapper, G. \& Murphy, M. A. 1975: Silurian - Lower Devonian conodont sequence in the Roberts Mountains Formation of central Nevada. Univ. Calif. Publs Geol. Sci. 111, 62 pp.

Klapper, G. \& Philip, G. M. 1971: Devonian conodont apparatuses and their vicarious skeletal elements. Lethaia 4, 429452.

Klapper, G. \& Philip, G. M. 1972: Familial classification of reconstructed Devonian conodont apparatuses. Geol. Palacont. Sonderbd 1, 97-114.

Kohut, J. J. \& Sweet, W. C. 1968: The American Upper Ordovician standard X. Upper Maysville and Richmond conodonts from the Cincinnati region of Ohio, Kentucky and Indianna. J. Paleont. 42, 1456-1477.

Kurtz, V. E. \& Miller, J. F. 1981: Early Ordovician conodont faunas from central East Greenland. Abstr. geol. Soc. Am. 13, 285 only.

Kuwano, Y. 1976: Finding of Silurian conodont assemblages from the Kurosegawa tectonic zone in Shikoku, Japan. Mem. natn. Sci. Mus. Tokyo 9, 17-22. 
Kuwano, Y. 1982: Element composition of some Silurian Ozarkodinids. In Jeppsson, L. \& Löfgren, A. (edit.) Third European Conodont Symposium (Ecos III) Abstracts. Publ. Inst. Miner. Paleont. Quat. Geol. Univ. Lund 238, 1 only.

Lane, P. D. 1972: New trilobites from the Silurian of north-east Greenland, with a note on trilobite faunas in pure limestones. Palaeontology 15, 336-364.

Larsen, P.-H. \& Escher, J. C. 1985: The Silurian turbidite sequence of the Peary Land Group between Newman Bugt and Victoria Fjord, western North Greenland. Rapp. Grønlands geol. Unders. 126, 47-67.

Larsen, P.-H. \& Escher, J. C. 1987: Additions to the lithostratigraphy of the Peary Land Group (Silurian) in western and central North Greenland. Rapp. Grønlands geol. Unders. 133, 65-80.

Laufeld, S. 1974: Reference localities for paleontology and geology in the Silurian of Gotland. Sveriges Geologiska Undersökning, C705, 172 pp.

Le Fèvre, J., Barnes, C. R. \& Tixier, M. 1976: Paleoecology of late Ordovician and early Silurian Conodontophorids, Hudson Bay Basin. Spec. Pap. Geol. Ass. Can. 15, 68-89.

Lenz, C. A. \& McCracken, A. D. 1982: The OrdovicianSilurian boundary, northern Canadian Cordillera, graptolite and conodont correlation. Can. J. Earth Sci. 11, 70-78.

Liebe, R. M. \& Rexroad, C. B. 1977: Conodonts from Alexandrian and early Niagaran rocks in the Joliet, Illinois area. J. Paleont. 51, 844-857.

Lindström, M. 1955: Conodonts from the lowermost Ordovician strata of south-central Sweden. Geol. Fören. Stockh. Förh. 76, 517-614.

Lindström, M. 1959: Conodonts from the Crug Limestone (Ordovician, Wales). Micropalaeontology 5, 427-452.

Lindström, M. 1964: Conodonts. Amsterdam: Elsevier. 196 pp.

Lindström, M. 1970: A suprageneric taxonomy of the conodonts. Lethaia 3, 427-445.

Lindström M. 1971: Lower Ordovician conodonts of Europe. Mem. geol. Soc. Am. 127, 21-61.

Link, A. G. \& Druce, A. C. 1972: Ludlovian and Gedinnian conodont stratigraphy of the Yass Basin, New South Wales. Bull. Bur. Miner. Res. Aust. 134, 136 pp.

Löfgren, A. 1978: Arenigian and Llanvirnian conodonts from Jämtland, northern Sweden. Fossils and Strata 13, 129 pp.

Mabillard, J. E. M. \& Aldridge, R. J. 1983: Conodonts from the Coralliferous Group (Silurian) of Marloes Bay; Southwest Dyfed, Wales. Geol. Palaront. 17, 29-35.

Mabillard J. E. M. \& Aldridge, R. J. 1985: Microfossil distribution across the base of the Wenlock Series in the type area. Palaeontology 28, 89-100.

Manara, C. \& Vai, G. B. 1970: La sezione e i conodonti del costone sud de M. Rauchkofel (Paleozoico, Alpi Carniche). G. Geol. (Bologna Mus. Geol.) (2A), 36 (1968), 441-503.

Mashkova, T. V. 1970: [Conodont zones in the Silurian of the Elegest River region,, Tuva.] Trudy Akad. Nauk SSSR, Sib. Otd. Inst. Geol. Geofiz. 71, 8-21.

Mashkova, T. V. 1977: [New conodonts of the amorphognathoides zone from the Lower Silurian of Podolia.] Paleont. Zh. 1977(4), 127-131 (in Russian).
Mashkova, T. V. 1979: [New conodonts from Central Siberia.] Paleont. Zh. 1979(2), 98-105 (in Russian).

Matthews, S. C. 1973: Notes on open nomenclature and on synonymy lists. J. Paleont. 16, 713-719.

Mayr, U., Uyeno, T. T. \& Barnes, C. R. 1978: Subsurface stratigraphy, conodont zonation, and organic metamorphism of the Lower Paleozoic succession, Bjorne Penninsula, Ellesmere Island, District of Franklin. Pap. geol. Surv. Can. 78-1A, 393-398.

Mayr, U., Uyeno, T. T., Tipnis R. S. \& Barnes, C. R. 1980: Subsurface stratigraphy and conodont zonation of the Lower Paleozoic succession, Arctic Platform, southern Arctic Archipelago. Pap. geol. Surv. Can. 80-1A, 209-215.

McCracken, A. D. \& Barnes, C. R. 1981: Conodont biostratigraphy and paleoecology of the Ellis Bay Formation, Anticosti Island, Quebec, with special reference to the Late Ordovician - Early Silurian chronostratigraphy and the systemic boundary. Bull. geol. Surv. Can. 329, 51-134.

McCraken, A. D. \& Nowlan, G. S. 1984: Conodonts from Ordovician-Silurian boundary strata, Whittacker Formation, Avalanche Lake, Mackenzie Mountains, Northwest territories, Canada. Geol. Soc. Am. 16, 179.

McCracken, A. D., Nowlan, G. S. \& Barnes, C. R. 1980: Gamachignathus, a new multielement conodont genus from the latest Ordovician, Anticosti Island, Quebec. Pap. geol. Surv. Can. 80-1C, 103-112.

McGill, P. C. 1974: The stratigraphy and structure of the Vendom Fjord area. Bull. Can. Soc. Petrol Geol. 22, 361386.

Miller, R. H. 1972: Silurian conodonts from the Llano region, Texas. J. Paleont. 46, 556-564.

Miller, R. H. 1976: Revision of Upper Ordovician, Silurian and Lower Devonian stratigraphy, southwestern Great Basin. Bull. geol. Soc. Am. 87, 961-968.

Miller, R. H. 1978: Early Silurian to early Devonian conodont biostratigraphy and depositional environments of the Hidden Valley Dolomite, Southeast California. J. Paleont. 52, 323-344.

Miller, J. F. \& Kurtz, V. E. 1979: Reassignment of the Dolomite Point Formation of East Greenland from the Middle Cambrian(?) to the Lower Ordovician based on conodonts. Abstr. geol. Soc. Amer. 11, 480 only.

Mirza, K. 1976: Late Ordovician to late Silurian stratigraphy and conodont biostratigraphy of the Eastern Canada Arctic Island. Unpublished M.Sc. thesis, University of Waterioo.

Morrow, D. W. 1973: Stratigraphy and sedimentology of Lower Paleozoic formations near and on Grinnell Penninsula, Devon Island, Northwest Territories. Unpublished Ph.D. thesis, Univ. of Texas, Austin.

Moskalenko, T. A. 1970: [Conodont zones in the Silurian of the Elegest River region, Tuva.] Trudy Akad. Nauk SSSR Sib. Otd. Inst. Geol. Geofiz. 71, 8-21.

Mostler, H. 1967: Conodonten aus dem tiefern Silur der Kitzbuhler Alpen (Tirol). Annln Naturh. Mus. Wien 71, 295303.

Murphy, M. A., Dunham, J. B., Berry, W. B. N. \& Matti, J. C. 1979: Late Llandovery unconformity in central Nevada. Brigham Young Univ. Geol. Stud. 26, 21-36. 
Nicoll, R. S. 1977: Conodont apparatuses in an Upper Devonian palaeoniscoid fish from the Canning Basin, Western Australia. J. Australian Geol. Geophys. 2, 217-228.

Nicoll, R. S. \& Rexroad, C. R. 1969: Stratigraphy and conodont paleontology of the Salamonie Dolomite and Lee Creek Member of the Brassfield Limestone (Silurian) in S. E. Indiana and adjacent Kentucky. Bull. Indiana geol. Surv. 40, 75 pp.

Norby, R. D. 1976: Conodont apparatuses from Chesterian (Mississippian) strata of Montana and Illinois. Unpublished Ph.D. thesis. Graduate College, University of Illinois, Urbana, Champaign.

Norford, B. S. 1972: Silurian stratigraphic section at Kap Tyson, Offley $\emptyset$ and Kap Schuchert. Meddr Grønland 195(2), $40 \mathrm{pp}$.

Norford, B. S. \& Orchard, M. J. 1983: Early Silurian age rocks hosting lead-zinc mineralization at Howard Pass, Yukon Territory and district of Mackenzie; local biostratigraphy of Road River formation and Earn Group. Pap. Geol. Surv. Can. 83-18, 35 pp.

Nowlan, G. S. 1981: Late Ordovician - Early Silurian conodont biostratigraphy of the Gaspé Peninsula - a preliminary report. In Lespérance, P. J. (edit.) Subcommission on Silurian stratigraphy, Ordovician-Silurian Boundary. Field meeting, Anticosti-Gaspé, Québec 1981, 2: Stratigraphy and Paleontology, 257-291.

Nowlan, G. S. 1983: Early Silurian conodonts of eastern Canada. Fossils and Strata, 15, 95-110.

Nowlan, G. S. \& Barnes, C. R. 1981: Late Ordovician conodonts from the Vauréal Formation, Anticosti Island, Quebec. Bull. geol. Surv. Can. 329, 1-49.

Orchard, M. J. 1980: Upper Ordovician conodonts from England and Wales. Geol. Palceont. 14, 9-44.

Ovenshine, A. T. \& Webster, G. D. 1970: Age and stratigraphy of the Heceta Limestone in northern Sea Otter Sound, southeastern Alaska. Prof. Pap. U.S. geol. Surv. 700C, 170-174.

Over, D. J. \& Chatterton, B. D. E. 1987: Silurian conodonts from the southern Mackenzie Mountains, Northwest Territories, Canada. Geol. Paleont. 21, 1-49.

Peel, J. S. \& Hurst, J. M. 1980: Late Ordovician and early Silurian stratigraphy of Washington Land, western North Greenland. Rapp. Grønlands geol. Unders. 100, 18-24.

Peel, J. S. \& Smith, M. P. 1988: The Wandel Valley Formation (Early-Middle Ordovician) of North Greenland and its correlatives. Rapp. Grønlands geol. Unders. 137, 61-92.

Peel, J. S., Ineson, J. R., Lane, P. D. \& Armstrong, H. A. 1981: Lower Palaeozoic stratigraphy around Danmark Fjord, eastern North Greenland. Rapp. Grønlands Geol. Unders. 106, 21-37.

Pickett, J. 1978: Silurian conodonts from Blowclear and Liscombe Pools, New South Wales. J. Proc. roy. Soc. N.S.W. 111, 35-39.

Pollock, C. A., Rexroad, C. B. \& Nicoll, R. S. 1970: Silurian conodonts from northern Michigan and Ontario. J. Paleont. 44, 743-764.
Rexroad, C. B. 1967: Stratigraphy and conodont paleontology of the Brassfield (Silurian) in the Cincinnati Arch area. Bull. Indiana geol. Surv. 36, 64 pp.

Rexroad, C. B. \& Craig, W. W. 1971: Restudy of conodonts from the Bainbridge Formation (Silurian at Lithium, Missouri. J. Paleont. 45, 684-703.

Rexroad, C. B. \& Nicoll, R. S. 1971: Summary of conodont biostratigraphy of the Silurian system of North America. In Sweet, W. C. \& Bergström, S. (edit.) Symposium on Conodont Biostratigraphy. Mem. geol. Soc. Am. 127, 207-225.

Rexroad, C. B. \& Nicoll, R. S. 1972: Conodonts from the Estill Shale (Silurian, Kentucky and Ohio) and their bearing on multielement taxonomy. Geol. Palacont. Sonderbd 1, 57-74.

Rexroad, C. B., Noland, A. V. \& Pollock, C. A. 1978: Conodonts from the Louisville Limestone and the Wabash Formation (Silurian) in Clark County, Indiana and Jefferson County, Kentucky. Spec. Pap. Indiana geol. Surv. 16, 19 pp.

Rhodes, F. H. T. 1953: Some British Lower Palaeozoic conodont faunas. Phil. Trans. roy. Soc. B 237, 261-334.

Rhodes, F. H. T. \& Dineley, D. L. 1957: Devonian conodont faunas from South-west England. J. Paleont. 31, 353-369.

Richter, R. 1948: Einführung in die Zoologische Nomenclatur. Frankfurt a.m.: Kramer, 252 pp. (2nd edition).

Saied, W. A. A. 1979: Ordovician and Silurian coral faunas from northern Greenland. Unpublished M.Sc. thesis, University of Newcastle upon Tyne, England, $141 \mathrm{pp}$.

Saladzius, V. Yu. 1975: Conodonts of the Llandoverian (Lower Silurian) deposits of Lithuania. In Grigyalis, A. A. (edit.) Fauna in stratigrafiya paleozoya i Mesozoya Pribaltiki i Belorussii, 219-226. Vilna, USSR: Izd. Mintis.

Savage, N. M. 1985: Silurian (Llandovery-Wenlock) conodonts from the base of the Heceta Limestone, southeastern Alaska. Can. J. Earth. Sci. 22, 711-727.

Schönlaub, H. P. 1971: Zur Problematik der ConodontenChronologie an der Wende Ordoviz/Silur mit besonderer Berücksichtigung der Verhältnisse im Llandovery. Geol. Palacont. Sonderbd 5, 35-57.

Schönlaub, H. P. 1975a: Zum Alter der Radstädter Quarzphyllite (Unterostaplin, Salzburg). Annln Naturh. Mus. Wien 79, 47-55.

Schönlaub, H. P. 1975b: Conodonten aus dem Llandovery der Westkarawanken (Österreich). Verh. geol. Bundesanst. Wien 3, 45-65.

Schönlaub, H. P. 1980: Day 1 - Central Carnic Alps. Guidebook and abstracts for the Second European conodont symposium. Ecos II, Vienna-Prague, 35, 17-57.

Schönlaub, H. P. \& Zezula, G. 1975: Silur-Conodonten aus einer Phyllonitzone im Muralpen-Kristallin (Lungau-Salzburg). Verh. geol. Bundesanst. Wien 1975, 253-269.

Schopf, T. J. M. 1966: Conodonts of the Trenton Group (Ordovician) in New York, southern Ontario, and Quebec. $N$. Y. State Mus. Sci. Serv. Bull. 405, 105 pp.

Seddon, G. 1970: Frasnian conodonts from the Sadler Ridge Bugle Gap area, Canning basin, Western Australia. J. geol. Soc. Aust. 16, 723-753.

Seddon, G. \& Sweet, W. C. 1971: An ecologic model for conodonts. J. Paleont. 45, 869-880. 
Serpagli, E. 1967: Conodonti dell Ordoviciano superiore (Ashgilliano) delle Alpi Carniche. Bull. Soc. Paleont. Italiano 6, 30-111.

Serpagli, E. 1970: Uppermost Wenlockian - Upper Ludlovian (Silurian) conodonts from western Sardinia. Bull. Soc. Paleont. Italiano 9, 67-96.

Serpagli, E. \& Greco, A. 1964: Observazioni preliminari zu alami Conondonti Ordoviciani e Siluriani delle Alpi Carniche Italiane. Bull. Soc. Paleont. Italiano 3, 192-211.

Smith. M. P. 1985: Ibexian-Whiterockian (Ordovician) conodont palaeontology of East and eastern North Greenland. Unpublished Ph.D. thesis, University Nottingham. 372 pp.

Smith, M. P. \& Peel, J. S. 1986: The age of the Danmarks Fjord Member, eastern North Greenland. Rapp. Grønlands geol. Unders. 132, 7-13.

Smith, M. P., Sønderholm, M. \& Tull, S. 1989: The Morris Bugt Group (Middle Ordovician - early Silurian) of North Greenland and its correlatives. Rapp. Grønlands geol. Unders. 143,

Sønderholm, M. \& Harland, T. L. The late Ordovician Silurian carbonate shelf in North Greenland: depositional evolution and lithostratigraphy of the upper Morris Bugt Group and the Washington Land Group. Unpublished manuscript.

Sønderholm, M., Harland, T. L., Due, P. H., Jørgensen, L. N. \& Peel, J. S. 1987: Lithostratigraphy and depositional history of Upper Ordovician - Silurian shelf carbonates in central and western North Greenland. Rapp. Grønlands geol. Unders. 133, 27-40.

Sparling, D. R. 1981: Middle Devonian conodont apparatuses with seven types of elements. J. Paleont. 55, 295-316.

Spasov, H. 1966: [Significance of the conodont fauna for the stratigraphy of the Palaeozoic.] Izv. Bulg. Akad. Nauk. Geol. Inst. 15, 89-97 (in Bulgarian).

Spasov, H. \& Filipović, I. 1966: [The conodont fauna of the older and younger Paleozoic in southeastern and northwestern Bosnia.] Geoloski Glasn., Saraj. 2, 33-53 (in Slovac).

Spjeldnæs, N. 1961: Ordovician climatic zones. Norsk geol. Tidsskr. 41, 45-77.

Stauffer, C. R. 1930: Conodonts from the Decorah Shale. J. Paleont. 2, 121-128.

Stauffer, C. R. 1935a: Conodonts from the Glenwood Beds. Bull. geol. Soc. Am. 46, 125-168.

Stauffer, C. R. 1935b: The conodont fauna of the Decorah Shale (Ordovician). J. Paleont. 9, 596-620.

Stauffer, C. R. 1940: Conodonts from the Devonian and associated clays of Minnesota. J. Paleont. 14, 417-435.

Stone, G. L. \& Furnish, W. M. 1959: Bighorn conodonts from Wyoming. J. Paleont. 33, 211-228.

Stouge, S. 1977: A lower Ordovician conodont fauna from the Cape Clay Formation, N. W. Greenland. Abstr. geol. Soc. Amer. 9, 656 only.

Stouge, S. 1978: Upper Canadian (Lower Ordovician) conodonts from central East-Greenland. Abstr. geol. Soc. Amer. 10, 499 only.

Stouge, S. \& Peel, J. S. 1979: Ordovician conodonts from the Precambrian shield of southern West Greenland. Rapp. Grønlands geol. Unders. 91, 105-109.
Stouge, S. \& Stouge, G. B. 1985: An Upper Llandovery conodont fauna from eastern Hall Land. Bull. Soc. Paleont. Ital. 23, 103-112.

Stouge, S., Stouge, G. B. \& Albani, R. 1985: Lower Ordovician conodonts from Washington Land, western North Greenland. Bull. geol. Soc. Denm. 33, 261-272.

Sweet, W. C. 1979: Late Ordovician conodonts and biostratigraphy of the western Midcontinent Province. Brigham Young Univ. Geol. Stud. 26, 45-86.

Sweet. W. C. 1981a: Genus Aphelognathus Branson, Mehl \& Branson, 1951 In Ziegler, W. (edit.) Catalogue of conodonts, IV, 27-56. Stuttgart: E. Schweizerbartsche Verlagsbuchhandlung (Nägele u. Obermüller).

Sweet, W. C. 1981b: Morphology and composition of elements - macromorphology of elements and apparatuses. In Robison, R. A. (edit.) Treatise on Invertebrate Paleontology. W (Supplement 2, Conodonta), W17-20. Geol. Soc. Am., Univ. Kansas Press.

Sweet, W. C. 1981c: Genus Pseudobelodina Sweet, 1979. In Ziegler, W (edit.) Catalogue of Conodonts IV, 325-353. Stuttgart: E. Schweizerbartsche Verlagsbuchhandlung (Nägele u. Obermüller).

Sweet, W. C. \& Bergström, S. M. 1971: The American Upper Ordovician Standard III. A revised time-stratigraphic classification of North American upper Middle and Upper Ordovician rocks. Bull. geol. Soc. Am. 82, 613-628.

Sweet, W. C. \& Schönlaub, H. P. 1975: Conodonts of the genus Oulodus Branson \& Mehl, 1933. Geol. Palaont. Sonderbd 9, 41-59.

Sweet, W. C., Ethington, R. L. \& Barnes, C. R. 1971: North American Middle and Upper Ordovician conodont faunas. Mem. geol. Soc. Am. 127, 163-193.

Sweet, W. C., Thompson, T. L. \& Satterfield, I. R. 1975: Conodont stratigraphy of the Cape Limestone (Maysvillian) of eastern Missouri. Rep. Invest. Mo. geol. Surv. 57, 1-59.

Thompson, T. L. \& Satterfield, I. R. 1975: Stratigraphy and conodont biostratigraphy of strata contiguous to the Ordovician-Silurian boundary in eastern Missouri. Rep. Invest. Mo. geol. Surv. 57, 61-108.

Tipnis, R. S. \& Cecile, M. P. 1980: Early Paleozoic conodont biostratigraphy and paleogeography of Northwestern Canada. Bull. Am. Ass. Petrol. Geol. 64, 793 only.

Uyeno, T. T. 1974: Correlations and identifications of fossils, Silurian to Devonian assemblages (conodonts). Pap. geol. Surv. Can. 74-11, 24-26.

Uyeno, T. T. \& Barnes, C. R. 1981: A summary of Lower Silurian conodont biostratigraphy of the Jupiter and Chicotte Formations, Anticosti Island, Quebec. In Lesprance, P. J. (edit.) Subcommission of Silurian Stratigraphy, Ordovician-Silurian Boundary. Field Meeting, Anticosti-Gaspé, Québec 1981, Vol. II: Stratigraphy and Paleontology, 173184.

Uyeno, T. T. \& Barnes, C. R. 1983: Conodonts of the Jupiter and Chicotte Formations (Lower Silurian) Anticosti Island, Quebec. Bull. geol. Surv. Can. 355, 49 pp.

Valentine, J. W. 1973: Evolutionary paleoecology of the marine biosphere. New Jersey: Pentrice-Hall, 511 pp. 
Viira, V. 1977: [The composition and distribution of the conodonts in the Silurian of the Baltic region.] In Kalfe, D. (edit.) [The facies and fauna of the Baltic Silurian], 179-192. Akad. Sci. Estonian SSSR, Inst. Geol. (in Estonian).

Walliser, O. H. 1957: Conodonten aus dem oberen Gotlandium Deutschlands und der Karnischen Alpen. Notizbl. Hess. Landesamt. Boden Forch. 85, 28-52.

Walliser, O. H. 1962: Conodont Chronologie des Silurs (Gotlandium) und des tieferen Devons mit besonderer Berücksichtigung der Formations Grenze. Symposium Silur/Devon Grenze, Bonn-Bruxelles (1960), 281-287.
Walliser, O. H. 1964: Conodonten des Silurs. Abh. hess. geol. Landesamt Bodenforsch 41, 106 pp.

Walliser, O. H. 1971: Conodont biostratigraphy of the Silurian of Europe. Mem. geol. Soc. Am. 127, 195-260.

Walliser, O. H. 1972: Conodont apparatuses in the Silurian. Geol. Palaont. Sonderbd 1, 75-80.

Wang Cheng-Yan 1980: Silurian conodonts from the Qujing District, Yunnan. Acta palaeont. sin. 19(5), 369-378.

Wang Cheng-Yan \& Ziegler, W. 1983: Conodonten aus Tibet. Neues Jb. Geol. Paläont. Mh. 1983(2), 69-79. 


\section{APPENDIX}

Numerical abundance of conodont elements in GGU collections. Principal sections are illustrated in figs 1-21.

Table 1. Central Peary Land

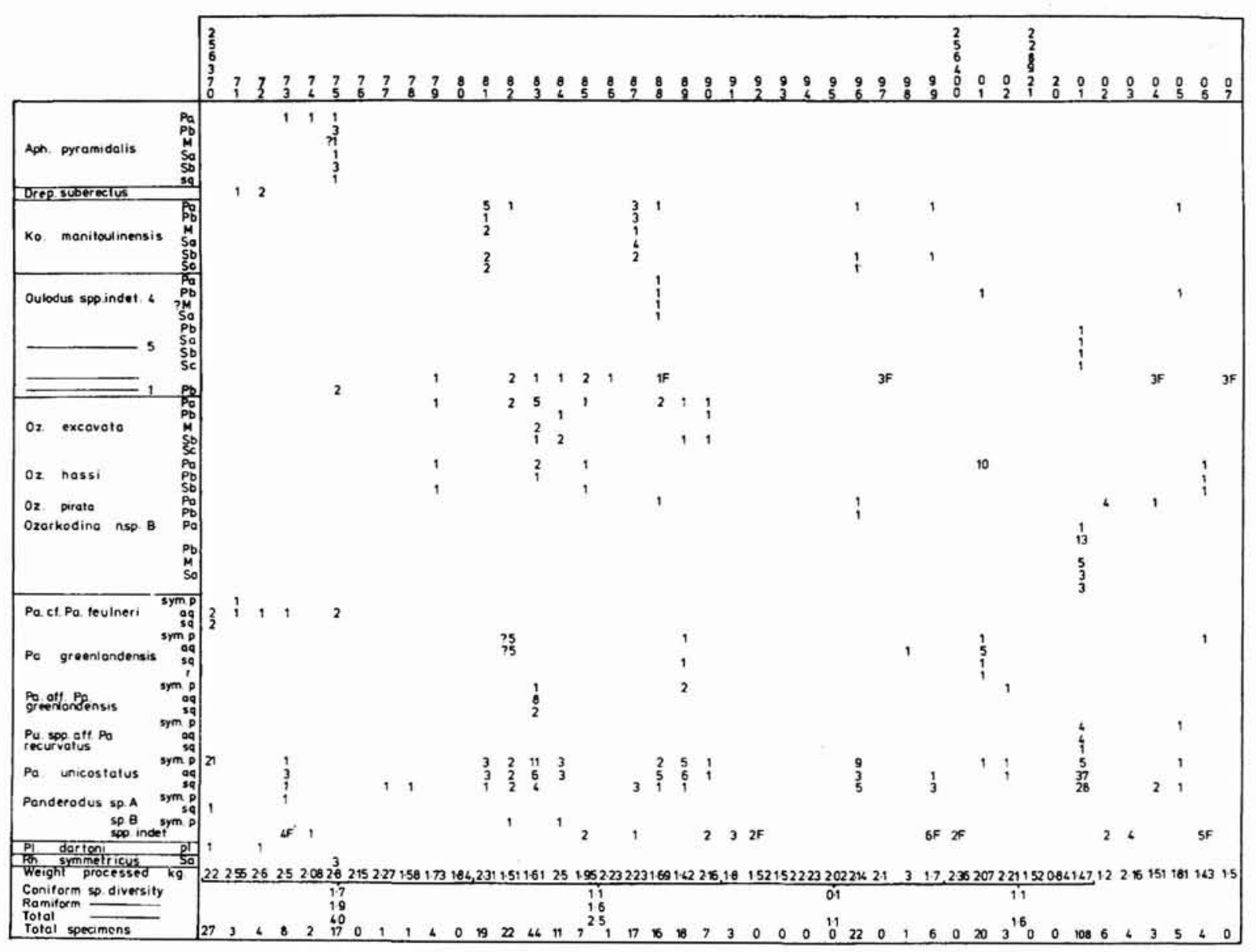


Table 1 cont.

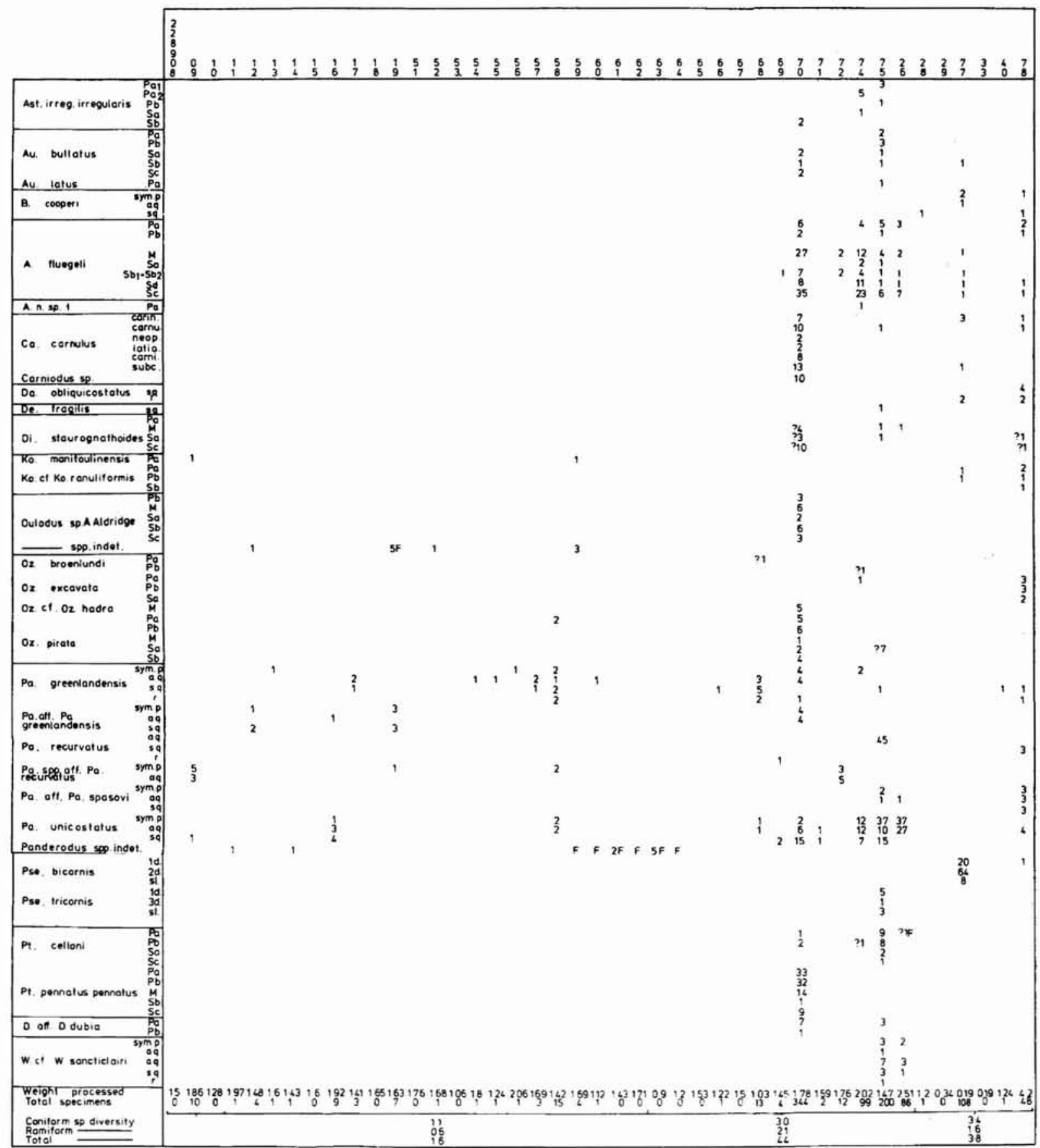


Table 2. Eastern Peary Land

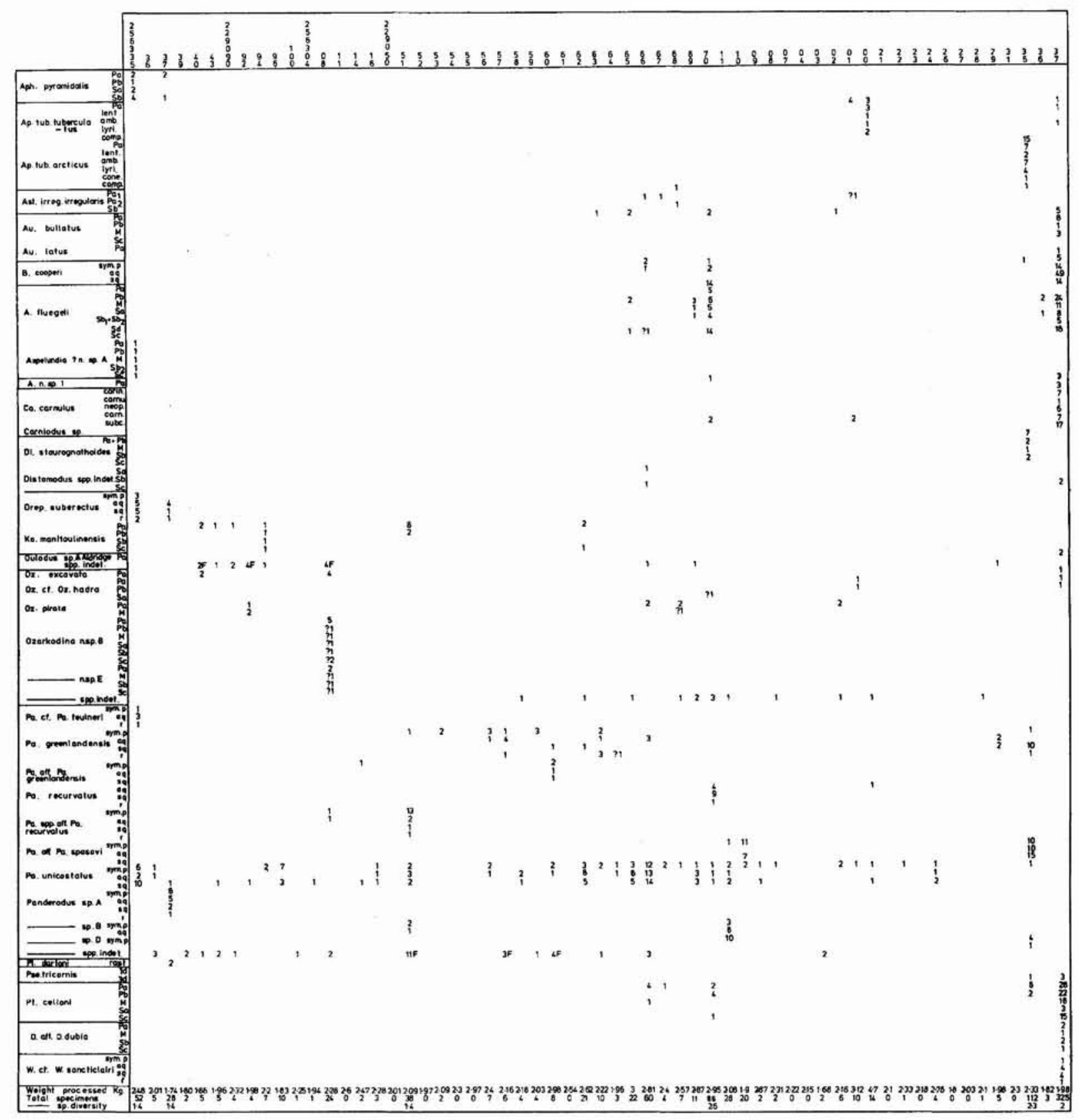


Table 3. Central and eastern North Greenland spot samples

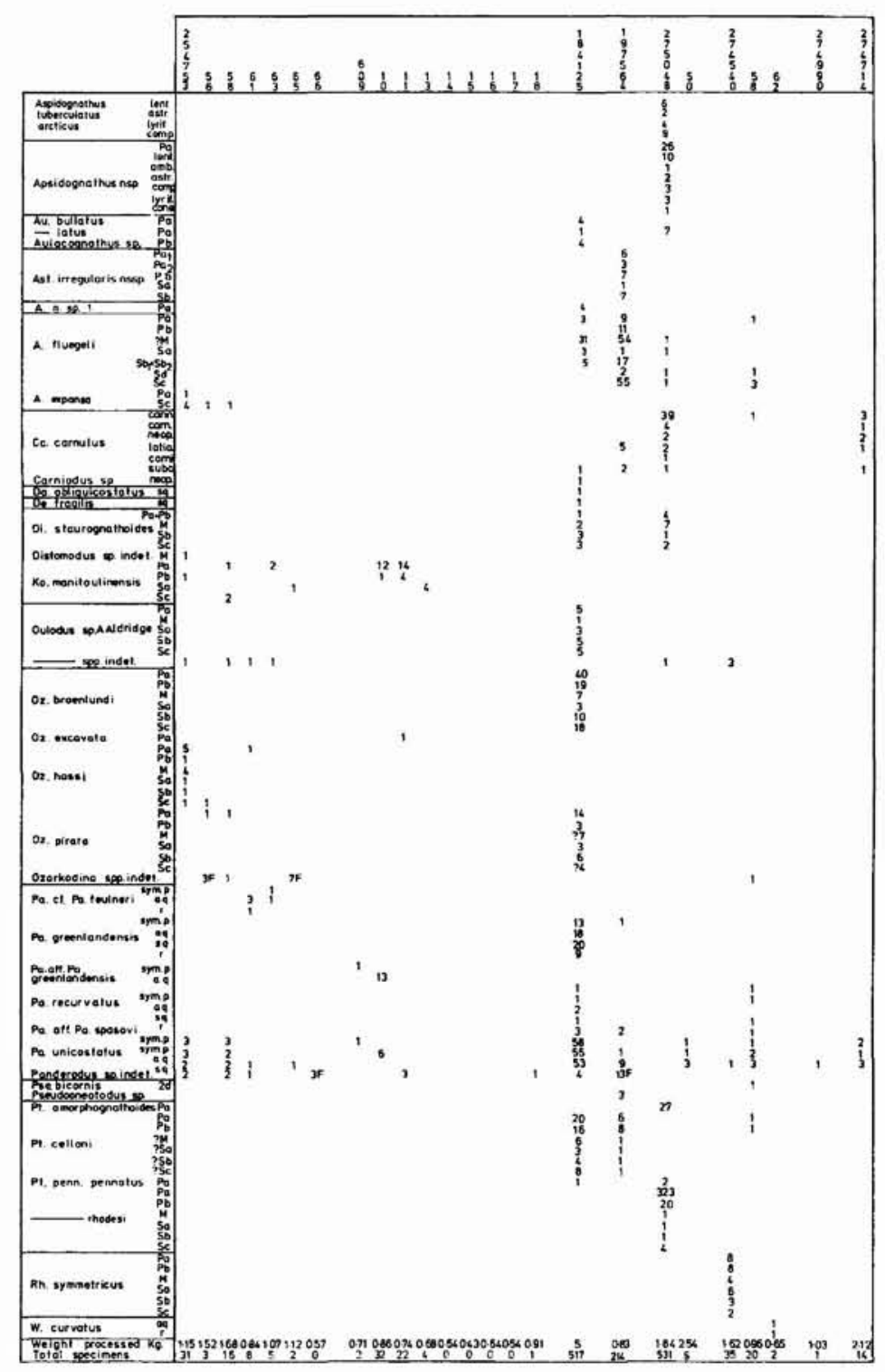

Central and eastern North Greenland spot samples. GGU 254753-66, Tures $ø$ Formation, Odin Fjord; samples from JMH 780714-1 (fig. 3) but below the lowest sample in this section illustrated in fig. 10. GGU 254781, 254609-18, Odins Fjord Formation, Odins Fjord; the former sample is from section height $55 \mathrm{~m}$ in JMH 780414-1 (figs 3, 10) while the latter sequence occurs from section heights 180-270 $\mathrm{m}$ in the same section. GGU 184125, Odins Fjord Formation, Børglum Elv (Aldridge, 1979; collected by J. S. Peel in 1974 from the area of JEM 790804 in fig. 3). GGU 197564, Odins Fjord Formation, G. B. Schley Fjord (Christie \& Ineson, 1979; see fig. 3). GGU 275048, Lauge Koch Land Formation, Profilfjeldet Member, Valdemar Glüchstadt Land (fig. 4). GGU 275050, Samuelsen Høj Formation, Valdemar Glückstadt Land (fig. 4). GGU 274540, Turesø Formation, Kronprins Christian Land (fig. 4). GGU 274558, 274562, Lauge Koch Land Formation, Profilfjeldet Member, Kronprins Christian Land (fig. 4). GGU 274990, Samuelsen Høj Formation, Kronprins Christian Land (fig. 4). GGU 274714, Odins Fjord Formation, Kronprins Christian Land (fig. 4). 
Table 4. Odin Fjord, Peary Land

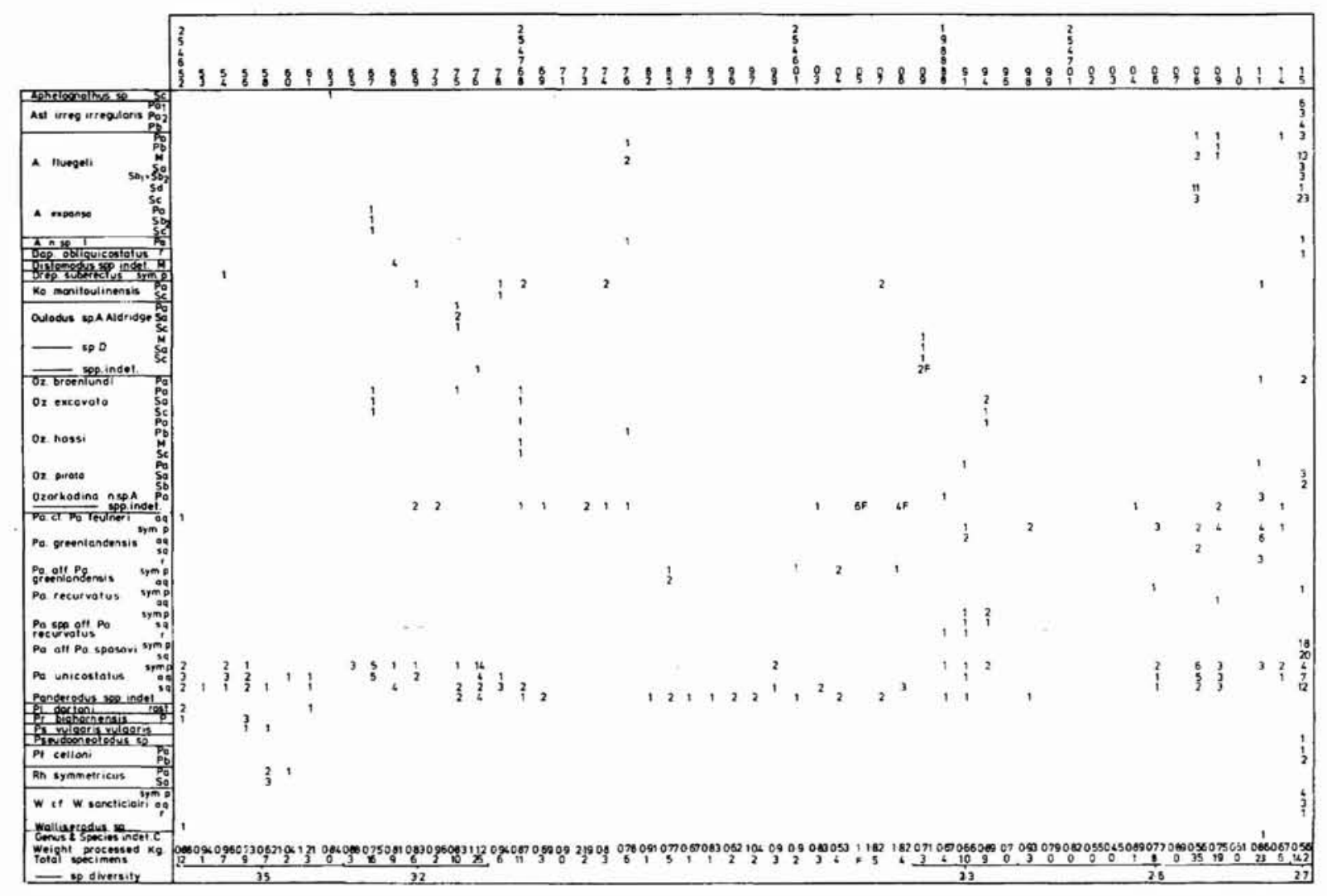


Table 5. Kronprins Christian Land

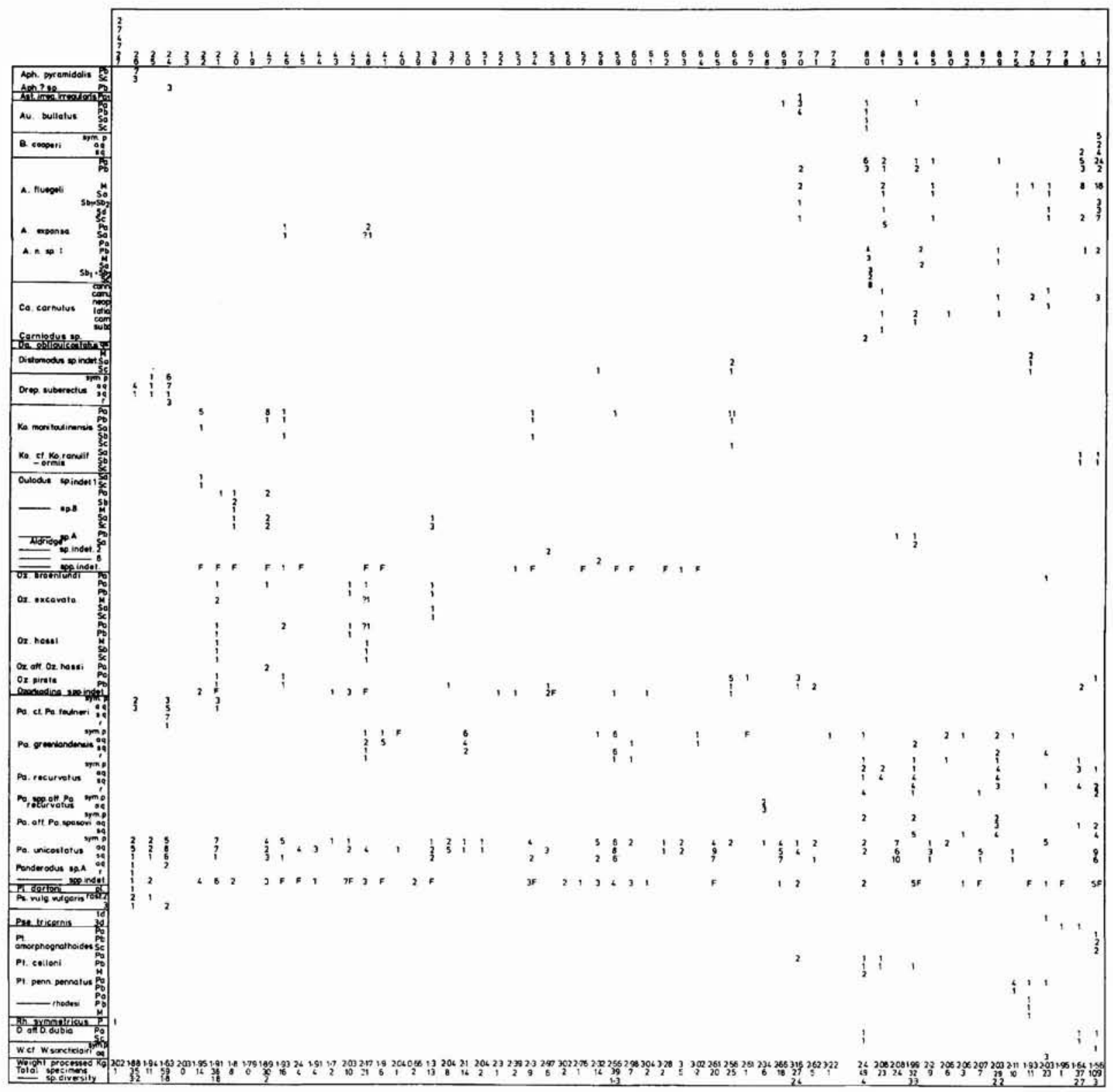


Table 6. J. P. Koch Fjord, Peary Land

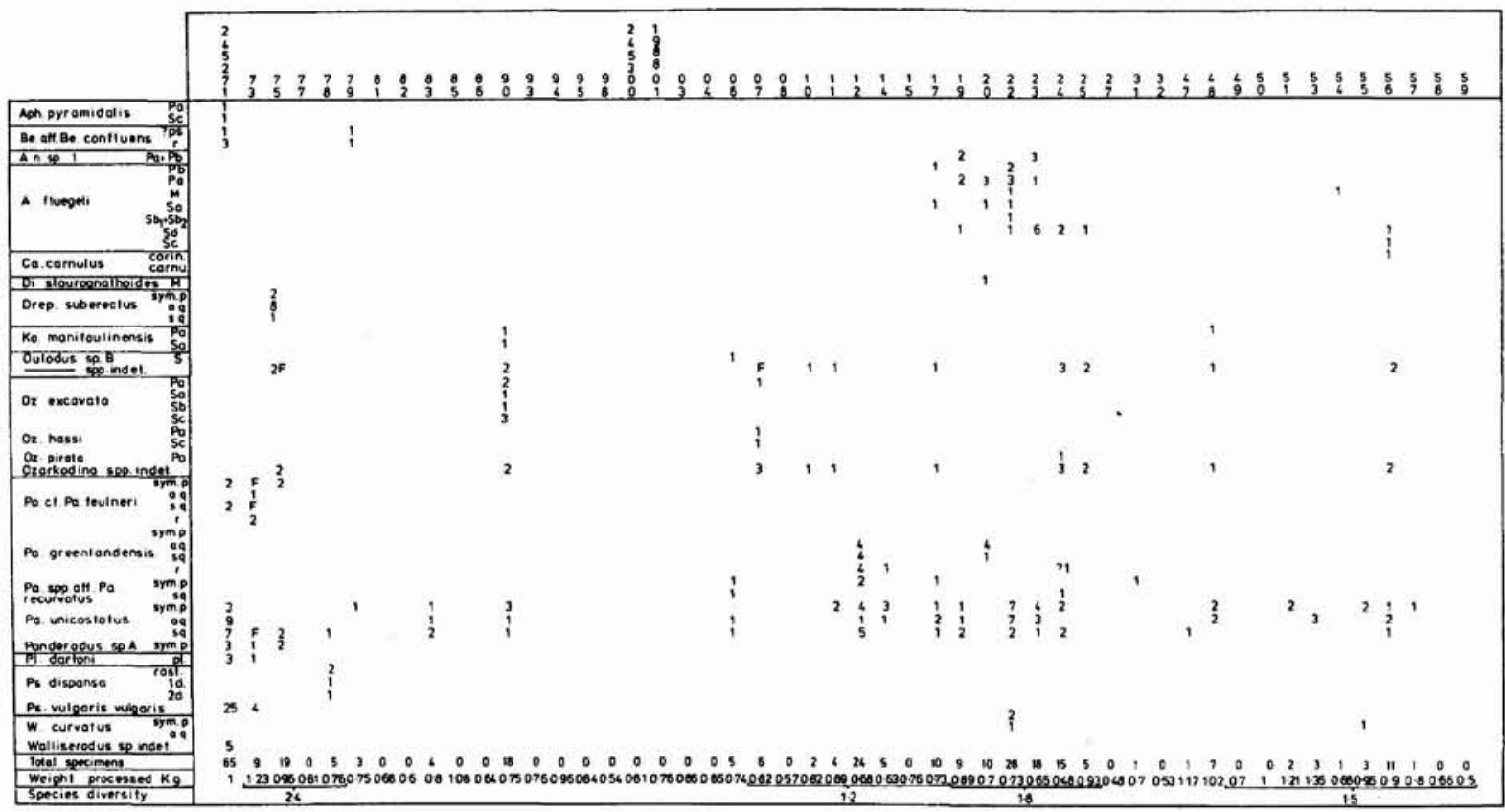

Table 7. Wulff Land

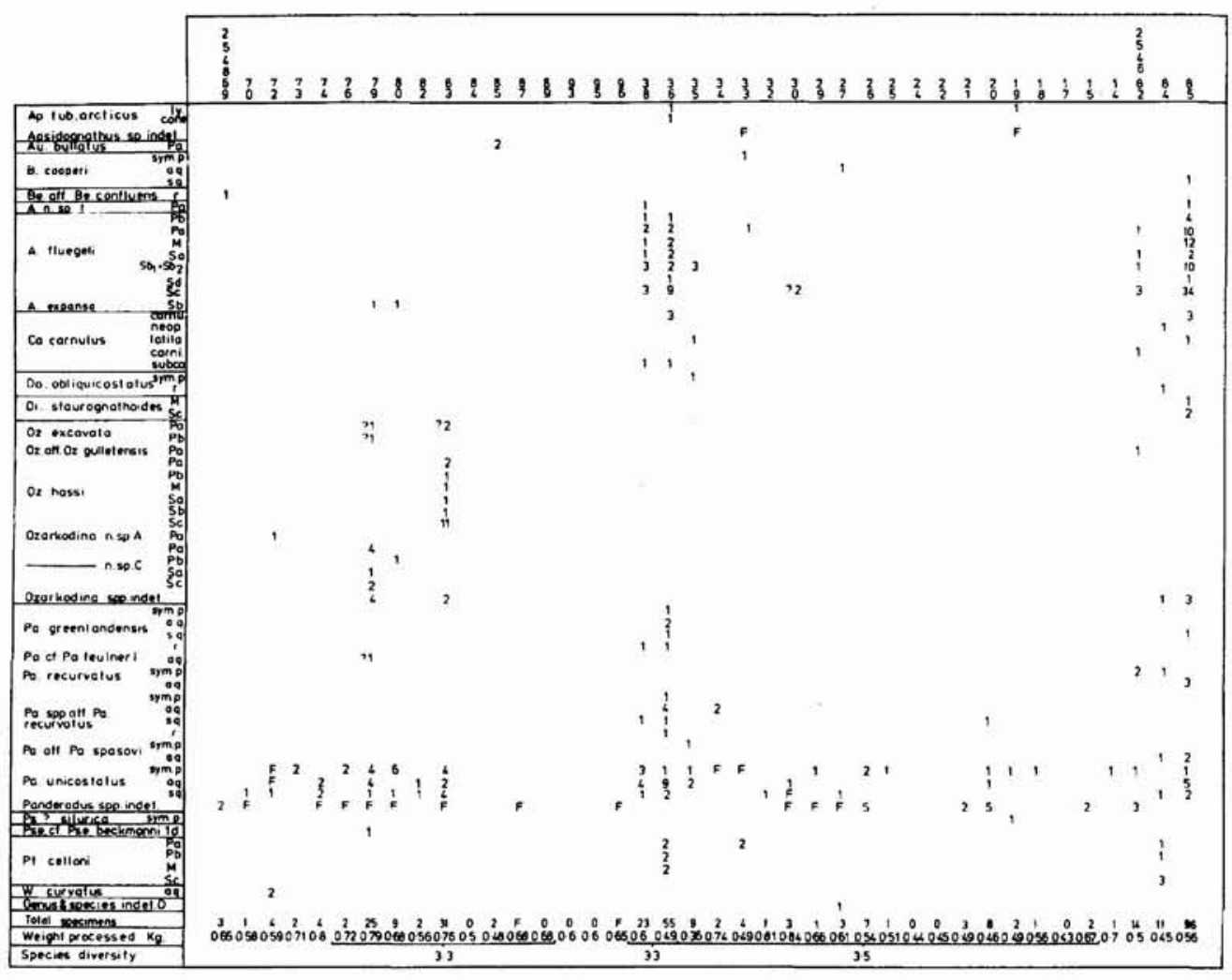

Table 8. Washington Land, localities 1-5, 8-10 


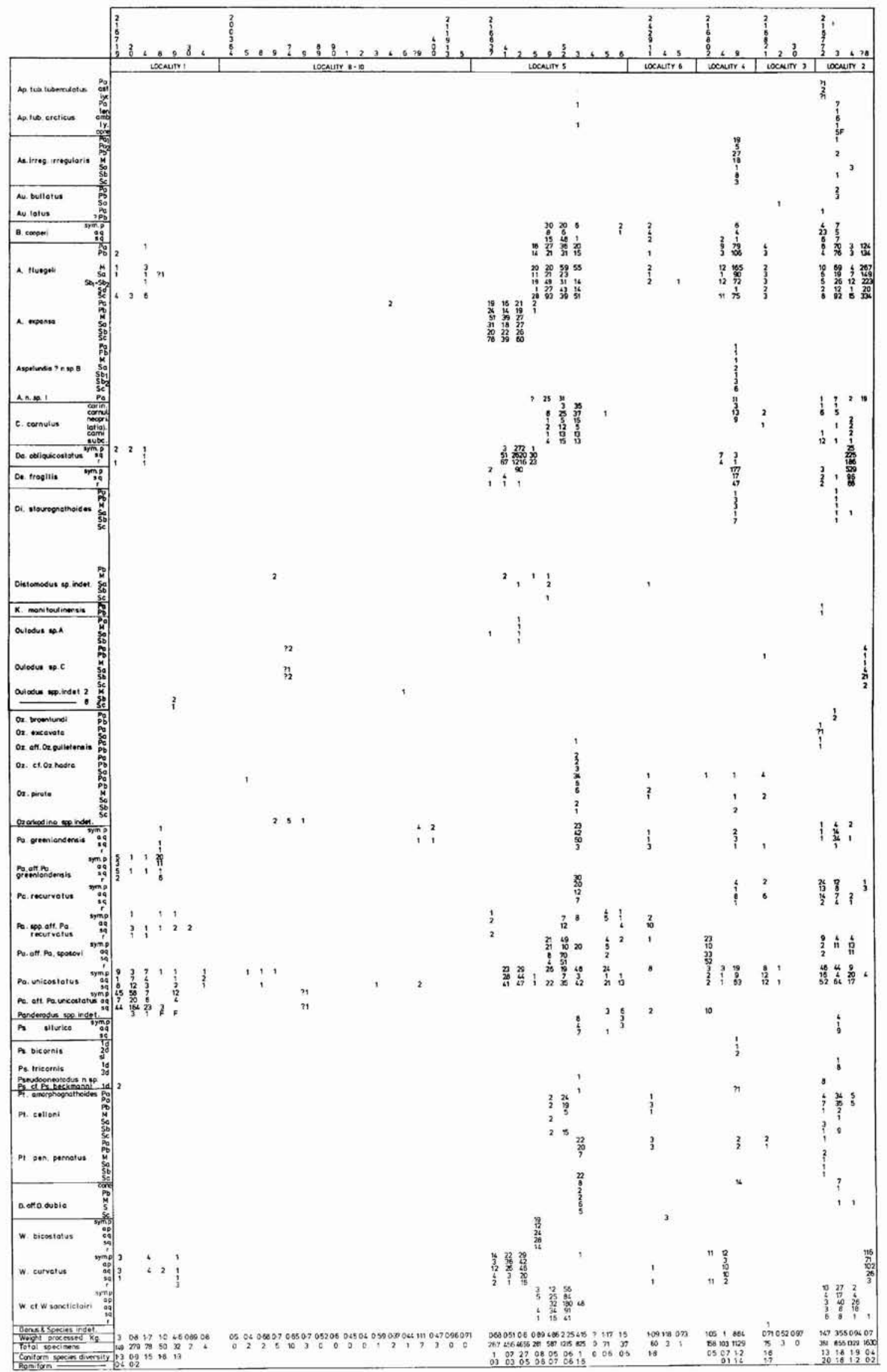


Table 9. Washington Land, localities 11-13

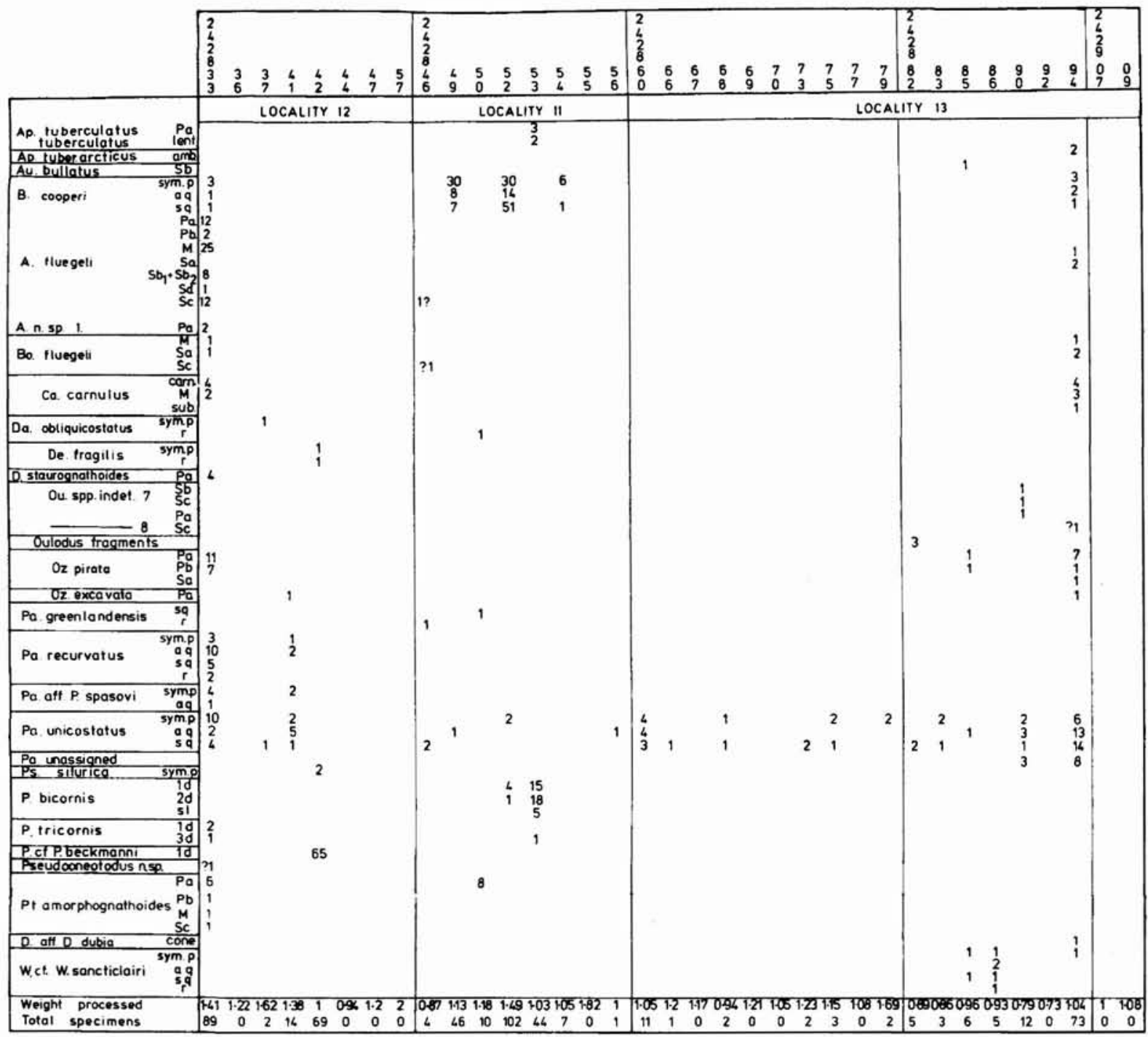


Table 10. Western North Greenland spot samples

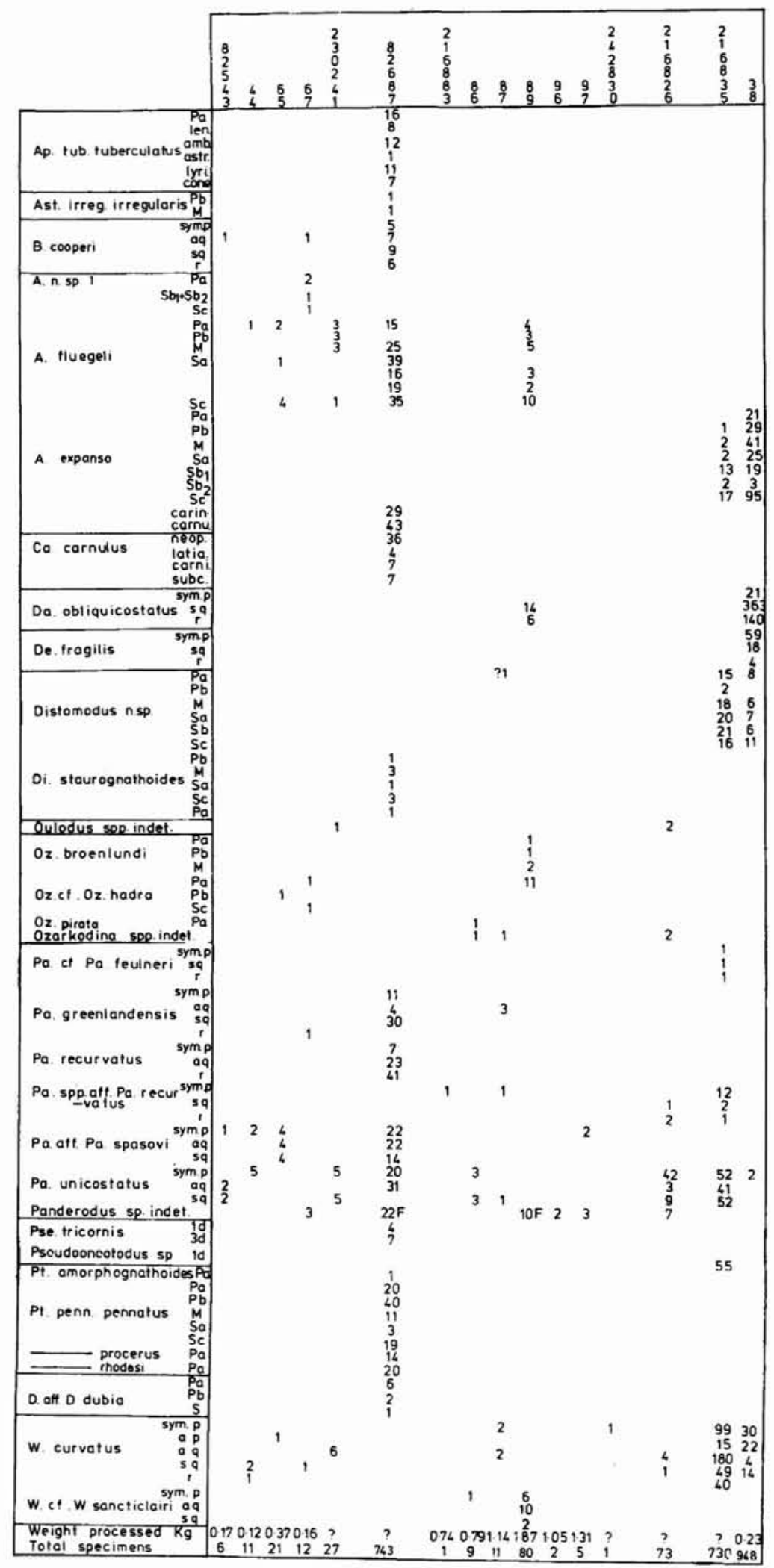

Western North Greenland spot samples. Washington Land unless stated. GGU $82543,82544,82565,82567$, Hauge Bjerge Formation, 'Sunmark Mountain', Hall Land (fig. 2). GGU 82687, 230249 Hauge Bjerge Formation, Kayser Bjerg, Hall Land (fig. 2). GGU, Hall Land. $216883,216886,216887,216889$, upper Aleqatsiaq Fjord Formation, Kap Schuchert. 216896, 216897, Lafayette Bugt Formation (?), Kap Schuchert, (cf. Hurst, 1980b, p. 82). 242830, near top of Aleqatsiaq Fjord Formation, Aleqatsiaq Fjord. 216826, upper Aleqatsiaq Fjord Formation (?), Kap Constitution. 216835, Aleqatsiaq Fjord Formation or Cape Schuchert Formation, Kap Schuchert. 216838, Cape Schuchert Formation, Kap Schuchert. 